\title{
De controle over de politie in Engeland en Wales
}

Citation for published version (APA):

Royakkers, C. H. M. (1997). De controle over de politie in Engeland en Wales. [Doctoral Thesis, Maastricht University]. Gouda Quint. https://doi.org/10.26481/dis.19970307cr

Document status and date:

Published: 01/01/1997

DOI:

$10.26481 /$ dis. $19970307 \mathrm{cr}$

Document Version:

Publisher's PDF, also known as Version of record

\section{Please check the document version of this publication:}

- A submitted manuscript is the version of the article upon submission and before peer-review. There can be important differences between the submitted version and the official published version of record.

People interested in the research are advised to contact the author for the final version of the publication, or visit the DOI to the publisher's website.

- The final author version and the galley proof are versions of the publication after peer review.

- The final published version features the final layout of the paper including the volume, issue and page numbers.

Link to publication

\footnotetext{
General rights rights.

- You may freely distribute the URL identifying the publication in the public portal. please follow below link for the End User Agreement:

www.umlib.nl/taverne-license

Take down policy

If you believe that this document breaches copyright please contact us at:

repository@maastrichtuniversity.nl

providing details and we will investigate your claim.
}

Copyright and moral rights for the publications made accessible in the public portal are retained by the authors and/or other copyright owners and it is a condition of accessing publications that users recognise and abide by the legal requirements associated with these

- Users may download and print one copy of any publication from the public portal for the purpose of private study or research.

- You may not further distribute the material or use it for any profit-making activity or commercial gain

If the publication is distributed under the terms of Article $25 \mathrm{fa}$ of the Dutch Copyright Act, indicated by the "Taverne" license above, 
De controle over de politie in Engeland en Wales 
Met dank aan de bibliotheek van het Politiestudiecentrum te Warnsveld

Ter nagedachtenis aan mijn moeder Aan mijn vader, Réjean, Hans en Marianne 


\section{De controle over de politie in Engeland en Wales}

\section{PROEFSCHRIFT}

ter verkrijging van de graad van doctor aan de Universiteit Maastricht,

op gezag van de Rector Magnificus, Prof. mr M.J. Cohen, volgens het besluit van het College van Decanen,

in het openbaar te verdedigen

op vrijdag 7 maart 1997

om 14.00 uur

door

Cornelia Henrica Maria Royakkers 
Promotores:

Prof. dr G.A.A.J van den Heuvel

Prof. dr M.E. Punch (voormalig hoogleraar Universiteit Nijenrode)

Beoordelingscommissie:

Prof. mr G.P.M.F. Mols (voorzitter)

Prof. mr J. Naeyé (Vrije Universiteit Amsterdam)

Prof. mr Th.A. de Roos 


\section{Inhoudsopgave}

Gebruikte afkortingen $\ldots \ldots \ldots \ldots \ldots \ldots \ldots$ XI

1 Inleiding $\ldots \ldots \ldots \ldots \ldots \ldots \ldots \ldots \ldots \ldots$

1.1 Who polices the police? . . . . . . . . . . . . 1

1.2 Probleemstelling: De onafhankelijkheid van de politie ... . 3

1.3 De politie en de maatschappij . . . . . . . . . . . . 4

1.4 De theorie van Wilson ................ . . 5

1.5 De theorie van Gardiner . . . . . . . . . . . . 8

1.6 De theorie van Sherman ............... . . . 9

1.6.1 Schandalen en hervormingen .......... . 9

1.6.2 Definitie schandaal . . . . . . . . . . . 10

1.6.3 Het onthullen van een schandaal . . . . . . . 11

1.6.4 Reageren op een schandaal . . . . . . . . 12

1.6.4.1 Reacties van agenten . . . . . . . . . 12

1.6.4.2 Reacties van de top van de politie op korte termijn ............... 13

1.6.4.3 Reacties in het beleid op lange termijn . . 15

1.6.4.4 Het verdere verloop van een schandaal ... 16

1.7 Doelstelling en methoden van onderzoek . . . . . 17

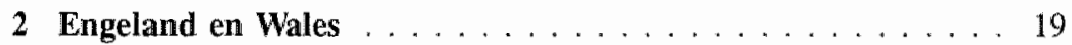

2.1 Inleiding . . . . . . . . . . . . . . . . 19

2.2 Politie, gezag en onafhankelijkheid . . . . . . . . . 19

2.3 Common law - continental law . . . . . . . . . 20

2.3 .1 Damaška . . . . . . . . . . . . . . 23

2.3.2 De systemen in Nederland en Engeland en Wales . . 23

2.3.3 De politie in Engeland en Wales ... . . . . . . 24

2.3 .4 Geschiedenis ................. . . 26

2.3 .5 Afronding ................. . . 26

2.4 Is de theorie van Sherman toepasbaar op de politie in

Engeland en Wales? . . . . . . . . . . . . . . 26

2.5 Vijf casus . . . . . . . . . . . . . . . . . . . . . 29

2.5 .1 Vertrouwen . . . . . . . . . . . . . 29 29

2.5 .2 Klachten ................. . . 30

2.5.3 Verantwoording en methode .......... 30

2.5.4 Vijf schandalen . . . . . . . . . . . 31

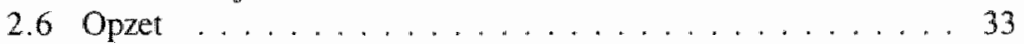

3 Geschiedenis van de Engelse politie tot $1960 \ldots \ldots \ldots$

3.1 De 19 de eeuw . . . . . . . . . . . . . . . . . 35

3.2 De eeuwwisseling ................. 39

3.3 De periode rond en na de Eerste Wereldoorlog . . . . . . 40

3.4 De Tweede Wereldoorlog ............... 44 
3.5 De periode na de oorlog . . . . . . . . . 45

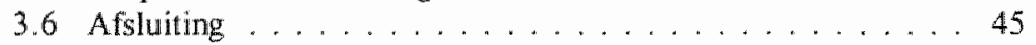

4 Het politiekorps in zijn huidige vorm . . . . . . . 47

4.1 Inleiding . . . . . . . . . . . . . 47

4.2 Structuur en functies . . . . . . . . . . . . 47

4.3 Interne structuur van de Metropolitan Police . . . . . . . 48

4.4 Overige politiediensten . . . . . . . . . . . . . . . 49

4.5 Bevoegdheden . . . . . . . . . . . . . . . 50

4.6 De politie en de lokale overheid . . . . . . . . . . 51

4.7 Discretionair optreden $\ldots \ldots \ldots \ldots \ldots \ldots \ldots$

4.7 .1 Inleiding $\ldots \ldots \ldots \ldots \ldots \ldots . \ldots . \ldots 54$

4.7.2 Fisher v. Oldham Corporation (1930) $2 \mathrm{~KB} 364 \ldots 55$

4.7.3 R v. Met. Police Comr., ex p. Blackburn (1968) 2 QB 118, (1968) 1 All ER $763 \ldots \ldots$...... 56

4.7.4 R v. Metropolitan Police Comr, ex p. Blackburn (1973) QB 241, (1973) 1 All ER $324 \ldots \ldots . .57$

4.8 De inspecteurs van het Home Office . . . . . . . . . 58

4.9 Richtlijnen van het ministerie . . . . . . . . . . . 60

4.9 .1 Inhoud van de circulaires . . . . . . . . . 60

4.10 Afronding: verantwoording . . . . . . . . 63

5 Causes célèbres: the Royal Commission on the Police . . . . 65

5.1 Inleiding . . . . . . . . . . . . . . . 65

5.2 Incidenten . . . . . . . . . . . . . . . . . . 65

5.3 Reactie van het parlement . . . . . . . . . . . . 66

5.4 Instelling van een Commissie . . . . . . . . . . 6.8

5.5 Het eindrapport van de Royal Commission . . . . . . . . 69

5.5.1 Een nationaal politiekorps? . . . . . . . . 70

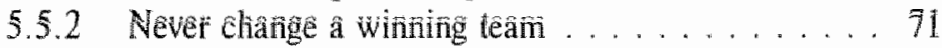

5.5 .3 Klachten .................. 71

5.5.4 Memorandum of Dissent . . . . . . . . . . 72

5.6 'Every country in the world envies us our police' . . . . . 73

5.6 .1 Het parlement . . . . . . . . . . . 74

5.7 Het wetsontwerp . . . . . . . . . . . . . 76

5.8 Police Act $1964 \ldots \ldots \ldots \ldots \ldots \ldots \ldots \ldots . \ldots \ldots$

5.8 .1 Minister . . . . . . . . . . . . . . . . 76

5.8 .2 Parlement . . . . . . . . . . . . . . 77

5.8 .3 Klachten . . . . . . . . . . . . . . . 78

5.9 Conclusie . . . . . . . . . . . . . . . 78

6 Klachten over politieoptreden: de dood van Blair Peach ... 81

6.1 Inleiding . . . . . . . . . . . . 81

6.2 De procedure in de Police Acts van 1964 en $1976 \ldots \ldots .81$ 
6.3 "Is not the fact that police investigate police an inherent weakness in the scheme?" .............. 83

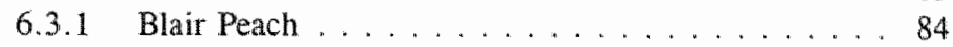

6.3 .2 Het Lagerhuis . . . . . . . . . . . . . . 85

6.3 .3 Het Scarman-rapport . . . . . . . . . . . . 86

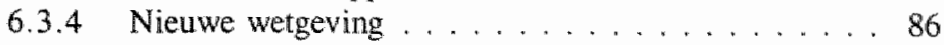

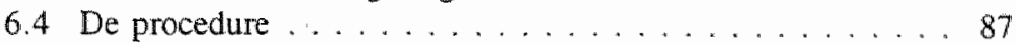

6.4 .1 Informele afdoening . . . . . . . . . . 88

6.4 .2 De standaard procedure ........... 89

6.4 .3 Police Complaints Authority ............ 89

6.4 .4 Toezicht van de PCA ..................... 91

6.4 .5 Strafrecht of een disciplinaire matregel ...... 92

6.4 .6 Aanpassing van het systeem? . . . . . . . . . . 94

6.4.7 De effectiviteit van de klachtenprocedure . . . . . . 99 95

6.5 Conclusie ........................... 97

7 De rellen in Brixton . . . . . . . . . . . . . . . . . 99

7.1 Inleiding . . . . . . . . . . . . . . . . . . . . 99

7.2 De achtergrond van de Brixton rellen . . . . . . . . . 99

7.3 De gebeurtenissen op 10-12 april 1981 . . . . . . . 100

7.4 Het Parlement ... . . . . . . . . . . . . . . . . . . 100

7.5 Het Scarman-rapport ... . . . . . . . . . . . . . . . 101

7.6 Bespreking van het rapport van Scarman ......... 103

7.7 Acceptance of the Report: The House could not have looked for firmer guidance of intent . . . . . . . . . . . . . 104

7.8 Het verdere verloop . . . . . . . . . . . . . . . . 104

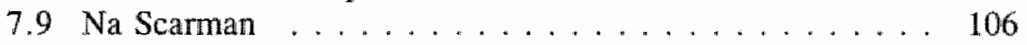

7.10 De staking van $1984 \ldots \ldots \ldots \ldots . \ldots \ldots$

7.11 Rellen in Brixton . . . . . . . . . . . . . . . . 109

7.12 Conclusie . . . . . . . . . . . . . 110

8 Crown Prosecution Service: het Fisher rapport . . . . . . . 113

8.1 De Confait-case ................... 113

8.2 Het rapport van de Royal Commission ........... 115

8.3 Prosecution of Offences Act $1985 \ldots \ldots \ldots 118$

8.4 Taken van de CPS . . . . . . . . . . . . . . . 118

8.4.1 Taken van de DPP .............. 119

8.4.2 Bevoegdheden van de prosecutors ......... 119

8.5 De situatie vóór de Prosecution of Offences Act 1985 . . 120

8.6 Opportuniteitsbeginsel . . . . . . . . . . . . . . . 123

8.7 Een onafhankelijke Crown Prosecution Service? . . . . . 123

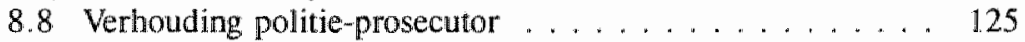

8.9 Controle over de politie . . . . . . . . . . . . . . 127 
9 Miscarriages of justice . . . . . . . . . . . . . . . . . 129

9.1 Inleiding . . . . . . . . . . . . . . . . . . . . . . . . 129

9.2 De lerse zaken . . . . . . . . . . . . . . . 131

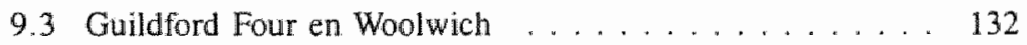

9.3.1 De veroordeling ................ 132

9.3 .2 De vrijlating ............... 133

9.3.3 De zaak tegen de drie agenten . . . . . . . . . 134

9.4 Maguire Seven . . . . . . . . . . . . . . . . . . 136

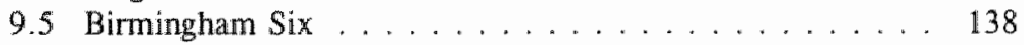

9.6 Judith Ward . . . . . . . . . . . . . . . . . . . 140

9.7 Miscarriages of justice . . . . . . . . . . . . . . 142

9.8 Remedie tegen miscarriages of justice . . . . . . . . 143

9.9 Problemen in de zaken . . . . . . . . . . . . . . . . . 144

9.9 .1 Rechterlijke macht . . . . . . . . . . . . . . 144

9.9.2 De beroepsprocedure . . . . . . . . . . . . 145

9.9.3 Een gematigd inquisitoir strafproces? . . . . . . 146

9.9 .4 Poilitie . . . . . . . . . . . . . . . . . . 147

9.10 Het parlement . . . . . . . . . . . . . 150

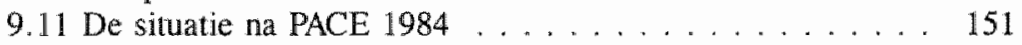

9.11 .1 Inleiding . . . . . . . . . . . . . . 151

9.11 .2 De Miller-zaak . . . . . . . . . . . . . . . 153

9.11 .3 Police Constable Tony Salt . . . . . . . . . . . 153

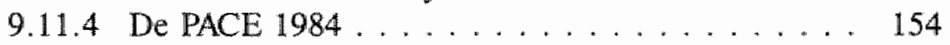

9.12 Een Royal Commission? . . . . . . . . . . . . . 155

9.13 The Royal Commission on Criminal Justice . . . . . . . 158

9.13.1 Doelstelling . . . . . . . . . . . . . 158

9.13.2 'We will be back here in ten years' time.' . . . . 160

9.13 .3 De politie . . . . . . . . . . . . . . 160

9.13.4 Afsluitende opmerkingen . . . . . . . . . 163

9.13 .5 Conclusie . . . . . . . . . . . . . . . 165

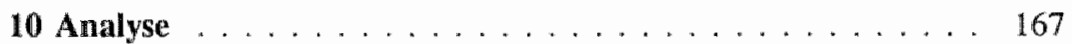

10.1 Inleiding . . . . . . . . . . . . . . . 167

10.2 Reisman . . . . . . . . . . . . . . . 168

10.2.1 'Myth system' en 'operational code' . . . . . . . 168

10.2.2 Kruistochten en hervormingen . . . . . . . . . . 169

10.2 .3 Resultaat . . . . . . . . . . . . . . . 170

10.3 De zes P's . . . . . . . . . . . . . . . . 171

10.3.1 Causes célèbres . . . . . . . . . . . 172

10.3.2 De dood van Blair Peach . . . . . . . . . . 173

10.3.3 Brixton . . . . . . . . . . . . . . . . . 173

10.3.4 De Confait-case . . . . . . . . . . . . . 174

10.3.5 Miscarriages of Justice . . . . . . . . . . 175

10.4 Politie en openheid . . . . . . . . . . . . 176

10.5 Politiek . . . . . . . . . . . . . . . . . 177 
10.6 Herworming van het strafrechtsysteem . . . . . . . . 179

10.7 Afsluiting . . . . . . . . . . . . . . . . 180

11 De reorganisatie van de politie in Nederland . . . . . . . 183

11.1 Inleiding . . . . . . . . . . . . . . . . . . . . . . . . . . . . . . . .

11.2 De Pollitiewet $1993 \ldots \ldots \ldots \ldots \ldots . \ldots \ldots$

11.2.1 De reikwijdte wan de wet ............. 185

11.2.2 Taak , samenstelling en bevoegdheden ....... 186

11.2 .3 Gezag en toezicht over de politie . . . . . . . 186

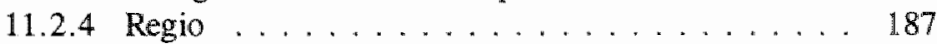

11.2.4.1 Regional college . . . . . . . . . 187

11.2.4.2 Geen eigen politie . . . . . . . . . . . 188

11.2.4.3 Korpsbeheerder . . . . . . . . . . . . . . 189

11.2.4.4 Gemeenteraad ............... 189

11.2 .5 Korpschef ................... 190

11.2.6 Hoofdofficier van Justitie . . . . . . . . . . . 191

11.2 .7 De driehoek ................... 191

11.2.8 Het Korps landelijke politiediensten . . . . . . 192

11.2.9 Beheersbevoegdheden en aanwijzingsbevoegdheden

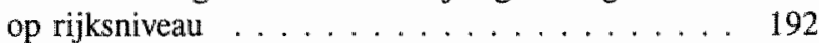

11.2.10 De klachtenregeling . . . . . . . . . . . . 194

11.2.11 Afronding: controle in de Nederlandse Politiewet. 195

11.3 Waarom een nieuwe organisatie? . . . . . . . . . . . 196

11.4 De politieorganisatie in andere Europese landen . . . . . 198

11.5 Een efficiënte organisatie? . . . . . . . . . . . . . . 200

11.5.1 Korpsgrootte-efficiëntie . . . . . . . . . . . . . 200

11.5.2 'Reform without a scandal is no reform' ...... 202

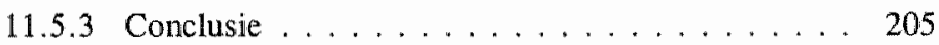

11.5.3.1 Efficiëntie en effectiviteit ....... 205

11.5.3.2 Systeem- of symptoombenadering? . . . 206

12 De controle over de Nederlandse politie . . . . . . . . 207

12.1 Inleiding . . . . . . . . . . . . . . . . . . 207

12.2 Bevoegdheden en de noodzaak tot controle . . . . . . . 208

12.3 Rellen in Amsterdam . . . . . . . . . . . . . . . . . 208

12.3 .1 Juni $1966 \ldots \ldots . \ldots . \ldots 209$

12.3.2 Commissie van onderzoek Amsterdam . . . . . . 209

12.3.3 Het driehoeksoverleg ............. 211

12.3.4 Effectiviteit van het driehoeksoverleg ...... 211

12.4 Het IRT-schandagl . . . . . . . . . . . . . . . . 212

12.4.1 Het Interregionaal Rechercheteam . . . . . . . 212

12.4 .2 Parlementaire enquête . . . . . . . . . . . 214

12.4.3 Ministeriële verantwoordelijkheid ........ 217

12.5 Het tegenwerken wan controle ............. 218

12.6 Ontbreken van controle .............. 220 
13 Slotbeschouwing . . . . . . . . . . . . . . . . 223

13.1 Inleiding . . . . . . . . . . . . . . . . . 223

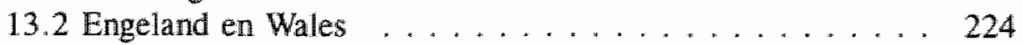

13.2.1 De onafhankelijkheid ............ 224

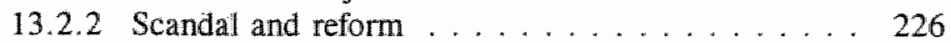

13.2.2.1 Schandalen ............... 226

13.2.2.2 Het traject van de zes P's . . . . . . . . . 226

13.2.2.3 Herwormingen . . . . . . . . . . . . 227

13.2 .3 Controle .................. 228

13.3 Nederland . . . . . . . . . . . . . . . . . . . 229

13.3 .1 Zelfstandigheid . . . . . . . . . . . . . . . . . . . . . . . 229

13.3.2 Scandal and reform . . . . . . . . . . . 230

13.3.2.1 Schandalen ... . . . . . . . . . . . . 230

13.3.2.2 Herwormingen ... . . . . . . . 230

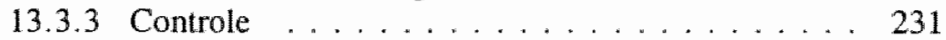

13.4 Conclusie . . . . . . . . . . . . . . . . 232

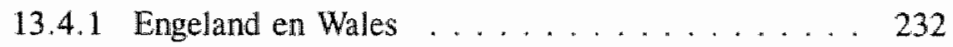

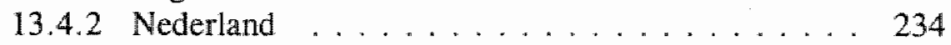

13.5 Ten slotte . . . . . . . . . . . . . . . 237

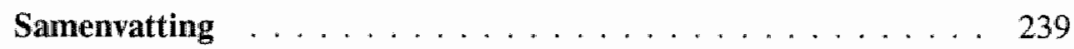

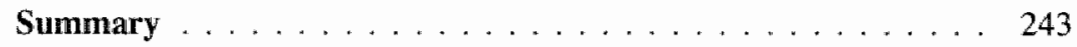

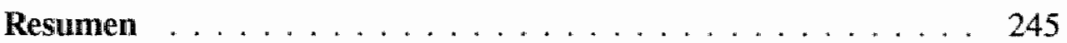

Bijlagen . . . . . . . . . . . . . . . . . . . . . . . . . . . 249

1 Overzicht van de verschillende commissies in Engeland en

Wales. . . . . . . . . . . . . . . . . . . 249

2 Regeringen in Engeland en Wales sinds 1940. . . . . . . 250

3. Interviews . . . . . . . . . . . . . . . . . . 250

Interview met Michael Mansfield QC. in Londen op 13 mei 1993. . . . . . . . . . . . . . . 250

Interview miet Chris Mullin, Member of Parliament . . . . 256

Interview met Alastair Logan, solicitor in de Guildford- en Maguire-zaak en de Judith Ward-zaak . . . . . . 262

Literatuurlijst . . . . . . . . . . . . . . 271

Curriculum Vitae . . . . . . . . . . . . . . . . . . . . 291 


\section{Gebruikte afkortingen}

\begin{tabular}{|c|c|}
\hline $\begin{array}{l}\text { A-G } \\
\text { aant. }\end{array}$ & $\begin{array}{l}\text { Advocaat-Generaal } \\
\text { aantekening }\end{array}$ \\
\hline All ER & All England Law Reports \\
\hline art. & artikel \\
\hline Bijl. Hand. & Bijlagen Handelingen \\
\hline bijv. & bijwoorbeeld \\
\hline C.A. & Court of Appeal \\
\hline CCRA & Criminal Case Review Authority \\
\hline CID & Centrale informatie dienst \\
\hline Cmnd. & Command paper \\
\hline $\mathrm{Comr}_{\text {. }}$ & Commissioner \\
\hline CPS & Crown Prosecution Service \\
\hline Cr. App. R. & Criminal Appeal Reports \\
\hline d.w.z. & dat wil zeggen \\
\hline DPP & Director of Public Prosecutions \\
\hline e.v. & en volgende \\
\hline ed. & editor \\
\hline EHRM & Europese Hof voor de Rechten van de Mens \\
\hline enz. & enzovoorts \\
\hline etc. & etcetera \\
\hline ex p. & ex parte \\
\hline f.e. & for example \\
\hline Guv & Guvnor (baas/meneer) \\
\hline H.C. Deb. & House of Commons Debates \\
\hline H.M.S.O. & Her Majesty's Stationary Office \\
\hline $\mathrm{HR}$ & Hoge Raad \\
\hline i.c. & in casu \\
\hline i..... & id est \\
\hline Ibid. & Ibidem \\
\hline IRA & Irish Republican Army \\
\hline IRT & Interregionaal (Recherche)team \\
\hline J. & Justice \\
\hline jo & juncto \\
\hline jig. & jaargang \\
\hline K.B. & King"s Bench \\
\hline Ltd. & Limited \\
\hline m.a.w. & met andere woorden \\
\hline m.i. & mijns inziens \\
\hline m.nt. & met noot \\
\hline Met. & Metropolitan Police \\
\hline MP & Member of Parliament \\
\hline
\end{tabular}




\begin{tabular}{|c|c|}
\hline $\mathrm{MR}$ & Master of the Rolls \\
\hline mr. & mijnheer \\
\hline mrs. & mewrouw \\
\hline MvT & Memorie van Toelichting \\
\hline $\mathrm{NCB}$ & National Coal Board \\
\hline $\mathbb{N J}$ & Nederlandse Jurisprudentie \\
\hline NJB & Nederlands Juristenblad \\
\hline NJCM & $\begin{array}{l}\text { Nederlands Juristencomité voor de } \\
\text { Mensenrechten }\end{array}$ \\
\hline nir. & nummer/number \\
\hline NUM & National Union of Mineworkers \\
\hline NUPPO & National Union of Police and Prison Officers \\
\hline a.a. & onder andere \\
\hline $\mathrm{o} \cdot \mathrm{m}$. & onder meer \\
\hline OM & Openbaar Ministerie \\
\hline p. & pagina \\
\hline PACE & Police and Criminal Evidence Act \\
\hline para & paragraph \\
\hline $\mathrm{PC}$ & Police constable \\
\hline $\mathrm{PCA}$ & Police Complaints Authority \\
\hline PKP & Project Kwantificering Politiesterkte \\
\hline QB & Queen's Bench \\
\hline QC & Queen's counsel \\
\hline $\mathrm{R} v$. & Rex/Regina versus \\
\hline red. & redactie \\
\hline s.l. & sine loco \\
\hline Stb. & Staatsblad \\
\hline Sv & Wetboek van Strafvordering \\
\hline TK & Tweede Kamer \\
\hline $\mathrm{vgl}$. & vergelijk \\
\hline vol. & volume \\
\hline W. R. & Weekly Law Review \\
\hline
\end{tabular}




\section{Inleiding}

'It is a wery English tmadition that we reform anything only after a panticular scandal."

\subsection{Who polices the police?}

'The fact that the British police are answerable to the law, that we act on behalf of the community and not under the mantle of government, makes us the least powerful, the most accountable and therefore the most acceptable police in the world. ${ }^{2}$ Deze uitspraak die de voormalige hoofdcommissaris van de Londense Metropolitan Police, Sir Robert Mark, in 1977 deed, vormt de aanleiding voor dit onderzoek. De stelligheid van deze uitspraak is voor mij een eerste aanleiding geweest om de inhoud en de vragen die de stelling verder oproept aan een onderzoek te onderwerpen. Is deze uitspraak van Mark mythe of werkelijkheid? Is het mogelijk verantwoordelijk te zijn. zonder op directe wijze verantwoording te dragen of in elk geval af te leggen? Kan volstaan worden met rechterlijke controle of met marginale vragen van de gemeenteraad? Zou de afwezigheid van een directe verantwoordingsplicht niet kunnen leiden tot mogelijk machtsmisbruik? Kan de politie in Engeland en Wales beschouwd worden als een dermate autonoom verantwoordelijke organisatie, dat verantwoording jegens derden overbodig zou zijn? Als dat het geval is dan zou de politie in Engeland en Wales als voorbeeld van integriteit hebben kunnen dienen voor de politie in Nederland, gezien de recente reorganisatie van de Nederlandse politie.

In Nederland kan het parlement vragen stellen over het optreden van de politie aan de minister van Justitie en aan de minister van Binnenlandse Zaken. De minister van Binnenlandse Zaken heeft de uiteindelijke verantwoordelijkheid voor de politie op het terrein van personeel, financiën en de openbare ordehandhaving. De minister van Justitie kan ter verantwoording worden geroepen voor de strafrechtelijke handhaving van de rechtsorde. Het komt geregeld voor dat in de Tweede Kamer door middel van het stellen van vragen actuele politiezaken aan de orde komen.

1. Christopher Price, 13 april 1978, 947, H.C. Deb., 5th Ser, kolom 1808.

'Lurking beneath every discussion about policing and criminal justice is a perwa. sive concept: "police culture"- Academics and journalists reach their conchusions by different routes. But they tend to agree that the culture of British policing is intolerant, reactionary, macho, sexist, and above all. asionishingly resistant to change." Rose, 1996, p. 211.

2. Mark, 1977. p. 56. Deze uitspraak van Mark symboliseen het 'mythe-systeem'. Zie verder. 
In Engeland en Wales is dit niet op deze manier geregeld. De politie staat er in zekere zin verder van de politiek af. De hoofdcommissarissen van de politie in Engeland en Wales, vergelijkbaar met onze korpschefs (vroeger evenals nu in Engeland en Wales hoofdcommissarissen geheten), zijn onafhankelijk. Ze zijn formeel aan niemand verantwoording verschuldigd, ook niet aan een minister of aan een officier van justitie, zoals in Nederland.

Zoals in Nederland is hun hoofdtaak de handhaving van law and order. Hun enige controleur is de onafhankelijke rechter. Zij zijn slechts onderworpen aan de wet. Is dus een wetsvoorstel uiteindelijk wet geworden dan verliezen parlement en regering formeel alle recht op bemoeienis met de politionele handhaving. De parlementsleden kunnen wel vragen stellen aan de regering over de politie, maar de regering kan geen uitleg of antwoord geven, behalwe als het de Metropolitan Police in Londen betreft. Met de politie of het politiebeleid heeft de regering geen directe bemoeienis. ${ }^{3}$ Wel is er vanwege de overheidsfinanciering enige beleidsruimte qua aanstelling en opleiding. Deze situatie bestaat al sinds de introductie van het ambt van politie in Engeland aan het begin van de vorige eeuw.

Door de jaren heen is er organisatorisch wel het nodige gewijzigd binnen het politieapparaat in Engeland en Wales. Om enkele veranderingen te noemen: politiekorpsen zijn samengevoegd, de bevoegdheden van de politie zijn uitgebreid en enkele gespecialiseerde agenten zijn bewapend. De onafhankelijkheid van de politie is echter nooit onderwerp geweest van een voorstel of wijziging van wet. In deze studie gaat het om deze onafhankelijkheid en on de gevolgen van die onafhankelijkheid. Ik ben met name geïnteresseerd in de problemen die kunnen voortvloeien uit die onafhankelijkheid ${ }^{4}$. Deze problemen wil ik op het spoor komen via concrete praktijkgevallen, waarbij het gedrag van agenten ter discussie staat.

Men zou zich kunnen afvragen wat het individuele gedrag van agenten te maken heeft met het ontbreken van onafhankelijkheid van het politieapparaat in het algemeen. Het gedrag van individuele agenten kan binnen een korps uitgroeien tot een algemeen probleem, wanneer bepaald gedrag door meer agenten vertoond wordt. Door de buitenwereld kan het gedrag vervolgens opgevat worden als een algemeen organisationeel probleem van de politie,

3. Zie verder.

4. In dit proefschrift heb ik Schotland en Noord-lerland buiten mijn onderzoek gehouden. De wettelijke regelingen in deze landen verschillen zodanig met de situatie in Engeland en Wales, dat een onderzoek dat alle landen binmen het Verenigd Koninkrijk van Groot-Brittannië en Noord-lerland omvat, te uitgebreid en onoverzichtelijk zou zijn geworden. Daarnaast zou een uitbreiding tot die landen niet tot een verheldering hebben geleid van de probleemstelling. 
waardoor het gedrag uitgegroeid is tot een actueel maatschappelijk probleem.

\subsection{Probleemstelling: De onafhankelijkheid van de politie}

De onafhankelijkheid wan de politie in Engeland en Wales is wanuit Europees oogpunt uniek. Vanaf de introductie van het politiekorps in Londen in 1829 staat die onafhankelijkheid vast. In de literatuur wordt als reden voor die onafhankelijkheid genoemd dat men in Londen bevreesd was voor een politie naar Frans model. ${ }^{5}$ In die tijd had de Franse politie geen goede naam. Deze politie zou bestaan uit verklikkers en spionnen en stond onder manipulatieve leiding van de Franse heersers. Men was aan de andere kant van het Kanaal bevreesd dat de invoering van een politie naar Frans model het einde van de vrijheid van de burgers zou teweegbrengen en dat de politie als een machtsmiddel gebruikt zou worden om een politieke coup te plegen. ${ }^{6}$ Die vrees is sindsdien gebleven en ook in de huidige politiek valt op hoezeer men nog steeds de madruk legt op het hebben van een onafhankelijke politieorganisatie. Het ligt dan ook niet in de werwachting dat hieraan. op korte termijn ingrijpend getornd zal worden.

In deze studie staat de vraag naar de onafhankelijkheid van de politie centraal. Waar komt deze onafhankelijkheid vandaan? Wat vinden de politieke partijen ervan dat zij geen mogelijkheid hebben de politie ter verantwoording te roepen? Wat zijn de gevolgen van deze onafhankelijkheid voor het vertrouwen van de burgers in de politie? Wanneer de politie staat op onafhankelijkheid en als zij het vertrouwen wan de burgers wil hebben, wat stelt zij daartegenover om deze policing by consent te verwerven? Biedt zij de burgers een visible, effective en legitimate opsporings- en vervolgingsbeleid, waardoor het vertrouwen in de politie gerechtvaardigd wordt? Kunnen de burgers wanneer zij problemen hebben met bepalald politieoptreden terecht bij een klachtenprocedure en, zo ja, hoe functioneert die dan? Kan van overheidswege toch informeel of indirect invloed uitgeoefend worden op de beleidsvorming door de politie? En wat betekent de onafhankelijkheid voor de werhouding tussen politie als opsporingsapparaat en de Crown Prosecution Service (vergelijkbaar met het Nederlandse Openbaar Ministerie) als vervolgende instantie?

Al deze vragen zijn eigenlijk alleen maar relevant als er reden is te vermoeden dat de onathankelijkheid zo nu en dan voor problemen zorgt. In deze studie wil ik gevallen laten zien waarin het ontbreken van de plicht verantwoording af te leggen tot problemen heeft geleid. Problemen ontstaan over

5. Zie Emsley, 1987, Critchley, 1979 en Fijnaut, 1979.

6. Emsley, 1987, p. 172; Critchley, 1979, p. 35. 
het algemeen indien de burgers niet tevreden zijn over het contact met de politie. Bij dat contact wil ik nu even stilstaan.

\subsection{De politie en de maatschappij}

Wetshandhaving en ordehandhaving zijn maar een beperkt deel van de politietaak. Informatieverlening, hulpverlening en administratie zijn ook belangrijke taken. Deze dualiteit in taken - de dienstverlenende versus de justitiële - geeft een zekere spanning. Enerzijds wordt de politie waak gevraagd om bij een probleem aanwezig te zijn, anderzijds proberen burgers de politie bij hun (illegale) werkzaamheden te mijden. ${ }^{7}$ De dienstverlenende taak komt niet aan de orde in deze studie, omdat deze taak over het algemeen weinig ${ }^{8}$ publieke controverse in het bele id oproept. De politie bewijst de burgers met deze werkzaamheden een dienst. ${ }^{9}$ Deze werkzaamheden hebben het voordeel dat ze goed zijn voor het imago van de politie. ${ }^{10}$

Het contact tussen burgers en politie bij de justitiele taak is echter wel vaak oorzaak van spanningen. Zulk contact kan wel tot een klacht leiden. Het is derhalve voor een goed imago wan de politie van belang dat de politie bij het contact met de burgers zich aan de regels houdt. De hoofdcommissaris is medeverantwoordelijk voor het gedrag van de agenten op straat. De geloofwardigheid en het wertrouwen van de burgers in de politie hangen af van een correct politieoptreden. De hoofdcommissaris moet erop toezien dat de agenten in zijn korps zich aan de wet houden. Dit is een moeilijke taak, omdat elke agent een eigen discretionaire bevoegdheid ${ }^{11}$ heeft. Hoe lager in rang, hoe meer vrijheid van handelen. ${ }^{12}$ Aangezien agenten op straat werken, is er weinig toezicht. Agenten werken alleen of met zijn tweeën. Bij hun werk zullen agenten noodzakelijkerwijs keuzen moeten maken. Op een of andere wijze moet de hoofdcommissaris erachter zien te komen welk. gedrag agenten tijdens patrouilles vertonen en of dat gedrag eventueel gewijzigd moet worden. ${ }^{13}$ Drie auteurs, Wilson, Gardiner en Sherman, hebben theorieen ontwikkeld over het (strafbaar) gedrag van agenten. Deze auteurs wordlen hieronder behandeld.

7. Zie over de contacten tussen politie en burgers het boek wan Black. $1980 \mathrm{en}$ Wilson, 1985, p. 90-114; Punch, 1979 (B), p. 102-117; Van der Vijver, 1993.

8. Behalve binnen het politieapparaat zelf. 'Zijn we agenten of zijn we maatschappelijk werkers?"

9. Wilson, 1968, p. 3-4; zie ook Schuyt, 1983, p. 167; Reiner, 1995, p. 9.

10. Wilson, 1968 , p. 5.

11. Zie 4.7.

12. Zie ook de constabulary independence-theorie en Sanders, 1994, p. 776-777.

13. Wilson, 1968, p. 8, 278. 


\subsection{De theorie van Wilson}

Wilson heeft in zijn boek Varieties of Police Behaviour uit 1968 het politiegedrag onderzocht. ${ }^{14}$ De manier waarop agenten omgaan met de wet was met name onderwerp van onderzoek. Daarbij speelde de discretionaire bevoegdheid van een agent een grote rol: wanneer, hoe en boe vaak wordt deze bevoegdheid gebruikt. De bevoegdheid kan een probleem zijn als grenzen overschreden worden. Wilson stelt dat in die tijd in Amerika agenten geacht werden formeel geen gebruik te maken van de discretionaire bevoegdheid. ${ }^{15}$ Het dulden van het gebruik van de bevoegdheid door agenten en vervolgende instanties brengt impliciet met zich mee dat zij uitmaken hoe de wet toegepast moet worden. ${ }^{16} \mathrm{Zij}$ hebben de mogelijkheid wetsovertredend gedrag in sommige gevallen door de vingers te zien, terwijl andere strafbare feiten op andere momenten wel bestraft worden. De alledaagse praktijk brengt mee dat dit ook niet anders kan. ${ }^{17}$ Het is eenvoudig niet mogelijk alle strafbare feiten te verbaliseren. Het kan echter problemen geven wanneer de politie identieke problemen anders oplost. ${ }^{18}$ Dan zouden de benadeelde burgers naar de rechter kunnen stappen. Desalniettemin wordt het gebruik van de discretionaire bevoegdheid tot op zekere hoogte geduld. ${ }^{19}$ Wilson heeft in zijn studie gekeken hoe de top van de organisatie

14. In 1964 en 1965 braken er grote rassenrellen uit in New York en Los Angeles. De oorzaak werd gezocht bij de politie. Vandaar dat er in de jaren daarna vele politiestudies verricht werden. De studie van Wilson, van de Harvard University, is er één van. Sherman, 1974, p. 256-257. Zie woor een overzicht van Amerikaans onderzoek naar politiegedrag Sherman, 1980, p. 69-99.

15. Wilson, 1968, p. 7; In sommige staten geldt het nog steeds. "In the USA many states adopted full enforcement statutes, requiring the police to initiate criminal proceedings whenever they had evidence of an offence (...). From this perspective, the commonly observed tendency of the police to under-enforce the law by dealing with many incidents in a peace-keeping rather than law-enforcement style (...) is inlegal and scandalous.' Reiner, 1994, p. 723.

16. Vgl. Packer, 1968, p. 290. Zie hierover ook Reisman, 1979, p. 6-7. Reisman zegt dat de vervolgende instanties vaak gedwongen zijn om de discretionaire bevoegdheid uit te oefenen, maar, zegt hij werder: "The fact that discretion is applied to withhold prosecution in many cases that violate the formal law does not necessarily mean that an operational code has now been prescribed that they are legitimate.' 1979 , p. 6-7.

17. Zie ook Reiner, 1994, p. 723.

18. Zoals Reiner ook opmerkt in zijn artikel Policing and the Police, 1994, p. 723. 752.

19. In de zaak $R$ V. Metropolitan Police Comr., ex p. Blackburn (1968) 2 QB 118 , (1968) I All ER 763 zag de rechter zich gesteld voor de vraag in hoeverre de politie verplicht was de wet strict te handhaven en overtredingen te vervolgen. 
de lagere rangen ertoe kan bewegen beheerst en controleerbaar van de bewoegdheden gebruik te maken. ${ }^{20}$

Een hoofdcommissaris kan het gedrag van agenten volgens Wilson op twee manieren sturen: bureaucratisering en professionalisering. ${ }^{21}$ Bureaucratisering houdt in dat meer gedrag aan regels wordt gebonden en dat daardoor meer gecontroleerd kan worden. Het gevolg hiervan is dat er meer toezicht en minder vrijheid van handelen voor de agent ontstaat. Dit betekent een terugdringen van de discretionaire bevoegdheid. Volgens Wilson geven juristen over het algemeen de voorkeur aan deze oplossing. Daartegenover staat professionalisering. In zijn definitie van professionalisering betekent dat juist meer initiatief, meer onathankelijkheid en meer contact met de burgers. De relatie met de burgers wordt belangrijk geacht. Het beeld dat wij tegenwoordig hebben van de ouderwetse veldwachter voldoet hieraan. ${ }^{22}$ Bij deze invalshoek is er meer contact mogelijk tussen agenten en de lokale bevolking. ${ }^{23}$ Bureaucratisering kan als nadeel hebben dat de indruk wordt gewekt dat de baas geen vertrouwen in zijn agenten heeft. Professionalise-ring kan daarentegen een gevoel van irrelevantie oproepen, m.a.w. dat de baas niet geinteresseerd is in het werk van zijn agenten. ${ }^{24}$ Een combinatie van professionalisering en bureaucratisering lijkt het beste. Maar hoe zou dit moeten worden verwezenlijkt? Om die vraag te beantwoorden noemt Wilson in zijn boek twee modellen voor de handhaving van wet en orde:

- het institutional model. Dit model wordt vaak woorgestaan door de agenten zelf. Het houdt in dat de wet nageleefd moet worden omdat anders de wet zelf ter discussie staat. Hier tegenover staat:

- het communal model. Elke buurt heeft andere waarden en normen. In de ene wijk worden door de bevolking meer en andere dingen geaccepteerd dan in een andere wijk. ${ }^{25}$ Wetshandhaving geschiedt het

19: $\rightarrow$

In deze zaak luidde het antwoord dat wetshandhaving een zaak voor de hoofdcormmissaris was, en niet voor de techter.

20. Willson, 1968, p. 11 .

21. Wilson, 1968, p. 281.

22. Wilson, 1968, p. 282.

23. Willson, 1968, p. 281-282, 285.

24. Wilson, 1968, p. 283-284.

25. Dit is een op dit moment actueel concept vamwege het feit dat de Nederlandse samenleving zeer duidelijke multiculturele kenmerken bezit. De vraag komt dan boven hoe met deze samenleving on te gaan. Is eén politiek strafrechtelijk beleid of wetshandhaving voor het hele land wel aan te bevelen, met andere woorden moet gekozen worden voor uniformiteit of voor verscheidlenheid? Beide "oplossingen' kunnen tot onrechtvaardigheid leiden. Mensen die de verscheiden- 
meest efficiënt als het de steun heeft van de mensen uit de buurt. De wijkagenten wonen in de buurt waar ze werken. En voor de buurt zelf zijn de agenten en hun gedrag individualiseerbaar. ${ }^{26}$

Het maakt voor elk van deze twee modellen niet uit hoe de gezagsstructuur van de organisatie in elkaar zit. Het lijkt erop dat het institutional model bij de bureaucratisering past en het communal model bij de professionalisering. Maar Wilson heeft in zijn onderzoek aangetoond dat dat niet noodzakelijk is. Ook in een politiekorps waar het gezag centraal geregeld is, dus bureaucratisch ingedeeld is, kan het institutional model ontbreken. ${ }^{27}$

Wilson is zeer voorzichtig in het formuleren van conclusies over de gezagsverdeling in zijn studie. ${ }^{28} \mathrm{Hij}$ is er voorstander van om de politie naar de buurten te brengen, d.w.z. de dienst te decentraliseren. Daarwoor is het echter niet nodig dat het gezag ${ }^{29}$ ook gedecentraliseerd wordt. Dit is bovendien niet wenselijk, want een grote stad heeft ook problemen die boven het niveau van de wijken uitkomen. Wilson heeft geen bezwaar tegen het decentraliseren van de functies van de politie, maar wel tegen het verspreiden van macht. ${ }^{30}$ Immers, als macht op een lager niveau wordt gebracht, daalt het gezag dat van de lokale onderdelen uitstraalt. Men heeft dan minder achting voor de organisatie.

Wilson stelt het volgende voor. Aan de ene kant moeten agenten beter bekend wonden met hun surveillancewijk. Het sociale contact met burgers en de zichtbaarheid op straat zijn daarbij de eerste vereisten. Aan de andere kant zouden de hoofden wan de politie andere eisen moeten stellen aan hun agenten. Niet zozeer objectieve maatstaven als arrestatiecijfers moeten beloond worden, maar het vermogen van de agent om rust, orde en tevredenheid onder de burgers in zijn wijk te bewaren. Dat vraagt behoorlijk wat professionalisering en eigen initiatief van een agent. Tegenover deze profes-

25. $\rightarrow$

heid van de samenleving onderkemen, zijn het niet eens met een uniforme behandeling. Degenen die uniformiteit woorstaan wensen niet werschillend behandeld te worden.

26. Wilson, 1968, p. $285-288$. Veel van wat Wilson al in 1968 aanwoerde, is relevant voor de hedendaagse discussies over de functie en plats van agenten in steden en op het platteland. Een vergelijking wan het communal model met de regiopolitie ligt woor de hand. Op een of andere manier komt men telkens terug bij oude bestaande denkbeelden.

27. Wilson, 1968, p. 287-288.

28. Wilson, 1968, p. 290.

29. Als machtsbevoegdheid: bevoegdheid om zonodig door macht te handhaven beslissingen te nemen.

30. Wilson, 1968, p. 287, 288, 290. 
sionalisering staat een centraal gezag dat verantwoordelijk is voor de handhaving wan de wet. ${ }^{31}$

\subsection{De theorie van Gardiner}

In 1970 schreef Gardiner een boek over The politics of corruption bimnen wetshandhavende instanties, i.c. de politie: Het doel van deze studie was om meer inzicht te krijgen in de corruptie. Daarbij onderzocht Gardiner of er verbanden waren tussen corruptie, wetshandhaving en lokale politiek. Gardiner besloot zijn studie met een overzicht van een aantal manieren om ongewenst gedrag ${ }^{32}$ van agenten te verminderen of te voorkomen.

'Corruption is a persistent and practically ubiquitous aspect of political society: it is unlikely that any reforms will ever eliminate it completely.' ... "And, ..., in any large organization, whether it be a police department, taxcollection agency, labor umion, or multimillion-dollar corporation, there will always be individuals who will find the rewards of corruption greater than the satisfactions of legitimate behovior. ${ }^{33}$

Als corruptie dan nooit volledig uit te bannen is, hoe kan het dan binnen een organisatie verminderd worden? Gardiner zocht de oplossing daarvoor in het verbeteren van de interne structuur van de organisatie. Daarbij doelde hij met name op de positie van de agent. Agenten zouden meer zekerheid moeten krijgen over hun loopbaan en hun toekomst bij de politie, een soort carrièreplanning. $\mathrm{Zij}$ zouden beter betaald moeten worden en promoties zouden bij correct gedrag voor de hand moeten liggen. Gardiner stelde woor de politiek zoveel mogelijk buiten de deuren van de organisatie te houden. Het vooral in de Verenigde Staten van Amerika gehanteerd gebruik dat burgemeesters en andere functies in de lokalle politiek direct gekozen worden door de burgers kan corruptie in de hand werken. ${ }^{34}$ Deze politieke structuur kan indürect een oorzaak zijn woor problematisch gedrag bij agen-

31. Wilson, 1968, p. 292 . Wilson schreef over de Verenigde Staten en niet over Engeland en Walles. Vandaar dat hij het heeft ower een centraal gezag dat 'verantwoordelijk $k^{*}$ is voor de handlhaving van de wet.

32. Gardiner heeft het specifiek over corruptie dat hij als wolgt omschrijft: 'corruption is political behavior which deviates from the formal duties of a public role because of private-regarding (personal, close family, private clique) pecuniary or status gain; or violates rules against certain types of private-regarding influence." Deze definitie heeft hij overgenomen van J.S. Nye, 'Corruption and Political Development: a Cost-Benefit Analysis", American Political Science Review, LXI (June), 1967, 419.

33. Gardiner, 1970, p. 93-94.

34. Gardiner, 1970 , p. 100. 
ten, omdat het agenten afhankelijk maakt van de steun wan de politiek waardoor het beïnvloeden van agenten mogelijk wordt. Het moet dus niet zo zijn dat de financiële toelage voor het politieapparaat of de kans op promotie afhankelijk wordt van het al dan niet volgen van een bepaald politiek beleid. Hoe minder de politiek de kans heeft invloed uit te oefenen op (individuele) politieagenten en hoe zekerder de positie van de agent in het politieapparaat is, hoe minder kans bestaat dat agenten in illegale circuits terechtkomen. Gardiner stelde wel in zijn betoog dat controle van het politieapparaat door local officials belangrijk is. ${ }^{35}$ In dit geval is het juist goed als de politiek het politiewerk evalueert. Daarmee bedoelt hij de aanwezigheid van belangengroepen, burger-organisaties en alle politieke partijen. Dan heeft de controle een brede basis en kan, wanneer er iets fout gaat, ingegrepen worden.

Gardiner's boek behandelt het vóórkomen van corruptie. Zowel in de casestudy, door Gardiner beschreven " als in de in deze studie beschreven gevallen gaat het over het ontbreken van controle en over het overnemen van de formele controle door andere vormen van controle. In het betoog van Gardiner is de casus een zwakke hoofdcommissaris, onderworpen aan de grillen van plaatselijke burgemeesters en zakenmensen. In de zaken die ik in deze studie bespreek, zullen we zien dat het gevallen van verkeerd politiegedrag betreft waarbij de interne controle gering en de externe controle geheel afwezig is. Al is de aard van het "misdrijf' verschillend - 'klassieke' corruptie versus de zogenaamde "noble cause corruption" (zie verder) - de achtergrond van falende controle is nagenoeg gelijk.

\subsection{De theorie van Sherman}

\subsubsection{Schandalen en hervormingen}

Sherman heeft in 1978 een onderzoek gepubliceerd over politieschandalen in enkele Amerikaanse steden. Daarbij ontdekte hij dat met name rond de verkiezingstijd vaker schandalen door politici aan de oppervlakte werden gebracht waardoor veel ophef ontstond. Deze schandalen zorgden ervoor dat politici in hun verkiezingscampagne zich konden profileren en steun kregen van grote lagen van de bevolking door te beloven de strijd aan te zullen binden tegen deze schandalen. Sherman integreert hiermee de kern van het betoog van Gardiner en Wilson over de oorzaken en het voorkómen van comupt gedrag onder agenten. De theorie die Sherman naar aanleiding van deze casuïstiek uitwerkt, sluit direct aan bij mijn vraagstelling naar de "quest for control' van politieorganisaties. Zijn theorie richt zich op het verband ussen schandalen en hervormingen. Aangezien Sherman hiermee een wijze 
aangeeft waarop naar ontwikkelingen van de politie op het terrein wan de onafhankelijkheid en de controle gekeken kan worden, is dit reden om wat uitvoeriger stil te staan bij zijn studie.

De titel van het boek van Sherman is een samenvatting van de inhoud: schandaal en hervorming ${ }^{36}$. Sherman beweert dat in veel gevallen van politiecorruptie een schandaal ${ }^{37}$ nodig was om een verandering in of een hervorming van de politieorganisatie te bewerkstelligen ${ }^{38}$ Van huis uit lijkt de politieorganisatie afkerig van veranderingen. Om de juistheid te onderzoeken van deze theorie is Sherman gaan kijken bij vier verschillende politiekorpsen wanaf het moment dat daar een corruptieschandaal aan het licht kwam. ${ }^{39}$ Alvorens zijn theorie verder te bespreken zal ik eerst de term schandaal nader uitwerken.

\subsubsection{Definitie schandaal}

Een schandaal kan omschreven worden als een massale reactie van afkeuring en soms woede op het ontdekken van een discrepantie fussen theorie en praktijk. Een wezenlijk element is dat het bij een schandaal moet gaan om het (onverwachts) schenden van vertrouwen dat men in iets, iemand of een organisatie heeft, ${ }^{40}$ Een schandaal kan ontstaan als er een conflict is tussen de verwachtingen van het publiek en de organisatie zelf over de doelstelling van de organisatie ${ }^{41}$ en de verwezenlijking daarvan. Van essentieel belang is volgens Sherman dat dit conflict door een moral crusadert of entrepreneur naar woren wordt geschoven, op zo'n manier dat het opgepakt wordt door de media.

36. Sherman, 1978 .

37. Hierbij moet de rol wan de media en, vooral in de Verenigde Staten van Ameri$\mathrm{ka}$, de rol van de verkiezingen niet onderschat worden.

38. Deze theorie van Sherman vinden we ook terug bij Wilson, 1968, en bij Gardiner, 1970.

39. Sherman heeft later een dergelijk verband tussen schandaal en hervorming trachten aan te tonen bij het gebruik van politiewapens. Sherman, in Punch, 1983 (B).

40. Sherman, $1978, p, x i i, 60-64$; 'Scandal is a social reaction to a violation of socially invested trust in an institution or role, " p. 61.

41. Organizational character: "The formation of an institution is marked by the making of value commitments, that is choices which fix the assumptions of policymakers as to the nature of the enterprise - its distinctive aims, methods, and role in the community.' Selznick, 1957, p. $53-55$; '... a substantial conflict over the goals of the legal system.' Gardiner, 1970, p. 94.

42. De term is overgenomen van Becker, 1963, p. 147-162. 


\subsubsection{Het onthullen van een schandaal}

Pers en media spelen in het algemeen een grote rol in het naar buiten brengen van feiten, welke geïnterpreteerd kunnen worden als afkeurenswaardige daden van de politie. ${ }^{43}$ De politieorganisatie maakt de fouten die individuele agenten begaan meestal niet openbaar. Mistoestanden komen daarom alleen aan het licht doordat iemand van binnen de organisatie ze naar buiten brengt of doordat een burger klaagt. Het ligt voor de hand dat instrumenten als de krant en andere media ingeschakeld worden om bekendheid te geven aan misstanden binnen het politie-apparaat. Echter, net als de politie zijn ook de media selectief. $\mathrm{Zij}$ maken de keuze om wel of geen ruchtbaarheid aan mistoestanden te geven. Daarmee wil ik aangeven dat de dynamiek van het onthullen van mistoestanden bij uitstek een sociaal product is: het is niet vanzelfsprekend dat bij het bekend worden van een gebeurtenis bij de media deze zaak van dezelfde media ook alle andacht krijgt. ${ }^{44}$

Een mistoestand bij de politie ontwikkelt zich eerder tot een schandaal dan een mistoestand bij een bedrijf. Het instituut politie, die de law and order moet handhaven, wordt juist geacht zich conform de wet en de regels te gedragen. Hier zijn de verwachtingen hoger. De politie zou het goede woorbeeld moeten geven. Immers, een politie die zelf de wet overtreedt, moet niet vreemd opkijken wanneer burgers hetzelfde gedrag vertonen. Bovendien wordt van het politieapparaat verwacht dat zij het criminele gedrag van de individuele agenten aanpakt. Faalt men daarin binnen de eigen organisatie, dan wordt het vertrouwen van de burgers geschonden. ${ }^{45}$ Dit vertrouwen is

43. Vgl. de onthulling van een corruptieschandaal bij de Nederlandse politie in de jaren zeventig. De pers bracht het schandaal in dit geval niet aan het licht, maar schreven er een aantal jaren uitgebreid over in kranten en tijdschriften: Punch. 1983 (A), p. 11.118, 119; Punch, 1983 (C), p. 227-250; Een ander voorbeeld is Hall, Critcher, Jefferson, Clarke, and Roberts, 1978.

44. Toch moet de rol van de media ook weer niet overtrokken worden. Reisman, 1979, p. 103 zegt het volgende over de rol van de media in antibribery campaigns: "The media in contemporary mass societies play prominent roles in purity crusades. ... Plainly the media are substantial influences in opinion formation and are even more important in sustaining and maintaining opinions already formed ... by providing supporting information and authority. But how fundamental that role or whether the media are the key cause is difficult to say. Without empirical studies, I am inclined to doubt that there are substantial causal dimensions to an obvious correlation. The fact is that there are always reform sheets or tracts on sale; even in organs of more general circulation, there are regular and syndicated crusading, bellyaching, and muckraking columns and features. You can't crusade without the medlia, but a crusade is much more than a media event.'

45. Vgl. Punch, 1983 (A), p. 105. 
derhalve precair en bepaalt het imago dat de burgers hebben van de politie. Een verminderd vertrouwen geeft een slechter imago.

\subsubsection{Reageren op een schandaal}

Het hoeft niet altijd vanzelfsprekend te zijn dat na openbaarmaking van een incident soortgelijke voorvallen woortaan niet meer zullen voorkomen. Daar geeft Sherman twee redenen voor. Ten eerste leidt wangedrag niet altijd tot een verandering van de wet, van de houding of van het gedrag van agenten of tot een verandering in het beleid. Indien alleen enkele individuen ontslagen of overgeplaatst worden, hoeft de oorzaak van het probleem nog niet weggenomen te zijn. ${ }^{46}$ Daarnaast hangt het mede af van de grootschaligheid van het probleem en de hoeveelheid aandacht die de pers aan het voorwal besteedt, of en in hoeverre het voorval verandert in een schandaal." ? Van belang is tevens de omvang van de sociale verontwaardiging en de maatschappelijke onrust. ${ }^{48}$

\subsubsection{Reacties van agenten}

De studie van Punch over corruptie bij de Amsterdamse politie laat zien dat binmen een organisatie als de politie enkele typische reacties opgemerkt kunnen worden. ${ }^{49}$ De negatieve publiciteit die voortvloeit uit een schandaal, zorgt er in eerste instantie voor dat de politieorganisatie als een eenheid naar buiten treedt: Het gevoel van solidariteit is sterk, wooral in de lagere gelederen. ${ }^{50}$ Volgens Skolnick in zijn boek Justice without trial is deze politiesolidariteit inherent aan de functie van politieagent.

"All occupational groups share a measure of inclusiveness and identification. People are brought together simply by doing the same work and having similar career and salary problems. As several writers ruve norea, nowever, police show an unusually high degree of occupational solidarity. ... Set apart from the conventional world, the

46. Sherman, 1978, p. xviii.

47. Bijw hoe groot is de sociale verontwaardiging. Besteedt de pers zoveel aandacht aan het probleem dat er maatschappelijke onrust ontstaat? Sherman, 1978, p. 79.

48. Bijv. de mishandeling van Rodney King in Los Angeles "die toevallig op videoband was opgenomen. Zou deze videoband waarop mishandelende agenten staan mede verantwoordelijk zijn voor de vrijspraak in de O.J. Simpson-zaak, waarin de integriteit van de agenten ook aan de orde was?

49. Punch, 1979 (A); en Punch, 1983 (C), p. 234-247.

50. Punch, 1983 (C), p. 234-235. 
policeman experiences an exceptionally strong tendency to find his social identity within his occupational milieu. ${ }^{51}$

Dit solidariteitsgevoel geldt in zekere zin voor alle beroepen en functies. Desondanks vallen agenten op vanwege hun zelfde kijk op de wereld en vanwege het feit dat zij zich zo sterk socialiseren binnen hun werkkring. ${ }^{52}$ De oorzaak van dit gevoel is volgens Skolnick te vinden in de politiecultuur die veel te maken heeft met gevaar, macht en lack of public response. ${ }^{53}$ Het solidariteitsgevoel heeft als consequentie dat agenten elkaar meer zullen dekken en niet snel tegen elkaar zullen getuigen, hetgeen het moeilijk maakt een onderzoek naar de juistheid van de feiten uit te voeren. ${ }^{54}$ Vanwege dit gevoel van solidariteit komt crimineel gedrag van agenten maar zelden in de openbaarheid. Grenzen moeten echt overschreden worden, wil men als medewerker de vuile was buiten hangen. ${ }^{55}$ Bovendien, agenten die wel in het openbaar tegen hun collega's getuigen en dus de stilte doorbreken, krijgen het in de organisatie zwaar en worden onderworpen aan tegenwerkingen van hun collega's. ${ }^{56}$ Politieagenten die beschuldigd worden van bepaalde vormen van crimineel gedrag ${ }^{57}$, ontvangen van hun collega's veel sympathie en steun. Zij worden beschouwd als zondebokken die moeten boeten voor gedrag dat veel breder in de organisatie voorkomt. Deze agenten zouden doorgaans niet in hun eigen belang handelem, maar zoals beweerd in het belang van de politieorganisatie. $\mathrm{Zij}$ trachten met dit illegaal gedrag lopende strafzaken rond te krijgen, waardoor binnen de organisatie het gedrag gelegitimeerd wordt. ${ }^{58}$

\subsubsection{Reacties van de top van de politie op korte termijn}

Een schandaal kan gevolgen hebben voor de politie als maatschappelijke organisatie. Een schandaal heeft een behoorlijk negatief effect op het imago

51. Skolnick, 1975, p. 52.

52. Skolnick, 1975, p. 52-53.

53. Skolnick, 1975, p. 53-58.

54. Skolnick noemt in zijn boek een waar gebeurd incident uit 1963 van enkele agenten uit Sheffield die vier verdachten mishandelden, teneinde bekentenissen te krijgen. Hoewel meerdere agenten van het incident op de hoogte waren, werd het feit niet gerapporteerd door agenten. 1975, p. 68-69.

55. Zoals bijv geldt voor agent Frank Serpico uit één van de casussen van het boek van Sherman, die eerst getracht had de corruptie via interne wegen aan te pakken hetgeen niet gelukt was. Sherman, 1978, p. 73; Zie ook Maas, 1973. Vgl. eveneens Van Daalen, 1991.

56. Punch, 1983 (C), p. 235-236; zie ook het interview met Chris Mullin.

57. Soms wordt crimineel gedrag door mede-agenten niet getolereerd, met name niet wanneer collega's door dit gedrag in gevaar gebracht worden.

58. Punch, 1983 (C), p. 238. 
yan een organisatie. In de gevallen die Sherman in zijn boek beschrijft, zien we dat de onthulling van politiecornuptie bimen een enkele dienst reeds tot gevolg heeft, dat de politieorganisatie in haar geheel als een corrupte organisatie gezien wordt. ${ }^{59}$ In normale omstandigheden zal de organisatie dit willen voorkomen, en trachten de overgang van een misstand naar een schandaal te verhinderen met behulp wan interne controle-mechanismen. Dit laatste is echter niet altijd mogelijk, vooral als een interne controlestructuur niet aanwezig is of faalt in haar taak. ${ }^{60}$ In die gevallen moet de organisatie naar andere middelen grijpen. Daarbij kan gedacht worden aan - cfr. de rotte appel theorie - het verlenen van ontslag, aan het benoemen van een nieuwe directeur en aan het ontwikkelen van nieuw beleid voor de toekomst, vooral op het gebied van de interne controle. "Scandal realigns the structure of power over a police deparment... ${ }^{62}$, maar - zoals Sherman terecht opmerkt - deze nieuwe structuur hoeft niet direct een verbetering te betekenen.

Reisman heeft in zijn boek Folded Lies een onderscheid gemaakt tussen twee mogelijke reacties van de overheid op publieke ontevredenheid over het overheidsoptreden of -beleid. Ten eerste zijn er de echte hervormingen, die ten doel hebben het gedrag drastisch te veranderen. ${ }^{63}$ Deze hervormingen kunnen gelijk gesteld worden aan de hervormingen die volgens Sherman volgen op een groot schandaal. Daarnaast echter signaleert Reisman een andere mogelijke reactie van de overheid. Deze reactie, die hij een kruistocht (crusade) noemt, is niet automatisch gericht op het veranderen van beleid of optreden, maar eerder op het terugwinnen van het vertrouwen van de bevolking in het systeem. In dat geval wordt er net gedaan alsof er hervormd wordt. Men kan dan denken aan het invoeren van bepaalde nieuwe matregelen die in feite de praktijk niet of nauwelijks wijzigen, maar het publiek wel het idee geven dat er aan het probleem iets gedaan wordt. 'Crusades, as we have seen, are aimed not at changing behavior but at reasserting the values of the myth system and reassuring those committed to it of the continuing validity of the myth without changing the behavior that was the manifest stimulus of the crusade. ${ }^{64}$

59. Sherman, 1978, p. 206.

60. Sherman, 1978, p. $72-78$.

61. Sherman, 1978, p. 92 .

62. Sherman, 1978, p. xviii.

63. Reisman, 1979, p. 111.

64. Reisman, 1979 , p. 110. 


\subsubsection{Reacties in het beleid op lange termijn}

'... it is not always easy to determine whether a particular campaign is a reform or a crusade. The final judgment can be made only yoars later, when it is possible to assess whether legislation has led to aggregate changes in targeted behavior. ... What had perhaps started as a reform has been transpormed into a crusade. ${ }^{\text {nis }}$

Niet alle schandalen hebben een gunstig effect op het gedrag wan (de leden van) een organisatie. Dat hangt mede af van de omvang van het schandaal. Sherman heeft in zijn boek geconcludeerd dat kleine schandalen zelden invloed hebben op een organisatie. De organisatie zal in het geval van een gering vergrijp niet gauw overgaan tot een wijziging van het beleid. Immers, het imago van de organisatie is niet of nauwelijks aangetast. Schandalen die uitgebreid in de publiciteit (geweest) zijn en van grotere omvang zijn, hebben daarentegen wel effect op de organisatie, ook al is het effect van korte duur. ${ }^{66}$ Het is belangrijk dat de organisatie bij een wijziging het beleid toespitst op premonitory control, en het niet laat bij postmonitory control. ${ }^{67}$ Premonitory control houdt in dat organisaties gescreend worden op crimineel gedrag zelfs voordat er aanwijzingen zijn dat crimineel gedrag in de organisatie voorkomt. ${ }^{68} \mathrm{Er}$ is dan meer sprake van toezicht, evaluatie wan taken en feedback. Bij postmonitory control is er all sprake van crimineel gedrag en wordt achteraf iets gedaan: binnenskamers of strafrechtelijk. Reiss maakt een onderverdeling tussen het coöperatie-model (compliance) en het criminaliserings-model (deterrence) als vormen wan wetshandhaving. In beide modellen staat een preventieve werking van twee verschillende uitgangspunten centraal. Het coöperatie-model gaat uit van overleg tussen overtreder en controle-instantic. Het criminaliserings-model hanteert daarentegen sancties ter preventie van strafbaar gedrag. Toch bestaan in compliance-systemen ook straffen, niet om daadwerkelijk opgelegd te worden, maar voornamelijk als dreigement. Wordt er wel een straf opgelegd, dan is dat een teken dat het systeem ook gefaald heeft. ${ }^{69}$ Uit het onderzoek van Sherman bleek dat, indien de aanpassing van het beleid beperkt blijft tot het

65. Reisman, 1979 , p. 115 .

66. Sherman, 1978, p. 206.

67. Vgl. Van den Heuvel, 1993, p. 35 e.v.

68. Compliance systemen werken in die situaties waar potentiele overtreders gemakkelijk aan te wijzen zijn. Dat is het geval bij het controleren van organisaties, waarbij het echt gaat om het 'gedrag' van ondernemingen en niet om het gedrag van individuelen in die organisatie. Reiss, 1984, p. 29.

69. Reiss, 1984, p. 24. 
deterrence-model, andere wormen van corruptie al snel weer opnieuw beginnen. ${ }^{30}$

\subsubsection{Het verdere verloop van een schandaal}

Sherman stelt dat een schandaal in de meeste gevallen voorafgegaan wordt door een of meer kleinere voorvallen, die het imago niet hadden aangetast. Het kleinere voorval was wel in de openbaarheid gekomen, maar de ophef over de feiten was miniem gebleven. Het symptoom was bekend, maar de media vermoedden er geen gewoonte achter. Van een schandaal was dus geen sprake. Dat wil zeggen dat het imago en de geloofwaardigheid van de organisatie niet in gevaar zijn geweest. Voor de organisatie betekent dit dat er geen vervelende consequenties zijn, behalve dan dat de onthulling van het criminele gedrag de media getipt heeft over mogelijke mistoestanden bij die organisatie. Dit kan tot gevolg hebben dat die organisatie vervolgens grondig onderzocht wordt (bijwoorbeeld door de media), hetgeen kan leiden tot de onthulling van een groot schandaal. ${ }^{71}$

Dat een groot schandaal effecten kan hebben zoals verandering van wetgeving of beleid, ontslag of overplaatsing van personeel en het instellen van interne controlemechanismen, is met name te zien wanneer er geen andere vorm van externe controle alanwezig is. Indien bij een politie-organisatie dan iets fundamenteels in de situatie gewijzigd wordt, kan men wolgens Sherman. veronderstellen dat een schandaal of een andere gebeurtenis daarvan de oorzaak is geweest. ${ }^{72}$ Al bestaat er geen expliciete vorm van sociale controle, dankzij de media worden feiten onthuld die een gevaar zijn voor de goede naam van de organisatie. De top van de organisatie zal als gevolg, post- en/of premonitory controlesystemen in het leven roepen teneinde dit gedrag te bestraffen en in het vervolg te voorkomen.

70. Sherman, 1978, p. 226-241. Vgl. Braithwaite, 1984, p. 376-383. Ook Braithwaite is van mening dat controle van industrieèn (organisaties) beter verloopt via het proces van negotiation (compliance) dan door middel van legal compulsion (deterrence). Zie p. 378 .

71. Sherman, 1978, p. 207.

72. Sherman, 1978, p. 208; zijn stelling impliceert dus dat de politie-organisatie een zeer conservatieve organisatie is, die terugdeinst woor veranderingen. Hierbij wil ik wel opmerken dat de Amerikaanse politie van de jaren ' 70 niet noodzakelijk te vergelijken is met de Nederlandse politie van de jaren '70-'90. Allereerst zijn er verschillen in tijd en organisatie. Daarnaast zijn er veel culturele verschillen. Desalniettemin zijn de inzichten van Sherman woor deze studie nuttig. 


\subsection{Doelstelling en methoden van onderzoek}

Vanuit verschillende invalshoeken kan de probleemstelling van deze studie bekeken worden. De sociologie, filosofie, psychologie, politicologie, criminologie en organisatiekunde kunnen ieder afzonderlijk geïnteresseerd zijn in (een deel van) de probleemstelling. Het thema van problemen die de onafhankelijkheid van een organisatie met zich mee kunnen brengen is immers complex. Dit onderzoek is verricht vanuit een juridische en criminologische achtergrond. De kern van mijn vraagstuk is en blijft de problemen die kunnen ontstaan tengevolge van het ontbreken van verantwoordingslijnen van de politie naar maatschappij en politiek.

De theorie van Sherman die in dit boek uitgebreid aan de orde komt, is een sociologische organisatietheorie, maar deze richt zich met name op één soort organisatie: de politie. De onderhavige studie is in beginsel juridisch met sociologische aspecten. De vraagstelling van deze studie - het inzicht krijgen in de problemen van de onafhankelijkheid van het politieapparaat heeft immers veell raakvlakken met de sociologie.

Het is mijn uitgangspunt de gevolgen van de verantwoordingsstructuur en de onafhankellijkheidspositie van de politie weer te geven. Met de gevolgen duid ik woornamelijk op problemen die de onafhankelijkheid met zich mee kan brengen. Het onderzoek richt zich op de nieuwe regelgeving met betrekking tot het politieapparaat. Met name de ontwikkelingen op het gebied van de wetgeving staan daarbij centraal. De theorie van Sherman geeft het kader aan waarin ik de probleemstelling behandel. Op deze wijze hoop ik duidelijkheid te scheppen in de Britse politieorganisatie en aan te geven dat het controlevraagstuk een algemeen probleem is dat in alle organisaties kan voorkomen. ${ }^{73}$

Het onderzoek is derhalve deels beschrijvend en analyserend van aard. Daartoe wordt voornamelijk gebruik gemaakt van kwalitatieve onderzoeksmethoden. Kwalitatief onderzoek heeft zowel voor- als nadelen. Een algemeen bekend voordeel is dat dieper op de materie ingegaan wordt. Dit betekent vooral veel literatuur- en documentatie-onderzoek. Het documentatie-onderzoek omvat om die reden mede een bestudering van de - vrij betrouwbare - Engelse parlementaire stukken, wetten en jurisprudentie. Het grootste gedeelte van het literatuuronderzoek is verricht in 1992 en 1993. In dit onderzoek heb ik ook gebruik gemaakt - maar dan in mindere mate van observatie en interviews ${ }^{74}$, o.a. met de bedoeling de verschillende casus te actualiseren en inzicht te krijgen in de achtergronden van de casus.

73. Vgl. Reiss in Punch, Control in the Police Organization, 1983 (B).

74. Zie bijlage. 
Deze methode heeft als nadeel dat de onderzoeksresultaten uit observatie en interviews altijd worden beïnvloed door degene die bekijkt respectievelijk ondervraagt. Deze methode is derhalve niet vrij van subjectiviteit. De interviews zijn in het voorjaar van 1993 afgenomen.

De verschillende theorieën die ik behandel gebruik ik voornamelijk als theoretische achtergrond en niet zozeer ter toetsing of aanpassing. De methode die ik in deze studie hanteer is derhalve sterk eclectisch. Deze theorieën geven mijns inziens het beste de situatie weer en vullen elkaar aan. Tegen de achtergrond van de gehanteerde theorieën komen de praktijkgevallen duidelijker en sterker naar voren. 


\section{Engeland en Wales}

\subsection{Inleiding}

In de Inleiding heb ik de probleemstelling van deze studie in een theoretische achtergrond geplaatst. In het kader van dit hoofdstuk zal ik mijn probleemstelling nader invullen wat betreft Engeland en Wales, dat deel van Groot-Brittannie waar de aandacht in deze studie op gericht is. In de eerste plaats zal ik enkele begrippen nader definiëren. Daarna ga ik wat dieper in op het Engelse common law systeem, dat verschillen vertoont met het $\mathrm{Ne}$ derlandse systeem. Vervolgens wordt tegen deze achtergrond de Engelse politie geplaatst en ga ik na in hoeverre de theorie van Sherman die in het eerste hoofdstuk behandeld is, toe te passen is op de situatie in Engeland en Wales. Als laatste onderdeel van dit hoofdstuk bespreek ik in het kort de vijf casus, die elk afzonderlijk het onderwerp zijn van een hoofdstuk.

\subsection{Politie, gezag en onafhankelijkheid}

Onder de term "politie" 75 vallen verschillende politiediensten. In Engeland en Wales bestaan, evenals in Nederland, naast de reguliere politie andere diensten die politionelle taken verrichten. Gedacht kan worden aan militaire politie, aan douane-politie of aan spoorwegpolitie. Deze politiediensten worden in het kader van dit onderzoek buiten beschouwing gelaten. Hier gaat het enkel om de gewone politie in Engeland en Wales, i.e. vergelijkbaar met de Nederlandse regionale politie ${ }^{76}$, te bestuderen.

Wanneer ik spreek over "het gezag" over de politie, heb ik een tweetal punten voor ogen. ${ }^{77}$ In de eerste plaats bedoel ik de sturende invloed die uitgeoefend kan worden op het beleid van de politie. Dit is het preventieve toezicht. Daarnaast kan gezag slaan op het recht om verantwoording op te leggen aan de politie over gevoerd beleid of individueel politieoptreden. Deze vorm van gezag is het repressieve toezicht oftewel een element van controlle. In deze studie wil ik een onderscheid maken tussen het gezag dat van binnen en van buiten de politieorganisatie wordt uitgeoefend. Voor het

75. Reiner omschrijft politie als volgt: "The police are mainly a body of people patrolling public places in blue uniforms, with a broad mandate of crime control, order maintenance, and some negotiable social service functions. They are supllemented by non-uniformed adjuncts concerned primarilly with the investigation and processing of criminal offences and sundry administrative tasks.' Reiner, 1994, p. 716. Zie verder de beschrijwing van het begrip "politie" bij Boek, 1995, p. 31.

76. Zie 2.3.3.

77. Zie ook Van der Vijver, 1980, p. 6-8. 
gezag dat van buiten de politieorganisatie wordt uitgeoefend bedoel ik zowel de politieke als de rechterlijke werantwoordingsmogelijkheden. Bij de politieke verantwoordelijkheid zijn de rol en invloed van centrale en lokale overheden bellangrijk. De betekenis van de rechterlijke controle ligt voor de hand: toetsing door rechterlijke instanties van het optreden van de politie. Wat betreft de interne verantwoordelijkheid stat de vraag centraal of de interne controle een woldoende waarborg biedt tegen misbruik van individuele politiemensen en van groepsgedrag.

In deze studie staat de onafhankelijkheid van de politie centraal. Ook over deze "onafhankelijkheid" moet hier duidelijkheid bestaan. De politiekorpsen in Engeland en Wales zijn 43 onafhankelijke organisaties. Aan het hoofd van ieder korps staat een hoofdcommissaris. Officieel zijn deze hoofden van politie eigen bazen. Ook onderling bestaat er geen gezagsverhouding tussen de hoofdcommissarissen. De politie is derhalve onafhankelijk in die zin dat zij van niemand bevelen ontwangt en aan niemand - behalve alan de wet verantwoording hoeft af te leggen. Externe controle is formeel niet mogelijk. Controle vindt dan ook alleen intern plaats via hiërarchische lijnen. Zelfs de klachtenprocedure kan beschouwd worden als een interne vorm van controle, omdat dan de eigen collega's van de agent tegen wie de klacht gericht is, op bevel van de hoofdcommissaris (of zijn assistent), het onderzoek naar de gegrondheid wan de klacht verrichten. Met andere woorden een onderzoek naar klachten wordt niet zoals in Nederland door een externe instantie (de Rijksrecherche) uitgevoerd.

\title{
2.3 Common law - continental law
}

\begin{abstract}
'Bij vergelijking van de Anglo-Amerikaanse proceswoering met de EuropeesContinentale dient allereerst te worden bedacht, dat een systeem soms het betere kan zijn, omdat men ermee heeft leren leven en werken. Een proces dat naar de verschijningsvorm meer inquisiroir is kan - en dar acht "k een niet te onderschatten voordeel - serener verlopen dan een meer accusatoir geding. waarin partijen - zij het in fair play - elkaar bevechten. De witslag wan de accusatoire procedure wordt eerdter bepaald door de alertheid en gevatheid wan de vervolgende of verdedigende madslieden dan door de merites van de zaak zelf. De rechter zal zich in een inquisitoire situatie wel voordurend het door Glanville Williams gesignaleende gevar van rolverwarring dienen re realiseren maar als hem dit mede door zijn opleiding, ervaring en woral onafhankelijkheid mogelijk is, acht ik het naar de verschijningsworm inquisitoire proces niet inferieur aon het meer accusatoire. ${ }^{.78}$
\end{abstract}

Voor een goed inzicht in het Engelse politieapparaat en zijn achtergronden is het wenselijk even stil te staan bij het strafrechtsysteem in Engeland en Wales en het te vergelijken met het strafrechtsysteem op het continent. Het 
strafrechtsysteem In Engeland en Wales verschilt van het systeem op het vasteland. Het systeem in Engeland en Wales wordt gekenmerkt door het common law-stelsel, dat op het vasteland door het continental law-stelsel. Bij het common law-stelsel staat het accusatoire proces woorop. ${ }^{79}$ Op het continent ligt er meer nadruk op de inquisiroire procesvorm.

De begrippen 'inquisitoir' en 'accusatoir' zijn complex. Ze zijn niet in een eenvoudige definitie te vatten. Van oorsprong geeft een accusatoir proces aan dat een proces begonnen is op grond van een klacht van een partij. Zonder klacht, geen proces. Alle processen, dus ook strafprocessen, waren een private aangelegenheid. Bemoeienis van de overheid was er niet ${ }^{80} \mathrm{Op}$ een gegeven moment nam de overheid de vervolgingstaak van strafbare feiten over en breidde die uit met ook al die zaken, waarbij geen klacht was ingediend. Die uitbreiding bood gelegenlheid tot het ontstaan van de meer inquisitoire procesvorm. Met de komst van het inquisitoire proces is de ro» van de klager en slachtoffer meer op de achtergrond geraakt. Binnen deze inquisitoire vervolgende overheid werden de termen accusatoir en inquisitoir later opnieuw geintroduceerd. Met accusatoir werd toen bedoeld '... de gelijk gerechtigdheid van den beklaagde met den aanklager, alsook de lijdelijkheid van den rechter ... ${ }^{81}$ Inquisitoir hield in dat de rechter actief betrokken was bij het vooronderzoek en het onderzoek ter terechtzitting.

In de memorie van toelichting op ons huidige wetboek van strafvordering lezen we dat de Nederlandse overtheid uitdrukkelijk gekozen heeft voor een gematigd accusatoir strafproces. ${ }^{82}$ In het inquisitoire strafprocesrecht wordt

79. Zie o.a. Zander, 1988, p. 292; Royal Commission on Criminal Justice, 1993, p. 3-4.

80. Drenth, 1939, p. 236; Jörg/Kelk, 1994, p. 203-206; Van de Vrugt, 1992.

81. Drenth. 1939, p. 238; Jörg/Kelk, 1994, p. 205-206; Royal Commission on Criminal Justice, 1993, p. 3.

82. Memorie van Toelichting. \$3, in: Hendriks, Klifman, Mols, De Roos en Wöretshofer, 1992. Volgens. Drenth hadden we in 1939 in Nederland echter geen lijdelijke rechter, had de verdachte nog steeds niet dezelfde rechten als het Openbaar Ministerie, en werd de vervolging niet aan particulieren overgelaten. Kijken we zuiver naar de definitie van accusatoir dan moeten we concluderen dat Nederland een inquisitoir strafstelsel bezat. Drenth, 1939, p. 242-243. De conclusie van Drenth in zijn proefschrift was dat men aan de termen accusatoir en inquisitoir kenmerken toeschrijft die geheel voorbijgaan aan de oorspronkelijke betekenis. Nijboer geefl aan dat verschillende rechtssystemen ook de nadruk kunnen leggen op andere waarden. De Amerikanen benadrukken het adversarial-element sterk. Nederland heef in hun ogen derhalve een zuiver inquisitoir systeem. Wij benadrukken zelf echter weer andere aspecten van een accusatoir proces, zoals gelijke rechten woor partijen. Door dit verschil in benadering 
uitgegaan van de verdachte als onderzoeksobject ${ }^{83}$ en in het accusatoire proces van twee gelijkwaardige partijen. De Engelse term omschrijft mijns inziens het laatste systeen op een meer heldere wijze. De Engelsen spreken namelijk van een adversarial system, een proces op tegenspraak, gericht op conflictregulering. Kijken we naar de rol van de rechter, dan zien we dat deze in de twee verschillende systemen niet gelijk is. In het inquisitoire proces is de rol van de rechter actief en de rechter leidt het onderzoek, in het accusatoire systeem is de rol van de rechter passiever. ${ }^{85}$ In beide systemen gaat het in principe om de waarheidsvinding ${ }^{86}$ De manier waarop dat gebeurt verschilt. Juist in het adversarial systeem zien we dat vaak een enkele bekentenis voldoende is voor een veroordeling. ${ }^{87}$ Corroborative evidence $^{88}$ is dan niet nodig. ${ }^{89}$

Het lijkt vreemd dat in Europa twee verschillende processystemen gegroeid zijn. Beide modellen zijn immers ontstaan in nagenoeg gelijksoortige staten. Het systeem op het continent is in de meeste landen daar, op kleine details na, gelijk. Het strafproces in Engeland en Wales verschilt op een aantal punten echter drastisch van het systeem op het continent. Wat zijn de achtergronden van dit verschil en waarom hebben we in de loop der tijd geen wijziging gezien van het ene systeem in het andere?

82. $\rightarrow$

van systemen lijken we in de ogen van de Amerikanen veel meer inquisitoir dan wijzelf menen. Nijjboer, 1992, p. 9-10.

83. Van Bemmelen, Van Veen, 1989, p. 24.

84. Inclusief facetten als plea-bargaining en het proberen een zaak echt te winnen, in plaats van een verdachte te laten veroordelen.

85. Jörg/Kelk, 1994, p. 38-39; zie ook Brants, 1994, p. 28; Corstens, 1993, p. 7.

86. Elk systeem zal altijd kenmerken van beide modellen vertonen, want anders valt er bijna niet in alle redelijkheid mee te werken: "Blijft de verdachte volledige procespartij bijw. door hem aan geen enkel dwangmiddel in het voorbereidend onderzoek te onderwerpen, dan wordt de waarheidswinding te veel bemoeilijkt en de bewijswoering in een aantal gevallen onmogelijk gemaakt. Wordt daarentegen de positie van de verdachte als procespartij genegeerd, dan dreigt het strafproces onmenselijk te worden." Mellai, art. 29, aant. 2.

87. Zoals we zullen zien bij enkele van de IRA-zaken, waarover later.

88. Dit wil zeggen dat ander bewijsmateriaal vereist wordt om de bekentenis te onderstetunen.

89. Zie o.a. Brants, 1994, p. 28. 


\subsubsection{Damaška}

Damaška heeft in zijn boek The Faces of Justice and Siate Authority ${ }^{\circ 0}$ getracht de achtergronden van het verschil tussen het accusatoire en het inquisitoire proces duidelijker te maken aan de hand wan de structuur van de regering en van de functie van de regering in de maatschappij. ${ }^{12}$ De verschillen tussen de beide procesvormen zijn volgens hem te verklaren door enerzijds de wijze waarop de gezagsstructuur geregeld is en anderzijds de invloed van de rol van de regering op de procedures. Bij de structuur heeft Damaska de bureaucratie voor ogen en maakt hij een onderscheid tussen een hiërarchisch ideaal en een coördinatie ideaal. Bij de functie moet gekeken worden of het doel van de regering is het oplossen van conflicten of het sturen van beleid. Damaška kwam tot de conclusie dat zowel structuur als functie invloed hebben op het proces. Een coördinatie-structuur hoort bij een conflictoplossing als doel, en een hiërarchische structuur hoort bij beleidssturing als doel. Bij de eerste combinatie past het adversarial system en bij de tweede combinatie past het inquisitoire systeem. In de praktijk bevat elke staats- en regeringsvorm elementen van zowel een hiërarchie- en als van een coördinatiemodel. Damaška heeft combinaties van modellen uitgewerkt. Zoals gezegd kan worden dat een regering zowel de burgers met rust will laten als zich met hem wil bemoeien om een zeker beleid uit te stippelen, zo zullen de meeste strafprocessystemen met elementen van beide modellen verweven zijn. ${ }^{92}$

\subsubsection{De systemen in Nederland en Engeland en Wales}

In Nederland heeft men geopteerd voor het gematigd accusatoir proces. ${ }^{93}$ De rechter kan niet op eigen initiatief tot een onderzoek of een veroordeling overgaan, maat moet de vordering van het Openbaar Ministerie afwachten. Dat is niet zuiver accusatoir, omdat in een zuiver systeem verdachte en OM. als zelfstandige partijen zouden optreden. Ons vooronderzoek is voornamelijk inquisitoir ${ }^{94}$ Hier kán de rechter-commissaris zijn onderzoekende rol

90. Damaška, 1986.

91. Damaška, 1986 , p. 8-15.

92. Damaška, 1986, p. 12.

93. Of gematigd inquisitoir. Dat is afhankelijk wan het feit of men op het wooronderzoek of op het onderzoek ter terechtzitting de meeste nadruk legt. Zie de Memorie wan Toelichting bij het Ontwerp Wetboek van Strafvordering, zitting 1912-1913, met name $\$ 3$.

94. Hendriks, Klifman, Mols, De Roos, Wöretshofer, 1992, MvT, p. 33-35; Jörg/ Kelk, 1994, p. 39, 203-206. 
vervullen. Aangezien men zekere rechten van de verdachte ${ }^{95}$ in het oog houdt, kan men spreken van een gematigd inquisitoir vooronderzoek.

Het strafrechtsysteem in Engeland en Wales is accusatoir. Met de komst van de Police and Criminal Evidence Act 1984 (hierna PACE genoemd) kan men stellen dat het vooronderzoek iets minder accusatoir geworden is. De verdachte moet sindsdien meer handelingen dulden. Toch bezit het systeem nog genoeg kenmerken om het als adversarial system te typeren.

\subsubsection{De politie in Engeland en Wales}

Na deze korte schets van beide procesvormen wil ik enkele eigenaardigheden van de politie in Engeland en Wales schetsen, om daarmee aan te geven dat de politie op de Britse eilanden van andere wooronderstellingen en premissen uitgaat dan de politie op het continent. Het is tegen de achtergrond van het adversarial system dat de politie in Engeland en Wales haar eigen karaktertrekken gekregen heeft. Hieronder schets ik die karaktertrekken de politie van Engeland en Wales in grote lijnen en stel die tegenover de politie in ons eigen land.

95. Het kennisnemen van stukken, de aanwezigheid van een advocaat, de rechten van de verdachte in een Huis van Bewaring etc. 
De politie in Engeland en Wales is onafhankelijk en autonoom. Agenten zijn slechts verantwoording schuldig aan hun superieuren ${ }^{\text {s6 }}$ en aal de wet. Directe parlementaire controle is bijna niet moge1ijk. ${ }^{97}$ De controle door de platselijke politiecommissie is beperkt tot het stellen wan vragen aan de hoofdcommissaris over het beleid. Over het uitvoeren van het politiebeleid, d.w.z. hoe het beleid in de praktijk toegepast wordt, kunnen geen vragen gesteld worden.

De bewoners van de Britse eilanden zijn afkerig van een nationale politie. ${ }^{98} \mathrm{De}$ vrees dat de politie de macht grijpt, zit diepgeworteld in de Engelse maatschappij en stamt nog uit de Napoleontische tijd, toen er in Frankrijk onder leiding van de regering een politieapparatat was, waar spionnen deel van uitmaakten.

Elke agent moet onderaan de ladder beginnen. Wat dat betreft maakt het niet uit welke opleiding de aspirant-agent genoten heeft. Elke agent volgt ook dezelfde stappen bij de promotic naar een hogere functie. In bepaalde gewallen is wel een universitaire graad aanbevolen. Vanaf het begin van zijn loopbaan komt de agent vaak de politiedenkbeelden bijgebracht. ${ }^{99}$
De politie in Nederland is uiteindelijk werantwoording verschuldigd an het parlement via de ministers van Justitie en wan Binnenlandse Zaken.

Controle door de burgemeester en de gemeenteraad is mogelijk over ordehand havingsuraagstukken. Voor de wetshandhaving is de Officier wan Justitie het con" trolerend orgaan. Er zijn dus steeds twee bazen.

In Nederland kent sinds 1994 regionale politiekorpsen.

Het feit dat de politie ook in de nieuwe politiewet onder de politieke verantwoording staat van twee ministers wil uitdrukking zijn van afkeer van te grote macht.

Afgestudeerden van de Nederlandse Politie Academie kunnen hoog in het politieapparaat binnenstromen. Zonder een bepaalde vooropleiding via de politieschool konden agenten woorheen niet bo* ven een bepaalde rang uitkomen. Tegenwoordig is dat - in geringe mate - wel mogelijk.

96. Het komt woor dat een agent een bevel van een hoofdcommissaris naast zich neerlegt en op eigen initiatief een zaak doorzet. Zonder consequenties!

97. Het instellen van verschillende Royal Commissions in de loop der jaren laat zien dat het parlement de mogelijkheid heeft de regering te 'dwingen' iets te ondernemen. Een Royal Commission is vergelijkbaar met een enquêtecommissic.

98. Tot de Eerste Wereldoorlog was de rol van de staat in het leven van de Engelsman te verwaarlozen. De Engelsman had geen paspoort nodig en hoefde niet in militaire dienst. Hij kon opgeroepen worden on in een jury plats te nemen, maar kon dit maast zich neerleggen. Hij moest alleen belasting betalen, maar ook dat was - in vergelijking met de huidige tariewen - een schijntje. De Engelsman was derhalve niet gewend dat de staat macht had over zijn onderdanen. Taylor, 1970 . p. $25-26$.

99. De jonge recruten krijgen dus al gauw te maken met de politiecultuur, die de buitenwereld afsluit. Dit versterkt het loyaliteitsgevoel tegenover elkaar. In Engeland en Wales is dat nog sterker dan in Nederland het geval. 


\subsubsection{Geschiedenis}

De structuur van het Britse strafrechtsysteem kan niet los gezien worden van de geschiedenis van Groot-Brittannie door de eeuwen heen. Terwijl op het vasteland in de verscheidene landen de invloed van elkaars politiek en staatsinrichting duidelijk merkbaar is, staat Groot-Brittannië alleen met zijn eigen common law-systeem. Groot-Brittannie heeft weinig irvasies gekend. Afgezien vari de grote invallen van de Romeinen in het begin van de jaartelling en de Noormannen in de elfde eeuw is er nooit meer een grote inbreuk geweest. Buitenlandse invloed die getorceerd opgelegd werd, was er praktisch niet. Groot-Brittannië had een machtig koninklijk huis, kende een degelijke vloot, had grote koloniën en was tot het begin van deze eeuw éen van de grootste wereldleiders. Daarnaast kende Groot-Brittanniẻ geen revolutie. De overheid was nooit een machtig apparaat en was bovendien sterk gedecentraliseerd. Het is daarom geen wonder dat de Britten trots zijn op hun land en hun geschiedenis. Dat geldt ook voor hun strafrechtsysteem en hun politie.

\subsubsection{Afronding}

Common law landen als Engeland en Wales kennen een andere procesvorm dan Nederland. De oorzaak van dat verschil zal ik niet behandelen en is in de context van deze studie niet relevant. Daarnaast hebben Engeland en Wales een unieke geschiedenis: weinig invasies, geen politieke revolutie, een rijk koloniaal verleden en een sterk gedecentraliseerde overheid, geen geschreven wet. Deze aspecten staan garant voor een onafhankelijk georganiseerde politie. Tegen deze achtergrond moet derhalve de onafhankelijkheid van de politie gezien worden, met name de onwil om het systeem te veranderen of vreemde, continentale systemen in te voeren.

\subsection{Is de theorie van Sherman ${ }^{100}$ toepasbaar op de politie in Enge- land en Wales?}

Sherman behandelde in zijn boek corruptie van de politie in vier steden in de Amerikaanse samenleving op een bepaald moment. ${ }^{101}$ Zowel het voor-

100. In de Verenigde Staten van Amerika is veel (sociologisch) onderzoek gedaan naar het functioneren van diverse organisaties (waaronder de politie). De Amerikaanse literatuur overheerst op dit terrein de Britse/Europese literatuur. Dat is mede de reden dat ik voor mijn onderzoek naar de politie in Engeland en Wales een Amerikaanse theorie heb gebruikt.

101. New York City, Oakland (California), Newburgh (New York) en een anonieme vierde stad, Central City (waarschijnlijk Chicago). Zie ook hierover Punch, 1985 , p. $15-17$. 
komen van corruptie bij prostitutie, gokken en drugs - i.e. het zich laten betalen door het dulden van deze wormen van criminaliteit - als corruptie in de vorm van het georganiseerd inbreken, heeft hij nader bekeken. Hij onderzocht de oorzaak van de corruptie en de situatie voor de ontdekking van deze corruptie en vergeleek dit met de situatie na het corruptieschandaal. Zijn specifieke aandachtspunt was of de herwormingen die de leiding van de politie en van de stad doorgevoerd hadden op het terrein van de controle en het toezicht, enig effect gesorteerd hadden.

In tegenstelling tot de aanpak van Sherman die naar vier politiekorpsen in de Verenigde Staten van Amerika gekeken heeft, is deze studie gericht op alle politiekorpsen in Engeland en Wales. De politie in Engeland en Wales bestaat feitelijk uit 43 aparte politiekorpsen. Door de wijze warop alle korpsen georganiseerd zijn en onder financiële leiding staan van het Home Office, lijkt het alsof deze 43 korpsen tot één politieapparaat behoren. Bovendien kijk ik niet naar een bepaald moment, maar bestudeer ik de ontwikkelingen binnen de organisatie van de politie over een periode van bijna 40 jaar. Daarmee hoop ik dan in staat te zijn aan te tonen dat ook deze ontwikkelingen gekenmerkt worden door scandal en reform.

Het lezen van de geschiedenis van de politie in Engeland en Wales heeft mij geleerd dat de meeste wijzigingen op het gebied van de politiewetgeving ontstaan zijn na aanbevelingen en voorstellen tot wijzigingen van de bestaande wetgeving door verscheidene commissies. Deze commissies waren ingesteld nadat door de regering problemen bij de politie gesignaleerd waren. De veranderingen zijn via wetswijziging tot stand gekomen en de voornaamste wijzigingen zijn te vinden in de wetten: Police Act 1964, Police Act 1976, Police and Criminal Evidence Act 1984 (PACE) en de Prosecution of Offences Act 1985. Wat dat betreft zou ik een duidelijk verband willen leggen tussen deze problemen en de uiteindelijke wetswijzigingen. Het is niet zo dat deze problemen los van elkaar staan. Alle problemen hebben het gemeenschappelijke kenmerk dat zij ontstaan zijn vanwege het ontbreken van een directe politieke controle over de politie. Directe politieke controle is in Engeland en Wales niet mogelijk op lokaal en op centraal niveau. Het verantwoordings- en controleprobleem loopt dan ook als een rode draad door deze studie. Het gaat daarbij zowel om het ontbreken daarvan, als om de pogingen van politiecommissies en het parlement een bepaalde vorm van zeggenschap te behouden respectievelijk te verkrijgen over de politie.

In het geheel van problemen en hervormingen meen ik een systematiek te herkennen, in die zin dat het ontstaan van een probleem (of strafbaar feit etc.) voortvloeit uit de oplossing (of hervorming, wetswijziging) die de regering voorgesteld heeft naar aanleiding van een eerder probleem. In de 
natururwetenschappen wordt een dergelijke systematiek aangeduid met de term 'perpenum mobile".

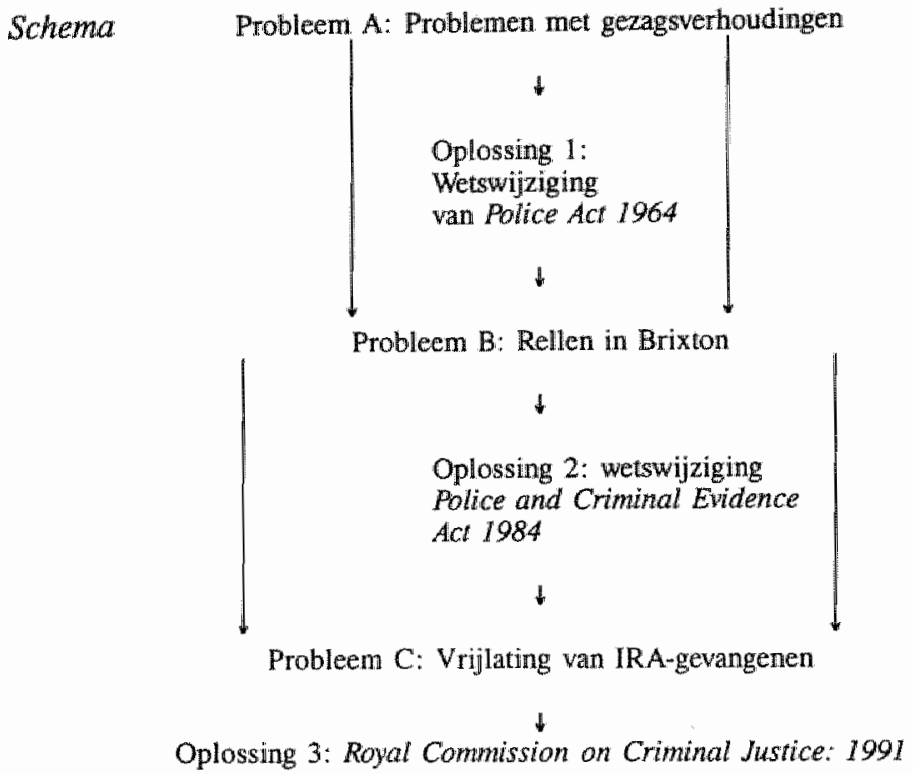

Met dit schema ${ }^{103}$ wil ik aangeven dat probleem A geleid heeft tot oplossing 1, maar tevens samen met oplossing 1 aanleiding is geweest woor probleem $B$. De wetswijziging van oplossing 1 heeft voor een deel slechts de knelpunten van probleem A weten te verhelpen, maar is daarnaast deels verantwoordelijk voor een nieuw probleem (B). Wetswijziging lost niet alles op. Men loopt als het ware steeds achter de feiten aan, aangezien de maatschappij woortdurend ontwikkeit.

Ik wil nog een stap verdergaan en stellen dat dertig jaar veranderingen in wetgeving en beleid met betrekking tot de politie in Engeland en Wales de oorspronkelijke problemen niet wezenlijk hebben opgelost. Derhalve zou ik de voorspelling kunnen doen dat de laatste wetswijziging weer niet definitief de problemen zal oplossen en dat na een aantal jaren weer een schandaal zal opduiken. Maar zover wil ik niet gaan. Shermans stellingen hebben het uiterlijk van een 'ijzeren wet', maar vinden hun begrenzingen in het conser-

102. In de sociologie zou de benaming eerder control ycles zijn.

103. Het schena, is, zoals het woord al zegt, een afspiegeling wan de werkelijkheid. een vereenwoudigde weergave. 
vatisme $^{104}$ van de politieorganisatie en in de vraag of een meer democratische en controleerbare politie denkbaar en halbaar is. ${ }^{103}$

\subsection{Vijf casus}

In het voorgaande is de theorie van schandaal en hervorming besproken en de toepasselijkheid hiervan op de Engelse situatie aan de orde gekomen. De onafhankelijkheid komt naar voren in het ontbreken van politieke verantwoordingslijnen. Voor de Britten lijkt het geloof in de sincerity van de politie en in de rule of law voldoende waarborgen te bevatten tegen mogelijk misbruik door de politie.

\subsubsection{Vertrouwen}

Bij een organisatie als de politie in Engeland en Wales die grotendeels onafhankelijk is, speelt het vertrouwen van de burgers in de politie een cruciale rol. In een rechtsstaat verricht de politie haar taak met instemming van de burgers: policing by consent. ${ }^{106}$ Het vertrouwen gat aan die instemming vooraf. Een organisatie die het vertrouwen van de gemeenschap is kwijtgeraakt, heeft geen gezag of legitimiteit ${ }^{107}$ meer. De legitimiteit heeft betrekking op het algemene beleid van het instituut en niet op specifieke politiebeslissingen. Instemming kan op verschillende manieren benaderd worden: politiek, wettelijk en sociaal (burgers). De politieke en de sociale instemming zija de laatste decennia niet altijd volledig geweest. In de politiek zien we dat er vanuit de Houses of Parliament een duidelijke roep is om controle over de politie. Het gebrek aan sociale instemming kan men aflezen aan het feit dat de burger de politie bij haar taak minder vaak assisteert of terzijde staat (weinig bereidheid tot aangifte of tot getuigenissen). ${ }^{10}$ "It follows that the police, in exercising their functions, are, to a peculiar degree, dependent upon the goodwill of the general public and that the utmost discretion must be exercised by them (i.e. de politie, CR) to avoid overstepping the limited powers which they possess. A proper and mutual understanding between the police and public is essential for the maintenance of law and order: 109

104. Zie ook Reiner, 1985, p. 97-99. In Engeland zijn er op het ogenblik grote weranderingen gaande zowel extern (management) als intern (taakopvating).

105. Sinds Sherman is er veel nagedacht over het controleren van het politieapparaat, zowel in Engeland en Wales als in Nederland.

106. Morgan, in Morgan and Smith, 1989, p. 217.218.

107. Waarmee ik bedoel: reden tot juridisch bestaan.

108. Morgan, 1989, p. 219-220.

109. Royal Commission on the Police, 1962, p. 11: citalit overgenomen van het Repon van de Royal Commission on Police Powers and Procedure, 1929. 


\section{5 .2 Klachten}

Wanneer er een ernstige klacht is, bijvoorbeeld mishandeling, dan wordt die klacht, volgens de nu bestaande procedure, door agenten van een ander politiekorps onderzocht. Dit laatste moet waarborgen dat de klacht onafhankelijk onderzocht wordt. ${ }^{100}$ Het onderzoek kan uitmonden in een disciplinaire sanctie, maar het kan ook zijn dat er niets gebeurt. Heeft het onderzoek voor de klager en voor andere betrokkenen geen tevreden resultaat tot gevolg, dan kan het gebeuren dat via het eigen parlementslid in het Lagerhuis vragen gesteld worden aan de minister van het Home Office. ${ }^{\prime \prime \prime}$ In dat geval wordt het optreden van de politie veel pregnanter in het openbaar aan de kaak gesteld. Een dergelijk gebeurtenis is natuurlijk niet goed woor het imago van de politie.

Bepaalde gebeurtenissen in de afgelopen jaren hebben dat vertrouwen op momenten aangetast. Doch steeds niet voor langere tijd. Uiteindelijk blijken veel Britten hun strafrechtsysteem, inclusief de politie, nog altijd het beste van de wereld te vinden. ${ }^{112}$ Desondanks is er zo nu en dan iets mis gegaan en zijn er zaken veelvuldig in de publiciteit gekomen.

\subsubsection{Verantwoording en methode}

Aangezien het in dit boek gaat over onafhankelijkheid van de politie en de verantwoording aan het parlement heb ik getracht voorbeelden in de Engelse praktijk te vinden die daarbij aansluiten. Om praktijkgevallen te vinden heb ik de handelingen van het House of Commons vanaf 1955 bestudeerd. ${ }^{113}$ Ik heb de Engelse kamerstukken als belangrijkste bron genomen vanwege de betrouwbaarheid van de informatie. De kamerstukken zijn een waarborg voor nauwkeurigheid van informatie. Ook kan men redelijk afgaan op de juistheid van de gegeven informatie. Op deze wijze kon ik schandalen die allereerst in de landelijke pers naar voren kwamen screnen op "belangrijkheid' en 'omvang van de maatschappelijke onrust'. Aanhoudende onjuiste geruchten in de tabloids kon ik op deze manier omzeilen. De trefwoorden

110. Maar kritische geluiden geven aan dat de klachten door een externe dienst of organisatie onderzocht zouden moeten worden.

111. Men zou kunnen aanvoeren dat hier sprake is van parlementaire controle, een positief iets. Chris Mullin geeft echter in het interview aan dat die controle niet veel voorstelt. Zie bijlage.

112. Mensen zijn over het algemeen positief over de politie. Vgl. Van der Vijwer, 1993, p. 111, 123.

113. Om precies te zijn vanaf volume 537, 5th Series van de T.C. Hansard, The Parliamentary debates from the year 1803 to the present time. Dit wordt verder geciteerd als 537 H.C. Deb., Sth Series, kolom 2217 e.v. 
aan de hand waarvan gezocht is, zijn: accountability, police, police abuse, prosecution, complaints, royal commission, miscarriage of justice, riots. Deze studie heeft ertoe geleid dat ik vijf - naar mijn mening - belangrijke gebeurtenissen kon ontdekken, die langere tijd de aandacht van het parlement hebben gekregen. Als criterium heb ik een periode van vijf jaar of meer gehanteerd. Dit tijdsbestek onvat de ontdekking van het schandaa $\rrbracket_{\text {, het }}$ instellen van een werkgroep of commissie en een eventuele wetswijziging. Gebeurtenissen korter dan deze tijd zijn dan te omschrijven als incidenten. Op deze wijze kon ik de grotere 'schandalen' onderscheiden van de in verhouding kleinere incidenten.

De casus houden verband met wetswijzigingen: Police ACt 1964, Police Act 1976, Police and Criminal Evidence Act 1984 en Prosecution and Offences Act 1985. De vier gebeurtenissen die de aanleiding zijn geweest tot deze wetswijzigingen worden hier besproken. Bovendien behandel ik het recente schandaal van de miscarriages of justice, dat geleid heeft tot de instelling van de Royal Commission on Criminal Justice. Onder de noemer van miscarriages of justice worden verschillende gevallen besproken.

Literatuur- en jurisprudentieonderzoek en interviews verschaften mij de verdere noodzakelijke informatie. Helaas zijn veel rapporten over de vijf gebeurtenissen (nog) geheim. Dit betroffen dan voornamelijk politieonderzoeken. Ook als een zaak sub judice is, dus 'aan het oordeel van de rechter onderworpen', is men in Engeland zeer terughoudend met het verstrekken van informatie. Dit speelde vooral bij de laatste casus een rol.

\subsubsection{Vijf schandalen}

Teneinde de dynamiek van schandaal en hervorming binnen de ontwikkeling van het Britse politieapparaat aan te tonen, wil ik een vijftal gebeurtenissen. beschrijven waaruit die dynamiek naar mijn mening blijkt. Al de gevallen hebben veel publiciteit teweeggebracht in Engeland en Wales. De oorzaken van de gebeurtenissen waren ook (maar niet alleen) in alle gevallen terug te leiden naar de politie. Daarnaast zijn deze gevallen ook essentieel voor een volledige beschrijving van de ontwikkeling van de onafhankelijkheid en de controle over de politie in Engeland en Wales.

Enkele gevallen lopen, wat het tijdsbestek betreft, in elkaar over. Zij bestrijken in alle gevallen een periode van nagenoeg tien jaar. Uit de periode van tien jaar blijkt dat reacties op schandalen tijd nodig hebben. Ik heb getracht zoveel mogelijk de chronologie van de schandalen in stand te houden, al is dat met de laatste casus niet gelukt. Daar speelde het voorval zich af rond 1974, terwijl de onthulling van het schandaal eind jaren tachtig was. Elke casus heeft ook een naam gekregen, meestal de directe aanleiding wan het schandaal. Ik heb getracht zowel het schandaal, de reactie van pers en parle- 
ment als de uiteindelijke wetswijzigingen te beschrijven. Dit is gedaan on in de afsluitende opmerkingen van dit deel na te gaan in hoeverre de wetswijzigingen beantwoordden aan de problemen die gesignaleerd waren bij de onthulling van de schandalen. Hierbij moet nog wel opgemerkt worden dat de structuur van de verhalen van de vijf gebeurtenissen niet geheel gelijk is. Bij de laatste casusbehandeling over de miscarriages of justice is het uiteindelijk resultaat nog niet bekend. Alhoewel ik verwacht dat de eerste wetswijzigingen eind jaren "90 ingevoerd zullen worden, heb ik ook in dit hoofdstuk niet geaarzeld al enige conclusies te trekken uit het schandaal en de aangekondigde herworming.

De eerste vier casus laten problemen zien bij delen van het strafproces. In deze zaken is sprake van machtsmisbruik, geweld, racisme en problemen miet de bewijsvoering. De vijfde "zaak" raakt het gehele strafrechtsysteem. De politie probeerde onder druk van de publieke opinie zaken onrechtmatigg rond te krijgen, maar ook bleek al gauw het forensisch bewijs onbetrouwbaar te zijn. Echter, de prosecutors, de rechters, de politiek en de hoger beroepsinstanties hebben te weinig gedaan om de zaak tegen te houden. De uit deze gevallen voortgekomen Royal Commission had dan ook de opdracht gekregen om naar het hele systeem te kijken.

\section{1) 1956-1964: Causes Célèbres ${ }^{114}$}

Dit betreft problemen tussen hoofdcommissarissen en politiecommissies, die uiteindelijk resulteerden in de Police Act 1964. De eerste incidenten ${ }^{15}$ die tot de wetswijziging geleid hebben vonden plaats in de jaren 1956-1957 in Cardiganshire, Brighton, Worcester en Nottingham. Deze incidenten waren de aanleiding voor vragen in het Lagerhuis betreffende het ter verantwoording roepen van de politie.

\section{2) 1976-1984: De dood wan Blair Peach}

Burgers met klachten over de politie vonden in de klachtenprocedure geen instantie die onafhankelijk de klachten onderzocht: de oprichting van de Police Complains Board (1976) en de Police Complaints Authority (1984). Sinds de inwerkingtreding van de Police Act 1964 werden in het Lagerhuis vragen gesteld over de wenselijkheid van een onafhankelijk element in de klachtenprocedure. In 1976 werd deels aan deze eis toegegeven. Nadat in 1979 twee personen, waarvan én Blair Peach heette, op politiebureaus de dood vonden werd het systeem in 1984 gewijzigd.

114. Term 0.a. afkomstig uit Reiner, 1985, p. 143.

115. Deze term gebruik ik hier niet als het tegenovergestelde van schandaal. 


\section{3) 1980-1984: Brixton-rellen}

De Brixton-rellen, waarbij kleurlingen in april 1981 massaal in opstand kwamen tegen de politie, schokten heel Engeland en Wales. Lord Scarman werd verzocht een onderzoek naar de rellen in te stellen. Naar aanleiding van dit rapport en van het rapport van de Royal Commission on Criminal Procedure kwam de Police and Criminal Evidence Act 1984 tot stand.

\section{4) 1972-1985: De Confait-zaak}

Klachten over politieoptreden: Prosecution of Offences Act 1985. In 1975 werden de veroordelingen van drie jongens vernietigd. Op grond daarvan werden een Fisher-commissie en een Royal Commission ingesteld om te onderzoeken in hoeverre veranderingen nodig waren o.a. op het gebied van de opsporing en de vervolging. De laatste commissie adviseerde de vervolging van strafbare feiten niet meer in handen te leggen van de politie.

\section{5) 1974-1992: Miscarriages of Justice}

Als laatste gebeurtenis komen de zaken aan de orde van verschillende groepen leren, wier veroordelingen vanaf 1989 vernietigd werden. In deze zaken werd veelvuldig gebruik gemaakt van het afdwingen van bekentenissen. Was dit routine, met andere woorden te wijten aan het systeem, of waren het fouten van individuele agenten? Deze gebeurtenissen zijn recent en hebben veel opschudding teweeg gebracht zowel in Groot-Brittannië als daarbuiten. ${ }^{116}$ De instelling van de Royal Commission on Criminal Justice (1991) was een rechtstreeks gevolg van deze vrijlatingen. De commissie rapporteerde medio 1993. Het gehele rechtssysteem werd door de commissie onder de loep genomen.

\subsection{Opret}

In het eerste deel van deze studie komt de geschiedenis en organisatie van het politieapparaat tot de jaren '60 aan de orde. Teneinde inzicht te krijgen in het huidige politieapparat en in de verschillende rangen binnen het politiekorps in en buiten Londen, bespreek ik vervolgens de organisatiestructuur van de politie in Engeland en Wales.

Vervolgens worden vijf 'schandalen' behandeld. In elk hoofdstuk van dit deel staat een schandaal in het middelpunt. De gevolgen van en de reacties op de schandalen worden hier uitgewerkt. Het gaat stuk voor stuk over gebeurtenissen die van grote betekenis waren voor de ontwikkelingen op het gebied van de onafhankelijkheid van de politie. Waar mogelijk zal ik trachten een analyse van deze ontwikkelingen tijdens deze periode te geven. Dit

116. Vgi. de film 'In the name of the father' van Jim Sheridan over the Guidford' Four. 
gebeurt aan de hand van de theorieën van Sherman en van Reisman. Daarbij komt aan de orde wat het doel van de voorgestelde aanbevelingen en wetswijzigingen is. Bovendien wordt dan bekeken of een hervorming wel een echte hervorming genoemd kan worden.

In deze studie is mijn aandacht voornamelijk uitgegaan naar de situatie in Engeland en Wales. Mijn probleemstelling gaat immers over de onafhankelijkheid van de politie in Engeland en Wales. Desalniettemin maak ik in het laatste gedeelte van mijn studie een uitstapje naar Nederland. In het Nederlandse gedeelte behandel ik de recente reorganisatie wan de politie en bespreek ik twee gebeurtenissen, waaraan ik in navolging van de gehanteerde terminologie in het gedeelte over Engeland en Wales ook het etiket "schandaal' op geplakt heb.

Het is niet mijn bedoeling om de schandalen in Engeland en Wales te vergelijken met de schandalen in Nederland. De schandalen zijn vaak qua aard en achtergrond zo verweven met de cultuur en de geschiedenis van elk van de landen dat een eenvoudige vergelijking van alleen de schandalen wetenschappelijk gezien onverantwoord zou zijn. Een dergelijke vergelijking zou naast een juridische en criminologische invalshoek, waartoe ik me beperk in deze studie, eveneens een analyse behoren te bevatten van culturele, politieke en maatschappelijke achtergronden. Evenmin is er sprake van een vergelijking van de politiekorpsen in Engeland en Walles met de regiokorpsen in Nederland. ${ }^{17}$ Immers in dat geval zou een staatsrechtelijk en historisch onderzoek van belang zijn geweest. Om andere redenen dan een wergelijking is het Nederlandse gedeelte derhalve opgenomen.

Het Nederlandse gedeelte is opgenomen als voorbeeld van een niet-onafhankelijk politieapparaat, ter onderscheiding van de onafhankelijke politiekorpsen in Engeland en. Wales. Dit komt tot uitdrukking in de bespreking van de Polutiewet 1993. Er wordt vervolgens ingegaan op de wijziging van de Nederlandse politieorganisatie die op een bestuurlijk/politieke wijze tot stand is gekomen; een wijze die haaks staat op de wijzigingen in de wetgeving van Engeland en Wales die allemaal tot stand zijn gekomen ter oplossing van een schandaal. De aandacht woor de achtergrond van de wetswijzigingen geschiedt in het kader van de theorie van Sherman. Verder illustreren de besproken schandalen bij de Nederlandse politie dat het controleren van een 'niet-onafhankelijk politieapparaat' toch soms tekortschiet. De voorbeelden in Nederland worden derhalve aangehaald om te tonen dat ondanks de aanwezigheid van formele controlemechanismen schandalen kunnen voorkomen. Het boek wordt afgesloten met enkele conclusies.

117. Niettemin wordt zo nu en dan wel kort verwezen naar de situatie in het andere land, maar dat geschiedt woornamelijk on de situatie beter uit te leggen. 


\section{Geschiedenis van de Engelse politie tot 1960}

\subsection{De 19de eeuw}

De geschiedenis van het huidige Britse politieapparaat begint in 1829 met de oprichting van een politiekorps voor de hoofdlstad Londen. Vóór 1829 bestond het 'politiekorps' uit onbetaalde parish constables en watchmen, die niet altijd even betrouwbaar en vaak dronken waren. ${ }^{118}$ Het hoofd van de constables was de high constable. De high constables waren over het algemeen van een hoge sociale stand en werden geselecteerd. Zij hielden voornamelijk toezicht op het innen van belastingen. ${ }^{119}$ De constables waren verantwoording verschuldigd aan de high constable. De constables van die dagen hadden verschillende werkzaamheden, waarvan het arresteren van verdachten er een was. Het voorkómen van misdaden behoorde niet tot hun werkzaamheden. De vervolging van verdachten geschiedde door de slachtoffers zelf. Het ambt constable was geen full-time bezigheid en meestal hadden de constables ook nog 'echt' (i.e. betaald) werk. ${ }^{120}$ Wel werd in London door de magistraat ${ }^{121}$ in Bow Street, Sir John Fielding, een soort van betaalde politie opgezet die bekend werd onder de namen van Bow Street Foot Patrol en Bow Street Runners. De Bow Street Rumners waren efficiënt en bekwaam in hun optreden, zowel in eigen land als in het buitenland. ${ }^{122}$

De Gordon riots, genoemd naar Lord George Gordon, van juni 1780, waarin Londen gedurende één week onderworpen was aan rellen, lieten blijken dat er iets aan het rechtssysteem niet functioneerde. Aanleiding van de rellen was een wetswoorstel '.. to remove certain Catholic disabilities. ${ }^{123}$

118. Goodhart, 1962, p. 157; Reiner, 1985, p. 11; Emsley plaatst hier een kantrekening bij: ook in de 18 de eeuw waren er watchnen die hun taak zeer serieus opvatten. De situatie was in die tijd niet zo slecht als vaak wordt afgeschilderd in de literatuur. Emsley, 1994, p. 158.

119. Emsley, 1987, p. 172.

120. Er waren ook constables die hun werk full-time vervulden. In dat gewal manien zij tegen betaling het werk over van de persoon die eigenlijk voor het werk geselecteerd was. Emsley, 1987, p. 172-173; Emsley, 1994, p. 157-158.

121. Deze magistraten, the trading justice, gaven tegen betaling juridisch advies. Niet alle magistraten deugden. Het kantoor van de Henry en John Fielding werd echter zeer positief beoordeeld. De broers Fielding kregen 'subsidie' van de regering en konden daardoor hun fees laag houden. Dit magistrate's kantoor in de Bow Street werd het voorbeeld voor de trading justice. Emsley, 1994. p. 158-159.

122. Meiville Lee, 1971 , p. 156-157; Critchley, 1979, p. 42-45; Pike, 1985, p. 3-5.

123. Ascoli, 1979, p. 46; Reiner, 1985, p. 12; zie ook Melville Lee, 1971 , p. 164 168. 
Er waren namelijk in de wet aan katholieken beperkingen opgelegd die tamelijk ver gingen. Een van die beperkingen was dat rooms-katholieken niet in het leger mochten. Toen in 1778 de regering dringend soldaten nodig had voor de militaire operaties in Amerika, werd overwogen deze beperkingen op te heffen door middel van de Catholic Relief: Act. ${ }^{124}$ Op 2 juni 1780 wilde Lord George Gordon een petitie aanbieden aan het House of Commons, warin hijzelf zitting had, teneinde de wet tegen te houden. Duizenden protestanten volgden hem onderweg naar het House. Deze demonstratie was, aanvankelijk, anti-katholiek van karakter en liep behoorlijk uit de hand. De watchmen waren niet in staat in die week de orde te handhaven. Het leger maakte op verzoek van de koning na deze week binnen drie dagen een eind aan de rellen. ${ }^{125}$

Aanvankelijk wilde men overgaan tot een vrijwillige burgerwacht en tot strengere strafbepalingen, maar daarnaast waren meningen te horen waarin gevraagd werd om een controleerbaar politie-apparaat. In het parlement werd in 1785 een poging ondernomen door de regering van William Pitt om een betaald politiekorps op te richten onder de leiding van een raad van toezicht. De Bill omvatte de oprichting van een politiekorps voor geheel Londen, inclusief de City. Dit laatste kon niet door de beugel volgens het parlement. Het zou een aantasting betekenen van de waardigheid van de City en een inbreuk zijn op het recht van zelfbestuur van de City. Dit voorstel werd om die reden door Pitt ingetrokken. ${ }^{126}$ Het woord "politie" had bovendien een slechte betekenis in het Engeland van die dagen. De term was afkomstig uit Frankrijk, en voor veel mensen was dit feit al voldoende

124. Hibbert, 1958, p. 15-33.

125. Het leger was verantwoordelijk voor meer dan 200 doden en bijna 250 gewonden. Daarbij kwamen nog tientalten mensen die ter dood werden veroordeeld. Lord George Gordon, als aanstichter, werd vanwege zijn 'insanity' niet vervolgd. In zijn King Mob, noemt Christopher Hibbert een dodental van 850 , 1958, p. 131. Melville Lee, 1971, p. 168; Critchley, 1979, p. 35; Ascoli, 1979, p. 47; Hibbert, 1958 , p. 90-93.

126. In dit woorstel zou Londen in negen politiedistricten worden werdeeld, warin in elk district cen drietal magistraten en 25 constables aangesteld zouden worden. Critchley, 1979, p. 36; Emsley, 1987, p. 176; Emsley, 1994, p. 159; Ascoli, 1979 , p. 49-50.

In 1792 echter werd de Middlesex Justices Act aangenomen. Op basis van deze wet werden in Londen zeven 'politie'-kantoren opgericht. De City of London wend buiten beschouwing gelaten. In elk van die kantoren hadden drje magistraten zitting en waren verder zes constables werkzaam. Onder leiding van Patrick Colquhoun, een magistraat, werd in 1798 een privé-politiekorps opgericht die de Dockyards van de Thames moesten beschermen. Emsley, 1994, p. 
om het idee van een politiekorps te verwerpen. ${ }^{127}$ De Franse gendarmerie werd vereenzelvigd met spionnen en verklikkers, en niet met ordehandhavers. Bovendien was men bevreesd dat op deze wijze het absolutisme via een politieke coup met gewapende eenheden, zoals op het continent voorkwam $^{128}$, binnengehaald zou worden. De Britten waren derhalve bang dat invering van een politiesysteem het einde zou betekenen wan de vrijheden van de burgers en onderdrukking en terreur zou teweegbrengen. ${ }^{129}$ Maar daarnaast was men bang dat de centrale overheid de rechten van de kleinere, lokale overheden zou inperken door de politie onder centraal gezag te plaatsen. ${ }^{130}$ Ook nog in $1812,1816,1817,1818$ en 1822 rapporteerden commissies negatief over de oprichting van een politiekorps naar continentaal model, aangezien dit "... would make every servant of every house a spy on the actions of his master..." ${ }^{131}$ en dus de vrijheid van het individu in gevaar zou brengen. ${ }^{132}$ Home Secretary ${ }^{133}$ Robert Peel stelde op 28 februari 1828 opnieuw een select committee in die o.a. na zou moeten gaan hoe het gesteld was met de politie van de hoofdstad ${ }^{134}$ Deze commissie kwam tot de conclusie dat de bestaande politie in veel opzichten gefaald had en dat dit ook herhaalde keren door commissies geconstateerd was. Zij adviseerde de oprichting van een ambt van politie (Office of Police) onder de leiding van de Home Secretary. ${ }^{135}$ Daarbij stelde de commissie het voordeel van het belang van het preventieve karakter van het politiewerk voor een ieder

127. '.. there was concern that a centralized police was something peculiarly foreign - worst of all, French - and that it would be a threat to liberty; ...' Emsley, 1994, p. 160; zie ook Emsley, 1.987, p. 172.

128. Franse revolutie.

129. Critchley, 1979. p. 35.

130. Emsley, 1994, p. 160.

131. Critchley, 1979. p. 47.

132. Onder Napoleon was de Franse politie nog meer dan eerst autoritair. Toen de eerste politieagenten in Londen verschenen werden ze 'general spies' genoend. Zie Fijnaut, 1979, p. 585; Critchley, 1979, p. 35. 47; Emsley, 1987, p. 177; Ascoli, 1979, p. 57.

133. Vergelijkbaar met de Nederlandse minister van Binnenlandse Zaken.

134. Op dat moment waren in Londen 300 constables van Bow Street, 80 agenten van de Thames River Police, 24 magistraten en hun constables en nog tal van kleinere parochiale korpsen werkzaam. Critchley, 1979, p. 48; Ascoli, 1979 , p. 74: Emsley, 1994, p. 159.

135. In die tijd was de industriële revolutie in volle gang. Dat betekende het groeien van de steden en een toename van het aantal arbeiders. Er ontstond bij de overheid een behoefte aan het beschermen van het eigendom van de hogere klassen en het beheersen van de arbeiders in de steden, die nog vak dronken en voch. ten. Vandaar o.a. de ommezwaai naar bet toestaan van een politïe. 
boven mogelijke inbreuken op de vrijheid van de individuele burgers, ${ }^{136}$ Peel diende in april 1829 een wetsontwerp in, dat veelal steunde op de aanbevelingen van de select committee. Op 19 juni 1829 werd de oprichting van een Metropolitan Police voor de stad Londen uiteindelijk een feit. ${ }^{137}$ Deze New Police stond onder de leiding van twee magistraten die rechtstreeks onder de minister stonden. ${ }^{138}$ De nadruk lag in die tijd op de voorkóning van misdaden. ${ }^{139} \mathrm{De}$ nieuwe agenten waren verplicht de bevelen van de magistraten op te volgen, op straffe van gevangenisstraf of ontslag. ${ }^{40}$

In de jaren daarna zou de politie ook in de rest van het land zijn opwachting moeten maken. Maar het zou nog enkele jaren duren voordat alle warch committees $^{141}$ politiekorpsen in het leven geroepen hadden. ${ }^{142}$ Het was in de wet onduidelijk geregeld wie de baas over de rural-politie ${ }^{14.3}$ zou worden. De politie moest de bevelen van de magistraten opvolgen, maar deze stonden niet onder de leiding van de Home Secretary, en werden bovendien niet geacht om daadwerkelijk leiding te geven aan de korpsen. De wet heeft ook aan de watch committee niet expliciet de bevoegdheid gegeven om de politie te bevelen, al was de watch committee wel verplicht elk kwartaal een rapport te sturen naar het Home Office $e^{144}$. Omdat de watch committee daarnaast wel de bevoegdheid had agenten te benoemen en te ontslaan, werd er lange tijd van uitgegaan dat er een soort master-servantrelatie bestond tussen watch committee en politie. ${ }^{145}$ Pas bij de inwerkingtreding van de Police Act 1964 zou deze situatie verhelderd worden. ${ }^{146}$ Vanaf het begin derhalve kan gezegd worden dat de politie buiten de hoofd-

136. In de commissie zat een aanhanger, Chadwick, van het Utilitarisme. Chadwick was onder invloed gekomen van Jeremy Bentham, die de oprichting voorstond van een centraal georganiseerd politiekorps onder leiding van de regering. Ook Peel was beînvloed door het Utilitarisme van Bentham. Critchley, 1979, p. 46; Pike, 1985, p. $9,41-42$; Het preventieve karakter van het werk van de politie werd opgenomen in de New Police Instructions. Emslley, 1987, p. 187.

137. Ascoli, 1979, p. 76-77.

138. Dit waren Colonel Charles Rowan en Richard Mayne, een jurist. Emsley, 1987, p. 180; Ascoli, 1979, p. 80; Pike, 1985, p. 10-11.

139. Benyon, 1984, p. 100.

140. Goodhart. 1962, p. 158.

141. Dit was een soort politiecommissie, onderdeel van de gemeenteraad.

142. In 1853 had een aantal van 13 gemeenten nog geen politiekorps gevormd. Zie Pike, 1985, p. 13-14.

143. Plaatselijke of districtspolitie.

144. Vergelijkbaar met het Nederlandse ministerie van Binnenlandse Zaken.

145. Zie ook Emsley, 1987, p. 182.

146. Critchley, 1979 , p. 66-67. 
stad onder geen enkele controle van het parlement stond en onafhankelijk van centraal politieke controle was. In 1856 - de inwerkingtreding van de County and Borough Police Act - veranderde deze positie enigszins thet de benoeming van drie inspecteurs van het Home Office, die als opdracht meekregen na te gaan of de korpsen buiten Londen voldoende efficientit functioneerden teneinde in aammerking te komen voor een toelage ter hoogte van een kwart van de uitgaven. ${ }^{147}$ Later werd deze toelage verhoogd tot ongeveer $50 \%{ }^{148}$ De onafhankelijkheid van de politie zou eveneens voor een deel beperkt worden door de Politiewet van 1919, zoals we hieronder zullen zien.

\subsection{De eeuwwisseling}

In het midden van de negentiende eeuw begon de politie voor de watch committees toch een dure aangelegenheid te worden. Het centraal gezag werd als gevolg daarvan ingeschakeld. Overeengekomen werd dat de overheid een jaarlijkse bijdrage zou leveren van $25 \%$. Dit bedrag werd in 1874 verhoogd tot $50 \%$. ${ }^{14 \%}$ Het lokaal bestuur zou zorg moeten dragen woor het resterende bedrag. De overheid eiste het recht on controle over de korpsen uit te oefenen, hetgeen zou geschieden door inspecteurs. Deze inspecteurs zouden alle korpsen in Groot-Brittannië jaarlijks aan een onderzoek onderwerpen on te zien of er wel efficiënt met het geld van de overheid omgesprongen werd. De inspecteurs werden derhalve ingesteld om de efficièntie van de korpsen te verhogen. De inspecteurs kwamen in de praktijk echter al gauw tot de conclusie dat de enige mogelijkheid om een hoge efliciëntie te bereiken, het versterken van het politiekorps met manschappen was. "The smaller the police-population ratio, the more efficient the force." 150 In 1890 ontvingen alle 183 politie-korpsen een jaarlijkse financiële bijdrage en stonden bovendien alle korpsen onder toezicht van de inspecteurs van het Home Office. De daadwerkelijke controle van de minister was echter minimaal.

Vór de Eerste Wereldoorlog, had het ministerie (Home Office) weinig oog gehad woor de politie. Van echt contact was geen sprake. In het geval dat er strubbelingen wóórkwamen, adviseerde het ministerie het aantal manschappen te vermeerderen.

147. Goodhart, 1979, p. 159; Pike, 1985, p. 14-15.

148. Dit gebeurde in 1874. Pike, 1985, p. 15.

149. Dit werd voornamelijk gedaan om het Home Office meer controle te geven. Emsley, 1994, p. 163.

150. Brogden, 1982, p. 99. 
Rond $1918 \mathrm{trad}$ in de houding van de regering verandering op. ${ }^{151}$ Tot 1918 hadden de watch committees de controle over het antal agenten in hun gebied gehad. Vanaf die tijd echter, stonden zowel de efficiëntie als het aantal manschappen onder de leiding van het Home Office. Dit had de overheid als nieuwe voorwarde voor de financiële toelage bedongen.

\subsection{De periode rond en na de Eerste Wereldoorlog}

De periode rond de Eerste Wereldoorlog wordt gekenmerkt door een onvrede binnen de politieorganisatie. Algehele ontevredenheid bestond over de slechte betaling van het werk. De hoogte van het loon was al meer dan 80 jaar gelijk aan dat van een arbeider, waarbij geen rekening werd gehouden met inflatie. ${ }^{152}$ Het is derhalve niet vreemd dat agenten besloten voor hun rechten op te komen. Al vór de aanvang van de Eerste Wereldoorlog was een ex-lid van de Metropolitan Police overgegaan tot de oprichting van een politievakbond, de Metropolitan Police Union ${ }^{153}$. De bond was niet toegestaan. In december 1913 namelijk maakte het hoofd van de politie in Londen, Sir Edward Henry, bekend dat het agenten verboden was om lid te worden van deze organisatie en dat '... any man serving who violates these Orders or incites others to violate them renders himself liable to disciplinary proceedings which may result in his dismissal from the Force. ${ }^{154}$ Desondanks had de Union tijdens de Eerste Wereldoorlog veel leden gekregen onder politieagenten. In het parlement was er vooral uit de socialistische hoek steun voor de vakbond. ${ }^{155}$

Tegen het einde van de oorlog verslechterde de situatie. De politieagenten werden zo slecht betaald, dat ze leefden op de grens van de armoede; bovendien hadden ze er genoeg van dat ze niet in beraadslagingen betrokken werden, the right to confer. De Police Union probeerde natuurlijk op deze gebieden één en ander te regelen. Sir Edward Henry maakte zich zorgen over de toenemende ontevredenheid onder de agenten en sprak de toenmalige Home Secretary Sir George Cave hierover aan. Deze geloofde niet dat

151. Brogden, 1982, p. 101 .

152. Ascoli, 1979, p. 196.

153. Dit gebeurde in 1913 door de jonge inspecteur John Syme, die in 1910 uit de dienst ontslagen was. Later werd de Metropolitan Police Union omgedoopt tot National Union of Police and Prison Officers (NUPPO). Zie hierover Morgan, 1987, p. 68; Hetgeen de Union met name wilde was politieke controle over het politieapparaat. Ascoli, 1979, p. 197-198.

154. Ascoli, 1979, p. 193.

155. Drie partementsleden waren op een gegeven moment zelfs lid van de Union. Ascoli, 1979, p. 196. 
de agenten de veiligheid van het land in gevaar zouden brengen en ondernam weinig actie. ${ }^{156}$

In Londen werd op 25 augustus 1918 een politieagent, Thomas Theil ontslagen vanwege zijn activiteiten voor de vakbond. ${ }^{157}$ De Police Union kwam hiertegen in opstand en stelde de Commissioner Henry een ultimatum, terwijl bekend was dat hij op vakantie in Ierland was. ${ }^{158}$ Hun eisen waren de volgende: (1) het ontslag van Theil ongedaan maken, (2) een salarisverhoging en (3) de erkenning van de Police Union. De vervanger van de Commissioner, Wodehouse, ging niet op deze eisen in. Vandaar dat op 30 augustus 1918 een totaal van 12.000 politieagenten van de Metropolitan Police $^{159}$ (nagenoeg het gehele korps) in staking ging. Het land verkeerde echter nog in oorlog. Dat was de reden dat de regering terugkrabbelde; tijdens de oorlog was de regering teveel op de politie aangewezen. De regering kon zich derhalve geen stakende agenten veroorloven. Het ontslag werd ongedaan gemaakt en de regering beloofde loonsverhoging en erkenning van de Police Union. ${ }^{160}$ De salarisverhoging werd verwezenlijkt, maar de Police Union werd niet erkend. Dat vond men in oorlogstijd te gevaarlijk. De regering ontsloeg het hoofd van de Metropolitan Police (Sir Edward Henry), en benoemde in diens plaats een militair als hoofd van de Londense politie (General Macready). ${ }^{161}$ De sfeer in het politiekorps verbeterde als gevolg hiervan nauwelijks. ${ }^{162}$

De onvrede onder de politieagenten bleef bestaan. In maart 1919 werd de Desborough Committee ${ }^{163}$ ingesteld naar aanleiding van de eerste politiestaking. ${ }^{164}$ Deze commissie had als taak onderzoek in te stellen naar de arbeidsomstandigheden van de politie: '... to consider and report whether any

156. Dit gebeurde in $\$ 917$. In 1918 riep Cave wel een vergadering bijeen om over de betaling van de agenten te spreken, mar toen was het inmiddels te laat. Ascoli, 1979 , p. 197.

157. Morgan, 1987 , p. 69 spreekt wan Theil; Ascoli, 1979, p. 198-199 noemt de agent Thiel.

158. Ascoli, 1979, p. 198.

159. Zie over de oprichting van de Metropolitan Police het hoofdstuk over de Police Act 1964.

160. Fijnaut, 1979, p. 206-207; Ascoli, 1979, p. 199.

161. Ascoli. 1979, p. 199-200.

162. Fijnaut, 1979 p. 207.

163. De commissie bestond uit vooraanstaande mensen. Desborough zelf was de voorzitter. Daamaast namen deel Lord Gorell (War Office), F.D. Blake (een liberale baron), Henry Craik (ambtenaar), James Remnant (een toekomstige Tory peer) en twee Labour parlementsleden, James Sexton en James O'Grady.

164. Emsley. 1994, p. 165. 
and what changes should be made in the method of recruiting for, the conditions of service of, and the rates of pay. pensions, and allowances of the police forces of England, Wales and Scotland." de commissie al een rapport klaar. Uit het rapport bieek dat de commissie tegenstander was van een politievakbond als de Police Union. Zij was bang dat de neutraliteit van de politie in het gedrang zou komen bij het bedwingen van oproeren. Bovendien zouden grotere vakbonden (met 'communistische' elementen) de politie als vakbond kunnen vragen om uit solidariteit niet op te treden bij bepaalde stakingsacties. De commissie stelde daarvoor in de plaats de oprichting voor van een vertegenwoordigende politieorganisatie (Police Federation). ${ }^{165}$ Op grond van de aanbevelingen van de Desborough commissie werd een ontwerp van wet ingediend in het parlement op 8 juli 1919. In dit wetsontwerp werd het agenten verboden toe te treden tot een vakbond. Dit was voor de Police Union weer aanleiding om een staking af te kondigen tegen het voorstel in de wet inzake een verbod van een politievakvereniging. De staking had derhalve voornamelijk het voortbestaan en de erkenning van de politiebond tot doel. ${ }^{457}$ De staking vond plaats op 31 juli 1919. De regering werd deze keer niet gehinderd door de oorlog of door de grote omvang van de staking. Slechts een, in verhouding, gering aantal politieagenten nam aan de staking deel. Alle stakende politieagenten, 2.365 in totaal, werden ontslagen en nooit meer in dienst genomen. ${ }^{168}$ De National Union of Police and Prison Officers (NUPPO), de latere naam voor de Police Union, viel qua organisatie en financiën binnen enkele dagen uiteen. Volgens Fijnaut was, na deze actie van overheidswege - dankzij Macready -, de loyaliteit van de politie weer hersteld en de regering had weer vertrouwen in de politie gekregen. ${ }^{169}$

De Police Act van 1919 was gebaseerd op de voornaamste aanbevelingen van Desborough. De wet introduceerde een centraal geleid en uniform systeem van lokale politiekorpsen. ${ }^{170}$ Het Home Office kreeg de bevoegdheid algemene richtlijnen te maken op het gebied van de sterkte, het materieel, de huisvesting, de dienstorganisatie, het loon en andere vergoedingen, de kleding, enz. De toelage (grant) van de overheid nam hierdoor toe.

165. Ascoli, 1979, p. 201.

166. Zie ook Emsley, 1991, p. 15 1-152.

167. Crichley, 1979, p. 184-188.

168. Critchley, 1979, p. 189; Morgan, 1987, p. 83

169. Fijnaut, 1979, p. 208; Ascoli, 1979, p. 205.

170. Critchley, 1979, p. 194.

Enkelle andere aanbevelingen van de commissie waren de volgende: (a) de oprichting van cen politie-departement op het Home Office; (b) het aantal inspecteurs tot drie te brengen; en (c) de ontwikkeling van samenwerkingswerbanden tussen politiekorpsen. 
Voortaan vergoedde de overheid de helft van alle kosten van de politie, en niet slechts de helft van het salaris en de kleding van de agenten, zoals voordien het geval was. Dit had verder tot gevolg dat het toezicht op de besteding van de toelage groter werd. Via de geldkraan versterkte dus de informele controle.

De Police Act 1919 verbood, zoals hierboven al aangegeven, de Police Union, maar stelde in plaats daarvan de oprichting van een Police Council en een Police Federation voor ${ }^{171}$. De Police Council was een orgaan waarin de politie en de centrale en lokale overheid vertegenwoordigd waren. Als politieraad werd zij geadviseerd en betrokken bij het overleg over politieaangelegenheden door de minister van het Home Office. De Police Federation was duidelijk bedoeld als alternatief voor de Police Union. ${ }^{172}$ Het werd agenten yerboden zich aan te sluiten bij vakbonden buiten de politiewereld. Het recht tot staking werd de agenten ontzegd. ${ }^{173}$ De Police Federation zou de agenten in staat moeten stellen 'to consider and bring to the notice of police authorities and the Secretary of State, all matters affecting their welfare and efficiency other than questions of discipline and promotion affecting individuals. ${ }^{174}$ Met de oprichting van de Police Federation werd het al zo lang gewenste right to confer dus eindelijk werkelijkheid. ${ }^{175}$

De stakingen van de jaren 1918-1919 hadden de crisis over de controle en de organisatie van de lokale korpsen versneld. Tijdens de oorlog had het Home Office als noodmaatregel een coördinerende rol. Hierdoor verdween het lokale karakter van de politie voor een deel. ${ }^{176}$ Door middel van de instelling van een nieuw Police Department werd in 1919 deze rol met bijbehorende verantwoordelijkheden geformaliseerd. Door de politiestakingen en de opkomst van de arbeidsorganisatie werd de interventie van de centrale overheid versneld. Volgens Brogden was desalniettemin het ministe-

171. Zie voor de wettelijke bepalingen Police Act 1964, sec. 44

172. Zie ook Reiner, in Holdaway, 1979 , p. 150 e.v.

173. Fijnaut, 1979, p. 208.

174. Critchley, 1979, p. 194.

175. Critchley, 1979, p. 192; Ascoli, 1979, p. 202.

176. Tijdens de Eerste Wereldoorlog werkten de politiekorpsen nauw samen met de Secret Service, teneinde op het spoor te komen van spionnen. Na de Russische Revolutie van 1917 kwam daar nog de angst voor bolsjewistische spionnen bij. Enkele hoofdcommissarissen "vereenzelfden" als gevolg daarvan het bolsjewisme met de Labour Party. Dit leidde tot conflicten met de lokale overheden. Het Home Office steunde echter de hoofdcommissarissen bij het oplossen van industriële onlusten en rellen. Emsley, 1994, p. 164-165. 
rie onmiddellijk na de oorlog terughoudend in het interveniëren. ${ }^{17}$ Tengevolge van de algemene economische en politieke onrust in de twintiger en dertiger jaren en de opkomst van een Engelse fascistische beweging werd de invloed van de overheid op het politieapparaat uitdrukkelijker. ${ }^{178}$ Het ministerie ging zich bezighouden met het ontwikkelen van politiebeleid en met de centrale coördinatie. De ontwikkeling in de uitvoerende macht van het ministerie had meer lokale autonomie voor de hoofdcommissarissen tot gevolg.

\subsection{De Tweede Wereldoorlog}

Gedurende de eerste maanden van de Tweede Wereldoorlog werd het aantal manschappen van de politie aanzienlijk vergroot, mede dankzij de vrijwillige reservepolitie. Het gezag over de politie werd in de periode 1942-1943 ook gecentraliseerd. ${ }^{179}$ Dit werd voornamelijk gedaan teneinde te bereiken dat het beleid op het gebied van de bescherming en nationale veiligheid efficiënt en consistent zou zijn. De centralisatie hield ten eerste in dat de minister van het Home Office, mr. Herbert Morrison, de mogelijkheid had instructies te geven aan de politiekorpsen in het kader van de algemene veiligheid en de ordehandhaving. Fijnaut merkt hierbij op dat dit de eerste keer in de geschiedenis van de Engelse politie was dat de minister een dergelijke zeggenschap over de politie kreeg. ${ }^{180}$ De centralisatie had ook tot gevolg dat de politiekorpsen geregionaliseerd werden. Het land werd in 11 regio's verdeeld en kleine politiekorpsen werden samengevoegd. ${ }^{181}$ Het land had behoefte aan grotere politie-eenheden. Het zou de efficiëntie van het politieoptreden ten goede komen. Aanvankelijk bestond tegen het samenvoegen wan korpsen in het parlement veel bezwaar en de minister moest beloven om niet op deze wijze over te willen gaan tot nationalisering. Daarnaast moest hij de belofte doen de samenvoegingsregelingen na de oorlog in te trekken. ${ }^{182}$

177. De Emergency Powers ACr 1920 vormde daarop een uitzondering. Op grond van deze wet kon de Howe Secretary een hoofdcommissaris bevelen $10 \%$ van zijn manschappen butten zijn jurisdictie in te zetten. Emsley, 1994, p. 164.

178. Brogden, 1982, p. 102.

179. Bij het uitbreken wan de oorlog in 1939 werd dit niet direct noodzakelijk geacht. Een mogelijke irvasie was geen voldoende reden om korpsen samen te voegen. Critchley, 1979, p. 241.

180. Fijnaut, 1979 , p. 302.

181. Dit gebeurde onder de Defence (Amalgamation of Police Forces, Regulations, 1942.

182. Critchley, 1979, p. 241 . 


\subsection{De periode na de oorlog}

Na de oorlog kwam de vraag aan de orde of de hervormingen die gedurende de oorlog waren ingevoerd binnen het politie-apparaat, voortgezet moesten worden. ${ }^{183}$ Binnen de kring van politiecommissies was veel verzet tegen deze hervormingen, die hun macht over de plaatselijke korpsen inperkten. De minister had vlak na de oorlog voorgesteld de in de oorlog ontstane samenvoegingen van korpsen in stand te houden. Over dit voorstel had hij overleg gevoerd met de hoofdcommissarissen. Zij waren van mening dat de samenvoegingen een verbetering inhielden van de efficièntie van het politieoptreden. De minister wilde met de fuseringen verder gaan, in die zin dat hij meer kleinere politiekorpsen wilde laten overgaan in grotere ${ }^{184}$. Home Secretary Mr. Chuter Ede diende na de verkiezingen van 1945 een ontwerp van wet in waarin hij o.a. de afschaffing van alle non-county borough korp$\operatorname{sen}^{185}$ voorstelde. Dit voorstel ging het parlement zonder een amendement te ver. In de nieuwe wetgeving ${ }^{186}$ werd derhalve bepaald dat gemeenten of counties met een inwonersaantal boven de 100.000 niet verplicht konden worden tot een fusie. ${ }^{187}$

\subsection{Afsluiting}

In de geschiedenis van de politie in Engeland en Wales is een lijn te zien. Terwijl de politieorganisatie en het parlement probeerden de onafhankelijkheid van de politie in stand te houden, kreeg de regering toch langzaam maar zeker meer zeggenschap over de politie. Na verloop van tijd droegen agenten hetzelfde uniform, werden gelijk betaald, ontvingen dezelfde opleiding en werden op dezelfde selectiegronden aangenomen. Dit proces verliep heel geleidelijk en niet opvallend. De Britten zijn bevreesd voor een nationale politie naar continentaal model. De politie moest stammen uit de maatschappij en optreden voor de maatschappij. Te veel macht was taboe. 'Our national police has always been of the people and for the people. "18. Ook tegenwoordig doen deze ideeën over de politie nog opgeld. In het volgende hoofdstuk zal dat blijken.

183. Fijnaut, 1979, p. 304.

184. Critchley, 1979 , p. $242-243$

185. Dit waren politiekorpsen in kleine gemeenten. Sommige van die korpsen hadden minder dan 50 mensen in dienst. Critchley, 1979, p. 240-241.

186. Police Act 1946, bekrachtigd op 15 april 1946.

187. Fijnaut, 1979, p. 305

De samenwoegingen werden na 1960 voortgezet onder o.a. de Police Act 1964. De samenvoegingen wan direct na de Tweede Wereldoorlog hadden het total van de korpsen gebracht op 125.

188. Melville Lee, 1971, p. 61. 


\section{Het politiekorps in zijn huidige vorm}

\subsection{Inteilding}

In dit hoofdstuk wordt de structuur van het politieapparaat besproken. Dit is noodzakelijk voor een goed begrip van de politie en haar verhouding met overheden. Daarbij komen tevens kort andere politiediensten dan het gewone 'bobby'-korps aan de orde. De vraag wie zeggenschap en macht over het politieapparaat heeft wordt behandeld aan de hand van jurisprudentie.

De organisatie van de politiekorpsen in Engeland en Wales wordt hier beschreven in de huidige situatie. Al bestaat het politieapparat formeel uit 43 afzonderlijke korpsen, de organisatie is voor alle korpsen gelijk. Zoals in het voorgaande hoofdstuk beschreven is, ligt de basis van de organisatie bij de oprichting van de Londense politie in 1829 onder leiding van Peel. Andere korpsen zijn naar dit model gevormd. Een goed historisch overzicht geeft Critchley in zijn boek. ${ }^{189}$

\subsection{Structuur en functies}

Tot voor kort zag de structuur er als volgt uit. ${ }^{190}$ Aan de top van de hiërarchie van een politiekorps staat de hoofdcommissaris. Hieronder staan twee of meer assistants chief constables. Eén houdt zich bezig met de administratie van het korps, de ander is hoofd van Operations. De volgende in lijn is de divisional commander, in de rang van chief superintendent. De hiërarchie breidt zich verder uit naar de sub-divisional commander, die zowel de rang kan hebben van superintendent of chief inspector. Er zijn recent enkele rangen verdwenen.

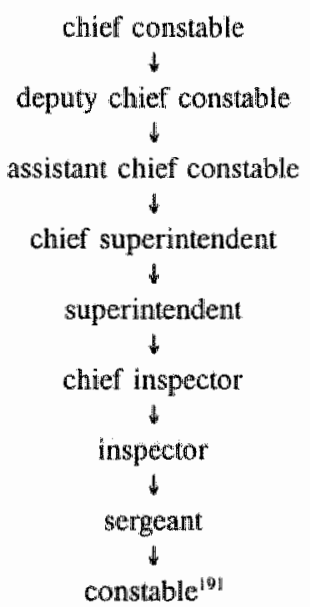

189. Critchley; 1979 .

190. Het rangensysteem heeft recent een wijziging ondergaan.

191. De promotie van constable naar sergeant neent minimaal twee jaar in beslag. De zelfde termijn geldt voor de promotie van sergeant naar inspector. Aan de promoties zijn examens verbonden " die door de agenten gehaald moeten worden. Vanaf de rang van inspector gelden geen termijnen meer. Er dienen ook geen examens meer afgelegd te worden. Wel zijn de agenten hoger in rang 'verplicht' cursussen te volgen. 
Vanaf de inspectors in de pyramide is er niet alleen een geografische verdeling (areas), maar ook een verdeling naar tijd (shifts). ${ }^{192}$

\subsection{Interne structuur van de Metropolitan Police}

De hierarchische indeling van de Londense politie verschilt enigszins in voornamelijk de hogere rangen. Bij de Metropolitan Police zijn de rangen van chief constable en assistant chief constable niet opgenomen. In plaats daarvan zijn er in dat korps de rangen van commissioner, deputy commissionér, assistant commissioner, deputy assistant commissioner en commander.

Het hoofdbureau van de Metropolitan Police is New Scotland Yard. De commissioner is de baas. ${ }^{193}$ De deputy commissioner die direct onder hem staat, geeft leiding aan het korps als de commissioner afwezig is. ${ }^{194}$ Daarnaast heeft de commissioner steun van een viertal assistant commissioners. leder van hen is hoofd van één van de vier hoofddepartementen van de Metropolitan Police: politieoperaties (A), verkeer en technische ondersteuning $(B)$, crimineel onderzoek $(C)$, personeel en opleiding $(D){ }^{195}$

In 1979 werd Londen verdeeld in vier grote gebieden. ${ }^{196}$ Deze gebieden, met aan het hoofd een deputy assistant commissioner, waren verder onderverdeeld in zes districten. Dit met het oog om efficiënter te werk te gaan.

192. Een shiff houdt in dat het werk verdeeld is naar drie tijdseenheden. Bijvoorbeeld van 8.00 uur tot 16.00 uur, van 16.00 uur tot 24.00 uur en van 24.00 uur tot 8.00 uur. Bunyard, 1978, p. 65 .

193. Ascoli, 1979, p. 350 .

194. De deputy conmissioner houdt verder toezicht op de discipline binnen en inspectie van het korps. Bij hem komen de klachten over het politieoptreden terecht. Hei directoraat management services, public relations en de hoofdbuteaus vallen eveneens onder zijn leiding.

195. Stead, 1985, p. 110.

Over de verdeling van taken binnen de vier hoofdafdelingen van de Metropolitan Police zall ik hier in het kort nader informatie geven. Onder afdeling $A$ (police operations) vallen 0. a. patrouilleren, misdaadpreventie, bescherming van leden van her Koninklijk Huis en van ambassades, jeugdcriminaliteit, de bereden politie en de politiehonden. De assistent hoofdcommissaris van afdeling $B$ (Ver* keer) is woornamelijk verantwoordelijk voor de verkeerssituatie in Londen en de taxivergunningen. Onder afdeling $C$ vallen alle afdelingen die om éen of andere reden met misdaad in verband staan. Detectives, laboratoria, CID, fraudebrigade, anti-terreur- en drugsbrigades, gestolen motorrijtuigen en de Special Branch (een anti-terroristische afdeling) kunnen genoemd worden. Afdeling $D$ tenslotte omvat personeelszaken, opleiding en werving van recruten.

196. Afgezien van de City of London. 
In 1987 werd het korps echter opgedeeld in acht gebieden (areas). Deze gebieden zijn verder onderverdeeld in een totaal wan 75 divisies. ${ }^{197}$ Aan de leiding van een gebied staat een deputy assistant commissioner, geassisteerd door een commander. ${ }^{198}$

\subsection{Overige politiediensten}

Naast de reguliere politie, zijn er nog de bijzondere politieagenten. ${ }^{199}$ De bijzondere agenten (in het Engels aangeduid met de term special constables) zijn vrijwilligers onder de bevolking die de reguliere politie te hulp komen bij noodtoestanden of speciale gebeurtenissen. Ook deze bijzondere agenten vallen onder de leiding van de hoofdcommissaris. Een bijzondere politieagent is alleen bevoegd in het gebied waarvoor hij is aangesteld. Een verdergaande bevoegdheid geldt echter ook voor hem indien zijn aanwezigheid wanneer een ander korps om wersterkingen vraagt - ergens anders in het land gewenst is. Oud-politieagenten, die bereid zijn bij te springen in geval van nood, vormen gezamenlijk de First Police Reserve.

Verder bestaan er nog de specialistische politiediensten. Deze agenten hebben een beperkte jurisdictie. Gewapende overheidsdiensten beschikken allemaal over politie. Genoend kunnen worden de Ministry of Defence Police, de Royal Navy Regulating Branch, de Royal Marines Police, het korps van de Military Police van het leger en de Royal Air Force Police.

De grootste specialistische politiedienst is de British Transpont Police. Dit korps heeft meer dan 2000 mensen in dienst. Aan het hoofd van dit korps

197. Een divisie van de Metropolitan Police wordt geleid door een chief superintendent, bij deze taak geholpen door een superintendent. Een divisie heeft terminste twee politiebureaus, waarvan één bekend staat onder de naam Divisional Station. Clayton, Tomlinson, 1987, p. 34. In 1993 bestond de Metropolitan Police uit meer dan 28.000 agenten. De totale grootte van de politiekorpsen in Engeland en Wales was in 1993 154.738. Benyon, Turnbull, Willis, Woodward en Beck, 1993, p. 104, 106.

198. Clayton, Tomlinson, 1987, p. 34; Stead, 1985, p. 109. De Metropolitan Police bestond uit 24 districten. Tot 1987 was elk district opgebouwd uit divisies en subdivisies. Deze districten waren ondergebracht in vier inspecties. Aan het hoofd van een inspectie stond een deputy assistant commissioner. Hij was verantwoordelijk voor de doelmatigheid van het politie-optreden in dat gebied. De districten stonden onder leiding van commanders. Deze districten konden weer verdeeld worden in afdelingen (divisions), waar een chief superintendent aan het hoofd stond, bijgestaan door eén of meer superintendents; Zie over de organisathe van de politie in Londen voor 1987: 'De Politie in Engeland', 1989, p. 323.

199. 'De politie in Engeland', 1989, p. 320 . 
staat een hoofdcommissaris. Dit korps is werkzaam op stations en in treinen, bij het openbaar vervoer in Londen, in havens en op vliegvelden met spoorwegverbinding. De taak wan dit korps komt grotendeels owereen met de taak van de politie in het algemeen: misdaad opsporen, orde handhaven en het assisteren van het publiek zijn hiervan voorbeelden. Daamaast zorgt deze dienst voor de bescherming wan mensen en goederen bij het treinverkeer. Het korps heeft een afzonderlijke Police Federation. ${ }^{200}$ Een bespreking van deze en de andere hierboven genoemde diensten blijven verder in dit verhaal achterwege.

\subsection{Bevoegdheden}

Een Engelse politieagent mag in heel Engeland en Wales optreden. Zijn bevoegdheden, die niet afgeleid of gedelegeerd zijn, winden hun basis in de Common Law. De Engelse agent is 'an officer of the law', hetgeen wil zeggen dat hij een dienaar is van de wet en dus niet in dienst is van de lokale overheid ${ }^{201}$ of de centrale owerheid. Hij heeft de plicht de wet te handhaven. ${ }^{202}$ Wel moet de agent de bevelen van zijn (directe) bazen opvolgen. ${ }^{203}$ De agenten zijn onderworpen aan disciplinaire bepalingen, opgenomen in Schedule I van de Police (Discipline) Regulations $1985^{204}$. Het is mogelijk dat bevelen van hogerhand in strijd zijn met de onafhankelijkheid van de individuele politieagent, maar in die gevallen hebben de disciplinaire bepalingen woorzien door rekening te houden met omstandigheden. ${ }^{205}$ Buiten het politiekorps is een agent onathankelijk in die zin dat hij geen verantwoording hoeft af te leggen aan het lokaal of centraal gezag. Het leidt geen twijfel dat agenten net als iedere andere burger wel verantwoordelijk zijn jegens de wet.

200. Stead, 1985, p. 134-136.

201. Dit is een politiecommissie. Een politiecommissie (police authority, artikel 3 Police ACt 1994) bestaat wit 17 leden; deels uit leden van de gemeenteraad (9), deels uit magistraten (3)en deels uit een vijftal leden gekozen uit een short-list van de minister. Her is hun taak te zorgen dat het politiekorps efficiënt functioneent. Schedule IB, section I van de Police ACt 1964.

202. Jefferson en Grimshaw, in Cowell, Jones en Young, 1982, p. 84.

203. Paragraf 3 van Schedule I van de Police (Discipline) Regulations 1985; Disobedience 10 orders:

Disobedience to orders, which offence is commitied where a member of a police force, withoul good and sufficient cause-

a. disobeys or neglects to carry out any lawful order, written or othenwise …

204. SI 1985. No. 518.

205. paragraat 3: good and sufficient cause. 
Elke politieagent in Engeland en Wales 'holds the office of constable, 206 . Zijn voornaamste taak is de vrede te bewaren. ${ }^{207}$ Daarnaast heeft hij als taken o.a. de bescherming van personen en goederen, de woorkoming van misdaad en de opsporing van misdadigers. ${ }^{208}$ De functie van constable behoort onpartijdig te zijn. Derhalve kan een agent bepaalde functies niet vervullen. Actief deelnemen aan een politieke partij is bijvoorbeeld uit den boze. Lidmaatschap van een vakbond is eveneens niet mogelijk, zoals we in het voorgaande hoofdstuk gezien hebben. Zakenbelangen kunnen ook onverenigbaar zijn met het ambt van constable. ${ }^{209}$

Tot 1986 kon de politie zonder tussenkomst van de Crown Prosecution Service (CPS) verdachte personen vervolgen voor het begaan van strafbare feiten. ${ }^{210}$ De politie had voor het vervolgen van verdachten het alleenrecht. De politie onderzocht zaken en besloot of een persoon in staat van beschuldiging gesteld moest worden. Daarna bekeek de politie of er reden was tot (verdere) vervolging. Vanaf 1986 beslist de politie niet meer over verdere vervolging. Dat doet sinds 1986 de CPS. De politie bezit nog wel de bevoegdheid om bij een ontdekking van een strafbaar feit de zaak al dan niet zodanig te classificeren. De politie behoudt derhalve de mogelijkheid een zaak te seponeren of met een waarschuwing af te doen. ${ }^{211}$

\subsection{De politie en de lokale overheid}

$\mathrm{Al}$ is de politie formeel onafhankelijk, op lokaal niveau moet de hoofdcommissaris vaak overleg voeren met een plaatselijke politiecommissie. Daarbij kan een politiecommissie de politie om inlichtingen vragen of adviseren. Het is de vraag in hoeverre de politie deze bemoeienis van de lokale overheid op prijs stelt.

Het gemeentebestuur of de gemeenteraad (city council) in Engeland en Wales heeft geen directe inbreng in het beleidsvormingsproces of de uitrus-

206. Lewis y. Cottle, (1938) 2 K.B. 454.

207. to preserve the Queen's peace.

208. Card, 1979, p. 9.

Vroeger hoorde bij het rijtje van taken nog de beslissing om al dan niet tot vervolging van verdachten over te gaan, maar sedert de oprichting van de Crown Prosecution Service wordt die beslissing door een prosecutor genomen.

209. Card, 1979, p. 9.

210. Alleen de ernstige zaken werden door de Director of Public Prosecutions behandeld; zic verder. Zie ook Roording, 1996, p. 23-39.

211. De CPS kan de politie wel advies geven ower de vraag of tot een vervolging moet worden besloten. Zie verder. Tak, 1988, p. 35; Tak, Lensing, 1990, p. 67. 
ting van het politiekorps dat operationeel is in zijn gemeente. De gezaghebbende autoriteit op dit gebied is de police authority , de officiële benaming voor een politiecommissie. Deze commissie is voor tweedende deel samengesteld uit leden van de gemeenteraad, gekozen door en uit de raad, en woor eenderde deel uit magistraten, benoemd tijdens een driemaandelijkse zitting van magistraten uit het district waar de gemeente onder valt (quarter-sessionsi). ${ }^{212}$

De taak van de politiecommissies was als volgt in de Police Act 1964 omschreven: "... to secure the maintenance of an adequate and efficient police force for the area, and to exercise for that purpose the powers conferred on a police authority by this Act. ${ }^{213}$ De wet werd laatstelijk gewijzigd met de invoering van de Police and Magistrates' Count Act 1994. Tengevolge van deze wet luidt de nieuwe taakomschrijving aldus: "It shall be the duty of every police authority established under section 3 of this Act to secure the maintenance of an efficient and effective police force for its area.' De verantwoordelijkheid van de politiecommissie omvat in hoofdzaak de zorg voor een efficiënt politiekorps voor wat betreft de gebouwen, de voertuigen en de uitrusting van de politieagenten.

Een politiecommissie kan over bepaalde onderwerpen een hoofdcommissaris adviseren of om inlichtingen vragen. Onderscheid moet hierbij gemaakt worden tussen "beleidszaken" en "operationele" zaken. Van zuiver operationele zaken moet een politiecommissie zich afzijdig houden en mag derhalve een hoofdcommissaris daarover niet lastig vallen. Beslissingen zijn operationeel wanneer zij bijvoorbeeld instructies bevatten betreffende het inzetten van politieagenten of middelen om een bepaald doel op het terrein van de wetshandhaving te bereiken. 'Beleid' is een verzamelterm voor beslissingen die centraal gemaakt worden met betrekking tot het bestuur en de strategie van het korps of die te maken hebben met de algemene aanpak van specifieke (maatschappelijke) problemen. Over de inhoud van het algemene beleid kan een politiecommissie vragen stellen aan een hoofdcommissaris of advies geven. Een grens tussen de twee soorten beslissingen is echter heel moeilijk te trekken. Het geeft de commissaris de mogelijkheid beleidszaken het etiket van operationele zaken te geven indien hij in een specifiek geval liever geen inbreuk van de politiecommissie op zijn beleid duldt. ${ }^{214}$ Deze handelwijze geeft de hoofdcommissaris derhalve de vrijheid al dan niet te bepalen of zijn

212. Wade, $1988, p, 142$

213. Art. 4 Police Act 1964 .

214. Dit kan ook subtieler gebeuren, o, a. door het inpalmen van de politiecommissie. Chris Mullin geeft daar een leuk voorbeeld van in het interview in de bijlage. 
politiecommissie ingelicht zal worden over de gang van zaken in zijn district. $^{215}$

Leigh is van mening ${ }^{216}$ dat het gebrek aan macht van politiecommissies om hun hoofdcommissarissen te beinvloeden, de geest van de oorspronkelijke ethos van het politieoptreden in Groot-Brittannië weergeeft.

'... The relative weakness of the local police authorities ... reflects the fact that it was never intended that such authorities should seek to control the police in the exercise of their functions. The Police Act, by investing the Chief Constable with such responsibilities, responded to the very high value placed upon the principle that the Chief Constable should be free from the conventional process of democratic control and influence in relation to operational matters. ${ }^{217}$

De geschiedenis toont dit aan. De Metropolitan Police Act 1829 heeft geen voorzieningen getroffen voor het afleggen van verantwoordelijkheid door hoofdcommissarissen van politie. De Police Act 1964 heeft eveneens dit beginsel van onafhankelijkheid gesteund. Een uitbreiding van het democratisch principe, dat plaats zou vinden als een politiecommissie invloed zou kunnen uitoefenen op het politiebeleid, zou een aantasting betekenen op het handelen van hoofdcommissarissen.

Het bovenstaande laat niet onverlet dat een hoofdcommissaris open kan staan voor vrijblijvend advies van de zijde van zijn politiecommissie. ${ }^{218}$ Politiecommissies zijn er vaak in geslaagd om bepaalde zaken door te spelen aan hoofdcommissarissen en op deze wijze hun mening kenbaar te maken. De hoofdcommissarissen zijn in veel gevallen ook uiterst tevreden over dit informele contact. Toch verhult deze situatie welke zaken in het bijzonder tussen hoofdcommissaris en politiecommissie besproken moeten worden. Het beleid van de hoofdcommissaris kan ten overstaan van de politiecommissies zowel open als gesloten zijn. De hoofdcommissaris maakt zelf uit welke informatie over het korps doorgespeeld wordt (mag worden) naar het betreffende politiecommissie. De omstandigheid dat een politiecommissie gebruik zal maken van de mogellikheid, geboden in artikel 12 van de Police Act 1964, om de hoofdcommissaris via de minister te dwingen een rapport op te stellen, is onwaarschijnlijk.

215. Greater London Council Police Committee, 1983, p. 31-32.

216. In Brogden, 1982, p. 77.

217. Brogden, 1982, p. 77.

218. Brogden, 1982, p. 78. Zie ook het interwiew met Chris Mullin in de bijlage. 


\subsection{Discretionair optreden}

\subsubsection{Inleiding}

De politieagent heeft een vergaande discretionaire bevoegdheid, hetgeen zich laat vertalen in een grote mate van onafhankelijkheid. Deze bevoegdheid neemt opvallend toe naarmate men de hiërarchische ladder afdaalt. Ditzelfde zien we ook in Nederland bij de informele sepotmogelijkheden van de agenten op straat, waarbij de agenten op eigen initiatief besluiten een door hen opgemerkt strafbaar feit niet te verbaliseren. Daar hoeft geen verantwoording over afgelegd te worden. Aangezien de lagere rangen over het algemeen meer dan de top van de politie met de burgers contact hebben, hebben zij ook vaker de mogelijkheid van hun discretionaire bevoegdheden gebruik te maken. Deze praktijk vindt zijn rechtvaardiging in de constabulary independence-theorie. ${ }^{219}$ Volgens deze theorie kan er slechts sprake zijn van een a-politieke en onpartijdige politiemacht, indien agenten op onafhankelijke wijze hum werk kunnen verrichten. De independence-leer brengt met zich mee dat agenten niet onderworpen zijn aan zowel de centrale als de lokale controle. De leer vloeit voort uit de verplichting van de agent de wet te handhaven binnen de bevoegdheden die de agent van dezelfde wet gekregen heeft. ${ }^{220}$ Desondanks kan er een kanttekening geplaatst worden: de constabulary independence-theorie staat nergens expliciet in de wet of de jurisprudentie beschreven. ${ }^{221}$ Toch zien we, zelfs in de jurisprudentie, dat men uitgaat van deze theorie. Het feit dat er in de wet of door common law de taken en bevoegdheden van politieagenten omschreven staan houdt met name in dat niet in strijd met deze regelingen bevelen kunnen worden gegeven aan agenten. Volgens Marshall kan hieruit niet afgeleid worden dat er een algemene onafhankelijkheid van gezag van buitenaf bestaat. 'In other words the absence of the common-law master-senvant relationship is not in itself sufficient to establish a general independence from all superior direction. ${ }^{\circ 222}$

In de rechtszaken Fisher v. Oldham Corporation en R. v. Metropolitan Police Commissioner, ex parte Blackburn zijn de rechters ervan uitgegaan dat de onafhankelijkheid van de politieagent als zodanig bestaat en vaststaat. Marshall is van mening dat de rechters in deze zaken niet eens het onderwerp van de onafhankelijkheid hadden hoeven aan te stippen, aangezien de zaken de rechterlijke controle over de discretionaire bevoegdheid van de

219. Reiner, 1994, p. 742.

220. Jefferson en Grimshaw 1982 , p. 84.

221. In Groot-Brittannië zijn er vaak ongeschreven regels: common law. Marshall, 1965, p. 253; zie ook Goldsmith, 1991, p. 2-3

222. Marshall, 1965, p. 253. 
politieagenten aan de orde stelden. ${ }^{23}$ Desalniettemin wordt de constabula7 independence tegenwoordig als een onbetwistbaar punt aanvaard.

\subsubsection{Fisher v. Oldham Corporation (1930) $2 \mathrm{~KB} 364$}

In de zaak van Fisher v. Oldham Corporation werd voor het eerst over de verhouding tussen politiecommissies en hoofdcommissarissen beslist. In deze zaak werd een inwoner van Oldham (eiser) verdacht van het onder valse voorwendselen verkrijgen van $\mathbf{1 5 0}$ (Pond Stering). De man was een bekende van de politie en al verscheidene keren veroordeeld vanwege hetzelfde delict. Hij werd gearresteerd in Londen; een nacht in hechtenis gehouden; overgebracht naar Oldham en nog enkele uren vastgehouden, alvorens men tot de ontdekking kwam dat hun verdachte niet de gezochte man was en vrijgelaten werd. Daarop spande de man een procedure aan vanwege 'onterechte gevangenhouding' tegen de wath committee of the borough corporation van Oldham. De gedaagde stelde dat de commissie niet aansprakelijk kon worden gesteld voor deze actie van de Oldhamse politie.

Voor de 'King 's Bench Division' (van the High Court of Justice: een rechtbank voor zee- en handelsrecht en privé-vorderingen) was derhalve de vraag aan de orde of een politiecommissie aansprakelijk kon worden gesteld voor een 'onterechte gevangenhouding' van een burger gedaan door ển van zijn politieagenten. Concreet werd m.a.w. de vraag voorgelegd aan het hof hoe de betrekkingen gezien moeten worden tussen de politie en de lokale autoriteiten. De Municipal Corporations Act 1882 gaf de watch commintee slechts beperkte bevoegdheden. Een agent behoefde op grond van art. 191. van die wet slechts bevelen op te volgen van een justice of the peace (een vrederechter), en niet van een watch committee. Op grond hiervan kwam McCardie $\mathrm{J}^{224}$, rechter in deze zaak, tot het oordeel dat een pollitieagent niet beschouwd kon worden als beambte in dienst van de gemeente. Een agent is dienaar van de staat en van het centraal gezag, die in enkele opzichten onderworpen is aan lokaal toezicht en an lokale regelingen. McCardie J. besliste namens het hof dat de politiecommissie - al kon de commissie be schouwd worden als de werkgever van de politie - niet aansprakelijk was, aangezien de politieagent niet gehandeld had als dienaar of vertegenwoordiger van de politiecommissie. De politie vervulde haar plicht als dienaar van de Kroon; "to preserve the peace by day and by night, to prevent robberies and other felonies and misdenteanors and to apprehend offenders against the peace.' De rechter besloot zijn oordeel met de volgende overweging: "If local authorities are to be liable in such a case as this ... then it mould indeed be a serious matter and it would entitle them to demand that they

223. Marshall, 1965, p. 255.

224. Justice. 
ought to secure a full measure of control over the arrest and prosecution of all offenders. To give any such control would, in my view, involve a grave and most dangerous constitutional change. ${ }^{225}$ Met andere woorden als aan de politiecommissie meer democratische controle gegeven zou worden dan zou de grondwettelijke en legale status van de politie veranderd moeten worden.

\subsubsection{R v. Met. Police Comr. ex p. Blackburn (1968) 2 QB 118, (1968) 1 All ER 763}

In Groot-Brittannië was in de jaren zestig het gokken in gokhuizen waarbij geen gelijke kansen geboden werden aan de deelnemers strafbaar gesteld. In april 1966 werd in een vertrouwelijk schrijven aan commissarissen van de Metropolitan Police medegedeeld dat bij overtredingen van deze bepalingen slechts tot actie overgegaan hoefde te worden als er klachten van bedrog waren ingediend of als de gokhuizen een veel bezochte plaats van misdadigers werden. Een zuivere beleidsbeslissing derhalve, waarover een politiecommissie vragen zou kunnen stellen. De heer Blackburn bemerkte dat de politie inactief was bij de naleving van de betreffende bepalingen. Dit zat hem erg dwars. Blackburn was de mening toegedaan dat de beslissing van de politie om niet tot vervolging over te gaan, wanneer overtredingen door de politie geconstateerd waren, niet juist was. Het was de plicht van de commissioner om te vervolgen. Blackburn beweerde dat aangezien de hoofdcommissaris aan geen enkel politiek gezag verantwoording verschuldigd was, hij verantwoording verschuldigd moest zijn aan de wet, i.c. de rechtbank. Zou dit niet het geval zijn, dan zou de commissaris aan niemand verantwoonding moeten affeggen. Op de problematiek met betrekking tot deze zaak zijn de rechters uitvoerig ingegaan.

Lord Denning MR ${ }^{226}$ verklaarde allereerst dat de commissioner, net als elke agent in Groot-Brittannië, onafhankelijk is van de uitvoerende macht. Hij is niet onderworpen aan bevelen van de minister van het Home Office, daargelaten dat hij weliswaar gevolg moet geven aan het verzoek van de minister een rapport op te stellen of in het belang van de efficiëntie het korps te verlaten. De commissioner heeft evenals de andere hoofdcommissarissen de taak de wet te handhaven. "The responsibility for law enforcement lies on him. He is answerable to the law and to the law alone. ${ }^{227}$ Volgens Lord Denning bleek dit overduidelijk uit Fisher v. Oldham Corporation.

225. (1930) $2 \mathrm{~KB} 377-378$.

226. Master of the Rols = soort president van de Civil Division, het Engelse Hof van Beroep.

227. $R$ v. Metropalitan Police Commissioner, ex parte Blackbum, All ER (1968) p. 769: zic ook Reiner. 1994. p. 742-743. 
Lord Denning zei vervolgens in zijn uitspraak dat ofschoon de hoofdcommissarissen verantwoording verschuldigd zijn jegens de wet, zij op vele gebieden een zekere vrijheid genieten, met welke zaken de wet zich niet bemoeit. Bijwoorbeeld of er al dan niet in een specifiek geval tot een arrestatie zal worden overgegaan. De hoofdcommissaris is ook vaak vrij beleidsbeslissingen te nemen. In enkele gevallen echter kan een dergelijke beslissing toch onderworpen worden aan rechterlijke toetsing. Lord Denning noemde hierbij het voorbeeld van een hoofdcommissaris die zijn agenten de richtlijn zou geven niemand te vervolgen wegens diefstal als de gestolen goederen een waarde hebben van minder dan 1100 . In dit geval zou de hoofdcommissaris zijn taak niet vervullen om de wet te handhaven en de rechter zou derhalve die beslissing kunnen herroepen.

\subsubsection{Rv. Metropolitan Police Comr, ex p. Blackburn (1973) QB 241, (1973) I All ER 324}

De heer Blackburn liet het niet hierbij. In 1972 verzochten hij en zijn vrouw aan de rechters de politie op te dragen effectiever de wet te handhaven waar het de bestrijding van pornografie betrof. Pornografische literatuur was in enkele wijken in Londen in zeer grote mate verkrijgbaar en de politie ondernam geen enkele actie hiertegen, zo stelde Blackburn. In Londen had de politie opdracht gekregen geen zaak te beginnen tegen overtredingen van de Obscene Publications Act 1959 zonder dat de toestemming hiervoor van de Director of Public Prosecutions (het hoofd van het Britse Openbaar Ministerie; zie hierover verder) was verkregen. Deze maatregel was genomen omdat de politje eerder geprobeerd had dergelijke zaken woor de rechter te brengen, met als resultaat dat het bewijs in deze zaken nooit voldoende was voor een veroordeling. Wanneer de politie pornografie constateerde, moest het geval voorgelegd worden aan de Director of Public Prosecutions die òf zelf een vervolging zou beginnen òf het aan de politie zou overlaten via een dagvaarding de zaak woor te leggen aan de Magistrates' Court teneinde het pornografische materiaal verbeurd te verklaren.

Het hof (Cownt of Appeal) in deze zaak was van mening dat de pogingen van de politie om pornografie tegen te gaan inderdaad ineffectief waren. Echter, dit was niet zozeer aan de politie te wijten dan wel aan de zwakke Obscene Publications Act 1959 en aan her kader waarin de politie moest optreden. Derhalwe kon niet gezegd worden dat de politie in haar taak gefaald had. De commissioner had volgens Lord Denning MR alles gedaan wat van hem redelijkerwijs verwacht kon worden in de bestrijding van pornografie.

Het Court of Appeal besliste dat de rechters pas tussenbeide komen als de hoofdcommissarissen hun verantwoordelijkheid jegens wetshandhaving van zich afgeschoven hebben. Lord Denning MR: ' $I n R \vee$ Metropolitan Police 
Commissioner, ex parte Blackburn ${ }^{228}$ we made it clear that, in the carrying out of their duty of enforcing the law, the police have a discretion with which the courts will not interfere. There might, however, be extreme cases in which he was not carrying out his duty. And then we would." 229

Zolang de politie haar taak naar behoren vervulde, kon de rechtbank zich niet bemoeien met hun beslissingsbevoegdheid. ${ }^{230}$ Het bevelschrift (order for mandamus) om de politie op te dragen om de pornografie te bestrijden werd derhalve geweigerd. Een gelijksoortige uitspraak vinden we ook nog later in $R$. v. Chief Constable of the Devon and Cornwall Constabulary, ex parte Central Electricity Generating Board (1981) 3 All ER 826. Uit al deze uitspraken kunnen we affeiden dat de Court of Appeal (maar ook andere rechters) zich terughoudend opstelt en de politie een grote beleidsruimte laat.

\subsection{De inspecteurs van het Home Office}

De Koningin kan een aantal inspecteurs benoemen ${ }^{231}$. Dit aantal wordt door de minister wan het Home Office vastgesteld. De takak van de inspecteurs is het inspecteren van en het rapporteren aan de minister over de doelmatigheid van politiekorpsen. Reden om het Inspectorate op te richten was de behoefte aan een effectieve centrale controle over de regionale politiedoeleinden in de verscheidene korpsen. ${ }^{232}$ Het doel van de inspectie is om een korps voor te leggen aan de Home Office Grant, i.e. een dienst binnen het ministerie die beslist over de jaarlijkse financiële toelage. 'The primary function of the Inspector is to advise the Home Secretary whether the forces were maintained efficiently so that they qualified for the Exchequer Grant. ${ }^{233}$ De Metropolitan Police hoeft niet geïnspecteerd te worden, omdat ze niet op de hierboven beschreven wijze een toelage krijgt van het ministerie.

De inspecteurs vormen de voornaamste link tussen het ministerie en de provinciale politiekorpsen. Hun adwies wordt cruciaal geacht voor de be-

228. (1968) 1 All ER op p. 769.

229. $R$ V Metropolitan Police Commissioner, ex parte Blackbum and another (no 3) (1973) 1 All ER, p. 331.

230. Zie Wade, 1988, p. 404.

231. Zie art. 38 Police Act 1964.

De eerste HM Inspectors of Constabulary werden benoemd in 1856. Dit geschiedde gelijktijdig met het geven van een toelage van de Central Exchequer van $25 \%$ aan de politiecommissies.

232. Lambert. 1986.

233. Lord Horsham van het Home Office in 1958; zie Brogden, 1982, p. 112. 
leidsvorming binnen het ministerie. De hoofdinspecteur is een belangrijke adviseur van de Home Secretary over politiezaken. De hoofdinspecteur heeft de beschikking over zeven assistenten. Eén houdt zich bezig op het terrein van misdaad, verkeer en gemeenschapsbetrekkingen. Een andere inspecteur is werkzaam op het gebied van het management, de communicaties, de training en informatiediensten.

Het onderzoek van de inspecteurs beperkt zich tot de organisatie en de procedurele wijze van wetshandhaving. De bekwaamheid van de hoofdcommissaris maakt deel uit van het onderzoek. Echter, politiemisbruik dat geen aanleiding is geweest tot een klacht wan burgers is weer geen onderwerp van onderzoek, tenzij dit handelen effect heeft op de algehele optreden, i.e. efficiëntie, van het korps. Een inspecteur heeft weinig te zeggen over de financiële aspecten van het politieoptreden.

De inspecteurs rapporteren aan de hoofdcommissarissen, die de informatie verder doorspelen aan de minister. Zij rapporteren dus niet rechistreeks aan de minister zelf. Een negatief advies van een inspecteur aan de minister kan een intrekking van de financiële taelage tot gevolg hebben. Dit controleinstrument is grotendeels ten dode opgeschreven. In het verleden is het zelfs als zodanig nooit tegen een hoofdcommissaris gebruikt. Zo verwonderlijk is dit niet als men bedenkt dat de inspecteurs voornamelijk uit de kringen van hoofdcommissarissen worden benoemd. ${ }^{234}$ De inspecteurs zitten vaak op dezelfde lijn als de hoofdcommissarissen. In de gevallen dat deze sanctie gebruikt werd, was het voornamelijk gericht tegen de lokale watch committee. Sinds 1964 is het weinig zinvol om dit instrument te gebruiken tegen een politiecommissie teneinde de efficiëntie te verhogen, aangezien deze commissie feitelijk weinig te zeggen heeft over het operationeel beleid van het politiekorps. Als er al een politiek conflict is tussen een politiecommissie en zijn hoofdcommissaris, dan zal de inspecteur in veel gevallen de hoofdcommissaris steunen tegenover de buitenwereld. De meeste inspecteurs zijn wel bereid tijdens hun inspectie een algemene evaluatie te houden met leden van de commissie. Echter hun rapporten worden nooit openbaar gemaakt, zelfs niet tegenover commissieleden. Deze rapporten bevatten niet altijd vleiende informatie over de plaatselijke hoofdcommissaris en zijn assistenten. Het Inspectorate heeft niet zo'n groot vertrouwen in de geheimhoudingsplicht van de raadsleden dat zij de inhoud van deze rapporten willen toevertrouwen aan de leden. ${ }^{235}$

De inspecteurs spelen een duidelijke rol bij het stimuleren van samenwerkingsverbanden tussen korpsen. De ontwikkeling van Regional Crime 
Squads (regionale misdaadbrigades) is bijvoorbeeld een gevolg van een dergelijke activiteit van het Inspectorate. ${ }^{236} \mathrm{Na}$ het invoeren van de samenvoegingsprogramma's van de jaren zestig, hebben enkele gefuseerde korpsen de nieuwe functie van een corporate manager in het leven geroepen. Dit heeft een deel van het werk van de inspecteurs overbodig gemaakt.

\subsection{Richtlijnen van het ministerie}

De circulars ofwel richtlijnen lijken de enige mogelijkheid voor de minister om invloed uit te oefenen op het beleid van de hoofdcommissarissen. ${ }^{237}$ Brogden stelt in zijn boek uit 1982 dat de minister jaarlijks zo'n 100 richtlijnen aan het politieapparaat geeft. ${ }^{238}$ Over de inhoud van een richtlijn heeft het parlement niets te zeggen, aangezien het technisch gezien niet als wetgeving beschouwd kan worden ${ }^{239}$. Een circular heeft in de praktijk wel bijna hetzelfde gezag als dat van een wet. Critchley verwoordt het aldus: "... the profilic "advice" and "guidance" contained in the Home Office circulars became a euphemism for "direction" 240 De minister van het Home Office zei in 1979 hierover: "Circulars or memorandum issued by my Department for the guidance of chief officers of the police do not have the force of law ... but may, where appropriate, contain advice on the exercise of discretionary powers conferred by Parliament. ${ }^{241}$

Richtlijnen van het departement kunnen beschouwd worden als normale administratieve documenten waarbij instructies verspreid worden. Veel richtlijnen worden gepubliceerd in staatsbladen en bevatten algemene beleidsverklaringen. Deze richtlijnen gaan vaak vergezeld van persberichten. ${ }^{242}$ Vandaar dat zij als belangrijk worden ervaren door het publiek. Zij geven immers aan hoe de organisatie van overheidsdiensten in elkaar zit en welke bevoegdheden de verschillende diensten bezitten.

\subsubsection{Inhoud van de circulaires}

Richtlijnen van het ministerie kunnen administratieve instructies en wetgevend advies bevatten. Rechters moeten rekening houden met richtlijnen die

236. Brogden, 1982, p. 113.

237. Lustgarten, 1986, p. 105. lets soortgelijks vinden wij ook in Nederland. Door middel van richtlijnen vindt hier regelmatig contact plats tussen politie en ministerie. Zij worden gepubliceerd in de Staatscourant.

238. Brogden, 1982, p. 114.

239. Lustgarten, 1986, p. 105.

240. Critchley, 1979 , p. 219.

241. Brogden, 1982, p. 115.

242. Lustgarten, 1986, p. 105. 
wetgevend advies bevatten. Vaak zal het moeilijk zijn uit te maken of elementen van een circular wetgevend zijn of slechts administratieve informatie en/of advies bevatten. De richtlijnen die administratieve instructies bevatten, informeren de politie over de hoogtes van de salarissen, over de betaling van overuren etc. Het betreft hier informatie waarover overeenstemming is bereikt door de politieraad (Police Council, tegenwoordig de Police Negotiating Board) en de centrale overheid.

Het andere soort circulaires heeft meer een sturende reikwijdte. Nieuwe initiatieven wanuit de regering worden hierin aangekondigd. Bij nieuwe wetgeving kan via een circulaire aan de politie doorgegeven worden op welke manier de wet ingevoerd moet worden. Vóór het uitzenden van een circulaire wordt over het algemeen advies gevraagd aan de Association of Chief Police Officers (de organisatie waarin alle hoofdcommissarissen, vervangend-hoofdcommissarissen en assistent-hoofdcommissarissen verenigd zijn), hierna ACPO genoemd.

Van een hièrarchische bevelsrelatie tussen het ministerie en de politiekorpsen kan niet echt gesproken worden. ${ }^{243}$ De vraag kan gesteld worden in hoeverre het politieapparaat gehouden is bevelen op te volgen van het ministerie. Heeft een circular een bindende werking? Een voorbeeld uit de recente Engelse geschiedenis kan deze vraag illustreren.

In 1983 vaardigde het Home Office een richtlijn (circular 47/83) uit over de omstandigheden van uitgifte en het gebruik van vuurwapens van de politie naar aanleiding van het per ongeluk neerschieten van een zekere Steven Waldorf door twee agenten van de Metropolitan Police ${ }^{244}$. Deze richtlijn bevatte de bepaling dat vuurwapens alleen als laatste middel door goed getrainde agenten gebruikt mochten worden. Daarnaast was het dragen van vuurwapens alleen toegestaan aan senior agenten. In 1984 werd in Essex een agent neergeschoten door een bankovervaller. De hoofdcommissaris van Essex beklaagde zich na dit incident erover dat de richtlijnen van de circular zijn agenten in een onmogelijke situatie hadden gebracht. Kenmerkend van dit geval was dat de hoofdcommissaris zich gebonden woelde aan de circu-

243. Een financiële relatie kan daarentegen wel gesignaleerd worden, maar dit verband werkt slechts indirect.

244. In januari 1983 werd in Londen een auto, waarin o.a. Steven Waldorf zat, beschoten door agenten. Deze agenten waren van de veronderstelling uitgegaan dat David Martin zich in de auto bevond, die gezocht werd voor enkele ernstige misdrijven. Waldorf werd ernstig verwond. Deze zaak riep vragen op over het gebruik van vuurwapens door de politie. De twee agenten werden vanwege de schietpartij vervolgd wegens poging tot moord. Uiteindelijk werden zij niet schuldig bevonden. Zie Scraton, 1985, p. 40. 
lar, ondanks de bezwaren die hij daartegen had. Het idee dat hij in dit geval zijn onafhankelijkheid als hoofdcommissaris kon benutten en derhalve circular $47 / 83$ kon negeren schijnt nooit bij hem opgekomen te zijn. ${ }^{245}$ Zou het niet mogelijk zijn dat langzaam maar zeker (onbewust) de erkenning van het centrale gezag zich deed gelden?

Uit dit voorbeeld kan men afleiden dat hoofdcommissarissen zich gebonden voelen rekening te houden met de inhoud van richtlijnen van overheidswege. Het feit dat de richtijnen in sommige gevallen het product van het proces van consultatie zijn tussen de overheid en het $\mathrm{ACPO}$, de organisatie waarin alle hoofdcommissarissen in verenigd zijn, kan hiervoor een verklaring zijn. ${ }^{246}$

De hoofdcommissaris van Manchester, James Anderton, handelde daarentegen in 1984 wel geheel zelfstandig. Ter bestrijding van gewapende overvallen had hij aangekondigd dat gewapende agenten 24 uur per dag zouden patrouilleren in politieauto's door de straten van Manchester. Deze maatregel ging volledig in tegen de richtlijn van de Home Secretary Whitelaw. Het Home Office werd om opheldering verzocht. Vanuit dit ministerie kwam het antwoord dat het al dan niet bewapenen van agenten een operationele beleidszaak was en dientengevolge onder de bevoegdheid van de hoofdcommissaris viel. ${ }^{247}$

In de jurisprudentie is bovengenoemd probleem ook aan de orde gekomen. Rechters hebben de oplossing trachten te vinden in de toekenning van functies. In bijwoorbeeld de rechtszaak van Laker, besliste de rechtbank dat de ministeriële richtlijn in dat specifieke geval eerder adviserend van aard was dan een bindende werking had (Laker Airways v. Department of Trade (1977) $Q B$ 643). ${ }^{248}$ In 1980 zei Leon Brittan, Minister of State ${ }^{249}$ van het Home Office het volgende over operationele aanwijzingen aan het politieapparaat van de minister: "I have emphasised that chief constables are operationally independent. The Home Secretary cannot give them instructions on whether or not to institute proceedings in any particular case etc. ${ }^{250}$

245. Lustgarten, 1986, p. 105-106.

246. Lustgarten, 1986, p. 106.

247. Scraton, 1985, p. 40-41.

248. Harlow en Rawlings, 1984, p. 131.

249. Een Mimister of State kan gelijkgesteld worden aan een staatssecretaris.

250. Hoewel je je kunt afvragen of hij dat telefonisch toch niet stiekem doet. Greater London Council, 1983, p. 30. 


\subsection{Afronding: verantwoording}

We hebben hierboven gezien hoe het gesteld is met de onafhankelijkheid van de politie in Engeland en Wales. De agent hoeft geen verantwoording aan politiecommissies, het parlement of de minister af te leggen. Voor Londen geldt er echter weer een uitzondering. ${ }^{25 !}$ In dit geval wordt de Police Authority gevormd door de Home Secretary ${ }^{252}$. Deze is voor het functioneren van de Metropolitan Police verantwoording verschuldigd aan het parlement. Dit leidt tot de merkwaardige situatie dat de minister in het parlement ter verantwoording kan worden geroepen over zaken van law and order, terwijl hij feitelijk geen invloed kan uitoefenen op de policy and operational decisions van het politiekorps in Londen. De verantwoordelijkheid die de minister tegenover het parlement moet afleggen, is groter dan zijn zeggenschap over het politieapparaat. Immers de enige controle die hij over de politie kan uitoefenen, bestaat uit het doen instellen van een onderzoek en hoofdcommissarissen te verzoeken daarover een rapport op te stellen. Het parlement kan hem voor het uitoefenen van deze beperkte zeggenschap niet ter verantwoording roepen, omdat de rapporten in naam van het algemeen belang niet openbaar zijn.

De onafhankelijkheid van de politie en de ontstentenis van de plicht om aan regering en parlement verantwoording af te leggen voor het politieoptreden, kan echter tot misbruik leiden. De controle over het optreden is immers niet aanwezig. De plicht om intern verantwoording af te leggen binnen het politiebestel is niet altijd een voldoende waarborg tegen dit misbruik. In de wet is de mogelijkheid ingeruimd dat individuele burgers klachten over politieoptreden kunnen neerleggen bij de hoofdcommissaris. De hoofdcommissaris bekijkt of er strafrechtelijk dan wel disciplinair moet worden opgetreden. Bij gegrondverklaring van een klacht kunnen tegen agenten disciplinaire of strafrechtelijke maatregelen worden genomen. De wergaande onafhankelijkheid van de politieagent impliceert dat de minister en politiecommissies zich dienen te onthouden van inmenging in operationele aangelegenheden. In de rechtspraak is, zoals al hierboven gesteld, deze onafhankelijkheid voor agenten herhaaldelijk erkend. Helaas bestaat er dus geen mogelijkheid om tegen gevoerd beleid of beleidsplannen een klacht in te dienen. De doelma-

251. Terwijl voor de City of London weer een andere regeling geldt. Londen heeft namelijk twee politiekorpsen: De Metropolitan Police en de City of London Police. De Ciry of London Force is verantwoording verschuldigd aan de Common Council of the City of London (the Aldermen and Mayor). Reiner. 1994, p. 749 .

252. Dit is de minister van Birnenlandse Zaken, het Home Office. 
tigheid van de klachtenprocedure is al onderwerp wan onderzoek geweest. ${ }^{253}$

In dit hoofdstuk is de verhouding politie - overheid besproken. Uit deze verhouding blijkt dat de politie op dit moment sterk staat en veel beleidsvrijheid heefi. De mogelijkheid dat het ontbreken van verantwoording kan leiden tot misbruik komt aan de orde in de volgende vijf hoofdstukken.

253. British Crime Survey. 


\section{Causes cêlèbres: the Royal Commission on the Police}

\subsection{Inleiding}

In januari 1960 werd in Engeland en Wales de Royal Commission on the Police ingesteld. In de jaren vóór 1960 vonden er gebeurtenissen plaats die een aanleiding vormden voor onderzoek naar het functioneren van de politie. ${ }^{254}$

De naoorlogse politiekorpsen in Engeland en Wales verkeerden rond de jaren zestig in problemen. Lange tijd vóór 1960 was er een stijging van het aantal misdaden waar te nemen. De toename van het verkeer gaf de politie handemvol werk en was bovendien aanleiding voor organisationele problemen. De onvrede binnen het politiekorps vanwege deze redenen en vanwege het lage loon was groot, hetgeen zich uitte in een groot verloop van - vooral ervaren - agenten. ${ }^{255}$ Een uitbreiding van het politieapparaat leek voor de hand te liggen. De economische situatie van het land was evenwel op dat moment slecht. De regering wilde deze problemen zonder degelijk onderzoek miet trachten op te lossen door verhoogde uitgaven te doen ten voordele van de politie. ${ }^{256}$

Daarnaast bestond er een grote bezorgdheid over de relatie tussen de politie en het publiek. Aanleiding daarvoor was een aantal op zichzelf staande incidenten in de jaren '50, die de naam van de politie in diskrediet hadden gebracht. Deze incidenten stelden ook het probleem van de verantwoordelijkheid van de politieagent ten opzichte van zijn baas en ten opzichte van de maatschappij aan de kaak.

\subsection{Incidenten}

Volgens Critchley kunnen de moeilijkheden in 1956 in een politiekorps in Cardiganshire als het begin genoemd worden van de aantasting van het vertrouwen van de burgers in de politie. ${ }^{257}$ Het korps in Cardiganshire werd niet goed geleid door de plaatselijke hoofdcommissaris. Scott Henderson en Phillimore verrichtten beiden afzonderlijk onderzoek naar de leiding

254. Royal Commission on the Police, 1962, p. 4.

255. De onvrede uitte zich op twee niveaus: an de top was er ontevredenheid over de wergoeding van hun functie als leider wan cen grote organisatie en aan de basis was er onvrede over de verhouding tot het publiek over de zaken Thurso en Rix, waatdoor er kJachten bij de organisatie binnenkwamen. Zie werder.

256. Critchley* 1979, p. 264-266.

257. Critchley, 1979, p. 270; zie ook Reiner, 1994, p. 710-711. 
van dit korps op verzoek van de politiecommissie in Cardigan. ${ }^{258}$ Het resultaat van deze onderzoeken was de samenwoeging van dit korps in Cardigan met het korps van Carmarthenshire. Deze gebeurtenis ging niet over een nacht ijs, aangezien in het House of Commons veel weerstand bestond tegen de samenwoeging. Het grote kritiekpunt was dat de betreffende politiecommissies over een eventuele samenvoeging niet geconsulteerd waren. ${ }^{259}$

Dit incident werd in 1957 gewolgd door een drietal andere gebeurtenissen. De hoofdcommissaris van het politiekorps in Brighton werd verdacht van corruptie en de hoofdcommissaris van het korps in Worchester werd veroordeeld woor fraude. In 1957 deden eveneens geruchten de ronde waarin de suggestie gewekt werd dat een jongen in Thurso (Schotland) slachtoffer was geworden van mishandeling door een politieagent. Kritiek ontstond in Groot-Brittannie toen dit niet behoorlijk onderzocht werd.

In 1959 tenslotte schorste de politiecommissie van Nottingham ten onrechte hatar hoofdcommissaris. Staatssecretaris Butler van het Home Office kwam in dit geval tussenbeide. ${ }^{260} \mathrm{Hij}$ was van oordeel dat op grond van de rechtszaken Fisher v. Oldham Corporation (1930) 2 K.B. 364 en AttomeyGeneral for New South Wales v. Perpetual Trustee Co Ltd (1955) A.C. 457, de Watch Committee geen recht had zich te bemoeien met het beleid van de hoofdcommissaris inzake het uitoefenen van de strafwet. Dit incident richtte duidelijk de aandacht op de tekortkomingen van de wettelijke regeling op het gebied van de functieomschrijvingen wan Police Awthorities en hoofdcommissarissen.

\subsection{Reactie van het parlement}

In 1959 vonden er debatten plaats in het Lagerhuis waaruit kritiek op het gedrag van de minister in zijn wijze van afhandeling van politiezaken bleek. ${ }^{261}$ Deze debatten toonden weer aan dat er een duidelijk gebrek aan

258. 589, H.C. Deb., 5th Ser., kolom 832 .

259. Zie 0.a. 589 , H.C. Deb., Sth Ser, kolommen 826-852.

260. 609, H.C. Deb., 5th Ser, written answers kolommen 52-53; 610, H.C. Deb., 5th Ser. kolommen 682-683.

261. In het Oxford Handboak of Criminology geeft Reiner de volgende achtergrondinformatie: "There were three cases of criminal or disciplinary proceedings against chief constables. These were not the serious matters they might appear at first sight. They occurred in small borough forces which today would constitute at most divisions, within the large forces with which we are familiar. The contemporary equivalents of the chief constables implicated would be chief superintendents or lower-ranked officers. The immediate trigger for the Royal 
het afleggen van verantwoording bij de politie bestond, dat vragen werden gesteld over haar constitutionele positie in de staat en dat de geschiktheid van de politie om klachten afdoende te behandelen in twijfel getrokken werd. ${ }^{262}$ Dit alles was er de oorzaak van dat er een groeiende ontevredenheid onder parlementsleden ontstond over de effectiviteit van het politieoptreden, welke ontevredenheid door de afwezigheid van een verantwoordingsplicht wan agenten nog eens benadrukt werd. Het parlement beschikte wel over de mogelijkheid incidenten binnen de Metropolitan Police aan de orde te stellen en de minister hierover ter verantwoording te roepen. In de lloop der tijd heeft het parlement getracht zijn invloed op provinciale ${ }^{263}$ politieaangelegenheden te doen gelden door de minister van het Home Office vragen over deze zaken te stellen. In het boek van Erskine May wordt hierover het volgende gezegd: Vragen aan de minister 'should relate to the public affairs with which the ministers are afficially connected ... or to matters of administration for which they are responsible 264 en tussen de lijst van vragen die niet toegelaten zijn, staan 'matters under the control of local or other statutory authorities' ${ }^{265}$ Onder de omschrijving 'local authority' valt de 'provincial police. ${ }^{266}$ Hieruit blijkt dat parlementsleden niet over de mogelijkheid beschikken lokale politieaangelegenheden aan de orde te stellen in het parlement.

De bezorgdheid over de middelen om de politie te beheersen en de onvrede over de onmacht de politie ter verantwoording te roepen als zaken uit de hand liepen, waren derhalve redenen tot het instelten van de Royal Commission. Vooral het laatste argument had, zoals hierboven al vermeld, tor gevolg dat er onvrede bestond over de afhandeling van klachten van burgers en over de constitutionele positie van de politieagenten binnen de staat. In de Police Act vóór 1964 was de rol van de politie niet omschreven ${ }^{267}$ In

$2611 . \rightarrow$

Commission was a parliamentary debate arising out of an altercation at a traffic incident in Hyde Park in which the famous star of Whitehall farces, Brian Rix, became involved.' Reiner, 1994, p. 711, nt. 4.

262. 585, H.C. Deb., 5th Ser, kolommen 569-571; 586, H.C. Deb., 5th Ser., kolommen 1293-1295; en 613, H.C. deb., Sth Ser., kolommen 1239-1303.

263. D.w.z. provinciaal in de Engelse betekenis: provincial.

264. May, 1983, p. 336.

265. May, 1983, p. 340.

266. May, 16th edition, p. 360 .

267. In de Police Act van Schotland wel:

- . to guard, patrol and watch, so as -

1) to prevent the commission of offences against the law;

2) to preserve order; and

3) to protect life and property.' (zie art. 4 van de Police [Scotland] ACt 1956). 
het kort komt het erop neer dat er behoefte was aan een herdefinitie van de staatsrechtelijke positie van de politie die acceptabel zou zijn voor het Britse parlement. ${ }^{268}$

\subsection{Instelling van een Commissie}

Op 16 december 1959 kondigde de Prime Minister Mr. Harold Macmillan de instelling van een Rayal Commission aan. ${ }^{26 \%}$ Sir Henry Willink werd benoemd tot woorzitter van de Royal Commission. De commissie kreeg wan de regering als taakomschrijving mee:

'To review the constitutional position of the police througout Great Britain. the arrangements for their control and administration and, in particular, to consider:

1) the constitution and functions of local police authorities;

2) the status and accountability of members of police forces, including chief officers of poilice;

3) the relationship of the police with the public and the means of ensuring that complaints by the public against the police are effectively dealt with; and

4) the broad principles which should govern the remuneration of the constable, having regard to the nature and extent of police duties and responsibilities and the need to attract and retain an adequate number of recruits with the proper qualifications. ${ }^{370}$

Aan het einde van 1960 , in november, had de commissie al een interimrapport klaar over de salariëring van de politieagenten. ${ }^{271}$ Dit geheel tot tevredenheid van de politiebonden, die de commissie verzocht had aan dit punt als eerste aandacht te schenken. ${ }^{272}$ De commissie kwam tot de con-

268. Critchley, 1979, p. 274

269. In mei 1959 dacht Home Secretary Butler er nog niet over om een Royal Commission in te stellen. Zie 605, H.C. Deb. Sth Ser, writen answers kolommen $67-68$.

270. Final Repont van de Royal Commission on the Police, 1962, p. iv; 615, H.C. Deb., 5th Ser., kolom 1452.

271. De commissie heeft in haar twee rapporten, waarwan het interim-rapport er een is, de gehele organisatie wan de politie bellandeld. In het kader van dit boek zal ik slechts aan een paar aspecten aandacht besteden, waarvan ik meen dat ze relevant zijn.

272. Mr. Gordon Walker, MP, had op 16 december 1959 hierover in het parlement al een vraag gesteld aan de Prime Minister. Deze laatste had de toezegging 
clusie dat het pollitiekorps een tekort van nagenoeg 13.500 mensen had. Dit aantal kwam toentertijd neer op $14 \%$ van de helle politieorganisatie. Als reden voor dit tekort gaf de commissie aan dat de politie een belangrijk deel van haar aantrekkingskracht verloren had. De agenten werden voor hun werk zeer slecht betaald. Voornaamste oplossing zou een salariswerhoging moeten zijn. Zowel de regering als de lokale Police Authorities waren van mening dat de voorstellen van de commissie onmiddellijk ingevoerd zouden moeten worden. Binnen korte tijd bleek hoe succesvol dit was. Het werven van nieuwe agenten verliep vlot en de moral binnen de korpsen verbeter$\mathrm{de}^{273}$

\subsection{Het eindrapport van de Royal Commission}

In de media bestond de algemene indruk dat de relatie tussen politie en publiek een dieptepunt had bereikt. ${ }^{274} \mathrm{Na}$ enig onderzoek kwam de commissie echter tot de conclusie dat hiervan in de praktijk geen sprake was. Aan enkele incidenten hadden de media, volgens de commissie, de gedachte toegedicht dat politie en publiek op slechte voet met elkaar stonden. ${ }^{275}$ Vanwege deze berichtgeving in de pers namen veel mensen dit voor waar aan. Het feit echter dat deze berichtgeving niet in twijfel getrokken werd, was wel voor de commissie aanleiding om eens goed naar de (positie van de) politie te kijken. ${ }^{276}$

De commissie was van mening dat een zekere eenheid in thet politiebestel noodzakelijk was. Deze eenheid zou te verwezenlijken zijn door de politie onder een sterkere centralle controle te plaatsen en de minister van het Home Office meer additionele bevoegdheden te geven. Dit laatste zou o.a. gestalte moeten krijgen in een uitbreiding van de bevoegdheden die de minister tot die tijd had. Alle voorstellen van de commissie wezen op een verschuiving van de balans van een lokale naar een centrale verantwoordelijkheid woor de politie.

De commissie kwam tot de conclusie dat de controle over de politie in feite de controle over de hoofdcommissaris betekende. De hoofdcommissaris zou onderworpen moeten worden aan een effectiever toezicht. De commissie

272. $\rightarrow$

gedaan de vraag voor te leggen aan de commissie. Zie 615, H.C. Deb. 5th Ser., kolommen 1452-1455.

273. Critchley, 1979, p. 278.

274. Royal Commission on the Police, 1962, p. 5.

275. Toen al!

276. Royal Commission on the Police, 1962, p. 5. 
stuitte hierbij wel op een probleem: hoe deze conclusie te verwezenlijken. ${ }^{2 n}$

\subsubsection{Een nationaal politiekorps?}

Een van de mogelijke oplossingen zou de inwoering zijn van een nationaal politiekorps. De invoering van een dergelijk systeem zou namelijk bepaalde voordelen hebben: Controle vanuit het parlement die de verantwoordelijke minister ter verantwoording zou kunnen roepen en controle door de minister van de politiekorpsen en hun hoofdcommissarissen. Daarnaast impliceert een nationaal korps verhoogde efficiëntie op het gebied van bestrijding van interregionale criminaliteit, het zonder meer beschikken over alle agenten waardoor versterkingen snel naar probleemgebieden gestuurd kunnen worden, en uniformiteit in het opsporings- en vervolgingsbeleid. Echter, Britten zijn over het algemeen geen voorstander van een nationale politie. ${ }^{278}$ Men vreest voor een politiestaat. ${ }^{279}$ Desondanks heeft de commissie in haar rapport uitgebreid deze materie behandeld. Het argument dat Engeland in een politiestaat zou veranderen is verworpen met de motivering dat, zolang de politie onder de wet staat en ter verantwoording geroepen kan worden, British liberty geen gevaar zal lopen. ${ }^{280}$ Wat dat betreft vormen de rule of law en de onafhankelijkheid van de rechterlijke macht voldoende walarborgen. Grondwettelijk zou een regeling van een nationale politie zelfs te prefereren zijn boven een systeem van lokale korpsen. De Home Secretary zou dan aansprakelijk zijn jegens het parlement voor activiteiten van de politie, zoals andere ministers op dit moment aansprakelijk zijn voor de openbare diensten waar zij voor verantwoordelijk zijn. De commissie toonde bovendien aan dat de ontwikkeling van het politiebestel tot op dat moment tendeerde naar een centraal georganiseerd instituut. Als er bezwaren zouden bestaan tegen een nationaal georganiseerd politieapparaat dan moesten er volgens de commissie andere argumenten aangedragen worden.

277. Royal Commission on the Police, 1962, p. 32

278. (Nederland trouwens ook niet.) Er bestat een sterke regionale gebondenheid en een sterk gevoel van trots. Alles wat van het buitenland komt is bij voorbaat al suspect. Daarnaast waren de Britten hun vrijheid gewend en kenden zij weinig state interference. Ze waren derhalve bevreesd voor een coup wan de politie. Bovendien zou de komst van een politie ook meer onkosten van overheidswege betekenen. Zie ook Taylor, 1970, p. 25-26.

279. Royal Commission on the Police, 1962, p. 45

280. Royal Commission on the Police, 1962, p. 45. 


\subsubsection{Never change a winning team}

Is het evenwel nodig het politieapparaat te nationaliseren? De commissie is uiteindelijk tot een negatief antwoord gekomen. Het systeem van lokale korpsen had het vertrouwen van de burgers. Bovendien werd in heel GrootBrittannië geaccepteerd dat centrale en lokale overheden samen enige vorm van besluitvorming hebben over publieke diensten. Aangezien in Engeland en Wales de handhaving van law and order een zaak van alle burgers is, lijkt een systeem van lokale korpsen en politiecommissies een voor de hand liggende zaak. Daarenboven toonden de problemen die aanleiding waren voor de instelling van de Royal Commission niet aan dat er in het systeem iets niet deugde. ${ }^{281}$ De commissie kwam derhalve tot de conclusie dat het systeem in grote lijnen kon blijven bestaan, maar dat het vraagstuk van de verantwoordelijkheid duidelijkheid nodig had.

Volgens de woorstellen van de commissie zou de bevelsketen op het niveau van de hoofdcommissaris moeten blijven eindigen. Niemand zou de bevoegdheid moeten hebben de hoofdcommissaris te bevelen, zelfs niet over brede beleidszaken. In deze situatie zou dus geen verandering komen vergeleken met de toen bestaande wetgeving. Wel zouden de hoofdcommissarissen voortaan verantwoording moeten afleggen aan de Police Aluthorities en aan de minister van het Home Office. De ministeriële verantwoordelijkheid over de efficiëntie van de politie zou daardoor vergroot worden, aangezien het parlement om rapporten zou kunnen vragen. Bovendien zou het aantal inspecteurs van het Home Office vermeerderd moeten worden, die daarnaast onder toezicht van een Chief Inspector zou komen te staan. Het lag overduidelijk in de bedoeling van de commissie om het centraal gezag meer bevoegdheden toe te kennen ten koste van het lokaal gezag dat bestond in de vorm van police authorities.

\subsubsection{Klachten}

Naast andere onderwerpen, heeft de commissie ook gekeken naar de klachtenprocedure. Elke klacht zou woortaan genoteerd moeten worden. ${ }^{282}$ De beslissing over de afdoening van elke klacht zou door de hoofdcommissaris of zijn deputy moeten geschieden. De normale gang van zaken zou moeten zijn dat een agent van een andere divisie het formele onderzoek naar de gegrondheid van een klacht uil zou moeten voeren. Indien er sprake zou zijn van een misdaad gepleegd door een agent, zou de Director of Public Prosecutions $^{283}$ ingeschakeld moeten worden. De commissie was van mening

281. Royal Commission on the Police, 1962, p. 47.

282. Royal Commission on the Police, 1962, aanbeveling 96 .

283. Het hoofd van het Britse Openbaar Ministerie. 
dat de toen heersende klachtenprocedure zoals die geregeld was in de Police (Discipline) Regulations, indien aangepast met de voorgestelde aanbevelingen, een zuiver en onpartijdig systeem met zich mee bracht. ${ }^{284}$ Het enige punt waarop fundamentele kritiek geleverd kan worden is het feit dat de politie binnen deze procedure haar eigen rechter is. Toch werd een extern, d. w.z. onafhankelijk van de politie, orgaan dat nagaat of de politie de klachten op een goede manier afhandelt door de meerderheid van de commissie overbodig geacht. De instelling van een dergelijk orgaan zou slecht kunnen zijn woor de moraal van het korps en daar zou het publiek helemaal niet mee gediend zijn. ${ }^{285}$ Wel stelde een minderheid, bestaande uit drie leden van de commissie, voor om een Commissioner of Rights ${ }^{286}$ in het leven te roepen die als taak zou krijgen klachten over de politie te onderzoeken.

\subsubsection{Memorandum of Dissent}

Eến lid van de commissie heeft het rapport niet ondertekend. A.L. Goodhart verschilde zo veel van mening met de rest van de commissie dat hij besloot in zijn dissent uiteen te zetten waarom hij van oordeel was dat Engeland en Wales gebaat zou zijn bij de vestiging van een national politiekorps. ${ }^{287}$

Goodhart constateerde dat wat loon, arbeidswoorwaarden en regels van orde betrof, er al centrale controle bestond. ${ }^{288}$ Een centraal georganiseerd en gecontroleerd politieapparaat zou in de praktijk niet tot veel veranderingen leiden. Het enige zichtbare zou zijn dat de titel van hoofdcommissaris zou verdwijnen. Alle lokale korpsen zouden gewoon blijven bestaan; enkel het beheer erover zou in andere handen komen. Een nationaal korps zou tot gevolg hebben dat de leiding van de plaatselijke korpsen aangesproken zouden kunnen worden voor hun handelen. Goodhart zag als een voordeel van een nationale politie een verhoging van de efficiëntie op het gebied van de bestrijding van interlokale misdaad en van samenwerking in de vorm van crime squads en verkeerscontrole. Ook in de geschiedenis van de politie vond hij geen argument om het bestaande systeem te handhaven. Het principe dat een constable niet onderworpen mocht zijn aan bevelen van hoger-

284. Royal Commission on the Police, 1962, p. 128-129.

285. Royal Commission on the Police, 1962, p. 136-138.

286. Dit voorstel was gebaseerd op een rapport, gepubliceerd door de organisatie JUSTICE van december 1961. Royal Commission on the Police, 1962, Appendix V, p. 193. De Commissioner of Rights zou, na de afhandeling van de klacht door de hoofdcommissaris, de dossierstukken kunnen opvragen om na te gaan of de zaak op een juiste wijze in ogenschouw is genomen.

287. Royal Commission on the Police, 1962, p. 157-181.

288. Goodhart, 1962, p. 177. 
hand was volgens hem onjuist en vond ook geen basis in de jurisprudentie. ${ }^{289} \mathrm{Zijn}$ de onafhankelijkheid van de hoofdcommissaris en het feit dat hij geen verantwoording hoeft af te leggen aan het parlement vereisten voor zijn onpartijdgheid in de uitoefening van zijn taak? Goodhart trok dit sterk in twijfel. 290

\section{6 'Every country in the world envies us our police' ${ }^{291}$}

In 1963 werd het rapport van de commissie, in het kader van voorstellen van de regering voor een ontwerp van een politiewet, in het Engelse House of Commons besproken. ${ }^{292}$ Enkele aambevelingen zijn vrijwel direct door de regering overgenomen, zoals het uitbreiden van de inspecteurs en de benoeming van een hoofdinspecteur van het Inspectorate van het Home Office. Andere aanbevelingen zouden, na consultatie van het parlement, geheel of gedeeltelijk door middel van wetgeving ingevoerd worden. In mei 1963 maakte derhalwe minister Mr. Henry Brooke de plannen van de regering bekend aangaande het rapport. Bij de bespreking van het rapport is hij uitvoerig ingegaan op de aanbevelingen van de commissie.

De commissie had voorgesteld dat de minister verantwoording zou moeten dragen voor de efficiëntie van de politie. Minister Brooke verschilde hier van mening met de commissie. Hij was van oordeel dat hij geen verantwoording zou hoeven te dragen over zaken waarover hij geen macht of zeggenschap had. ${ }^{293}$ Voor zaken waarin hij wel enig besluit nam, was hij ten wolle verantwoordelijk. Te denken valt hierbij aan het vragen om een rapport van een hoofdcommissaris. Dit feit zou tot gevolg hebben dat het parlement meer dan vroeger informatie over het functioneren van de politie zou ontwangen zonder dat de hoofdcommissarissen telkens door het parlement en de regering op de vingers gekeken zouden worden. Desondanks heerste er onvrede in het House of Commons dat hoofdcommissarissen voor het politieoptreden niet aansprakelijk konden worden gesteld. ${ }^{294}$

289. Goodhari, 1962, p. 160-161.

290. Goodhart, 1962, p. 163.

291. Mr Brooke (Home Secretary), 9 May 1963, 677, H. C. Deb., 5th Ser, kolom 698.

292. 677. H.C. Deb., 5th Ser., kolommen 680-799.

293. "A Minister ought not to have responsibility without power.' 677 H.C. Deb., 5th Ser., kolom 689; Zie ook Whitaker, 1979, p. 182.

294. 677 H.C. Deb., 5th Ser., kolommen 689-690. 


\subsubsection{Het parlement}

Het rapport van de commissie is op 9 mei 1963 besproken door het House of Commons. Gedurende de gehele bespreking kwamen telkens weer dezelfde kritiekpunten zowel op het rapport als op de ideeën van de minister naar voren. Over het algemeen betreurde men het in het parlement dat er weinig aandacht aan de relatie publiek-politie werd geschonken, aangezien dit immers als reden aangegeven was woor de instelling wan een Royal Commission. ${ }^{295}$ Volgens Fletcher, lid van de kamer, was de verhouding tussen politie en publiek - in tegenstelling tot hetgeen de commissie had beweerd wel degelijk verstoord. ${ }^{296}$ Bovendien werd het als een handicap ervaren dat de politie lokaal was georganiseerd, terwijl de misdaad zich niet aan de lokale grenzen laat binden. ${ }^{297}$ In het parlement waren dus wel voorstanders te vinden van een nationaal georganiseerd politiekorps. ${ }^{298}$ Voornamelijk bestond de klacht in het parlement dat er wel over de Metropolitan Police in Londen, maar niet over de politie in andere delen van het land vragen konden worden gesteld. Met name het feit dat de hoofdcommissaris 'is accountable to no one" 299 stoorde enkele leden wan het parlement erg. ${ }^{300} M r$. Shepherd, lid van het Lagerhuis, zei hierover: "We must get the police to agree that some form of democratic control is not irksome or damaging to their prestige. ${ }^{301}$ Wat hier ook meespeelde was dat de lokale overheid - watch committee - eveneens geen mogelijkheid bezat tot effectieve controle. Ondanks dit gegeven had de commissie geopteerd voor het in stand houden van het bestaande systeem. ${ }^{302}$

295. 677, H.C. Deb, 5th Ser., kolom 706-710 (Mr. Fletcher).

296. Ook Mr. Greenwood, lid van het House of Commons, gaf tijdens het debat aan dat vooral de verhouding politie-gekleurde burgers verslechterd is. De commissie had aan deze relatie in het geheel geen aandacht geschonken. $677 \mathrm{H}$.C. Deb., Sth Ser, kolommen 722-723; Mr. Shepherd dacht dat de oorzak te vinden was in het feit dat de samenleving in het algemeen zo weinig van de politie afweet. 677 H.C. Deb., 5th Ser., kolom 735.

297. 677 H.C. Deb., 5th Ser., kolom 700 (Mr. Eric Fletcher).

298. O.a. Mr. Iremonger en $M r$. Ph. Goodhart. Natuurlijk ook tegenstanders, waaronder Mr. Jones en Mr. Bingham. 677 H.C. Deb., Sth Ser., kolom 744,747.

299. Royal Commission on the Police, 1962, p. 31.

300. 677 H.C. Deb., 5th Ser., kolom 704 (Mr. Fletcher), kolom 716 (Mr. Renton), kolom 733 ( $M r$. Williams), kolom $756-757$ (Mr. Pannell), kolom 779 ( $M r$. lremonger).

301. 677 H.C. Deb., Sth., kolom 736.

302. Mr. Iremonger maakte tijdens het debat de opmerking dat het geen sterk argument is om vast te houden aan de traditie van de gegroeide relatie tussen hoofdcommissarissen en lokaal bestuur. Immers, met het voorstel van de com- 
De Home Secretary was eveneens geen woorstander van een nationaal korps. Hij had in het parlement aangegeven dat hij geen verantwoording wenste zonder de mogelijkheid te hebben om beslissingen te nemen. De commissie en hij wilden niet aan de onafhankelijkheid van de hoofdcommissaris komen. De macht van de hoofdcommissaris om baas over zijn eigen korps te zijn wilde de minister sespecteren. Brooke weigerde derhalve tegenover het parlement verantwoordelijk te zijn voor de politie. Deze situatie van verantwoording zonder macht bestond wel voor de stad Londen. "He cannot tell the Commissioner how to run the police, yet he must answer questions and debates in this House about what they do or fail to do.' Tegen deze situatie had de Home Secretary echter nooit bezwaar gemaakt. ${ }^{303}$ Het dragen van verantwoording zonder de macht te hebben komt vaker voor en is in Engeland niet echt uitzonderlijk. "Under our constitution we are accustomed to ministers having responsibility without power. ${ }^{304}$ Derhalve wensten leden in het parlement dat de Home Secretary een bepaalde vorm van verantwoordelijkheid zou moeten dragen om ervoor zorg te dragen dat de politie op een efficiènte wijze zou werken. ${ }^{305}$

Een ander aandachtspunt van het parlement was de klachtenprocedure. Hierover werd in het House of Commons gesproken in het licht van de aansprakelijkheid van de politie. De procedure werd afgedaan als vaag en duister. Voorstellen van de commissie brachten niet veel verandering in de situatie. Men wenste een tribunaal, een (openbare) zitting in rechtbanken of een Commissioner of Rights, zoals voorgesteld door een minderheid van de commissie (een gevolg van de gebeurtenis in Thurso). ${ }^{306}$ De Joint UnderSecretary of State Mr. Woodhouse zei op het einde van het debat dat hij hier niet aan wilde beginnen, aangezien de interventie van een extern lichaam slecht zou zijn voor de moraal van het politiekorps en derhalve slecht zou zijn voor het algemeen belang. ${ }^{307}$ Daarmee beschermde hij de autonomie van de politie.

302. $\rightarrow$

missie, dat zeer waarschijnlijk overgenomen zou worden door de regering, om politiekorpsen drastisch samen te voegen, zouden sowieso veel wan dic verhoudingen verdwijnen. Dan zou je evengoed direct over kunnen gaan op een centraal georganiseerde politie. 677 H.C. Deb., 5th Ser., kolom 779.

303. 677, H.C. Deb., 5th Ser., kolom 716.

304. Zoals het geval is bij de nationale industrieën en de BBC. Zie 677 H.C. Deb., 5th Ser., kolom 716 .

305. Zie bijwoorbeeld $M r$. F. Soskice, 677 H. C. Deb. sth Ser., 784-785.

306. 677 H.C. Deb., 5th Ser., kolommen $738,752,759,778,786$.

307. 677 H.C. Deb., 5th Ser., kolom 798. 


\subsection{Het wetsontwerp}

In november 1963 werd door de regering een ontwerp ingediend voor een nieuwe politiewet. Voor het eerst in de geschiedenis van de politie omvatte het voorstel een omschrijving van de functies van de minister van het Home Office, de politiecommissies en de hoofdcommissaris. Het wetsontwerp sloot naw aan bij de aanbevelingen van de Royal Commission. Zonder veel moeilijkheden is het wetsontwerp door het parlement gekomen. In juni 1964 ontving het ontwerp de koninklijke goedkeuring. Op 1 juni 1965 is de Police Act 1964 van kracht geworden.

\subsection{Police Act 1964}

In deze paragraaf wil ik tenslotte in het kort ingaan op de voomaamste wijzigingen van de Engelse politiewet. ${ }^{30}$ De belangrijkste conclusie die uit de wet getrokken kan worden is, zoals al eerder opgemerkt, de werschuiving van lokale naar centrale controle. Ook het parlement heeft in de wet enkele rechten gekregen om informatie aan de minister te vragen betreffende politiezaken.

\subsubsection{Minister}

De Police Act 1964 versterkte de bevoegdheden van de centrale overheid. Het Home Office kreeg de bevoegdheid om rapporten te vragen van de hoofdcommissaris. De minister kon en kan zijn veto uitspreken over de benoeming van hogere officieren; hij heeft de plicht om inefficiënte hoofdcommissarissen te dwingen ontslag te nemen. Daarnaast kan hij nog een onderzoek instellen naar het politieoptreden in elk lokaal politiegebied. De minister kreeg de verantwoordelijkheid om zorg te dragen voor een nationaal verbeterde politie-efficiëntie. De Police Act 1964 had o.a. tot gevolg dat de bureaucratie toenam. De afdelingen op het ministerie die zich bezig hielden met politiezaken namen aanzienlijk toe. ${ }^{309}$

Men krijgt door deze ontwikkelingen het idee dat de politie onderworpen wordt aan verborgen controle door de overheid, terwijl de politie in feite in het openbaar geen verantwoording hoeft af te leggen. Vooral het middel van de financiele toelage is een machtig instrument in de handen van de centrale regering. ${ }^{310}$ Over manschappen en een efficiënt politieoptreden heeft de

308. Deze wet is laatstelijk gewijzigd met de invoering van de Police and Magistraies' Court Act 1994. Waar nodig geef ik aan waar de nieuwe regeling van de oude verschilt

309. Brogden, 1982, p. 107.

310. Lustgarten, 1986, p. 102. 
overheid het laatste woord. Brogden beweert echter dat van (indirecte) controle in het geheel geen sprake was. De feitelijke controle van de overheid over de politie nam niet toe. In de periode na 1964 heeft de politiemacht - op twee periodes na in 1968/69 en 1973/74 - in omvang kunnen toenemen. ${ }^{311}$ Ambtenaren van de centrale overheid hebben op dit punt hun eigen relatieve onmacht erkend tegenover het zelfbeschikkingsrecht van de hoofdcommissarissen. De hoofdcommissarissen zijn bij uitstek de deskundigen om de efficiëntie en het personeelsbeleid woor hun eigen korpsen na te gaan. De politiek komt dan ook vaak bij de hoofccommissaris terecht wanneer het de vraag betreft of het voor het politiebeleid noodzakelijk is dat het korps uitbreiding behoeft.

\subsubsection{Parlement}

Vanwege art. 28 Police Act 1964 worden parlementsleden, meer dan in het verleden, in staat gesteld aan de minister vragen te stellen over politiezaken. Dit geldt niet alleen voor vragen over de Metropolitan Police. Parlementsleden kunnen de minister vragen (a) of hij van plan is een rapport op te vragen van een hoofdcommissaris (b) of hij aan de politiecommissie zal verzoeken de hoofdcommissaris te ontslaan en (c) of hij van zijn macht gebruik zal maken om de financiële toelage ( $g r a n t$ ) in te houden of een lokaal onderzoek in te stellen.

ad a) Het voorgaande houdt in dat de minister bevoegd is om een rapport op te vragen van de hoofdcommissaris (art. 30). Deze bevoegdheid gaat verder dan de bevoegdheid die een politiecommissie bezit. In dit geval mag de hoofdcommissaris ook niet weigeren een rapport op te stellen. De minister is niet verplicht de inhoud van het rapport mee te delen aan de politiecommissie.

De minister kan ook een lokaal onderzoek gelasten door een speciaal door hem daarvoor benoemd persoon naar een mogelijk inefficiënt politieoptreden of naar klachten tegen de politie. Zo'n onderzoek kan zowel openbaar of gesloten zijn. Als de resultaten van een dergelijk onderzoek niet gepubliceerd worden, dan moet de minister een samenvatting van de resultaten geven indien dit niet in strijd is met het openbaar belang.

ad b) De bevoegdheid van de minister om de politiecommissies te verzoeken een hoofdcommissaris te ontslaan wordt geregeld in art. 29 van de Engelse Politiewet. De hoofdcommissaris wordt wel in de gelegenheid gesteld ten behoeve van zichzelf representations te maken. De sancties op het niet ingaan op dit verzoek van de minis-

311. Brogden, 1982, p. 107. 
ter zijn het intrekken van de financiële toelage en een bevelschrift van het hooggerechtshof (mandamus).

ad c) De minister draagt bij in de kosten van het politiebestel. Tot apri] 1995 bedroeg de toelage zo'n $51 \%{ }^{312}$. Sinds de Police and Magistrates' Courts Act 1994 worden aan de uitgaven van de politiecommissies grenzen gesteld. De minister bepaalt via een rekenkundige formule het bedrag dat elk politiekorps afzonderlijk krijgt. ${ }^{3 / 3}$ Op deze wijze hoopt de overheid politieke beïnvloeding van de politiecommissies te beperken. Aan de andere kant heeft de minister zo een machtsinstrument in handen gekregen, waarmee hij de hoofdcommissarissen kan dwingen een bepaald (politiek) beleid uit te stippelen. Door middel van inspecteurs wordt nagegaan of politiekorpsen efficiënt te werk gaan. ${ }^{314}$ De politiekorpsen zijn feitelijk afhankelijk van de financiële toelage van de minister. Sinds 1964 zijn er geen situaties geweest die aanleiding hebben gegeven tot het inhouden wan de toelage. ${ }^{315}$

\section{8 .3 Klachten}

In artikel 49 van de Police ACt 1964 was aangegeven hoe klachten genoteerd en afgehandeld moesten worden. Elke klacht zou verplicht opgenomen en serieus onderzocht moeten worden. De hoofdcommissaris zelf mag de zaak onderzoeken. De Home Secretary kan echter aangeven dat de hoofdcommissaris de zaak moet laten onderzoeken door een agent van een ander politiekorps. Als (en alleen als) uit het onderzoek blijkt dat er sprake is van een strafbaar feit, moet het dossier overhandigd worden aan de DPP.

\subsection{Conclusie}

De Police Act 1964 heeft geen oplossing geboden voor de slechte verhouding tussen politie en burger. De Royal Commission on the Police kwam zelfs in haar rapport tot de conclusie dat er van een slechte verhouding in het geheel geen sprake was. Het is natuurlijk achteraf moeilijk te beoordelen of dat daadwerkelijk zo is geweest. Daarwoor zouden onder andere de gehanteerde onderzoeksvragen bekeken moeten worden. Gezien de gedane

312. Bond, 1988, p. 300; Bell, 1989, p. 60.

313. Berry, Izat, Mawby, Walley, 1995 , p. 60.

314. "The primary function of the Inspector is to advise the Home Secretary whether the forces were maintained efficiently so that they qualified for the Exchequer Grant." Lord Horsham van het Home Office in 1958; zie Brogden, 1982, p. 112.

315. Oliver, 1987 , p. 103. Al schijnt Derbyshire laatst in problemen te zijn geraakt. Derbyshire kreeg tot drie keer toe geen certicifate of efficiency. Zie Berry, Izat, Mawby en Walley, 1995, p. 60. 
aanbevelingen was men ontevreden over de positie van de politie in de maatschappij. Naar mijn mening geeft dit aan dat men duidelijkheid wilde over de bevoegdheden van de politie. De vraag naar meer duidelijkheid komt alleen naar voren als maatschappij en/of media niet tevreden zijn over de positie van de politie. In zekere zin kun je volgens mij dan niet spreken van een goede verhouding tussen burgers en politie.

De Police Act 1964 heeft slechts omschreven wat de rechten en plichten zijn van de minister, politiecommissies en hoofdcommissarissen aangaande politiezaken. Ook is er meer aandacht voor een klachtenprocedure gekomen, hetgeen ten goede zou kunnen komen aan de verhouding tussen politie en burgers. De klachtenprocedure echter is lange tijd onderwerp van discussie in het parlement geweest zoals we in het volgende hoofdstuk zullen zien. 


\section{Klachten over politieoptreden: de dood van Blair Peach}

\subsection{Inleiding}

De redenen van mensen om een klacht in te dienen over politieoptreden variëren nogall. Ze zijn van mening dat de beschuldigde agent gestraft moet worden of willen herhaling van het wangedrag van de politie voorkomen. Andere mensen menen recht te hebben op een financiële vergoeding of willen graag een uitleg over het gebeurde ontvangen en daarbij een verontschuldiging krijgen. In sommige gevallen willen mensen gewoon hun onvrede en ergernis uiten. Sporadisch komt het voor dat het indienen van een klacht geschiedt als reden voor een verder gelegen doel, bijwoorbeeld om een aanklacht te voorkomen. ${ }^{316}$

Het doel van een klachtenprocedure is de burger een middel te geven om te reageren op het 'ongewenst' optreden van politieagenten. Tijdens een dergelijke procedure wordt bekeken of de klacht gegrond is en welke strafrechtelijke of disciplinaire sanctie genomen zou moeten worden.

\subsection{De procedure in de Police Acts van 1964 en 1976}

In de Police Act 1964 was in art. 49 opgenomen hoe een hoofdcommissaris klachten van burgers over (het optreden van) politieagenten moest behandelen. De clausule bevatte de bepaling dat een hoofdcommissaris verplicht was een klacht te noteren en te onderzoeken. Over een dergelijke afhandeling van klachten was men in het algemeen echter niet tevreden. ${ }^{317}$ Hetgeen ontbrak was een onafhankelijk element in de procedure. ${ }^{318}$ Al vanaf 1965 werden er in het House of Commons regelmatig vragen gesteld over het aantal klachten tegen de politie in de hoofdstad ${ }^{319}$ en over de wenselijkheid van onafhankelijk toezicht op de procedure. Zo nu en dan kwam een incident in het Huis aan de orde, waarbij de politie verdacht werd een burger mishandeld te hebben of misbruik te hebben gemaakt van haar wettelijke

316. Brown, 1987, p. 12-13

317. 787, H.C. Deb., Sth Ser., 2107-2108 kolommen; 805, H.C. Deb., Sth Ser., written answers, kolom $172 ; 853$, H.C. Deb., 5th Ser, written answers, kolom 133.

318. Clayton en Tomlinson, 1987, p. 10.

319. In de jaren ' 60 vond er in Engeland en Wales een toename wan de jeugd toe, vanwege de baby-boom na de Tweede Wereldoorlog. Dit was er ook de oorzaak van dat de politie vaker in conflict met jongeren kwam en dat er meer geklatgd werd. 
bevoegdheden. ${ }^{320}$ In februari $1973^{321}$ kondigde de minister van het Home Office eindelijk an diat naar de klachtenprocedure gekeken zou worden. Een jaar later lag er voor het parlement een rapport van een werkgroep klaar. ${ }^{322}$ In het rapport konden de leden van de werkgroep niet tot een eensiluidende conclusie komen ${ }^{323}$ Eind juli bood de Labour-regering in de persoon van Home Secretary Roy Jenkins het parlement een voorstel aan in de vorm van een outline scheme teneinde de klachtenprocedure te wijzigen. ${ }^{324}$ In dit voorstel zou een onafhankelijke commissie de mogelijkheid krijgen de afhandeling van een klacht te onderzoeken. Voordat de minister een wetsontwerp met deze inhoud zou indienen, wilde hij eerst de mening over het voorstel vernemen wan politie en politiecommissies. Het parlement liet de minister niet met rust. Maandelijks werd aan de minister gevraagd wanneer hij nu eindelijk een wetsontwerp zou indienen. ${ }^{325}$ Op 15 juli 1975 was het zover. ${ }^{326}$ Op die dag had $M r$. Roy Jenkins een voorstel klaar liggen dat later dat jaar in een wetsontwerp vervat zou worden. Het voorstel hield in dat een onafhankelijke commissie - een Police Complaints Board -, benoemd door de Home Secretary, ingeschakeld zou worden bij de klachtenprocedure. Verder zou uit de Board een tribunal gevormd kunnen worden, dat in bijzondere gevallen over de gegrondheid van de klacht zou moeten besluiten. Van die gevallen zou sprake zijn indien de (deputy) hoofdcommissaris van oordeel was dat een disciplinaire maatregel op zijn plaats zou zijn, maar de agent het feit of de gebeurtenis zou ontkennen. De Police Act 1976 kreeg op 6 augustus 1976 de Royal Assent. In deze wetgeving werd voortaan een onafhankelijke instantie in de procedure geschapen: de meeste ${ }^{327} \mathrm{klach}$ -

320. 777, H.C. Deb., 5th Ser., written answers, kolommen 368-369; 854, H.C. Deb., 5th Ser., kolom 1472; 867, H.C. Deb., Sth Ser., kolom 1868; 881, H.C. Deb., 5th Ser., kolommen 268-269; 882, H.C. Deb., 5th Ser., written answers, kolom 60; 886, H.C. Deb., Sth Ser, written answers, kolommen 417-418.

321. Dit werd bevestigd tijdens het debat over het onderzoek naar klachten bij de Metropolitan Police. 854, H.C. Deb., 5th Ser., kolom 1474.

322. Op 28 maart 1974; Working Group for England and Wales, The handling of complaints against the police; 871 , H.C. Deb., 5th Ser, written answers, kolom 204.

323. Report of the Working Group for England and Wales, 1974, p. 36-37.

324. 878, H.C. Deb., 5th Ser., kollommen 144-146.

325. Bijv. 881, H. C. Deb., 5th Ser., written answers, kolom 465; 882, H.C. Deb., 5th Ser., written answers, kolom 60;887, H.C. Deb., 5th Ser., kolommen 1754-1755; 889, H.C. Deb., Sth Ser, written answers, kollom 440; 892, H.C. Deb., 5th Ser., written answers, kolom 198.

326. 895, H.C. Deb., 5th Ser., written answers, kolommen 423-428.

327. Als de chief officer van mening was dat een strafbaar feit was gepleegd, stuurde hij de klacht door naar de Director of Public Prosecutions en naar de Police 
ten werden verwezen naar een onafhankelijke Police Complaints Board, die bevoegd was na te gaan of een disciplinaire aanklacht op zijn plaats was. ${ }^{328}$ De Police Complaints Board kon de (deputy) hoofdcommissaris aanbevelen over te gaan tot het nemen van een disciplinaire aanklacht. Wanneer de (deputy) hoofdcommissaris daartoe niet overging, had de Board de bevoegdheid hem daartoe te bevelen. De woorzitter en al de andere leden van de Police Complaints Board werden benoemd door de Prime Minister. Het aantal leden was beperkt en nooit meer dan negen.

\section{3 'Is not the fact that police investigate police an inherent weakness in the scheme? ${ }^{329}$}

Desondanks bleef kritiek bestaan. ${ }^{330}$ Problematisch werd gevonden dat de politie uiteindelijk gewoon zich zelf onderzocht en dat de Police Complaints Board over onvoldoende mogelijkheden beschikte om het door de politie verrichte onderzoek te toetsen of uit te breiden. ${ }^{331}$ Bovendien werd het als een tekortkoming in het systeem gezien dat zowel de Director of Public Prosecutions als de Police Complaints Board niet konden onderzoeken op welke wijze de klacht in eerste instantie door de politie werd afgehandeld. Alleen wanneer de (deputy) hoofdcommissaris er niet van overtuigd was dat er geen strafbaar feit door zijn agent(-en) was gepleegd werd het rapport namelijk doorgestuurd naar de DPP of de Police Complaints Board, in het andere geval niet.

Rond de jaren tachtig waren er veel botsingen tussen de politie en de burgers. Er waren voornamelijk veel jongeren met nieuwe normen. In 1979 overleed een tweetal personen, Blair Peach en Jimmy Kelly tengevolge van vermeend verkeerd politieoptreden. Naar de dood van Peach werd een onderzoek gedaan door een inofficiële onderzoekscommissie. ${ }^{332}$

327. $\rightarrow$

Complaims Board. De Police Complaints Board had derhalve geen inzage in de rapporten waarbij het politieonderzoek had 'aangetoond' dat er geen sprake was van een strafbaar feit.

328. Zie Police Act 1976, artt. 2, 3 en 5; Trouwens, de commissioner van London, Sir Robert Mark trad vroegtijdig af als hoofdcommissaris uit protest tegen de komst van de Police Complaints Board. Reiner, 1994, p. 747.

329. 985, H.C. Deb., 5th Ser., kolom 1659 (Mr. Dormand).

330. Bijw. 973, H.C. Deb., 5th Ser, kolommen 1479-1483.

331. 985, H.C. Deb., 5th Ser., kolommen 1659-1660; 987, H.C. Deb., 5th Ser. kolommen 1740-1742; Reiner, 1994, p. 747.

332. Unofficial Committee of Enquiry, onder voorzitterschap van Michael Dummett. 


\subsubsection{Blair Peach}

Tijdens de landelijke algemene verkiezingscampagnes in Engeland in april 1979, hield de National Front-partij ${ }^{333}$ een verkiezingsbijeenkomst in Southall $^{334}$. Tegenstanders van deze partij wilden demonstraties organiseren. Dit was door de politie verboden, waarschijnlijk vanwege het gevar van rellen. Desondanks verzamelde zich een groot aantal mensen in Southall om te protesteren tegen de National Front. Blair Peach, een 33-jarige onderwijzer, was één wan hen. Omdat de politie het gebied afgezet had, kon de massa niet bij de verkiezingsbijeenkomst komen. Toen de politie het terrein na afloop van de bijeenkomst vrijgaf, waren veel demonstranten al naar huis vertrokken of gingen weg. De 'demonstratie' was tot op dat moment vreedzaam verlopen. ${ }^{335}$

Waarschijnlijk zonder enige aanleiding werd plotseling een brandbom in de richting van een politiebus gegooil. Als reactie kwam de politiebus met een langzame, - doch gezien de drukte een te hoge - snelheid op de menigte inrijden met als doel de menigte te verspreiden. De menigte reageerde verontwaardigd en kwaad op de politie die zo gevaarlijk een autobus in een menigte reed. Een inspecteur omschreef het aldus: 'There was a potential riot at that stage. The SPG (Special Patrol Group, cr, vergelijkbaar met de Mobiele Eenheid)) did cause hostility. ${ }^{336}$ Toen agenten enkele demonstranten achtervolgden, werd Blair Peach waarschijnlijk met een wapenstok door een agent van de Special Patrol Group op zijn hoofd gesiagen. ${ }^{337}$ Hij overleed enige tijd later. ${ }^{338}$ Commander Cass kreeg de opdracht de klacht te

333. Een extreem-rechtse politieke groepering.

334. Een buitenwijk van Londen, waar veel immigranten wonen met een Indiase of Pakistaanse achtergrond.

335. Unofficial Committee of Enquiry, 1980, p. 10.

336. Unofficial Committee of Enquiry, 1980, p. 11.

337. Volgens professor Bowen van Charing Cross Hospital, die een lijkschouwing. had verricht. was het meest waarschijnlijke wapen dat gebruikt had kunnen worden een "police radio - which measures 7 "by $3^{\text {" by }} 11 / 2$ " and weighs over 500 grams', terwijl alle getuigen hadden gesproken van een truncheon. Geen enkele agent gaf toe Blair Peach te hebben geslagen. Voor het Unofficial Committee of Inquiry reden am te schrijven: "the ewidence of none of the policemen present at the time is compatible with his having struck that blow. It is therefore certain that the evidence of at least one police witness is untrustworthy. "Unoffcial Committee of Enquiry, 1980, p. 14-15, 30, 32.

338. Blair Peach had een dumere schedel dan de meeste andere mensen. 'Professor

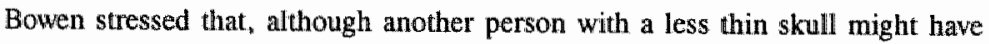
survived the blow, he would certainly have suffered head injury.' Unofficial Committee of Enquiry, 1980 , p. $20,32$. 
onderzoeken dat Peach overleden zou zijn naar aanleiding van een slag op het hoofd door een agent. ${ }^{339}$ Het rapport van Cass werd verzonden naar de Director of Public Prosecutions, die verder over de zaak zou beslissen. De DPP weigerde een vervolging in te stellen. ${ }^{340}$ Het rapport van Commander Cass is nooit openbaar gemaakt.

\subsubsection{Het Lagerhuis}

In thet House of Commons werden naar aanleiding van de dood van Peach vragen gesteld over een onafhankelijk onderzoek naar klachten over de politie. ${ }^{341}$ In het Huis werd eveneens een aantal van 60 personen genoemd dat in de afgelopen negen jaar in een politiecel was overleden. Dit aantal werd schrikbarend hoog gevonden. Het aantal klachten over mishandeling tegen de politie was in de periode 1970-1979 gestegen van ruim 1.000 tot over de $2.500{ }^{342}$ Home Secretary Whitelaw verzekerde het Huis echter dat de Police Complaints Board voldoende onafhankelijk was. Hij hield het Huis zelfs voor dat de parlementsleden de Board ingesteld hadden als een onafhankelijk onderzoeksorgaan en dat het Huis daarom niet langer over dit punt moest zeuren. ${ }^{343}$ Whitelaw wilde pas verbeteringen overwegen als hij het driejaarlijks verslag van de Board gezien had en dat verslag daar aanlleiding toe gaf ${ }^{344}$

In het driejaarlijkse rapport van de Police Complaints Board, dat op 15 juli 1980 gepubliceerd werd, werd als belangrijkste aanbeveling gegeven dat klachten welke een ernstige verwonding betreffen onderzocht zouden moeten worden door een specialist body of investigating officers. ${ }^{345}$ Een op te richten werkgroep onder leiding van Lord Plowden, voorzitter van de Police

339. Unofficial Committee of Enquiry, 1980, p. 33.

340. Er was wolgens de DPP te weinig zekerheid dat iemand veroordeeld zou worden. $D P P_{S}$ houden er over het algemeen rekening mee dat een jury niet gauw tot een bewezenverklaring komen als de werdachte een politieagent is. De $51 \%$ rule. Jefferson, 1990, p. 7; Unofficial Committee of Enquiry, 1980, p. 34.

341. 973, H.C. Deb., 5th Ser., kolommen 1479-1483.

342. 977, H.C. Deb., 5th Ser., written answers, kolom $321-322$.

343. Whitelaw verwees hier naar het feit dat de Labour-regering de Police Complaints Board ingesteld had en dat de meeste vragen over het niet onaflankelijk zijn van die Board juist wan de linkse wleugel van de Labour-partij kwan. 973 , H.C. Deb., 5th Ser., kolom 1481; 987, H.C. Deb., 5th Ser., kolom 1741.

344. 973, H.C. Deb., 5th Ser., kolom 1480.

345. 988, H.C. Deb., 5th Ser., written answers. kolommen 488-489. 
Complaints Board, zou nagaian hoe deze aanbeveling in het bestaande systeem verwerkt zou kunnen worden. ${ }^{346}$

\subsubsection{Het Scarman-rappont}

Ook buiten het parlement werd er commentaar gegeven op het klachtensysteem. Lord Scarman constateerde in zijn rapport naar aanleiding van de Brixton-rellen in 1981 een gebrek aan vertrouwen van het publiek in de onpartijdigheid en de eerlijkheid van de klachtenprocedure. ${ }^{347}$ Volgens Scarman zou het vertrouwen in de klachtenprocedure slechts toenemen, indien de procedure voor de afhandeling van klachten geheel onafhankelijk van de politie zou worden uitgevoerd. ${ }^{348}$ Scarman was van mening dat de regeling op grond van de Police Act 1976 de klager een onvoldaan gevoel gaf. De klager werd buiten de procedure gehouden. Het klachtensysteem had meer oog voor de politieagenten en de op te leggen disciplinaire maatregelen. Bovendien was de gehele procedure zeer formeel. Elke klacht, hoe onbeduidend ook, werd volledig aan een onderzoek onderworpen, tenzij de klager de klacht introk. Daarnaast bevatte het klachtensysteem grote waarborgen voor de beschuldigde agenten hetgeen de kans om de klacht met succes te bewijzen aanzienlijk verminderde. ${ }^{349}$ Scarman heeft in zijn rapport enkele voorstellen gedaan tot hervorming wan de klachtenprocedure:

a) het onderzoek naar klachten zou onafhankelijk moeten geschieden;

b) er zou een leek als toezichthouder aangesteld moeten worden bij het onderzoeksproces;

c) een poging zou ondernomen moeten worden om minder ernstige klachten via de informele weg van verzoening op te lossen, en

d) klachten die niet gericht zijn tegen individuele agenten zouden niet onder de klachtenprocedure moeten vallen. ${ }^{350}$

\subsubsection{Nieuwe wetgeving}

In 1983 werd door Home Secretary L. Brittan de Police and Criminal Evidence Bill geïntroduceerd warin voorstellen tot wijziging van de klachten-

346. De werkgroep kreeg als opdracht mee: "To consider how the recommendation in the first triennial report of the Police Complaints Board for an independent element in the investigation of serious complaints against the police might be implemented, and to make a report." 989, H.C. Deb., 5th Ser., written answers, kolom 789.

347. Scarman, 1981, p. 116.

348. Scarman, 1981 , p. 88.

349. Brown, 1987, p. 1.

350. Scarman, 1981, p. 117-120. 
procedure opgenomen waren. Enkele voorstellen van Scarman zijn overgenomen in de wijziging. Het wetsontwerp leidde in 1984 tot de Police and Criminal Evidence Act 1984 (PACE). De Police Complaints Board werd hierbij verwangen door de Police Complaints Authority. Het nieuwe systeem biedt de mogelijkheid tot verzoening en informele afdoening.

\subsection{De procedure}

Het indienen van een klacht volgens de PACE 1984 kan informeel geschieden. Het kan zowel op schriftelijke als op mondelinge wijze gebeuren. Iedereen kan een klacht indienen. Het is geen vereiste dat de klager ook slachtoffer van omstreden politieoptreden moet zijn. Het is zelfs mogelijk dat iemand anders dan de klager de klacht namens de klager indient. In dit geval moet de klager wel zijn schriftelijke goedkeuring hieraan gegeven hebben. ${ }^{351}$ Een klacht over het gedrag of optreden van een agent moet worden neergelegd bij de bevoegde autoriteit. Dit kan de hoofdcommissaris of de commissioner zijn. Zij staan bekend als chief officers of police ${ }^{352}$. Tegenwoordig zijn chief officers wettelijk verplicht klachten op te nemen. In het verleden heeft de politie wel eens een klacht geweigerd te noteren. Weigering is nu alleen mar mogelijk als de klacht gericht is tegen de manier van leidinggeven of tegen het beleid van de chief officer. Dergelijke kritiek moet immers gericht worden aan het adres van de politiecommissie. Een klacht wordt ook niet meer genoteerd als er al een strafrechtelijke of disciplinaire actie tegen de politie ondernomen is ${ }^{353}$

Is de klacht gericht tegen een agent die de rang van chief superintendent of hoger heeft, dan is de bevoegde autoriteit de Police Authority (politiecommissie). Indien de klacht ernstig van aard is, dan wordt zij verwezen naar het onafhankelijk orgaan: Police Complaints Authority. De bevoegdheden van deze instantie in vergelijking met de Police Complaints Board zijn toegenomen omdat de Police Complaints Authority nu een rol te vervallen heeft bij het onderzoeksproces. Een klager kan op elk moment zijn klacht intrekken. Vanaf dat moment bestaat er voor de politie geen verplichting meer de zaak te onderzoeken. De politie beschikt echter over de mogelijkheid om het onderzoek desondanks woort te zetten. ${ }^{354}$

351. Harrison. 1987, p. 26.

352. Dexe agenten behoren tot de Association of Chief Police Officers (ACPO).

353. Harrison, 1987, p. 26.

354. Harrison, 1987, p. 33. 


\subsubsection{Informele afdoening}

Sinds 1984 kunnen klachten op een informele wijze afgedaan worden. Met de instelling van de mogelijkheid tot informele afdoening van klachten is beoogd ernstige klachten op een flexibele wijze te scheiden van minder ernstige klachten. De klager moet toestemming geven voor een dergelijke afdoening (art. 85 lid 10 PACE 1984). Niet in alle gevallen is een informele afdoening mogelijk. Slechts in die gevallen dat de hoofdcommissaris ervan overtuigd is dat het wangedrag van de agent niet zou kunnen leiden tot een strafrechtelijke of disciplinaire vervolging, is informele afdoening toegestaan (art 85 lid 10 PACE 1984). Het afdoen zelf wordt of door de hoofdcommissaris of door een door hem daartoe benoemde agent gedaan. De agent tegen wie de klacht gericht is, moet erkennen dat zijn gedrag of handelen in die bepaalde situatie verkeerd was. Van de informele afdoening wordt een notitie gemaakt dije opgenomen wordt in een register. Dit register staat open voor inspectie door de politiecommissie en de inspecteurs van het Home Office. ${ }^{358}$

In de wet is over de methode van de informele afdoening niets omschreven. Informatie hierover is te vinden in de White Paper ${ }^{336}$ 'Police Complaints and Discipline Procedures' van $1983 .{ }^{357}$ Een vaste procedure bestaat niet, maar de Whire Paper geeft wel enige richtlijnen. In bepaalde gevallen zal een uitleg of verontschuldiging naar de klager toe voldoende zijn. In andere gevallen zal aan de klager meegedeeld worden dat met de betreffende agent gesproken zal worden. Het is ook mogelijk dat de klager uitgenodigd wordt voor een gesprek, al dan niet in aanwezigheid van de agent over wiens optreden geklaagd is. Voor een informele afdoening is het altijd vereist dat zowel klager alls agent in de gelegenheid worden gesteld commentaar te geven. ${ }^{358}$ De klager kan op zijn verzoek een kopie van het proces-verbaal krijgen. ${ }^{359}$ Van een informele afdoening wordt geen aantekening gemaakt in het persoonlijk dossier van de agent. Een klacht die informeel afgehandeld wordt, kan derhalve geen invloed uitoefenen op de verdere carrière van individuele agenten.

355. Zander, 1985 , p. 125 .

356. Een White Paper is een document van de overheid waarin bepaalde zaken nader uitgewerkt worden.

357. 1983, London, HMSO, Cmnd. 9072.

358. Zander, 1985, p. 125; White Paper, 1983, p. 10. para. 32.

359. Dit moet geschieden binnen drie maanden na het opnemen wan het proces-werbaal in het register. White Paper, 1983, p. 10, para. 32; Clayton en Tomlinson, 1987, p. 43-44. 


\section{4 .2 De standaard procedure}

Indien een klacht niet informeel afgedaan wordt, gelast de hoofdcommissaris een formeel onderzoek. Voor het onderzoek naar de gegrondheid van de klacht wijst de hoofdcommissaris een agent aan. ${ }^{360}$ De agent moet voor deze taak tenminste de rang vervullen wan chief inspector en mag bovendien niet werkzaam zijn in dezelfde subdivisie of afdeling als die van de agent waartegen de klacht ingediend is. Indien het onderzoek niet onder supervisie geschiedt van de Police Complainis Authority, moet de onderzoekende agent zijn bevindingen in een rapport aan de hoofdcommissaris overhandigen. Voor agenten boven de rang van chief superintendent geldt op grond van de Police and Criminal Evidence Act 1984 een iets afwijkende procedure. Klachten tegen agenten vanaf de rang van chief superintendent, worden afgehandeld door de politiecommissie. (art. 86 lid 1 jo art. 84 lid 4 PACE) De rest van de procedure is verder gelijk als die woor de andere agenten.

\subsubsection{Police Complaints Authority}

Zoals hierboven beschreven, worden niet alle klachten behandeld door een onafhankelijke instantie waronder bijwoorbeeld de Police Complaints Authority $(P C A)$ werstaan kan worden. Het ontbreken van een onafhankelijke instantie is lange tijd het kritiekpunt geweest op de klachtenprocedure. Deze onvrede over het systeem is mede de aanleiding geweest tot het instellen van een Royal Commission on the Police in 1960 en tot verscheidene veranderingen in de procedure in de loop der tijd. Zolang niet voor alle klachten geldi dat ze onafhankelijk onderzocht zullen worden, zal kritiek op de klachtenprocedure blijven bestaan. Het ligt derhalve voor de hand dat ook de huidige procedure geen lang leven beschoren zal blijven. Lord Scarman zei hierover: 'My own view is that if public confidence in the police complaints: procedure is to be achieved, any solution falling short of a system of independent investigation, awailable for all complaints (other than the frivolous) which are not withdrawn, is unlikely to be successful." 361 De Police Federation is deze mening ook toegedaan. ${ }^{362}$

Sinds 1984 geldt de $P C A$ als onafhankelijk element in de klachtenprocedure. In tegenstelling tot de Police Complaints Board krijgt de $P C A$ nu wel de door de politie gepleegde afhandeling van de klachten onder ogen. Daardoor bestaat de garantie dat er vanaf het indienen van een klacht door een burger toezicht van een onafhankelijk orgaan op de procedure bestaat. De Police

360. Deze agent kan deel uitmaken van zijn eigen korps of wan een ander politiekorps.

361. Scarman, Cmnd. 8427 (1981), para 7.21

362. 1981-1982 H.C. 98-I, para. 32. 
Complaints Authority bestat uit een voorzifter en tenminste acht andere leden. Twee wan deze leden zijn vice-voorzitter. De voorzitter wordt benoend door de Kroon en de andere leden door de minister. ${ }^{363}$ De PCA heeft een tweeledige taak. Ze houdt in de eerste plaats toezicht op onderzoeken die plaatsvinden naar de gegrondheid van de klachten. Het doel hiervan is het publiek gerust te stellen dat onderzoeken die verricht worden door de politie onpartijdig. effectief en diepgaand zullen zijn. Daamaast bekijkt de authority het rapport van elk verricht onderzoek om te beslissen of een disciplinaire actie op zijn plaats is. ${ }^{364} \mathrm{De} P C A$ is niet alleen de bevoegde instantie woor klachten gericht tegen agenten van de 43 politiekorpsen in Engeland en Wales, maar daarnaast ook voor enkele bijzondere diensten. In dit kader kunnen genoemd worden de British Transpont Police, Ministry of Defence Police, Port of Liverpool Police, Port of London Authority Folice en de UK Atomic Energy Authority Constabulary.

Niet alle klachten worden, zoals hierboven al gesteld is, doorgestuurd naar de PCA. In drie gevallen slechts krijgt de Police Complaints Authority de klachten onder ogen:

1) indien het een klacht betreft over mogelijk wangedrag dat de dood of een ernstige verwonding tot gevolg heeft;

2) wanneer het om klachten gaat die door de minister in regelingen nader zijn uitgewerkt en

3) wanneer de bevoegde autoriteit van oordeel is dat de klacht verwezen zou moeten worden. 365

De regelingen onder punt (2) zijn te vinden in de Police (Complaints) (Mandatory Referrals) Regulations. ${ }^{366}$ Hierin worden enkele klachten nader omschreven waarvan het verplicht gesteld is dat ze naar de $P C A$ verwezen worden. Het betreft klachten over gedrag (a) waarin sprake is van een optreden waarbij lichamelijk letsel is toegebracht, (b) waarbij een overtreding is begaan onder art. 1 van de Prevention of Corruption Act 1916 en (c)

363. Zie schedule 4 van de Police and Criminal Evidence Act 1984.

364. Annual Report of the Police Complaints Authority (1989), London. HMSO, 1990 , p. 8.

365. Freeman, 1985, p. 60 132. In de Silcott-zaak vond er geen verwijzing plaats naar de $P C A$, terwijl de zaak in feite toch ernstig was. Waarschijnlijk had ie. mand anders dan Silcott een klacht ingediend. Informatie afkomstig van G.R. Markham, Assistant Chief Constable, Essex Police, die deze zaak alls bevoegde autoriteit nader onderzocht heeft. Dit onderzock leidde tot de rechtszaak - de Sillcott-zaak - waar enkele agenten terechitstonden.

366. [1985] S.I. 1985 no. 673. 
waarbij het wangedrag een ernstig strafbaar feit (serious arrestable offence) oplevert. ${ }^{36 ?}$

\subsubsection{Toezicht van de $P C A$}

In 1989 ontving de Police Complaints Authority 11.156 klachten in een totaal van 5.283 zaken. In slechts $12.6 \%$ van de zaken werd enige actie in de vorm van disciplinaire of strafrechtelijke maatregel ondernomen. In 24 gevallen werd er strafrechtelijk vervolgd. Meestal werd volstaan met het geven van een waarschuwing of advies aan het adres van de agent tegen wie de klacht gericht werd. Van de 8.820 klachten waarin tegen agenten geen actie ondernomen werd, werd door de $P C A$ in de meeste gevallen geoordeeld dat het bewijsmateriaal onvoldoende was of dat de agent, wiens optreden tot de klacht had geleid niet te identificeren was. ${ }^{368}$

De Police Complaints Authority verricht geen zelfstandig onderzoek naar klachten, maar houdt de onderzoeken onder toezicht die door agenten worden verricht. Indien een onderzoek onder supervisie van de $P C A$ geschiedt, moet de $P C A$ goedkeuring verlenen aan de keuze van de agent die de klacht aan een onderzoek gaat onderwerpen (zie art. $89 P A C E$ ). De PCA kan ook richtlijnen geven aan de agent die het onderzoek verricht. Na afloop van het onderzoek wordt het rapport door de agent aan de $P C A$ gezonden. De hoofdcommissaris (of de politiecommissie, afhankelijk van de rang van de agent tegen wie de klacht is ingediend) ontvangt een kopie (art. 89 lid 6 $P A C E$ ). De $P C A$ stelt vervolgens naar aanleiding van het rapport een verklaring op waarin punten opgenomen worden, die onder de aandacht van de bevoegde autoriteit gebracht zouden moeten worden (art. 89 lid 7 jo lid 10 $P A C E$ ). Geen disciplinaire maatregelen of strafrechtelijke sancties kunnen genomen worden totdat de verklaring bij de bevoegde autoriteit ${ }^{369}$ afgegeven is. De Director of Public Prosecutions kan echter wel tot vervolging van de agent tegen wie de klacht gericht is overgaan indien zich exceptione-

367. Wat verstan moet worden onder een serious arrestable offence wordt gedefinieerd in art. 24 lid 1 PACE 1984. De volgende misdaden vallen daaronder:

- misdaden waarbij de straf door de wet is vastgesteld;

- misdaden waarop een gevangenisstraf staat van meer dan vijf jarar;

- overtreding van artikelen van de Official Secrets Acls 1911 en 1920, Sexual Offences Acl 1956 (artt. 14,22, 23). Theft Act 1968 (artt. 12.1 en 25.1). Public Bodies. Practices ACl 1889 (art. 1) en Prevention of Corruption ACt 1906 (art. 1);

- overtredingen waarvoor gearresteerd kan worden onder de Customs and Excise Management Act 1979. Zie art. 24 lid I en 2 PACE 1984.

368. Annual Report of the Police Complaints Authority 1989, p. 24-27.

369. I.e. de deputy of assistant chief constable. 
le omstandigheden woordoen, die het niet wenselijk maken te wachten op de verklaring van de $P C A .{ }^{370}$ De $P C A$ heeft de bevoegdheid te bevelen dat een zaak naar de Crown Prosecution Service wordt gestuurd. ${ }^{371}$

\section{4 .5 Strafrecht of een disciplinaire maatregel}

Wat geschiedt als een klacht gegrond wordt verklaard? Als het een klacht betreft die gericht is tegen een chief superintendent of een agent die nog hoger in rang is, en indien uit het rapport blijkt dat de klacht gegrond is, dan stuurt de politiecommissie een kopie van het rapport door naar de $D i$ rector of Public Prosecutions (DPP), tenzij de politiecommissie ervan overtuigd is dat er geen sprake is van een strafbaar feit. ${ }^{372}$ Bij agenten lager in rang dan de super intendent heeft de hoofdcommissaris de keuze tussen disciplinaire of strafrechtelijke maatregelen. Disciplinaire maatregelen kan de hoofdcommissaris zelf nemen. ${ }^{373}$ Een strafrechtelijke vervolging moet echter overgelaten worden aan het justitiële apparaat. In dat geval worden de rapporten doorgespeeld naar de DPP. De Director beslist of er vervolgd zal worden. De Director zal vaak alleen vervolgen als een veroordeling een kans heeft van meer dan $50 \%^{374}$ of als een veroordeling in het algemeen belang vereist is ${ }^{375}$. Over het algemeen is een jury van de Engeise rechtbank terughoudend in het veroordelen van agenten. Daarnaast zijn de bewijsmiddelen in klachtzaken vaak slechts getuigenissen van de klager en van de agent. Het bewijs dat op deze wijze verkregen wordt zal in veel gevallen op zich onvoldoende zijn voor een veroordeling. Dit verklaart waarom slechts een gering aantal klachten wordt vervolgd.

De PCA kan het gewenst vinden dat de klacht voor een tribunaal gebracht wordt. Een dergelijke hoorzitting bestaat uit een voorzitter (een hoofdcommissaris of een persoon benoemd door de commissioner van de Metropolitan Police) en twee leden van de $P C A$, die de zaak nog niet eerder onder ogen hebben gehad (art. 94 PACE). De klager moet in de gelegenheid gesteld worden de hoorzitting bij te wonen. Hij mag daarbij geen advocaat, maar

370. Art. 89 leden 12, 13 en 14 PACE 1984.

371. Artikel 92 PACE.

372. Art. 90 lid 1 PACE 1984.

373. De disciplinaire sancties die een hoofdcommissaris kan nemen zijn: ontslag, het vereiste dat betreffende agent het korps verlaat, verlaging in rang, loonswerlaging voor ten hoogste 12 maanden, boete, reprimande of een waarschuwing. Harrison, 1987, p. 56. Sir Robert Mark ontsloeg veel rechercheurs die van corruptie verdacht waren, maar hij gebruikte disciplinaire maatregelen om lange strafrechtelijke procedures te vermijden. Mark, 1978, p. 131 .

374. Dit staat bekend onder de term 'the $51 \%$ nule". Harrison, 1987, p. 60.

375. James, 1980, p. 171. 
wel een kennis of familielid meenemen. Is de klager tevens getuige in de zaak, dan mag hij pas na zijn getuigenis de zaak bijwonen. De aanklacht moet bewezen worden 'beyond reasonable doubt', hetgeen vergeleken met civiele procedures een strenge eis is ${ }^{376}$ De sanctie wordt opgelegd door de hoofdofficier, na overleg met de twee andere leden. ${ }^{377}$ De klager wordt niet op de hoogte gebracht van de uitkomst (sanctie) van de zaak als de agent disciplinair wordt gehoord. ${ }^{378}$ In die gevallen dat een agent disciplinair gehoord wordt of voor een tribunaal moet komen, heeft de $P C A$ geen mogelijkheid meer controle uit te oefenen op het verdere verloop van de procedure. De $P C A$ ervaart dit zelf als een grote handicap. De $P C A$ adviseert dan ook de procedure op dit punt te wijzigen. Indien de PCA op alle niveaus als onafhankelijk controleapparaat zou fungeren, dan zou, volgens de $P C A$, het publiek ook eerder het volle vertrouwen kunnen krijgen in de procedure. ${ }^{379}$

Een agent die strafrechtelijk veroordeeld of vrijgesproken is, kan niet tevens disciplinair tot de orde geroepen worden. Dit wordt de double jeopardyregel genoemd. ${ }^{380}$ Dit beginsel is te vinden in art. 104 PACE. De bepaling geldt echter niet als de disciplinaire aanklacht bestaat in het schuldig zijn aan een strafbaar feit. In art. 105 PACE wordt gesteld dat de Home Secretary een richtlijn zal uitgeven over de verhouding tussen strafrechtelijke en disciplinaire aanklachten. Eenzelfde regeling was ook te vinden in art. 3 lid 8 van de Police Act 1976. In de zaak R. v. Police Complaints Board, ex p. Madden and Rhone [1983] 1 W.L.R. 447, werd duidelijk dat de (toentertijd nog) Police Complaints Board niet gehouden was in overeenstemming met deze richtlijn, gebaseerd op dat artikel van de Police Act 1976, te handelen. ${ }^{381}$ De $P C B$ en de hoofdofficieren hadden zelf een plicht na te gaan of een disciplinaire actie op zijn plaats was. Dit uitgangspunt is inmiddels verwerkt in de herziene richtlijn voor hoofdofficieren. In de richtlijn wordt nader aangegeven wanneer een criminele en een disciplinaire vervolging elkaar niet uitsluiten ${ }^{382}$, en in welke gevallen strafrechtelijk niet, maar dis-

376. Sanders, 1994 , p. 808.

377. Clayton en Tomlinson, 1987, p. 49

378. Annual Report of the Police Complaints Authority 1989, p. 14.

379. Police Complaints Authority, 1991, p. 14-15.

380. Clayton en Tomlinson, 1987, p. 50.

381. Clayton en Tomlinson" 1987, p. 51; zie ook White Paper, 1983, p. 12; Benyon, 'The Policing Issues', in: Benyon ${ }_{4}$ 1984, p. 109

382. 'In considering whether ... (section $104(1)$ ) operates, close attention should be paid to the similarity in the elements of the criminal charge and the possible disciplinary charge. In some cases they may not be as similar as appears at first sight: the mental element of the criminal offence may be lacking in the discipli- 
ciplinair wel, opgetreden kan worden. Als de DPP van mening is dat strafrechtelijk niet verwolgd moet worden, zal individueel bekeken moeten worden of en wat er disciplinair moet gebeuren. Een probleem kan hierbij optredien alls de strafrechtelijke overtreding nagenoeg gelijk (-luidend) is aan de disciplinaire overtreding. De disciplinaire autoriteiten worden op dit punt geheel vrijgelaten door de richtlijn. Zij zijn niet gebonden aan de beslissing van de $D P P$ om niet tot vervolging over te gaan, maar zij beslissen zelf wat in dat geval zal gebeuren." ${ }^{383}$

\subsubsection{Aanpassing van het systeem?}

In het driejaarlijkse rapport van de PCA, over de periode 1988-1991, wordt ingegaan op zwakheden van het huidige systeem ${ }^{34}$ De zwakheden zijn niet van dien aard dat het gehele systeem gewijzigd zou moeten worden. Desalniettemin doet de $P C A$ in haar rapport enkele aanbevelingen. De $P C A$ zou duidelijker regels gesteld willen zien over het opstellen van de disciplinaire aanklacht, over rechtsbijstand woor agenten èn klagers, over de samenstelling van het tribunaal en over de rol van de hoofdcommissaris in de procedure. Hetgeen de $P C A$ het meest dwars zit in de procedure, is het feit dat de hoofdcommissaris enkele van zijn taken kan delegeren, waardoor bepaalde - zwaardere - sancties wegvallen ${ }^{385}$ De bewijslast in disciplinaire zaken is volgens de $P C A$ te zwaar. Deze zware bewijslast weerhoudt de $P C A$ er vaak van een aanklacht te formuleren.

Het onderzoek naar klachten tegen de politie geschiedt door de politie zelf. Twijfel kan rijzen over de gedegenheid en de onpartijdigheid van een onderzoek, verricht door police policing the police. ${ }^{386}$ We kunnen stellen dat de $P C A$ slechts een marginale rol vervult in de hele klachtenprocedure. De

382. $\rightarrow$

nary offence, or the conduct involved may differ. Where this is so, there is no bar to disciplinary proceedings, because the two offences are not in substance the same. ... a criminal charge of perjury involves proof that an allegedly false statement was material to the proceedings in which it was made, but a disciplinary chatge of falsehood does not; ...'Police Complaints and Discipline Procedures, 1983.

383. 'The relationship between criminal and disciplinary proceedings: revised guidance to chief officers', Police Complaints and Discipline Procedures, Home Office, Cmnd. 9072, 1983.

384. In het jaarverslag over 1991 komt de PCA weer hierop terug Police Complaints Authority, 1992, p. 26.

385. Police Complaints Authority, 1991, p. 15-16

386. Scraton, 1985, p. 48; zie ook Police Complaints Authority, 1991, p. 24; Maguire and Corbett, 1991, p. 1.76; zie ook Rose, 1996, 279-280. 
PCA krijgt lang niet alle klachten onder ogen hetgeen zij ook beseft. ${ }^{387}$ Bovendien kan zij het onderzoek naar de gegrondheid van de klacht niet feitelijk leiden. De klager heeft, zoals we gezien hebben, geen inzage in het rapport dat opgesteld wordt over het onderzoek. Wat dat betreft zegt Sanders dat de klachtenprocedure fails all due process tests (openness, not allowing officials to be judges in their own cause, giving all parties a fair hearing, and so forth) and fails to deter the police from crime control practices in general and law-breaking in particular. ${ }^{388}$ Ook dit laatste punt zou de $P C A$ graag verbeterd willen zien.

\subsubsection{De effectiviteit van de klachtenprocedure}

Het is de vraag of en in welke mate het publiek gebruik maakt van de klachtenprocedure. Het neerleggen van een klacht door de burger over verkeerd politieoptreden heeft voor een groot deel te maken met het vertrouwen van burgers in de politieorganisatie. ${ }^{389}$ Mensen die een groot vertrouwen in de politie hebben zijn eerder bereid hun beklag te doen over het optreden van agenten, aangezien ze van mening zijn dat de politie van hun klacht zou kunnen leren. Niet alleen het vertrouwen speelt echter een rol. Ook de daadwerkelijke gegrondverklaring van klachten is een belangrijk aspect. In 1985 werden er in Londen 5.462 klachten geteld. Van dit grote aantal werden slechts 150 klachten gegrond verklaard ${ }^{390}$ Klachten van het blank publiek hebben een veel grotere kans om gegrond verklaard te worden dan klachten van kleurlingen. Uit de British Crime Survey van 1982 blijkt dat van een aanzienlijke groep mensen die beweert niet goed behandeld te zijn door de politie, slechts een gering aantal mensen daadwerkelijk een klacht indient. ${ }^{391}$ In dit groots opgezette onderzoek werd ook naar de reden gevraagd waarom mensen besloten toch geen klacht in te dienen, wanneer zij eigenlijk van mening waren dat het gedrag van de politie aan de kaak gesteld moest worden. Het overgrote deel dacht dat een klacht niet

387. Police Complaints Authority, 1991, p. 19.

388. Sanders, 1994, p. 808-809.

389. Mensen lijken daarnaast geen vertrouwen te hebben in de PCA. Zie Maguire and Corbett, 1991, p. 176.

390. Sanders, 1994 , p. $807-808$, geeft drie verklaringen hiervoor:

a) klachten zijn ongerechtwaardigd;

b) politie-onderzoek is bevooroordeeld;

c) bewijs tegen malpractice is moeilijk te verkrijgen.

Verklaringen aj en b) vindt Sanders maar gedeeltelijk waar. Het grootste probleem vormt verklaring $\mathrm{c}$ ).

391. Southgate en Ekblom, 1984, p. 23. 
veel zou helpen, was bang om een klacht in te dienen of dacht dat het indienen van een klacht hen in moeilijkheden zou brengen. ${ }^{392}$

Vóor 1985 werd $45 \%$ van alle klachten ingetrokken. Deze klachten waren voornamelijk minder ernstig van aard. $\mathrm{Na}$ de invoering van de Police and Criminal Evidence Act is dit percentage gedaald vamwege de mogelijkheid tot informele afdoening van de klacht. ${ }^{393}$ Er zijn gevallen waarbij de politie aandringt om de klacht in te trekken. ${ }^{394}$ Deze actie van de politie hoeft niet per se negatief bedoeld te zijn. De politie beschikt over verscheidene technieken om intrekking van de klacht te bereiken. Ze kan de geringe kans van slagen vermelden, een vijandige of negatieve houding aannemen, terughoudend zijn om klachten te noteren of de vervelende kanten van de procedure overdrijven. ${ }^{395}$ Klagers zelf geven de volgende redenen aan waarom ze besluiten hun klacht in te trekken: ze zijn ontevreden over de procedure; ze krijgen sympathie voor de politie; ze voorzien een ongunstige affoop; hun verontwaardiging is bekoeld; ze hebben angst woor represailles van de politie (bijv. alsnog vervolgen), en hun beoogde strategie met de klacht is geJukt of heeft gefaald. ${ }^{396}$ Van de klachten die in 1984 ingediend werden, is minder dan $1 \%$ gegrond verklaard. ${ }^{39 \%}$

Een toenemend aantal advocaten adviseert de mensen die ontevreden zijn over het optreden van een agent om een civiele actie te ondernemen die een veel grotere kans van slagen heeft. De ontevredenheid omtrent de huidige klachtenprocedure is er derhalve de oorzaak van dat in toenemende mate gebruik wordt gemaakt van het civiele recht om iets tegen een agent te ondernemen ${ }^{398}$ Een civiele procedure heeft daarnaast nog enkele voordelen boven de klachtenprocedure. De klager kan via de civiele procedure schadevergoeding eisen. Verder houdt de klager controle over de zaak en is de bewijswoering eenwoudiger. De zaak moet bewezen worden on the balance of probabilities, en niet beyond reasonable doubt. De klager kan steun vragen wan een advocalat. De rechter kan de politie bevelen stukken te overhandigen, die anders niet in de openbaarheid zouden komen (disclo-

392. Dit laatste is bijvoorbeeld het geval als de klager tegelijkertijd verdacht wordt van een strafbaar feit. De vrees kan dan bij de klager bestaan dat een klacht wan zijn kant over het optreden wan de politie in zijn nadeel zou werken of op een andere wijze invloed zou kunnen vitoefenen op de afloop van zijn zaak.

Southgate en Ekblom, 1984, p. 24.

393. Brown, 1987, p. 21.

394. Zie het onderzoek van Maguire and Cotbett, 1991.

395. Brown, 1987, p. 29.

396. Brown, 1987, p. 23.

397. Harrison, 1987, p. 8-9; zie ook Sanders, 1994, p. 807.

398. Clayton en Tomlinson, 1987, p. 10-11; zie ook Sanders, 1994, p. 809. 
sure). Als latste voordeel wordt vermeld dat de politie via deze procedure in het openbaar ter verantwoording wordt geroepen. ${ }^{399}$

\subsection{Conclusie}

Naar aanleiding van de dood van Blair Peach in 1979 werd er vanuit regering en parlement actie ondernomen. Dit had de bepalingen over de klachtenprocedure in de Police and Criminal Evidence Act 1984 tot gevolg. Toch woldoet de klachtenprocedure niet geheel. ${ }^{4(2)}$ Al kan het de intentie van de regering zijn geweest de procedure werkelijk te verbeteren, de praktijk wijst uit dat het vertrouwen van niet alle burgers in de klachtenprocedure groot is. De partijdigheid van de politie is hier in het geding. Liever laat men het indienen van een klacht achterwege of men begint met behulp van een adwocaat een civiele procedure die een grotere kans van slagen heeft.

Controlle via de klachtenprocedure functioneert niet voldoende. Tijdens een gesprek met een assistant chief constable (operations) ${ }^{401}$ in 1992 werd mij bevestigd dat de burgers huiverig staan tegenover een politie die zichzelf onderzoekt. Ook de politie ziet dat in. Evenwel werd daarnaast gesteld dat de politie als enige in Groot-Brittannie in staat is om een zo onafhankelijk mogelijk onderzoek in te stellen naar misstanden binnen de eigen organisatie. Een oplossing zou kunnen zijn dat dat onderzoek zou geschieden door een los van de politie staande dienst. Een dergelijke dienst zou volgens de assistant chief constable evenwel over onvoldoende onderzoektechnieken beschikken en lang niet zo diepgaand onderzoek doen als de politie op dit moment in Groot-Brittannië doet.

399. 'In 1994, there were 194 settled actions against the police in London: a figure which amounts to only a tiny proportion of the total contacts of all kinds beween the police and the public. But in virtually all of these cases of avowed police misconduct, there was no substantive action against the officers concerned. The rotten apples remain in the barrel.' Rose, 1996, p. 288.

400. Vgl. Roording, 1996, p. 23-39.

401. G.E. Markham, Chelmsford, Essex, oktober 1992. 


\section{De rellen in Brixton}

\subsection{Inleiding}

De politie in Engeland en Wales is in zeer grote mate onafhankelijk. Het afleggen van verantwoording is slechts in sporadische gevallen noodzakelijk (vgl. de Metropolitan Police in Londen). Formeel bestaat er derhalve geen rechtstreekse gezagslijn tussen de politiekorpsen en regering. Enkele gebeurtenissen in het Thatcher-tijdperk laten echter iets anders veronderstellen.

De Thatcher-regering was zeer conservatief en de bezuinigingen die deze regering voorstond betroffen voornamelijk de sociaal zwakkeren: kleurlingen en werkloze jongeren. De bekende Brixton-rellen gaven de onrustgevoelens van de jongeren aan in dit deel van Londen. In dit specifieke geval werd er gestreden tegen de politie als de personificatie van de veroorzaker van de ellende (i.c. de regering). Tijdens de mijnstaking van 1984-1985 trad de politie op als beschermvrouwe van de werkwilligen, dit geheel in overeenstemming met de wensen van de regering Thatcher.

In dit hoofdstuk bespreek ik deze twee voorvallen, maar ik ga tevens na in hoeverre het ontkennen van een politieke relatie tussen politie en regering het affeggen van verantwoording tegenwerkt en de mythe van de onafhankelijkheid in stand houdt.

\subsection{De achtergrond van de Brixton rellen}

Brixton is een wijk in Zuid-Londen. Terwij] het vroeger een welvarend en commercieel centrum was, raakte deze wijk sinds de jaren zeventig in verval. Een aanzienlijk aantal woningen verkeerde in (zeer) slechte staat. De woningnood was hoog. De meeste huizen werden verhuurd maar door huurbazen niet gerenoveerd. Eind jaren zeventig werd Brixton onderworpen aan een renovatie-project en konden ondernemingen en burgers van de plaatselijke overheid subsidie krijgen voor verbetering of uitbreiding van hun bedrijven en huizen. ${ }^{402}$ In 1981 was een aantal woningen al opgeknapt, maar er zou nog veel moeten gebeuren. Vanwege de slechte toestand in de wijk vertrokken bedrijven en winkeliers naar andere delen van de stad. Ook een deel van de bevolking verhuisde, met name mensen van middelbare leeftijd met een baan. Wat overbleef waren vooral jonge mensen, jonge ouders met kinderen en éénoudergezinnen. Het percentage kleurlingen was in Brixton groter dan in de rest van Londen of in Engeland $\left(36 \%{ }^{403}\right)$. Velen waren

402. Scarman, 1986, p. 19.

403. Scarman, 1986, p. 24. 
werkloos ${ }^{404}$ of hadden laag betaalde banen. De werkloosheid onder de leeftijd van 19 jaar was meer dan $50 \%$. De meeste jongeren brachten veel tijd verveeld op straat door, waardoor zij eerder in aanraking kwamen met de lokale politie. ${ }^{45}$ Tegen deze achtergrond moeten de rellen gezien worden die plaatsvonden op 10,11 en 12 april 1981 .

\subsection{De gebeurtenissen op 10-12 april 1981}

Tijdens deze dagen kwamen honderden jongeren in opstand tegen de politie in hun wijk. Wat was de directe aranleiding? In de avond van vrijdag 10 april 1981 werd de politie ervan beticht een jonge kleurling mishandeld te hebben. ${ }^{406}$ Binnen de kortste keren stonden 30 tot 40 agenten tegenover zo'n 100 kleurlingen. De orde werd binnen korte tijd hersteld, maar dezelfde avond en de volgende morgen was er een vrij grote politiemacht in het centrum van Brixton aanwezig. Op zaterdag vond er weer een incident platats toen twee agenten een bestuurder van een auto controleerden op het bezit van drugs. Ook op dat moment bemoeiden omstanders zich met de situatie en kwam het tot een nog grotere uitbarsting tussen politie en jongeren. Hetzelfde kan gezegd worden van de gebeurtenissen op zondag. Dodelijke slachtoffers waren er gelukkig niet te betreuren. ${ }^{407}$ Veel gewonden waren er daarentegen wel.

\subsection{Het Parlement}

Op 13 april 1981 makte de Home Secretary William Whitelaw in het parlement bekend dat hij Lord Scarman bereid had gevonden een onderzoek in te stellen op basis van artikel 32 van de Police Act 1964 naar "... the disorder in Brixton on 10 to 12 April and to report, with the power to make

404. Van alle werklozen in Brixton was $25,4 \%$ kleurling. Scarman, 1986, p. 27.

405. Scarman. 1986, p. 29; De criminaliteit, met name het aantal inbraken en berovingen, was in vergelijking met de rest van Londen hoog. Lea en Young, in Cowell. Jones en Young, 1982, p. 9.

406. De politic van Brixton verleende hulp aan een jongen die slachtoffer was geworden van een steekpartij. Terwijl de politie - samen met de jongen - wachtte op een ambulance, verzamelde zich on de auto een menigte. De menigte bestond vooral uit kleurlingen, die van mening waren dat de politie de jongen, ook een klewrling, zo toegetakeld had. Zij duwden de agenten opzij, namen de gewonde jongeman op en enkelen brachten hem naar het ziekenhuis. De menigte ging na dit incident niet uiteen, maar begonnen stenen te werpen naar de politie. Deze vroeg via de radio om versterking. Zie ook Baldwin en Kinsey, 1982, p. 232-236.

407. Scarman, 1986, p. 12-13. 
recommendations, ${ }^{408}$ Sinds 1964 heeft de Home Secretary pas twee maal van deze bevoegdheid gebruik gemaakt. De eerste keer was een onderzoek naar de Red Lion Square-rellen in 1974, de tweede keer dit onderzoek naar de Brixton-rellen. In beide gevallen werd het onderzoek verricht door Lord Scarman. ${ }^{409}$ In tegenstelling tot hetgeen normaal in de politiek gebeurt was Whitelaw heel snel met het instellen van een onderzoek. Brixton vormt een deel van de hoofdstad en voor Londen is de Home Secretary wel degelijk verantwoording verschuldigd aan het parlement. Het is derhalve te begrijpen dat Whitelaw het parlement een stap voor wilde zijn en uit zichzelf een onderzoek voorstelde om vervelende vragen te vermijden. ${ }^{410}$ Het House of Commons ging akkoord met het onderzoek, vooral nadat door kamervragen $^{411}$ bleek dat Lord Scarman ook in zijn onderzoek de onderliggende oorzaken, met name de invloed van de omgeving en van de economische situatie op de jongeren, mocht betrekken.

\subsection{Het Scarman-rapport}

Scarman beschrijft in zijn rapport eerst de achtergrond en setting van de wijk Brixton en gaat dan uitvoerig in op de gebeurtenissen van vrijdag 10 , zaterdag 11 en zondag 12 april 1981. Zijn bevindingen geven aan dat de rellen spontaan ontstaan zijn. De rellen waren een uitbarsting van kwaadheid en wraak van jonge kleurlingen tegen de overheersend blanke politie. De politie had zich niet onredelijk gedragen, al heeft Scarman kritiek op het feit dat de politie vrijdagavond en zaterdag intensief gebruik gemaakt had van stop and search bevoegdheden hetgeen op de jongeren als een rode lap op een stier werkte. ${ }^{412}$ Scarman ziet als reden voor de vijandigheid van jonge kleurlingen tegen de politie een gebrek aan vertrouwen in de politie. Dat gebrek is o.a. ontstaan vanwege de hardere politieaanpak, een wantrouwen van de burgers in de klachtenprocedure en een racistische en van veel voor-

408. 3 H.C. Deb., 6th Ser, kolom 21-22.

409. Zie over de Red Lion Square-rellen, warin een dodelijk slachtoffer viel: Scarman, 1975; Harrison, 1987, p. 122.

410. Het is de vraag of Whitelaw ook zo snel een onderzoek ingesteld zou hebben als de rellen in een andere stad dan Londen plaatsgevonden zouden thebben. Toen in 1980 rellen in Bristol uitbraken, weigerde de Home Secretary een onderzoek in te stellen. 3 H.C. Deb., 6ih Ser., kolom 29.

411. Mr. Roy Hattersley, Mr. John Fraser en Mr. John Tilley, 3 H.C. Deb., 6th Ser., kolommen 22-24.

412. Operatie Swamp ' 81 was op dat moment in volle gang, teneinde de stratcriminaliteit terug te dringen. Te dien einde waren er meer agenten dan normaal op 10 en 11 april op de been in Brixton. De politie kwam onvermijdelijk in conflict met de jongeren. Dat dit conflict een racistische lading had, hoeft geen verbazing te wekken. Scarman, 1986, p. 43. 
oordelen voorziene houding van agenten. De werhouding tussen burgers en politie was in Brixton wel heel slecht. Bovendien bestonden er tussen beide groepen helemaal geen overlegstructuren. Scarman was van mening dat er daarnaast zwakheden waren in de bekwaamheden en de uitrusting van agenten om krachtig te reageren op rellen. ${ }^{413}$ Een excuus was natuurlijk wel dat rellen in een dergelijke ernstige vorm al 200 jaar in Engeland en Wales niet meer voorgekomen waren. ${ }^{414}$ Al deze factoren leidden ertoe dat - los van de schuld van de rellenschoppers - de politie en de lokale overheid van Brixton op enigerlei wijze verantwoordelijk geacht konden worden voor het uitbreken van de rellen in april 1981.

Vanwege het feit dat discriminatie op grond van ras in de Britse samenleving en ook bij de politie woorkomt, zijn veel van de aanbevelingen van het rapport van Scarman gericht op het verminderen hiervan. ${ }^{415}$ Scarman adviseerde de overheid 0. a. om meer kleurlingen te werven bij de politie en om aspirant-agenten een langere opleiding te geven met meer aandacht woor de voorkóming van en de omgang met het fenomeen van rellen en andere ordeverstoringen. Daarnaast deed hij op tal van andere gebieden woorstellen. Zo stelde hij voor overleg tussen politie, politiecommissie en burgers verplicht te stellen. ${ }^{416}$

De bevoegdheid van de politie tot stop and search over te gaan was volgens Scarman in sommige gevallen noodzakelijk voor de bestrijding van de straatcriminaliteit. ${ }^{417}$ Wel was deze bevoegdheid slecht in de wet geregeld en zou met waarborgen omkleed moeten worden. Ergens anders in het rapport echter betwijfelt Scarman of deze methode wel zo effectief is. ${ }^{418}$ "... (T) he evidence ... is not clear that a street saturation operation does diminish street crime: it may well only drive it elsewhere. And, after the operation is ended, street crime returns. If, therefore, such an operation is, in the short term, the only direct action possible against street crime, its efficacy is doubtful. But in the long term the development of a style of policing which is designed to secure public approval and respect is likely to be more effective." Ook de klachtenprocedure functioneerde niet, omdat de burgers te weinig vertrouwen in de politie hadden om onpartijdig klachten te onderzoeken. Vandaar dat Scarman voorstelde om al in een vroeg stadi-

413. Scarman, 1986, p. 115-118.

414. In 1780 waren er de Gordon riots. Noord-Ierland wordt hier buiten beschouwing gelaren.

415. Scarman, 1986, p. 150.

416. Scarman, 1986, p. 150.

417. Scarman, 1981, para, 5.46 .

418. Scarman, 1981, para. 4.78; zie ook hierover Baldwin en Kinsey, 1982, p. 240241. 
um een onathankelijk element in te bouwen in de klachtenprocedure, met bovendien de mogelijkheid dat getracht zou moeten worden verzoening tot stand te brengen tussen agent en klager. Scarman betrok ook in zijn onderzoek de woningnood, de school en de werkloosheid. Hoewel hij ook op dit punt de aandacht wan de overheid vroeg voor de problemen van kleurlingen, heeft hij geen aanbevelingen gedaan.

\subsection{Bespreking van het rapport van Scarman}

Vanuit de links radicale hoek binnen de politiek is de opvatting geventileend dat het rapport van Scarman niet zo vooruitstrevend is als het wil zijn. Weliswaar worden werkloosheid, rassendiscriminatie en woningnood als de belangrijkste oorzaken van het uitbreken van de rellen genoemd, een structurele verandering zoals politieverantwoordelijkheid creëren tegenover bijvoorbeeld het parlement, wordt door Scarman niet voorgesteld. ${ }^{419}$ Hetgeen Scarman voorstelt is het werbeteren van de verhouding tussen politie en de (met name) zwarte bevolking. Het rapport gaat derhalve voor deze groep niet ver genoeg. De oplossingen van de conservatieven daarentegen om rellen tegen te gaan zouden zijn: het verzwaren van straffen en het verschaffen van extra middelen aan de politie, terwijl de liberalen een nog sterkere nadruk op het recruteren van kleurlingen wilden leggen. ${ }^{420}$

De meeste aanbevelingen die Scarman in zijn boek voorstelt zijn dus gericht op een beter contact tussen politie en zwarte jongeren. Scarman hanteert in zijn rapport concepten die ook gebruikt werden bij de oprichting van de politie in 1829. Ook toen werd uitgegaan van twee beginselen, te weten consent and balance en independence and accountability, bij de vervulling van de drie taken van de politie: "The prevention of crime ... the protection of life and property, the preservation of public tranquillity. ${ }^{321}$ Het kenmerkende van het rapport van Scarman is dat hij erop wijst dat het belang van de wetshandhaving niet moet prevaleren boven het belang van de openbare orde en rust. Hier legt hij nadruk op het eerste beginsel, waar een balans gezocht moet worden nussen de verschillende taken van agenten. Scarman is van mening dat"... the maintenance of public tranquillity comes first. ${ }^{422}$ Het gebruik van de "Swamp ' 81 "-methode, de onmiddellijke aanleiding van de rellen, had volgens Scarman derhalve achterwege moeten blijven. ${ }^{223}$ Sherman, die onderzoek heeft verricht naar de relatie tussen politie-zwarte bevolking in de VS na rellen daar, concludeerde in zijn on-

419. Lea en Young, 1982, p. 19; zie ook Taylor, in Benyon, 1984, p. 32-33.

420. Taylor, 1984, p. $30-32$.

421. Reiner, 1985, p. 200. Lord Scarman, 1981, para. 4.56 .

422. Scarman, 1981, para. 4.57.

423. Reiner, 1985 , p. 200 . 
derzoek dat vooral een verandering in de waardering van de belangen, zoals hierboven door Scarman omschreven, een werbetering teweeg had gebracht in de relatie nussen de politie en de bevolking in Amerika. ${ }^{424}$ Juist de nadruk op de openbare orde en rust kan volgens Sherman en Scarman bijdragen tot herstel van vertrouwen.

\subsection{Acceptance of the Report: The House could not have looked for firmer guidance of intent ${ }^{425}$}

Op 25 november 1981 bood Home Secretary Whitelaw het rapport van Lord Scarman aan het House of Commons aan. Dit rapport werd op 10 december besproken. De inleiding van Whitelaw werd gekenmerkt door niets dan lof aan het adres van Scarman. De meeste aanbevelingen werden door de minister dan ook geaccepteerd. ${ }^{426}$ Zo wilde hij de training van agenten verbeteren, zowel van de nieuwe lichting agenten als van agenten die al in dienst waren. De klachtenprocedure zou onderwerp van onderzoek worden van een Select Committee on House Affairs. Ook over een wettelijke regeling van overlegstructuren wilde hij discussiëren met vertegenwoordigers van politiecommissies en hoofdcommissarissen. De minister deed toezeggingen over het geven van extra (financiële) steun aan kleurlingen die daaraan behoefte hadden. De minister kondigde verder aan dat de regering $25 \%$ meer beschikbaar zou stellen voor het verbeteren van binnensteden. Hij vroeg het Huis derhalve het vlugge antwoord en de bedoelingen van de regering te onderschrijven. ${ }^{427}$ De oppositie makkte aan het begin van het debat al duidelijk dat zij dat niet zou doen. De oppositie stond eveneens ten volle achter het rapport van Scarman. Maar, de aanbevelingen van Scarman zouden dan wel integraal ingevoerd moeten worden. Tenzij de regering meer geld wilde uittrekken voor allerlei verbeteringen ten behoeve van de kleurlingen, wilde de oppositie het Huis op dit punt verdelen en niet instemmen met de bedoelingen van de regering. ${ }^{428}$ Maar met een meerderheid van stemmen ${ }^{429}$ haalde het voorstel van de minister het echter wel.

\subsection{Het verdere verloop}

Scarman was niet de enige die door allerlei hervormingen binnen het politieapparaat de verhouding tussen politie en burgers wilden verbeteren. De

424. Zie Reiner, 1985, p. 201.

425. Mr. Whitelaw, 14, H.C. Deb., 6th Ser, kolom 1001.

426. 14. H.C. Deb., 6th Ser., kolommen 891-892, 1001-1008.

427. 14, H.C. Deb., 6th Ser., kolom 1008.

428. 14, H.C. Deb., 6th Ser., kolom 1009 (Mr. Roy Hattersley), 1033 (Mr. John Tilley), 1040-1043 (Mr. John Fraser), 1069 (Mr. Gerald Kaufman).

429. 216 tegen 140; 14, H.C. Deb., 6h Ser, kolommen 1078-1080. 
Royal Commission on Criminal Procedure (waarover later meer) heeft ook aanbevelingen op dit terrein gedaan. Al in juni 1977 was door de Labourregering aangekondigd dat een Royal Commission ${ }^{430}$ on Criminal Procedure opgezet zou worden, met als taak '... to consider the investigation of offences in the light of police powers and duries as well as the rights and duties of suspects ... ${ }^{431}$ De commissie was samengesteld uit personen van de rechterlijke macht, politie en advocatuur. Voorzitter van de commissie was Sir Cyril Philips, een professor van London University. In januari 1981 was het rapport van de commissie, dat uit twaalf verschillende deelrapporten bestaat, klaar. Veel aandacht van het rapport ging uit naar de scheiding tussen opsporing en vervolging. De commissie stelde voor om voor elk politiekorps een eigen prosecution service op te zetten en verder werden de rechten van burgers en de bevoegdheden van de politie vastgelegd. Het voorstel van de commissie om een zelfstandig vervolgingsorgaan op te richten, heeft nog enkele jaren moeten wachten alvorens verwezenlijkt te worden. Pas in november 1984 werd hiertoe in het parlement een wetsontwerp ingediend. ${ }^{432}$

Het Scarman-Rapport en het rapport van de Royal Commission on Criminal Procedure $^{433}$ hebben geresulteerd in de Police and Criminal Evidence Bill. In november 1982 diende Whitelaw het ontwerp voor het eerst in. De Bill bevatte vergaande regelingen betreffende stop and search, huiszoeking, voorlopige hechtenis, het verhoor van verdachten, uitsluiting van bewijsmateriaal, samenwerkingsverbanden tussen politie en de gemeenschap en de klachtenprocedure, waarin de aanbevelingen van Scarman verwerkt waren. Tijdens de behandeling van het ontwerp in het Huis was veel kritiek te horen. Voorstellen zouden o.a. veel te ver gaan: burgers en bestuurders van motorvoertuigen zouden veel eerder dan voorheen door de politie staande kunnen worden gehouden teneinde verantwoording af te leggen. Het feit dat verdachten tot 36 uur "incommunicado" ${ }^{\prime 434}$ en tot 96 uur zonder aanklacht vast zouden kunnen zitten, werd door de oppositie onaanvaardbaar ge-

430. Het belang dat gehecht wordt aan het rapport van een Royal Commission is vergelijkbaar met dat van de Nederlandse parlementaire enquêtecommissic. De aanbevelingen worden besproken in het parlement. De samenstelling van een Royal Commission verschilt wel met de samenstelling van een enquêtecommissie in Nederland.

431. Zander, 1985, p. XV.

432. Prosecution of Offences Bill 1984; zie Zander, 1985, p. XV.

433. Ook well de Philips-commissie genoemd.

434. Zonder contact met wie dan ook. 
acht. ${ }^{435}$ Bovendien was volgens de oppositie het onafhankelijk element in de klachtenprocedure mar zeer mondjesmaat ingevoerd. ${ }^{436}$

In mei 1983 werd het parlement onbonden en na talrijke amendementen werd het wetsontwerp weliswaar behoorlijk gewijzigd een jaar later door de nieuwe Home Secretary Leon Brittan weer ingediend. In de debatten in het House of Commons werd herhaaldelijk verwezen naar bovengenoemde rapporten. ${ }^{437}$ De Police and Criminal Evidence Bill (PACE Bill) ontving op 31 oktober 1984 na veel debatten in het parlement toch het Royal Assent en is in de loop wan 1985 en 1986 in werking getreden. ${ }^{488}$

\subsection{Na Scarman}

In hoeverre is nu gehoor gegeven aan de aambevelingen van Scarman? Het rapport werd vol lof ontvangen in het parlement en veel van de voorstellen zijn aangenomen en opgenomen in PACE. Scarman had in zijn rapport de opmerking gemaakt dat de openbare orde en rust boven alles staan. Toch komt een agent dan al gauw in conflict als hij met dwingende, harde maatregelen moet werken, bijwoorbeeld in het geval dat demonstraties uit de hand lopen. Scarman had dit probleem gesignaleerd. De politie heeft de bewoegdheid om geweld te gebruiken. Maar, zegt ook Reiner, het gebruik van geweld is het meest effectief en door de bevolking het meest geaccepteerd (policing by consent ${ }^{439}$ ), indien er zo weinig mogelijk gebruik van wordt gemaakt. ${ }^{40} \mathrm{Om}$ een Nederlands voorbeeld te geven: wanneer de overheid bij elke demonstratie of pandontruiming de Mobiele Eenheid in gevechtstenue optrommelt, zal dat op een gegeven moment weinig indruk maken op krakers, relschoppers en studenten en veel kritiek en weinig steun krijgen van alle lagen van de bevolking. ${ }^{441}$

435. Mr. Gerald Kaufman, 60, H.C. Deb, 6th Ser., kolom 385, en Mr. Robert Maclennan, 60, H.C. Deb, 6th Ser., kolommen 394-395.

436. Mr: Roy Hattersley, 33, H.C. Deb., 6th Ser., kolommen 157-164.

437. 33, H.C. Deb., 6th Ser, kolommen 150-152.

438. 65, H.C. Deb., 6th Ser., kolom 1389; zie verder over PACE: Michael Zander, Police and Criminal Evidence Bill L-VIII, The Amendments I-II, in: New Law Review, March 4, 11, 18, 25, April 8, 15, 22, 29, July 22, 29, 1983.

439. Zie over dit begrip: Oxford, in Benyon, 1984, p. 114-124.

440. Reiner, 1985, p. 203.

441. Van Reenen. 1979, geeft aan hoe de politie in Nederland in jaren ' 60 en '70 naar een gedifferentieerd geweldsbeleid overgestapt is bij de beheersing van demonstraties. 
De rellen in Brixton stonden niet op zichzelf. In 1980 in Bristol en later in 1981 in Liverpool en Manchester vonden er stedelijke rellen plaats. ${ }^{442}$ We zien nu sinds de rellen in 1980-1981 de tendens in Engeland dat men op grote schaal overgaat tot riot-training. Dit is aan een kant wel te begrijpen, aangezien de politie helemaal geen ervaring had met rellen en er tijdens de rellen veel slachtoffers aan de kant van de politie waren. ${ }^{4.3}$ Reiner signaleert duidelijk een verstrengeling van het beleid van de politie met de politiek van de toenmalige regering van Thatcher. ${ }^{444}$ Het gevaar bestaat echter dat men dan ook vaker over zal gaan tot een hardere aanpak van bepaalde problemen hetgeen de verhouding tot de bevolking niet zal verbeteren. De gevolgen hiervan kunnen het best geilllustreerd worden aan de hand van de mijnstakingen van 1984 .

\subsection{De staking van 1984}

In 1984 is een jaar geweest waarin veel kritiek op de politie is geweest. De reden voor die kritiek was het feit dat de politie zich niet onpartijdig opstelde gedurende de staking van 1984-1985.

De staking begon officieel op 12 maart 1984. Aanleiding van de mijnstaking van 1984 was de intentie van de overheid en de National Coal Baard om enkele mijnen te sluiten. ${ }^{445}$ De mijnindustrie had financiële moeilijkheden en wilde derhalve verliesgevende mijnen sluiten. $D e N C B$ had tot dan toe het beleid gevoerd om voornamelijk geld te investeren in mijnen in het zuiden van Engeland en niet in Schotland of Wales. Bij de beslissing om mijnen te sluiten werd juist rekening gehouden met het bedrag dat geïnvesteerd was in bepaalde mijnen hetgeen derhalve zeer nadelig uitviel voor mijnen in Schotland en Wales. ${ }^{46}$ De National Coal Board $(N C B)$ was niet van plan om acties van de (stakende) mijnwerkers via de burgerlijke rechter

442. Jefferson, 1990, p. 7.

443. Baldwin en Kinsey, 1982 , p. 230 , noemen een aantal van 279 gewonde agenten.

444. Cfr. Reiner, 1985, p. 204; Reiner, 1995, p. 9. Judge, in zijn bespreking van het boek van Reiner, is het wat dit pum betreft miet cens met Reiner. De politie is tot riot-training overgegaan, omdat de Home Secretary dat bevolen zou hebben om het toenemende geweld tegen de rule of law te bestrijden. Judge, 1985, p. 305-307. Het ontstaan van de riot-training kan ook op andere wijze verklaard worden: het breken van de vakbonden en van pickets bij stakingen.

445. Hierbij ging het om 20 mijnen en 20.000 arbeidsplatsen op een total van 179 mijnen. Dit was aangekondigd op 6 maart 1984. Darnaast bestonden er plannen om nog eens 50 mijnen te sluiten, hetgeen een verlies van 75.000 arbeidsplaatsen betekende, volgens de NUM (National Union of Mineworkers). McCabe, Wallington, 1988 , p. 18.

446. Fine, Millar, in Fine, Millar, 1985, p. 5. 
te voorkomen. In plaats daarvan wilde men de hulp van het strafrecht ${ }^{447}$ en van enkele duizenden politieagenten inroepen. De staking zou gebroken moeten worden. Helaas werd er van overheidswege niet aangedrongen op onderhandelingen. Vanaf het begin derhalve stond de politie onder druk. Dit heeft nadelige gevolgen gehad voor de verhouding tussen bevolking en politie in de gebieden waar gestakt werd. ${ }^{448}$

Het voornaamste doel van de politie bestond wit het verminderen van de effectiviteit van het massale posten van stakende mijnwerkers. Over het algemeen verliep het posten gedurende de staking vrij rustig en was politieoptreden niet nodig. Toch zijn er in het stakingsjaar 9.808 mensen gearresteerd, warvan de meeste voor kleine delicten. ${ }^{449}$ Inzittenden van auto's op autowegen, waarvan men vermoedde dat het stakers waren die bij mijnen in andere gebieden in Engeland wilden gaan posten, hebben vaak rechtsomkeert moeten maken. Het niet woldoen aan een dergelijk bevel van de politie had de onmiddellijke arrestatie tot gevolg. ${ }^{450}$

Het gedrag van politieagenten heeft tijdens de staking op sommige momenten duidelijk te wensen overgelaten. De politie werd ervan verdacht partijdig te zijn in het conflict tussen bond en werkgever. De stakende mijnwerkers kregen dit gevoel vooral toen agenten hun woertuigen binnen de poorten van de kolenmijn parkeerden en hiervanuit ook vaker acties begonnen tegen de stakers. ${ }^{451}$ Bovendien werd er door de politie vaak heel veel moeite ge-

447. 'Apart from the very narrow range of peaceful picketing at the pickets' own place of work which has statutory protection, all picketing is subject to the general criminal law.' Probleemloos picketing is dus beperkt tot het posten met het doel om op vreedzame wijze informatie te geven of vreedzam anderen over te halen te werken of niet te werken. Tezamen met picketing werd vaker een andere overtreding to lastegelegd:

- obstruction of the highway;

- conduct likely to lead to a breach of the peace;

- watching and beserring.

McCabe, Wallington, 1988, p. 31.

448. Reiner, 1985, p. 209.

449. McCabe, Wallington, 1988, p. 69.

450. Scraton, 1985. p. 152; Deze handelwijze van de politie heeft bij het publiek cen zekere mate van onrust opgeroepen, aangezien een misdaad of dreigende ordeverstoring (nog) niet gepleegd was of dreigde te ontstaan. McCabe, Wallington, 1988, p. 59-60.

451. McCabe, Wallington, 1988, p. 80 : '... frequently directing operations from there suggested to the striking miners that the police were 'MacGregor's Men', taking instructions from the Coal Board and promoting its interest.' 
daan om slechts een of twee werkwilligen te vergezellen naar hun werkp]ek. ${ }^{452}$ Verontrustend was het feit dat agenten bij acties soms hun nummer verwijderd hadden van hun uniform, zodat zij niet te identificeren waren en later niet te achterhalen waren. Bij de wegblokkades aan het begin van het conflict werd oproerpolitie (riot police) ingezet. Al in de eerste paar dagen was het politiegedrag agressief en willekeurig. Verhalen zijn bekend over het uit de auto's sleuren van bestuurders en over het inzetten van politiehonden en -paarden. De politie maakte zelfs gebruik van tactieken die zij anders alleen hanteerde bij voetbalrellen. Onbehoorlijk en uitdagend was het zwaaien met biljetten van tien Engelse ponden door de politie naar stakende arbeiders, wier inkomen door de staking sterk gereduceerd was. ${ }^{453}$ Voor een goede verhouding tussen politie en stakers kon vanaf het begin al bijna geen sprake meer zijn. In totaal zijn over de periode van maart 1984 tot maart 1985551 klachten ingediend. ${ }^{454}$ Veel van deze klachten werden later ingetrokken. De klachten die terecht kwamen bij de Police Complaints Board (de voorloper van de Police Complaints Authority ${ }^{455}$ ) hadden geen van alle disciplinaire acties tot gevolg. ${ }^{456}$

Al de pogingen die na Scarman ondernomen zijn om de relatie tussen burgers en politie te verbeteren worden op deze manier teniet gedaan en overweldigd door 'militaristische' acties van de zijde van de politie. ${ }^{457} \mathrm{Na} B \mathrm{Brix}$ ton en de mijnstaking van 1984-1985 lijkt het alsof dit soort acties van de politie genormaliseerd zijn. Eerder dan vroeger gaat de politie over tot een hardere aanpak bij demonstraties. ${ }^{458}$ Het is de vraag ò en, zo ja, welke rol de regering in dit alles heeft gespeeld en welke mogelijkheden parlementaire controle hierin zou kunnen hebben.

\subsection{Rellen in Brixton}

Sinds de rellen en het rapport van Scarman in $1981^{459}$ was er op het gebied van ordehandhaving weel gebeurd in het Engelse Brixton. Uit de ge-

452. Zoals het voorbeeld van een werkwillige in Cortonwood, die geëscorteerd werd door zo"n 1.000 agenten in november 1984. McCabe, Wallington, 1988, p. 130; Jefferson, 1990 , p. 10.

453. Lloyd, in Fine, Millar, 1985, p. 65-68.

454. Jefferson, 1990, p. 10.

455, Zie 6.4.3.

456. McCabe, Wallington, 1988, p. 88-89.

457. In de jaren ' 80 is door de toenemende criminaliteit het politieapparaat begonnen met specialistische opleidingen. Zie over de ontwikkeling van de politie tot paramilitarism: Jefferson, 1990

458. Jefferson, 1990, p. 11-12.

459. Zie hierboven. 
beurtenissen wan 1981 waren lessen getrokken. Er was sprake van een beter contact tussen bevolking en politie. Sinds de introductie van het concept Neighbourhood Policing was de straatcriminaliteit drastisch verlaagd.

Op 28 en 29 september 1985 vonden er - voor het eerst weer na vier jaar rellen plaats in Brixton. De aanleiding was de dood van Mrs. Cherry Groce, neergeschoten op 28 september om 7.00 uur 's ochtends door een agent. Agenten badden op die dag Michael Groce willen arresteren voor verboden wapenbezit. Bij de inval in zijn huis in Brixton werd Cherry Groce geraakt. ${ }^{460}$

Tegen 11.00 uur 's ochtends had zich een grote menigte verzameld voor het huis van de familie Groce. De politie legde een verklaring af, waarin de gebeurtenis betreurd werd. De zaak zou verder onder toezicht van de Police Complaints Authority onderzocht worden. Laat in de middag ging de menigte naar het lokale politiebureau. Daar werd voor het eerst met projectielen richting politie gegooid. Op het moment dat de menigte vijandiger werd, besloot de politie de mensen te verspreiden. De voornamelijk jonge mensen gingen door met het gooien van stenen naar de politie en begonnen winkels te plunderen. Om 1.00 uur 's nachts was het eindelijk kalm in Brixton. De politie probeerde de volgende ochtend de boel op te ruimen. In tegenstelling tot de gebeurtenissen van 1981 was het contact tussen politie en lokale bevolking op die zondagmorgen goed. Toch begonnen om een uur of vier 's middags weer rellen. Deze rellen waren echter niet zo hevig als de dag ervoor en er deden veel minder mensen aan mee. 's Avonds om 21.00 uur was de situatie weer normaal. De Community/Police Consultative Group for Lombeth stelde in 1986 een rapport op naar aanleiding van de rellen wan 28 en 29 september 1985. In het rapport werden aanbevelingen gedaan aan het adres van de politie, van de gemeenschap en van het Home Office. ${ }^{461}$

De aanbevelingen aan de politie hielden met name in dat de politie bij gemaakte fouten of in situaties waarin de rol van de politie onduidelijk is, opheldering moet geven over de situatie en indien nodig zo snel mogelijk duidelijk verontschuldigingen moet uiten.

\subsection{Conclusie}

De Brixton-rellen lijken in het geheel van de vijf casus die ik bespreek, een vreemde eend in de bijt. Bij de Brixton-rellen ondernam de Home Secretary actie door een onderzoek te gelasten. Door het gelasten van een onderzoek

460. Michael Groce gaf zich zelf op 29 september aan bij de politie. Marnoch, 1985 . p. 4 .

461. Community/Police Consultative Group for Lambeth, 1986. 
gaf hij indirect te kennen dat hij verantwoordelijkheid droeg voor de Londense politie. Wanneer een minister verantwoordelijkheid draagt, dan zou er een manier moeten zijn om de personen waarvoor hij verantwoording draagt bepaalde regels correct te laten naleven. De bedoeling van de minister voor het instellen van een Royal Commission is wooral geweest het woorkomen vam lastige vragen in het parlement. De bemoeienis van de minister in de praktijk op het politiebeleid is nihil. Het dragen van verantwoording is echter meer dan het enkel gelasten van een onderzoek en het indienen wan. een wetsvoorstel. Die 'meer'-waarde uit zich in het ter verantwoording roepen van een hoofdcommissaris of het structureel - en niet incidenteel controleren van het beleid. Dit laatste ontbreekt op dit moment nog. Vandaar dat ik van oordeel ben dat ook de Brixton-rellen laten zien dat de daadwerkelijke controle over de politie afwezig, zo niet gering, is. ${ }^{462}$

De slechte verhouding tussen politie en jongeren was begin jaren ' 80 de oorzaak van uitbarstingen van geweld. De jongeren waarvan het merendeel werkloos en kleurling was zagen de politie waarschijnlijk als de verpersoonlijking van de regering en haar politiek beleid. Zowel de regering als de politie zien orde en rust in de samenleving als een hoge prioriteit en al zijn er dan officieel geen banden tussem regering en politie, voor de burgers zal het lijken dat de politie in opdracht van de regering de rust in de samenleving terugbrengt. Voor Londen komt daar bovendien nog bij dat de Home Secretary formeel wel wat te zeggen heeft over de politie.

Bij de mijnstakingen van 1984-1985 is duidelijk te zien dat Thatcher gebruik heeft gemaakt van de politie, al wordt dat door politici ontkend. Daarnaast kan de verhoogde belangstelling van de politie voor de riot-training een argument zijn voor de stelling dat de politie geoefend wordt voor het inzetten bij de bestrijding van rellen en demonstraties hetgeen precies paste in het politieke beleid van Thatcher. Dat Judge daar anders over denkt - meer geweld in de samenleving dus een aangepaste training - doet weinig wan de stelling af, omdat ook uit zijn visie blijkt dat de Home Secretary harder wil optreden tegen geweld ${ }^{463}$ Cause and effect! We zien dat hier derhalve een conflict ontstaat tussen enerzijds de mythe van de normal policing en anderzijds de politiek van de rough justice.

Het wertrouwen van de jongeren in Brixton in de politie was slecht vanwege een harde politieaanpak en racisme. Later, in de jaren '84-' 85 , verminderde het vertrouwen in de politie door het soms onwettige gedrag van agenten en de politieke stellingname van de politie in het mijnwerkersconflict. Over het

462. In Nederland zou de burgemeester verantwoordelijk zijn en hel optreden van de pollitie een halt toe kumen roepen.

463. Judge, 1985, p. 305-307. 
optreden tijdens zowel de Brixton-rellen als de mijnstakingen heeft geen enkele agent zich expliciet strafrechtelijk, laat staan disciplinair, hoeven te verantwoorden. Het feit dat de regering gebruik kan maken van de diensten van de politiekorpsen zonder daarvoor in het parlement verantwoording af te leggen vind ik een zeer slechte zaak en een aantasting van het democratische gehalte van de staat. Dat bovendien de onafhankelijkheid van de politie door deze handelwijze ondergraven wordt spreekt voor zich. 


\section{Crown Prosecution Service: het Fisher rapport}

\subsection{De Confait-case}

Eind zeventiger jaren ontstond veel kritiek over het vervolgingsbeleid van de politie. Aanleiding vormde o.a. de Confait-case. Maxwell Confait werd op 22 april 1972 dood aangetroffen in zijn uitgebrande woning in Londen. In november 1972 werden drie jongens ${ }^{464}$ ter zake van moord op Confait en brandstichting schuldig bevonden. ${ }^{455}$ Uit later onderzoek bij de Court of Appeal in oktober 1975 bleek dat de veroordelingen van de drie jongens niet deugden en vernietigd moesten worden. ${ }^{466}$ Een officieel onderzoek, ingesteld op 28 november 1975, onder leiding van Sir Henry Fisher toonde aan dat de rechten van de drie verdachte jongens gedurende hun voorarrest niet in acht waren genomen. Vooral het feit dat de drie minderjarige jongens waren onderwraagd terwijl de ouders niet aanwezig waren, was een punt van kritiek. ${ }^{467}$ Het gedrag van de politie was klaarblijkelijk tekort geschoten. Op de zitting hadden de drie jongens onder ede verklaard dat zij door een agent mishandeld waren. Fisher echter concludeerde in zijn rapport dat deze verklaringen gelogen waren. ${ }^{468}$ Wel was een conclusie van. Fisher dat alle drie de jongens inbreng in de brandstichting hadden gehad en twee van de drie betrokken waren geweest bij de moord op Confait. ${ }^{469}$ Maar aangezien de Court of Appeal de veroordelingen vernietigd had, moesten de politie en de DPP de zaak verder laten rusten. ${ }^{470}$ Fisher aarzelde om uit

464. Colin George Lattimore, Ahmet Salih en Ronald William Leighton.

465. The Fisher Report (editorial), The Criminal Law Review, 1978, p. 117.

466. Lord Justice Scarman was hier de rechter. In de beroepszaak kwam naar woren dat tussen de moord op Confait en de brandstichting enkele uren gezeten moeten hebben. Ondat de jongens in hun bekentenissen gezegd hadden dat de moord en de brandstichting elkaar direct opvolgden, werden ze in de beroepszaak vrijgesproken. Price, 1978, p. 10; R. v. Lattimore, (1975), 62, Cr. App. R., 53.

467. Fisher, 1977 , p. 11.

468. Fisher, 1977 , p. 8.

469. Price heeft kritiek op dit punt in het rapport van Fisher. Terwijl de rechter de drie jongens onschuldig heeft bevonden van de moord en de brandstichting, verklaart Fisher dat ze het desondanks gedaan hebben. Price vindt het niet juist van Fisher om, na de uitspraak van rechter Scarman, in een openbaar rapport een dergelijke stellingname in te nemen, zelfs niet als hij niet gehouden is aan de uitspraak van de Court of Appeal. Price, 1978, p. 10-11: 'Confait: a purpose built case for the Royal Commission?", 1978, p. 16.

470. Later, in 1980, zou komen vast te staan dat de drie jongens Maxwell Confait zeer waarschijnlijk niet gedood hadden en evenmin brand hadden gesticht. De 
deze zaak conclusies te trekken betreffende wijzigingen van het rechtssysteem en stelde in plaats daarvan het instellen van een Royal Commission voor. ${ }^{471}$

Vrijwel direct na de uitspraak van de Court of Appeal kwamen er vragen van het Huis. ${ }^{472}$ Op 24 juni 1977 kondigde de Prime Minister James Callaghan aan dat een Royal Commission ingesteld zou worden ${ }^{43}$ De regering was van mening dat het hele strafproces herzien zou moeten worden. Daarbij zou het belang van de gemeenschap bij een effectieve bestrijding van de criminaliteit afgewogen moeten worden tegenover de rechten en vrijheden van de individuele burger. ${ }^{474}$ De Royal Commission kreeg de volgende opdracht mee: 'To examine, having regard both to the interests of the community in bringing offenders to justice and to the rights and liberties of persons suspected or accused of crime, and taking into account also the need for the efficient and economical use of resources, whether changes are needed in England and Wales in (i) the powers and duties of the police in respect of the investigation of criminal offences and the rights and duties of suspect and accused persons, including the means by which these are secured; (ii) the process of and responsibility for the prosecution of criminal offences; and (iii) such other features of criminal procedure and evidence as relate to the above; and to make recommendations. ${ }^{475}$ Wie de voorzitter van deze commissie zou moeten worden, was nog niet bekend. Gezien het feit dat de Royal Commission door een Labour-regering opgezet werd, had men de verwachting dat de commissie met name de rechten van de verdachte zou verdedigen. Vandaar dat de politieorganisatie niet zo gelukkig was met deze commissie. ${ }^{476}$

470. $\rightarrow$

zaak werd echter nooit meer heropend. 990, H.C. Deb., 5th Ser, written answers, kolommen 22-23. Zie ook Baldwin and Kinsey, 1982, p. 192-193.

471. De Confait-zaak leek daarvoor uitermate geschikt volgens een artikel in Police: "Confait: a purpose built case for the Royal Commission?", 1978, p. 16; Fisher, 1977, p. 6-7; Baldwin en Kinsey, 1982, p. 193.

472. 901, H.C. Deb., 5th Ser., written answers, kolom 159.

473. De instelling van deze Royal Commission kan gezien worden als een direct gevolg van de Confait-case. Zie 947, H.C. Deb., 5th Ser., kolom 1808.

474. 933, H.C. Deb., 5th Ser, written answers, kolom 604.

475. 933, H.C. Deb., 5th Ser., written answers, kolom 604.

476. Baldwin en Kinsey, 1982, p. 193-194 


\subsection{Het rapport van de Royal Commission}

Mr. Merlyn Rees publiceerde het rapport van Sir Henry Fisher, dat hij al in maart 1977 van Sir Henry Fisher ontvangen had ${ }^{477}$, op 13 december $1977 .{ }^{478} \mathrm{Hij}$ zou het rapport overhandigen an de Royal Commission on Criminal Procedure onder het voorzitterschap van Sir Cyril Philips, zodat deze commissie haar advies mede op grond van het Fisher-rapport kon samenstellen. ${ }^{479}$

De Britse organisatie JUSTICE, een beroepsvereniging bestaande uit juris$\operatorname{ten}^{480}$, is in 1970 de eerste geweest die in een rapport naar voren bracht dat een scheiding tussen opsporing en vervolging te prefereren was boven een systeem waarin alleen de politie deze bevoegdheden bezit. Een onafhankelijke instantie zou met name voor de vervolging zorg moeten dragen. Scheiding tussen deze functies zou een waarborg zijn voor meer fairness, objectiviteit en onpartijdigheid van de procedure. ${ }^{481}$ Toch heeft het nog een klein decennium geduurd voordat dit onderwerp weer ter sprake kwam.

Volgens de Royal Commission on Criminal Procedure leidde het oude systeem tot inefficiëntie. ${ }^{482} \mathrm{Er}$ vonden veel vertragingen plaats bij de politie met als gevolg dat in de rechtszaal vaak om uitstel gevraagd moest worden. Zaken werden slecht of onvoldoende voorbereid door de politie, waardoor in de rechtszaal eveneens bleek dat er niet genoeg bewijs anwezig was. In

477. 947, H.C. Deb., Sth Ser., kolom 1808.

478. Het lijkt er derbalve op dat de minister op eigen initiatief besloten had een Royal Commission in het leven te roepen, terwijl in feite Fisher hem dit in het rapport geadviseerd had. 941, H.C. Deb. "5th Ser., written answers, kolom 120-123; 947, H.C. Deb., 5th Ser., kolom 11808.

479. Benyon, in Benyon en Bourn (ed), 1986, p. 34: Gandy, 1988, p. 7.

480. JUSTICE heeft tot doel "the maintenance of the liberties of the subject and the highest standards of the administration of justice' in Engeland, Walles, Schotland, Noord-Ierland, Gibraltar, Hong Kong, Bermuda, Falklands en enkele andere kleine eilanden. JUSTICE is een organisatie waarin juristen (vaak ook leden wan het parlement) van allerlei politieke partijen in vertegenwoordigd zijn. Vandaar dat de invloed van JUSTICE aanzienlijk genoemd kan worden. Enkele leden van de Philips Commission, bijwoorbeeld, waren tevens lid van deze organisatie. Daarnaast mocht JUSTICE deze Royal Commission on Criminal Procedure adviseren. Zie over dit alles: Sieghart, in: Benyon and Bourn, 1986 , p. $268-278$, p. 268,270 .

481. Zie over het rapport: White, in: Benyon and Bourn (ed), 1986, p. 197 e.v.

482. Veel optreden van de politie was nog gebaseerd op de Judges' Rules, regels die door traditie en jurisprudentie de status van wet gekregen hadden. Juist door het bestaan van de ongeschreven Judges" Rules werd het jarenlang niet nodig geacht bepaalde zaken in een formele wet neer te leggen. 
het systeem voor 1986 naderde het aantal vrijspraken verscheidene jaren $50 \%$ van alle veroordelingen. ${ }^{483}$ Niet alle politiekorpsen hadden solicitors in dienst die de agenten konden adviseren over het wel of niet vervolgen van verdachten. ${ }^{484}$ Ook was van enige uniformiteit in het vervolgingsbeleid geen sprake. ${ }^{485}$ Verder gaf de commissie aan dat kritiek '... focused not only on the use made by the police of their powers of investigation, but also upon the wisdom of leaving the decision to prosecute with the people who did the investigating. ${ }^{\circ}$ Men dacht dat de politie niet in staat zou zijn van bepaalde zaken voldoende afstand te nemen en tot onpartijdige beslissingen te komen. De functies van opsporing en vervolging zouden in verschillende handen moeten liggen. ${ }^{486} \mathrm{De}$ commissie was van oordeel dat het de taak van een prosecutor zou moeten zijn dat hij '...put(s) the prosecution's case proficiently yet dispassionately'\$87. 'He must place before the court all the relevant facts, including those favourable to the accused. ${ }^{.488} \mathrm{De}$ Royal Commission on Criminal Procedure 1981 adviseerde derhalve in haar rapport van januari 1981 vervolgingsbeslissingen niet meer bij de politie te leggen. ${ }^{489}$

Een ander voorstel van de commissie was om het land in gebieden te verdelen met elk een instantie die voortaan de vervolging van strafbare feiten in

483. 1981: 43\%: 1983: 47\%; Ashworth, 1985, p. 2; Bennion, 1986, p. 5-6; Samuels, 1986, p. 39; Hierbij moet echter de opmerking gemaakt worden dat in veel van deze vrijspraken een belangrijke getwige niet was komen opdagen of een getuige op de rechtszitting van zijn oorspronkelijke verklaring, afgelegd bij de politic, om een of andere reden teruggekomen was. Niet alle vrijspraken zijn derhalve te wijten aan een slechte voorbereiding van de politie. Desalniettemin baart het grote aantal vrijspraken grote zorgen. Uit het jaarversilag van de CPS van 1990-1991 komt mat voren dat het aantal wrijspraken sinds de oprichting van de CPS echter niet noemenswaardig afgenomen is. CPS, 1991; Lensing, 1991, p. 1048-1077; Zander, 1988, p. 208; Zander, 1991, p. 256 e.v.

484. Zo'n 31 politiekorpsen beschikten over een prosecution solicitors deparment. die in rechte namens de politie optrad. Tak, 1988, p. 26.

485. Het feit dat verschillende instanties tot vervolging over kunnen gaan, is hier debet aan. Tak, 1988, p. 31-32.

486. Tak, 1988, p. 32.

487. Report of the Royal Commission on Criminal Procedure 1981, 1981, para. 7.25.

488. Bennion. 1986, p. 6-7.

489. Opsporingsbevoegdheden zouden bij de politie blijven liggen. Het misbruik van de bevoegdheden door de politie in de zaken van Guildford Four, Maguire Seven en Birmingham Six heeft tot gevolg gehad dat men zich afvraagt of vervolging en opsporing toch miet in handen van ë́n dienst moeten komen. Op deze vraag wordt later in dit verhaal aandacht besteed. Report, 1981, par. 7.7. 
handen zou hebben en waar aan het hoof een crown prosecutor zou staan. ${ }^{400}$ De hoofdcommissaris en de crown prosecutor zouden beide verantwoording moeten afleggen aan een nog op te richten Police and Prosecution Authority. ${ }^{493}$ Het voordeel van een regionale vervolgingsinstantie zou zijn dat samenwerking met de lokale politiekorpsen gemakkelijker te bereiken zou zijn. ${ }^{492}$ In eerste instantie wist de regering Thatcher niet hoe deze woorstellen in de praktijk te brengen. De regering was niet zozeer te spreken over een regionale organisatie van een CPS. Daarom werd in 1982 een werkgroep On Prosecuting Arrangements benoemd met het doel na te gaan hoe de voorstellen in de praktijk verwezenlijkt zouden moeten worden. Met name werd de werkgroep gevraagd na te gaan wat de uitwoerbaarheid was van drie modellen van vervolgingsinstanties ${ }^{493}$ :

a) nationaal model,

b) gedecentraliseerd nationaal model of

c) regionaal model.

De werkgroep opteerde voor het nationaal model. De werkgroep kwam in 1983 tot de conclusie dat een systeem waarbij los van de politie op nationaal niveau een vervolgingsinstantie werd opgericht, onafhankelijk van de politie, verantwoordelijk, kostenbesparend en effectief zou zijn en bovendien tot uniformiteit in het vervolgingsbeleid zou leiden. ${ }^{494}$ Op grond van het rapport van de werkgroep werd in november 1984 een wetsvoorstel ingediend in het parlement.

490. Volgens Schalken zijn bovendien de recente wrijspraken van 0.a. de Guildford Four en de Birmingham Six mede aanleiding geweest voor de oprichting van de CPS. De oprichting van deze dienst dateert echter van vóx het heropenen van deze zaken woor de Crown Court. Deze reden voor de oprichting van de CPS moet derhalve van de hand worden gewezen. Schalken, 1991, p. 193.

491. Wood, in: Hall Williams, 1988, p. 19-20; Zander, 1988, p. 210-211.

492. In The Police: powers, procedures and proprieties, onder redactie van Benyon en Bourn, 1986, wordt uitgebreid op deze materie ingegaan.

493. White, 1986, p. 200.

494. The Organisation of an Independent Prosecution Service, Report of the Working Party on Prosecution Arrangements, HMSO, London, 1983, Cmnd 9074; Zander, 1988, p. 212; Tak, 1988, p. 34.

Tegenstanders van een nationaal vervolgingsorgaan beweren daarentegen dat. 1) het gevaarlijk is de beslissing over vervolgingen te concentreren in één functie, 2) een nationaal systeem bureaucratie in de hand werkt, 3) lokaal vervolgingsbeleid onmogelijk maakt en 4) in strijd zou zijn met de traditie. White, 1986, p. 203. 


\subsection{Prosecution of Offences Act 1985}

In 1986 is de Prosecution of Offences Act 1985 in werking getreden. ${ }^{\text {as }}$ Deze wet vestigde één nationaal: vervolgingsinstinut onder leiding van de Director of Public Prosecutions ${ }^{\sharp 5}$. De wet verdeelde het land in 31 gebieden: 29 in Engeland en twee in Wales. Dertien gebieden in Engeland en een gebied in Wales komen overeen met de grenzen van bestaande politiekorp$\operatorname{sen}^{497}$ De rest van de gebieden is samengesteld wit ieder twee bestaande politiekorpsen. ${ }^{498}$ In elk gebied, het District Head Office, staat een chief crown prosecutor aan het hoofd, die aan de DPP werantwoording verschuldigd is. Een Police and Prosecution Authority die de bestaande politiecommissie zou moeten vervangen, is er niet gekomen.

\subsection{Taken van de CPS}

De Crown Prosecution Service (CPS) neemt alle strafzaken van de politie over tegen volwassenen en jeugdigen waarin niet is geseponeerd of geen waarschuwing (caution) is gegeven. Is een zaak eenmaal door middel van sepot of caution door de politie afgedaan, dan bestaat er geen mogelijkheid voor de CPS de zaak alsnog te vervolgen. Wel geeft de wet de DPP het recht zelf gerechtelijke stappen te ondernemen tegen bepaalde misdaden. ${ }^{499}$ Hierbij moet gedacht worden aan zaken als abortus, hoogverraad, strafbare feiten waar de doodstraf op staat en andere feiten die in een lijst vermeld staan en verspreid zijn onder politiekorpsen en lokale parketten. Bij de vervolging van enkele strafbare feiten is zelfs expliciet de toestemming vereist voor een vervolging.

495. In de counties Greater Manchester, Merseyside, South Yorkshire, Tyne and Wear, West Midlands, West Yorkshire, Durham en Northumbria geschiedde dit in april 1986. In oktober 1986 werd de wet in London en de rest van Engeland en Wales van kracht. Deze regeling bracht met zich mee dat tussen april en oktober 1986 twee verschillende vervolgingssystemen gebruikt werden in Engeland en Wales. Zander, 1988, p. 213; Prosecution and Offences Act 1985, The Law Society's Gazente, 9 April 1986, p. 1029.

496. De standplats van de Director is Londen.

497. Bennion, 1986, p. 10.

498. Londen vormt ook hier een uitzondering. De stad is in drie gebieden verdeeld: inner London, north London en south London and Surrey. Gandy, 1988, p. 8.

499. Art. 8 Prosecution of Offences Act 1985. 


\subsubsection{Taken wan de DPP}

De functies van de Director of Public Prosecutions staan omschreven in artikel 3 van de Prosecution of Offences Act 1985. ${ }^{500}$ De volgende taken kunnen onderscheiden worden:

- $\quad$ strafzaken van de politie over te nemen en voort te zetten;

- bepaalde strafbare feiten vanwege hun aard, belangrijkheid of moeilijkheid te vervolgen;

alle zaken over te nemen die in relatie staan met de Obscene Publications Act 1959;

- advies te geven aan politiekorpsen over zaken die strafbare feiten betreffen;

- $\quad$ in alle hoger beroepszaken als wervolgingsinstantie te fungeren en

- alle andere taken vervullen die hem door de Attorney General van tijd tot tijd toegewezen worden.

In art. 6 Prosecution of Offences Act 1985 krijgt de DPP de bevoegdheid een door een burger of inslantie aangevangen vervolging over te nemen. Indien in een dergelijk geval de zaak al aan de rechter is voorgelegd, dan kan de $D P P$ niet meer tot een sepot besluiten.

\subsubsection{Bevoegdheden van de prosecutors}

In de Magistrates" Courts mogen de prosecutors optreden: In de hogere rechtbanken zoals de Crown Court niet; daar moet de CPS vertegenwoordigd zijn door een barrister. Als argument hiervoor wordt aangevoerd dat crown prosecutors niet onafhankelijk en onpartijdig genoeg zouden zijn, maar externe barristers wel. ${ }^{501}$ In artikel 23 Prosecution of Offences Act 1985 wordt de bevoegdheid gegeven de vervolging in een procedure in een Magistrates' Court te staken, in die gevallen dat de bewijsmiddelen nog niet naar voren zijn gebracht. Deze bewoegdheid is in de wet expliciet aan de DPP gegeven. Echter, de Prosecution of Offences Act 1985 heeft aan de prosecutors dezelfde bevoegdheden gegeven als aan hun baas, de DPP. ${ }^{502}$ Dit betekent dat zij nu ook de mogelijkheid hebben een zaak tussentijds te beëindigen. Prosecutors oefenen hun functie wel uit onder leiding van de DPP. Als eenmaal in een rechtszaak de bewijsmiddelen naar voren zijn

500. Zie ook White, 1988, p. 201.

501. Over de vraag of crown prosecutors ook in de crown court zouden mogen optreden en de relatie tussen barristers en prosecutors zie: Gandy, in: Hall Williams, 1988, p. 8; Lensing, 1991, p. 1048-1077; Hill, in: Benyon en Bourn, 1986, p. 237-242; en het interview met Alastair Logan in de bijlage.

502. Artikel 1. Prosecution of Offences Act 1985. 
gebracht, is artikel 23 niet meer van toepassing. Wil een prosecutor dan toch nog een zaak tussentijds staken, dan kan hij aan de rechters meedelen dat hij de zaak wil intrekken en de rechters verzoeken de verdachte te laten gaan. ${ }^{503}$

\subsection{De situatie vóór de Prosecution of Offences Act 1985}

Vóór 1986 had de politie nagenoeg het alleenrecht om te vervolgen voor het begaan van strafbare feiten. ${ }^{504}$ De politie onderzocht zaken en besloot of een persoon in staat van beschuldiging gesteld moest worden. Daarna bekeek de politie of er reden was tot (verdere) vervolging. Aangezien lang niet alle agenten juridisch geschoold waren, maakten zij bij enkele beslissingen en bij het aanbrengen van de zaak bij de rechtbanken gebruik van de hulp van solicitors en barristers ${ }^{505}$. Deze prosecuting solicitors of barristers moesten de instructies van de politie opvolgen. Politie en vervolgingsinstantie waren niet onafhankelijk van elkaar. ${ }^{506}$

Vóór 1986 kon een vervolging op vijf verschillende manieren ${ }^{507}$ plaatsvinden:

1) De meeste zaken werden aangebracht door de politie. Tot 1986 waren Engeland en Wales één van de weinige gebieden ter wereld waar de vervolging van het grootste aantal strafbare feiten aan de politie overgelaten werd. Alle korpsen hadden een eigen vervolgingsbeleid, waardoor grote verschillen konden bestaan in het beleid tussen de verschillende korpsen ${ }^{508}$ De meeste korpsen hadden binnen hun korps een afzonderlijke dienst van prosecuting solicitors gecreëerd. Andere korpsen schakelden solicitors buiten het korps in om bepaalde zaken te vervolgen.

2) De law officers, waaronder verstaan worden de Attorney-General en zijn medewerker, de Solicitor-General, hadden (en hebben) twee functies bij de vervolging van strafbare feiten. De Attorney-General kan bij een aantal zaken zijn goedkeuring geven of weigeren om een

503. Timmons, 1986, p. 29.

504. Alleen de ernstige zaken werden door de Director of Public Prosecutions behandeld: zie verder.

505. Magistrates" Court respectievelijk Crown Court.

506. Sanders, 1986, p. 16.

507. Zander, 1988, p. 204-205.

508. Onwillekeurig zal het vervolgingsbeleid toch op elkaar zijn afgestemd. Waar het hier om gaat is dat er geen van boven opgelegde 'Richilijn woor het vervolgingsbeleid" was. 
vervolging te beginnen. Tevens heeft de Attomy-General de bevoegdheid een zaak in de Crown Court te beểindigen (nolle prosequi).

3) De DPP had een verplichte taak tot vervolging in alle gevallen waarop de doodstraf stond (deze taak is verouderd, aangezien de doodstraf in Engeland en Wales afgeschaft is), in zaken, hem vonrgelegd door diensten van de regering en in "any other case whick appears to him to be of importance or difficulty or which for any other reason requires his intervention'. ${ }^{509}$ Voor een substantieel aantal zaken is de toestemming van de Director of Public Prosecutions vereist om te kunnen vervolgen. "A refusal of such consent is in effect an onder not to prosecute and to this extent it may be said that the Director is able to control the Commissioner and Chief Constables in the exercise of their duty to enforce the law." 510

4) Regeringsdepartementen, industrieên, lokale overheden en andere openbare lichamen namen een aanzienlijk deel van de vervolgingen voor hun rekening. $s_{11}$

5) Burgers konden een procedure starten, ook als zij geen direct belang bij de vervolging hadden. De $D P P$ kon de vervolging overnemen en de Attorney General kon door middel van een nolle prosequi een procedure stop zetten. ${ }^{512}$

De Royal Commission on Criminal Procedure vond het een gemis dat de Director niet over de mogelijkheid beschikte om richtlijnen uit te vaardigen aan prosecutors. Richtlijnen over algemene vervolgingsbeginselen, die door alle prosecutors gevolgd zouden worden, zou de consistentie in opsporing en vervolging in Engeland en Wales ten goede komen. ${ }^{513}$ In 1983 had de Attomey-General al criteria (Criteria for Prosecution) bekendgemaakt voor de vervolging van strafbare feiten. Dit was voor het eerst dat officiële criteria vastgesteld werden voor het nemen van de beslissing al dan niet tot vervolging over te gaan. Dit geschiedde vooruitlopend op de zeer waar schijnlijke totstandkoming van een nationaal vervolgingsinstituut. Deze criteria hadden zowel betrekking op prosecutors als op diensten, bedrijuen

509. Zie de Prosecution of Offences Act 1946, Regulation 1.

510. Card, 1979, p. 13.

511. Ongeweer eenvierde deel van alle vervolgingen.

De Engelse PTT vervolgt bijwoorbeeld vanwege het niet betalen van de kijk- en luistergelden, de British Transport Police vanwege het zwart rijden en de Department of Health and Social Security vanwege de sociale (bijstands-) fraude. Zander, 1988, p. 205; zie voor andere voorbeelden Tak, 1988 , p. 27.

512. De bevoegdheid van burgers en instantiss (punten 4 en 5 ) orn zelfstandig een procedure te beginnen is niet gewijzigd door de Prosecution of Offences Act 1985.

513. Bennion, 1986, p. 9; Zander, 1988, p. 210. 
en burgers die een zaak voor de rechter willen brengen. ${ }^{514}$ Ook de DPP had in 1986 criteria openbaar gemaakt met het oog op de inwerkingtreding van de Prosecution of Offences Act $1986 .^{515}$ Dit komt overeen met de inhoud van artikel 10 van de nieuwe wet die de Director verplicht een Code for Crown Prosecutors op te stellen voor zijn crown prosecutors, waarin algemene richtlijnen opgenomen moeten worden betreffende het vervolgingsbeleid. ${ }^{516}$ Beslissingen van de lokale kantoren van de CPS moeten in overeenstemming met de richtlijnen genomen worden.

Vanaf 1986 beslist de politie niet meer over verdere vervolging. Dat doet sinds 1986 de CPS. De politie bezit nog wel de bevoegdineid om bij een ontdekking van een strafbaar feit de zaak al dan niet zodanig te classificeren. De politie behoudt derhalve de mogelijkheid een zaak te seponeren of met een waarschuwing af te doen. ${ }^{517}$ Deze vorm van discretionaire bevoegdheid is niet of nauwelijks te controleren. Wat dat betreft is het niet slecht dat een onafhankelijke dienst nu gaat bekijken of zaken een verdere vervolging nodig hebben. ${ }^{518}$ De Attorney-General heeft het recht in de Crown Court te allen tijde een zaak te beëindigen door middel van de nolle prosequi. ${ }^{519}$ Van dit recht kan in de Magistrates" Court geen gebruik worden gemaakt. Voor het gebruik wan dit recht is de Attomey-General verantwoording verschuldigd aan het parlement. De Attomey-General gebruikt deze bevoegdheid bijna nooit. ${ }^{\$ 20}$

514. Samuels, 1986, p. 39; zie ook Sanders, 1985, p. 4.

515. Zander, 1988 , p. 224.

516. Volgens de richtlijnen zou steeds nagegaan moeten worden of er voldoende bewijs voorhanden is, teneinde een realistic prospect of conviction te bewerkstelligen. Dit zou kunnen voorkomen dat er te veel vrijspraken gegeven worden. Daarnaast o.a. moeten politie en prosecuror bekijken of een vervolging in het algemeen belang is. Is de prosecutor ook dan nog niet zeker over een veroordeling, wordt bekeken hoe de gemeenschap tegenover het delict staat en hoe vaak het delict voorkomt in het gebied of het land. Code for Prosecutors, Law Society's Gazette, 23 July 1986, p. 2308; Bennion, 1986, p. 14; Sanders, 1985, p. 4-5; Williams, 1985, p. 115 e.v.; Koers, 1988, p. 101 .

517. De CPS kan de politie wel advies geven ower de vraag of tot een vervolging moet worden besloten. Tak, 1988, p. 35; Tak, Lensing, 1990, p. 67.

518. Sanders, in: Hall Williams, 1988 , p. 38 .

519. Als een persoon die terecht stat on lichamelijke of psychische redenen niet in staat wordt geacht terecht te staan, kan tot een nolle prasequi worden besloten. Dit heeft geen vrijsprak woor de verdachte tot gevolg, maar wel een indefinite adjoumment. De mogelijkheid blijft bestaan dat een nieuwe vervolging wordt ingesteld. Tak, 1988, p. 29.

520. Sanmels, 1986, p. 41; Jurisprudentie waar wel gebruik van het recht gemaakt is: Turner v. DPP (1978) 68 Cr. App. R. 70, Turner (1975) 61 Cr. App. R. 67 . 
Indien er een aanklacht tegen een persoon bestaat, gaat zijn dossier van de politie naar de Crown Prosecution Service, dat besluit of en op welke grond er vervolgd gaat worden. ${ }^{521}$ Het strafbare feit waarwoor een persoon vervolgd wordt kan dus verschillen van de aanklacht waarvoor diezelfde persoon gearresteerd is. Ook is het mogelijk dat de prosecutor een persoon slechts een berisping zal geven of niet tot vervolging will overgaan omdat naar zijn mening het bewijs niet toereikend is. Wat dit punt betreft, bevat de huidige procedure derhalve een middel om de politie te controleren op haar opsporingsbeleid. ${ }^{522}$

\subsection{Opportuniteitsbeginsel}

De CPS is niet verplicht alle zaken die zij ontvangt van de politie te vervolgen; de dienst heeft derhalve een sepot-bevoegdheid. De CPS en de politie gaan uit van het opportuniteitsbeginsel. In de Prosecution Guidelines van 1983 wordt gesteld dat de prosecutors tot vervolging over kunnen gaan als dat in het openbaar belang vereist zou zijn. Rechterlijke controle op dit opportuniteitsbeginsel vind nauwelijks plaats. In het verleden heeft de heer Blackburn wel getracht een rechterlijk oordeel te krijgen over politieoptreden, maar ook hier werd de onafhankelijkheid van de politie erkend. ${ }^{523}$

\subsection{Een onafhankelijke Crown Prosecution Service?}

Het parlement wilde dat de CPS onafhankelijk zou zijn van de politie. De crown prosecutors zijn als gevolg daarvan allemaal ambtenaren (civil servants). De dienst heeft de verantwoordelijkheid ervoor te zorgen dat onbenullige of slecht voorbereide zaken niet meer voor de rechters komen. Dit houdt in dat zij de zaken die aangebracht worden door de politie opnieuw onafhankelijk moet beoordelen. ${ }^{524}$ Toch blijft de vraag bestaan of de CPS wel echt onafhankelijk zal kunnen functioneren. ${ }^{525}$ Een voordeel dat een

521. De politie behoudt desalniettemin het recht om zaken zelfstandig bij de rechters aan te brengen. Timmons, 1986, p. 32.

522. Zie bijvoorbeeld Sanders, in: Hall Williams, 1988, p. 30; zie ook Ashwonth, 1985 , p. $1-2$.

523. Tak, Lensing, 1990, p. 67

524. Timmons, 1986, p. 28.

525. Roger Tarling gaat in zijn artikel bijwoorbeeld na wat de gevolgen van de oprichting van de nieuwe Crown Prosecution Service zijn voor de opsporingscijfers van de politie, voor het aantal verdachten dat uiteindelijk tot een gevangenisstraf veroordeeld wordt en voor vertragingen bij de rechters. Hij probeert aan te tonen dat de oprichting wan de CPS weranderingen teweeg zal brengen binnen het gehele strafrechtsysteem. Daarmee geeft hij aan dat alle dicnsten binnen de strafrechtstelsel onderling afhankelijk van elkaar zijn. Tarling, 1988, p. 43-50. 
onafhankelijk vervolgingsinstituut met zich mee zou brengen was, dat er een grotere eenheid in het vervolgingsbeleid zou komen. Het onafhankelijkheidsvraagstuk zal ik hieronder trachten te behandelen.

De beslissing om in een zaak tot een vervolging over te gaan lag vroeger in handen van de politie. ${ }^{526}$ Ook nu nog beslist de politie zelfstandig of zij een zaak al dan niet doorstuurt voor verdere vervolging, waarover de CPS uiteindelijk het besluit neemt. Is een zaak doorgestuurd, dan krijgen de prosecutors de bevoegdheid zich verder met de zaak bezig te houden. Indien de prosecutors een verdergaand onderzoek nodig achten, hebben zij de hulp van de politie nodig. Wat dat betreft is de CPS afhankelijk van de politie. Het instituut beeft niet de mogelijkheid zelfstandig onderzoek te verrichten. De prosecutors, in tegenstelling tot de Officier wan Justitie in Nederland, kunnen de politie niet bevelen een bepaald onderzoek te verrichten; ze kunnen de politie slechts verzoeken dit te doen. ${ }^{527}$

Schema

\begin{tabular}{|c|c|c|c|c|c|}
\hline Voör & Pollitie- & Forensics & Rechter & \multicolumn{2}{|c|}{ Beroepsinstanties } \\
\hline $\begin{array}{l}\mathrm{Na} \\
1986\end{array}$ & $\begin{array}{l}\text { Politie- } \\
\text { onder- } \\
\text { zoek }\end{array}$ & Forensics & $\begin{array}{l}\text { CPS: verwijst de zalk } \\
\text { eventueel terug naar de } \\
\text { politie voor nader onder- } \\
\text { zoek }^{522} \text { en geeft advies }\end{array}$ & Rechter & $\begin{array}{l}\text { Beroeps- } \\
\text { instanties }\end{array}$ \\
\hline
\end{tabular}

De nieuwe Prosecution of Offences Act 1985 heeft de crown prosecutors toch twee middelen in handen gegeven om te zorgen dat er een zekere mate van consistentie ontstaat zowel in het opsporingsproces als in thet beslis. singsproces van de politie om zaken door te sturen. De prosecutors mogen de politie te allen tijde vrijblijvend adviseren zowel in het algemeen als in het bijzonder. ${ }^{529}$ Daarnaast hebben de prosecutors de bevoegdheid een vervolging te beeindigen, indien deze zaak nog niet aan een rechter is voorgelegd. ${ }^{530}$ Dit houdt in dat de politie de zaak nog niet naar de rechters heeft doorgestuurd.. ${ }^{5 i n}$

526. Behalve dan in die gevallen dat voor een vervolging de toestemming van de $D P P$ vereist was.

527. Zander, 1988, p. 213.

528. Het zou voor de IRA-zaken (zie het volgende hoofdstuk) waarschijnlijk beter zijn geweest als er toentertijd een CPS geweest was. De CPS staat minder onder druk van de samenleving om verdachten naar voren te schuiven en te vervolgen.

529. Artikel 3(2) van de Prosecution of Offences Act 1985.

530. Artikel 23 Prosecution of Offences Act 1985

531. Sanders, 1986, p. 18. 
Willen deze middelen echter effectief zijn, dan wordt van de politie verwacht dat zij openstaat voor dergelijk advies. De politie moet bereid zijn zaken te laten zien aan prosecutors en daarnaast nog zo bereidwillig zijn orn het advies van de prosecutors op te volgen. Sanders betwijfelt of de politie in deze mate samen zal willen werken met de CPS. ${ }^{532} \mathrm{Hij}$ is van mening dat de prosecutors op deze manier afhankelijk zijn van de goede intenties van de politie. Indien een politieagent wil dat een zaak per se vervolgd zal worden - ook al is het een zaak waarvoor wellicht onvoldoende bewijsmiddelen zijn - zal hij het dossier doorsturen naar de rechtbank ter verdere afhandeling, zonder (een negatief) advies van de prosecutors te vragen.

Ook wat de opsporingsfase betreft, verwacht Sanders niet dat de nieuwe wet tot een verhoogde mate van consistentie komt. Een prosecutor zal niet gauw door een agent geconsulteerd worden over zaken, waar de agent normaal met een waarschuwing volstaat. ${ }^{533}$ In deze fase zal de politieagent over het algemeen vast willen houden aan zijn eigen handelwijze.

\subsection{Verhouding politie-prosecutor}

In het bovenstaande hebben we gezien dat de politie, ondanks de nieuwe wetgeving, vrij zelfstandig kan blijven functioneren. Voor de vervolging van strafbare feiten blijken politie en prosecutors elkaar nodig te hebben. Wat dat betreft hebben zij hetzelfde doel voor ogen. ${ }^{534}$ Ook zagen we dat de prosecutors \ang niet zo onafhankelijk van de politie zijn, als dat met de wetgeving gepoogd was te bereiken. De CPS heeft de politie bij een onderzoek nodig; de politie maakt in eerste instantie uit welke zaken vervolgd worden en welke zaken met een waarschuwing kunnen volstaan of geseponeerd worden. In feite kan wel gesteld worden dat het gehele onderzoek door de politie uitgevoerd wordt. De politie houdt derhalve in zekere zin de macht over het verivolgingsproces. ${ }^{535}$ De Royal Commission on Criminal Procedure had voor ogen gehad dat de CPS het werk van de politie onder toezicht zou houden en controleren. In de praktijk is dat echter niet te doen. Een heel eenvoudige reden hiervoor is dat het CPS nu eenmaal niet genoeg personeel heeft. Al vanaf het begin van de oprichting van de CPS kampt de dienst met personeelstekorten. ${ }^{536}$ Een gevolg hiervan is dat de prosecutors die de status hebben van ambtenaar, veel werk hebben en derhalve veel moeten overwerken. Dit maakt de baan niet aantrekkelijk voor zowel solici-

532. Sanders, 1986, p. 18.

533. Sanders, 1986, p. 19.

534. Zie ook Timmons, 1986, p. 30; Tarling, in: Hall Williams, 1988, p. 43-50.

535. Sanders is van mening dat de invoering van een CPS weinig of geen verandering zal teweegbrengen in het systeem. Sanders, 1986, p. 26-27.

536. Koers, 1988, p. 101 . 
tors (die dus bijna niet op deze banen solliciteren) als woor de crown prosecutors zelf (die massaal ontslag nemen). Tot nu toe maakt de CPS, vanwege het personeelstekort, naast de eigen prosecutors gebruik van de hulp van solicitors, die tijdelijk meehelpen strafbare feiten te vervolgen. De solicitors krijgen daarbij dezelfde bevoegdheden als de prosecutors. ${ }^{537}$

Afgezien van bovengenoemd punt, lijkt het niet waarschijnlijk dat de CPS het werk van de politie zou gaan nalopen. Het ligt meer voor de hand dat de prosecutors op gelijke wijze als voorheen ${ }^{538}$ met de politie zullen samenwerken, in die zin dat de prosecutors de zaken van de politie gewoon overnemen en voortzetten zonder vorm van controle. Voor hun werk is een goede samenwerking vereist met de politie. ${ }^{\$ 391}$ In de eerste jaren van de CPS werd vooral door de politie met argusogen naar de CPS gekeken. De $C P S$ werd als een indringer beschouwd, die het werk van de agenten zou gaan controleren en gedeeltelijk zou gaan afpakken. ${ }^{540}$ De pollitie heeft erg moeten wennen aan de CPS. De CPS komt de politie tegemoet door in individuele zaken feedback te geven. Indien een prosecutor een strafzaak voortijdig wil beëindigen, wordt van te voren de mening gevraagd van de agent die de zaak voor verdere verwolging doorgestuurd had naar de prosecutor. Volgens de politie stelt de CPS hoge eisen aan het bewijsmateriaal. ${ }^{541}$ Van de zijde van de CPS komt de klacht dat de politie dossiers vaak pas op het laatste moment doorsturen naar prosecutors die dan niet goed voorbereid op de strafzittingen verschijnen. ${ }^{542}$

Eigenlijk is het nog een beetje te vroeg om conclusies te formuleren over het handelen wan de CPS. De CPS heeft tijd nodig om door politie, rechters en burgers geaccepteerd te worden. Wel kunnen we concluderen dat de startfase van de CPS moeilijk verlopen is. Vanaf het begin had de dienst te kampen met werkachterstanden en weinig financiële middelen. In hoeverre de prosecutors onafhankelijk kunnen en zullen blijven, moeten we afwach$\operatorname{ten}^{543}$

537. Tak, 1988, p. 36.

538. Toen zij nog in dienst wan de politie zaken moesten aanbrengen voor de rechter.

539. Zander, 1988, p. 227

540. Visies van politieagenten staan verwoord in: West, 1986, p. 224-229, en Merricks, in: Benyon en Bourn, 1986, p. 243-250.

541. Hetgeen ik helemal geen probleem vind. Hoe meer bewijs, hoe meer kans op rechtvaardige rechtspraak. Brown, 1991, p. 78.

542. Lensing, 1.991, p. 1048-1077.

543. Zie ook Hall Williams in: Hall Williams, 1988 , p. 104-107; Sieghart, in: Hall Williams, 1988 , p. $95-103$. 
De Royal Commission on Criminal Justice heeft in haar rapport van 1993 aanbevelingen gedaan betreffende de vervolging van strafbare feiten. Het instellen van de commissie geschiedde naar aanleiding wan het vernietigen van vonnissen in IRA-zaken, zoals de Birmingham Six, Guildford Four en de Maguire Seven. In deze zaken hebben niet alleen de politieagenten, maar ook anderen (o.a. deskundigen en rechters ${ }^{544}$ ) 'fouten" gemaakt. Het bestaande systeem wordt niet meer in staat geacht miscarriages of justice $e^{545}$ tegen te gaan, zoals in bovengenoemde zaken gebeurd is. De commissie had tot taak de doelmatigheid wan het strafrechtsysteem aan een onderzoek te onderwerpen en voorstellen te doen voor wijzigingen van het bestaande systeem. ${ }^{546}$ Daarbij waren, hoewel in mindere mate, zowel de politie als de CPS eveneens onderwerp van onderzoek, aangezien de CPS impliciet een controlerende bevoegdheid heeft inzake het politie-optreden. De voornaamste aanbevelingen zijn dat de politie al in het onderzoeksstadium advies van de CPS moet vragen. Daarnaast zegt de commissie dat als een chief officer of police verzoeken van de CPS om een zaak nader te onderzoeken naast zich neerlegt, de HM Chief Inspector of Constabulary de chief officer kan opdragen het onderzoek wel uit te voeren. ${ }^{547}$

\subsection{Controle over de politie}

Hierboven is al aangegeven dat de Attorney-General, die deel uitmaakt van de regering, ter verantwoording geroepen kan worden voor en door het partement. Wat dit betreft staan het algemene vervolgingsbeleid en de efficiëntie van de vervolgingsinstanties sinds 1986 open voor controle van het parlement wat voordien niet het geval was. Het betreft hier steeds het algemeen beleid. Over individuele gevallen kan het parlement geen controle uitoefenen. Toch moet hierbij de opmerking worden gemaakt dat veeleer de CPS dan de politie gecontroleerd zal gaan worden. Immers het vervolgingsbeleid wordt ontwikkeld door de Director of Public Prosecutions. Een grote inbreuk op de onafhankelijkheid van de politie zal derbalve niet gauw plaatsvinden.

544. Zie het artikel wan Zuckerman, 1991, p. 492-500.

545. In het algemeen is er sprake van een miscarriage of justice, warneer een vonnis vernietigd wordt tengewolge van twijfel van schuid, nadat alle beroepsgangen al bewandeld zijn. Zie O'Cormor, 1990, p. 615-628, p. 616 .

546. Men wil beogen dat het systeem een betere waarborg biedt dat onschuldige personen miet veroordeeld worden en dat schuldige personen hun straf niet ontlopen. De gehele taakomschrijving van de commissie staat in: Royal Commission on Criminal Justice. The Criminal Law Review 1991, p. 489-491, p. 489; zie ook Forder en Steyger, 1991, 26, p. 1050-1055.

547. Royal Commission on Criminal Justice, 1993, p. 72.74. 
De vrijlating van de Zes van Birmingham etc. heeft veel vragen doen oproepen over het functioneren van het strafrechtsysteem. Zijn er in het parlement vragen gesteld aan de Attorney-General over het doen en laten van de politie inzake deze IRA-zaken? Heeft iets dergelijks consequenties voor de politie? In zekere zin wel, aangezien opnieuw een commissie (i.c. de Royal Commission on Criminal Justice) in het leven werd geroepen die ook naar het functioneren van de politie in het vooronderzoek moest kijken. Aan de ene kant betekent het instellen van een commissie uitstel van handelen, waardoor het mandaat verzwakt wordt, aan de andere kant kan een commissie toekomstige veranderingen voorbereiden hetgeen positief is. 


\section{Miscarriages of justice}

"There can be little doubt that in the United Kingdom a just werdict is reached in most cases. Whe also believe there is little doubr that when an unjust verdict is reached, it is very difficult to rectify in. ${ }^{548}$

\subsection{Inleiding}

In dit hoofdstuk wil ik enkele rechtszaken bespreken waarvan rechters na ruim tien jaar de uitspraken vernietigd hebben. Deze zaken zijn bekend geworden als miscarriages of justice, gevallen van rechterlijke dwalingen $^{549}$ In deze zaken volgde na vele jaren vrijspraak voor de veroordeelden. In de meeste van deze rechtszaken bleek het bewijsmateriaal waarop de verdachten weroordeeld waren, achteraf gezien niet te deugen. De rol van de politie bij het werzamelen en falsifiëren van dat bewijsmateriaal is cruciaal geweest voor de veroordelingen. Dat de politieagenten grote fouten gemaakt hebben en bovendien door hun superiors niet voor hun handelwijze op het matje zijn geroepen, roept allerlei vragen op die betrekking hebben op de controle over het justitiële opsporingsapparaat. Al deze zaken hebben tot gevolg gehad dat de politie aan een nader onderzoek is onderworpen. In enkele zaken is de politie zelfs als verdachte van het vervalsen van bewijsstukken verwolgd. Helaas heeft dat tot nu toe geen consequenties inzake rechterlijke veroordelingen voor de politie gehad. ${ }^{559}$ Wel hebben deze zaken ertoe geleid dat ook naar andere gevallen is gekeken waarin verdachten tot jarenlange gevangenisstraf werden veroordeeld. Wat dat betreft hebben de hieronder behandelde zaken een sneeuwbaleffect teweeggebracht. ${ }^{551}$

548. JUSTICE Miscarriages of Justice, London, 1989, p. 73.

549. O'Connor geeft de volgende definitie van een miscarriage of justice: "... where a comiction has to be quashed because of a recognition of a reasonable doubt about guilt, at some stage after the normal avenues of appeal have passed or been exhausted." 1990, p. 616. Walker, 1993, p. 2: "A "miscarriage" means literally a failure to reach an intended destination or goal. A miscarriage of justice is therefore, mutadis mutandis, a failure to attain the desired end result of "justice"." 1993, p. 4: "A miscarriage occurs as follows: whenever individuals are treated by the State in breach of their rights; whenever individwals are treated adversely by the State to a disproportionate extent in comparison with the need to protect the rights of others; or whenever the rights of others are not properly protected or vindicated by State action against wrongdoers."

550. Zie bijwoorbeeld The Independent van 20 May 1993, p. 1,2 en 25: 'Detectives cleared over Guildford Four charges'. Zie ook Rose, 1996, p. 297-298, 299 301.

551. Dit geldt ook voor de verdediging, die elke gelegenheid te baat zal nemen om de onrechtmatigheid van de bewijsverkrijging aan te tonen. 
De zaken, die ik hier behandel, betroffen allemaal leren die veroordeeld waren voor het plegen van bomaanslagen en/of voor het in bezit hebben van explosief materiaal. De IRA had in de meeste gevallen schriftelijk of telefonisch de verantwoordelijkheid voor de bomaanslagen opgeëist. Ik heb onderstaande IRA-zaken ${ }^{\text {s2 }}$ uitgekozen, omdat deze zaken - maast het feit dat ze veel publiciteit gekregen hebben - uitvoerig aan de orde zijn gekomen in het parlement, wat het criterium is dat ik voor alle casus in deze studie heb gebruikt. Daarnaast hebben zij ook in Nederland veel verontwaardiging opgeroepen. ${ }^{553} \mathrm{Al}$ deze zaken zijn extreem. Zij laten naar mijn mening duidelijk zien waartoe ongecontroleerd politie-optreden kan leiden. ${ }^{554}$ Dit hoofdstuk will ik begimnen met een korte inleiding op een viertal zaken: Guildford en Woolwich, Maguire, Birmingham en Judith Ward ${ }^{55}$. Deze zaken speelden zich allemaal af in een relatief gezien kort tijdsbestek te weten van september 1973 tot december 1974. Aangezien de Maguire-zaak nauw verwant is aan de Guildford-en Woolwich-zaak heb ik deze direct na elkaar behandeld. Na de beschrijving van de vier zaken bespreek ik de kritiek, het gedrag van de politie, de rechtsgang, de gevolgen en de Royal Commission on Criminal Justice.

552. Als verzamelwoord noem ik deze zaken 'IRA-zaken', omdat in deze zaken bomaanslagen door de IRA gepleegd waren. Hiermee wil ik niet beweren dat de veroordeelden lid van de IRA waren. In de meeste gevallen waren zij geen lid van de IRA, al was de politie ten tijde van het plegen van de aanslagen wel de mening toegedaan dat zij op het minst banden met de IRA hadden. In bepaalde pubs in steden met een grote lerse bevolking werd geld bijcen gebracht voor politieke en humanitaire acties in Noord-Ierland. Over het algemeen nam men aar dat met dat gelld wapens voor de IRA werd gekocht.

553. In Roermond heeft xich enkele jaren geleden mamelijk ook een IRA-aanslag voorgedaan, en juist in de periade dat in Engeland het hoger beroep diende in enkele IRA-zaken.

554. Om echter te beweren dat soortgellike zaken hier niet zouden (kunnen) voorkomen, is een voorbarige stelling. Het boek van Crombag, Van Koppen en Wagenaar laat zien dat ook aan het Nederlandse rechtssysteem haken en ogen zitten en dat mensen in de gevangenis terecht komen terwijl het bewijsmateriaal in feite niet geheel in orde is. Crombag, Van Koppen, Wagenaar, 1992. Leijten heeft over deze problematiek een stukje geschreven onder de titel 'Onze les uit de Zes van Birmingham. ", NRC Handelsblad 22/3/1991; zie ook O'Connor, 1990, p. 615: "No system of criminal justice is immunte from miscarriages of justice." We moeten derhalve niet enkel commentaar leveren op het Britse systeem, maar, met deze zaken in het achierhoofd, een kritische kijk hebben op ons eigen systeem.

555. Zie voor een overzicht ook: Rozenburg, 1992, p. 91-117. 


\subsection{De lerse zaken}

Midden jaren zeventig was de politie zeer gebrand op het vinden van verdachten van de vele bomaanslagen die gepleegd werden in Engeland. De bomaanslagen begonnen in de West Midlands, een streek in het midden van Engeland, omstreeks augustus 1973, en breidden zich langzaam uit over andere delen van Groot-Brittannië. ${ }^{556}$ De aanleiding voor de golf van bomaanslagen was de zogenaamde Bloody Sunday - 30 januari 1972 - toen tenminste dertien katholieken in Londonderry doodgeschoten werden door het Britse leger. ${ }^{557}$ In de West-Midlands was de politie niet in staat in alle gevallen verdachten te arresteren, al was bekend dat de IRA (het Ierse Republikeinse Leger) achter de bomaanslagen zat. Vanwege het grote aantal doden bij enkele van de bomaanslagen was de druk van de publieke opinie mede gezien de grote publiciteit in de media ${ }^{558}$ - zeer groot om de verantwoordelijken op te sporen. De burgers namen in enkele gevallen zelfs het recht in eigen hand. Huizen en bezittingen van Ieren in Engeland waren niet meer veilig. ${ }^{559}$ De gemeenschap was derhalve opgelucht toen de politie onder andere zes verdachten van de bomaanslagen in Birmingham had opge-

556. Overzicht van bomaanslagen in West Midlands, 1973-1974:

29/8/1973 Twee bommen in Solihull

30/8/1973 Drie bommen in Solihull

1-17/9/1973 Vijf bommen in Birmingham

$2 / 1 / 1974 \quad$ Twee bommen in Birmingham

4/2/1974 Bom in bus (de Judith Ward-zaak)

3/1974 Een bom

4/1974 Bommen in Birmingham, Wolverhampton, Walsall en Manchester

7/1974 Een golf van bommen in Birmingham

(5/10/1974 Guildford, Guildford Four)

(7/11/1974 Woolwich, Wbolwich-zaak)

7-20/11 Zeven bommen in o.a. Birminghan, Wolverhampton en Coventry

21/11/1974. Twee bormen in Birmingham (Birmingham Six)

Londen:

$10 / 9 / 1973 \quad$ Bomaanslag in Londen (Euston Railway Station)

(Bron: Mulliv, 1990, p. 244-250).

557. Deze Bloody Sunday moet onderscheiden worden val die van 1920. Zie over de achtergronden van de lerse kwestie o.a. Kelley, 1982; O'Beine Ranelagh, 1983.

558. De media zijn vaak dé manier om misstanden aan het licht te brengen. Daarnaast kunnen ze echter zo vol met vooroordelen zitten, dat zij juist miscarriages of justice uitlokken. Zie hierover Sedley, 1993, p. 3.

559. Niemantsverdriet, 1991 , p. 17. 
spoord ${ }^{560}$. Drie van hen legden ook binnen enkele dagen een bekentenis af. Dat allen sporen van mishandeling vertoonden, roept de vraag op in hoeverre dit bewijsmaterial mee mocht tellen tot de bewezenverklaring. ${ }^{56 !}$

\subsection{Guildford Four en Woolwich ${ }^{562}$}

\subsubsection{De veroordeling}

Op 5 oktober 1974 en op 7 november 1974 vonden er bomaanslagen plaats in respectievelijk Guildford en Woolwich, waarvoor Patrick Armstrong (25 jaar), Gerard Conlon (21 jaar), Paul Hill (21 jaar) en Carole Richardson (18 jaar) in oktober 1975 tot levenslang veroordeeld werden. ${ }^{563}$

De onrust onder de bevolking na deze aanslagen was groot. De politie in Londen hield een soort razzia in de stad waarbij zij 40 tot 50 mensen aanhield waarvan zij wist dat zij banden onderhielden met Ierland en sympathiseerden met het Ierse terrorisme. Onder het gebruik van geweld bekenden er vier, zij het dat zij alleen verklaarden wat de politie allang wist. ${ }^{564} \mathrm{De}$ enige bewijzen in deze zaak waren hun bekentenissen tegenover de politie. Ter zitting brachten zij naar voren dat deze bekentenissen op onrechtmatige wijze verkregen waren en dat zij alle vier over een alibi beschikten. Na de veroordeling verklaarden andere personen dat zijzelf en niet de Guildford Four verantwoordelijk waren voor de bomaanslagen. ${ }^{565}$ Deze andere personen, bekend onder de naam de 'Balcombe Street Four's66, vroegen in januari 1977 in hun strafzaak voor andere bomaanslagen waarom de politie hen niet ook de bomaanslagen van Woolwich en Guildford te laste had gelegd. ${ }^{57}$ Helaas is hier in de zaak zelf maar ook in de dag-en weekbladen weinig aandacht aan geschonken. Toch was deze verklaring voor de Vier van Guildford reden om in beroep te gaan, d.w.z. leave to appeal aan te

560. Zie verder,

561. Zie Mullin, 1990, p. 117.118, Forder/Steyger, 1991, p. 1051.

562. Zie over deze zaak de film 'In the name of the father' van Jim Sheridan (1994).

563. Zie ook 108, H.C. Deb., 6th Ser, kolom 736; 145, H.C. Deb., 6th Ser., written answers, kolom 8.

564. Interview met Alistair Logan, solicitor van de Guildford Four, op 14 mei 1993.

565. Dit was de Balcombe Street Unit. De Balcombe Street Unit was een sectie van de IRA, die in 1974 verscheidene bomaanslagen gepleegd had. De politie was hiervan op de hoogte. De cenheid was aangehouden en verhoord. Interview met Alistair Logar op 14 mei 1993; zie ook Logan, 1993, p. 9.

566. Deze vier personen worden genoemd op p. 4 van R. v. Armstrong, Richardson, Hill and Conlon, CA, 28 October 1977.

567. Kee, 1986. p. 253-255. 
vragen. ${ }^{568}$ De Court of Appeal verwierp echter hun verzoek, omdat de Vier verdacht werden het hof te misleiden. "We are sure that there has been a cunning and skilful attempt to deceive the Court by putting fonward false evidence. ${ }^{569}$ In plaats van vier daders, was het heel goed mogelijk dat de bomaanslagen in Woolwich en Guildford door zeven of acht mensen gepleegd waren. ${ }^{570}$ "So, you get the involvement of the establishment then, the judiciary behaved quite outrageously in relation to those offences. The appeal should have been allowed. ${ }^{571}$ En dit vanwege het feit dat er zeer gerede twijfel bestond dat de vier van Balcombe Street de bomaanslagen gepleegd hadden. De personen die beweerden de echte daders te zijn waren heel goed op de hoogte van alle details in die zaak.

\subsubsection{De vrijlating}

In 1987 kreeg het politiekorps van Avon and Somerset van de minister de opdracht bepaalde feiten in deze zaak opnieuw te onderzoeken. Op 16 januari 1989 verwees Home Secretary Hurd de zaak naar de Court of Appeal op basis van art. 17 van de Criminal Appeal Act 1968. Er zou nieuw bewijs zijn in de vorm van verklaringen wan twee nieuwe getuigen en van een deskundige. ${ }^{572}$ Het bleek bij de Court of Appeal dat agenten 'misleading evidence' hadden gegeven en dat de uitspraken om deze reden niet in stand

568. Het is in Engeland en Walies niet vanzelisprekend, zoals in Nederland, dat de verdachte en het OM in hoger beroep kumnen gaan. In veel gevallen is het vereist om toestemming aan de Court of Appeal te vragen teneinde in hoger beroep te gaan. Toestemming is niet nodig als er alleen een rechtsvraag gesteld wordt. Hoger beroep wan een uitspraak van een Magistrates" Court is meestal mogelijk. Toestemming van de Court of Appeal volgt alleen als er nieuw be" wijsmateriaal aanwezig is. Wordt de toestemming gegeven dan kan de Court of Appeal ofwel de zaak zelf afdoen, hetgeen inhoudt dat alleen het nieuwe bewijsmateriaal bekeken wordt, ofwel de zaak terugverwijzen naar de Crown Court met een jury, die de gehele zaak opnieuw bekijkt. Wil een verdachte daarna opnieuw dat een rechter naar zijn zaak kijkt dan moet hij een verzoek richten aan de minister: Home Secretary. De minister kan alsdan bekijken of er voldoende reden bestaat om de zaak naar het Court of Appeal te verwijzen. Zander, 1988 , p. 11-19, 520-526, 538-540, 552-558.

569. R. v. Patrick Armstrong, Carole Margaret Richardson, Paul Michael. Hill and Gerard Patrick Conlon, CA, 28 October 1977, nrs. 395/R/77, 5291/R/75, 472/R/77, 998/R/77 (ongepubliceerd), p. 43 .

570. R. v. Armstrong, Richardson, Hill and Conlon, CA 28 October 1977, p. 13, 41-42; Kee, 1986, p. 260.

571. Interview met Alistair Logan, solicitor van de Guildford Four, 14 mei 1993.

572. 145, H.C. Deb., 6th Ser., written answers, kolom 9-10. 
konden blijven. ${ }^{573}$ De Crown Prosecution Service vroeg het hof derhalve de uitspraken te vernietigen. ${ }^{574}$ op 19 oktober volgde een vernietiging van de uitspraken van de Guildford Four. ${ }^{\$ 75}$ Aangezien het volgens de rechters zo voor de hand lag dat de agenten in deze zaak met het bewijsmateriaal geknoeid hadden, is de zaak niet volledig ter sprake gekomen ter zitting. ${ }^{576}$ Het bewijs warop de vernietiging van de uitspraken berustte, hebben de Vier van Guidford nooit te zien gekregen. ${ }^{5 \pi}$

\subsubsection{De zaak tegen de drie agenten}

"To both sides, the release of the Guildford Four was Round One; Round Two was the prosecution of those accused of having framed them. For defenders of the Four the prosecution would be the acid test of whether British justice could face up to what had been done in its name. ${ }^{\text {s5: }}$

De vrijlating van de Vier van Guildford had twee gevolgen. Ten eerste werd vanwege deze beslissing van de Count of Appeal in 1989 door de Director of Public Prosecutions onderzocht of enkele agenten vervolgd zouden kunnen worden voor het geven van 'misleading evidence' ${ }^{579}$ De DPP kwam tot een positief oordeel. Echter pas in mei 1993 diende er een rechtszaak tegen een drietal agenten ${ }^{580}$ in de Old Bailey in Londen voor het vervalsen

573. Dit misleading evidence bestond daaruit dat agenten van de politie van Surrey de werklaringen van de vier verdachten in de Guildford zaak weranderd en aangepast hadden. De angepaste verklaringen had de politie overhandigd aan de $D P P$ en de rechters, als betroffen het de originele verklaringen. Dit werd niet toelaatbaar geoordeeld.

574. R. W. Armstrong, Richardson, Hill and Conlon, CA, 19th October 1989, nrs, 89/429/S, 89/430/S, 89/431/S en $89 / 432 / \mathrm{S}$ (ongepubliceerd), proceedings, p. I, 22: "It is therefore the Crown's considered wiew that the recent discovery in the Surrey Police files of the material I have analysed with your Lardships throws such doubs now upon the honesty and integrity of that part of the investigation which led to the confessions that it would not be righ for the Crown to contend that the canviction of any appellan was either safe or satisfactory."

575. R. v. Armstrong. Richardson. Hill and Conlon, CA 19th October 1989* judgment, p. 16; zie ook 158, H.C. Deb., 6th Ser. kolommen 278-280.

576. Op de zitting kwam naar voren dat agenten bewijs achtergehouden hadden in cen apart dossier: "Not to be disclosed to the defence". Dit betrof Conlon. Daarnaast waren er documenten vervalst die vooral betrekking hadden op Armstrong. Zie Bennett, 1993, p. 6.

577. The Independent, 20 May 1993, p. 2 en 25.

578. Biennett, 1993 , p. 5.

579. 158, H.C. Deb., 6th Ser., kolom 279.

580. Zie voor een uitgebreide bespreking Bennett, 1993, p. 3, 5-15. 
van een bekentenis tegen één van de Vier van Guildford. ${ }^{581}$ De verdediging had de zaak enige jaren kunnen uitstellen. Het blijft een vraag waarom slechts drie agenten vervolgd werden terwijl een veel groter aantal betrokken was bij de Guildford-zaak. ${ }^{582}$ Over het algemeen werd verwacht dat deze drie agenten vrijgesproken zouden worden van hetgeen hun ten laste werd gelegd. ${ }^{583}$ Niet omdat zij werkelijk onschuldig zouden zijn, maar omdat een veroordeling ernstige consequenties voor het politieapparaat zou hebben. De agenten kregen tijdens de zitting een voorkeursbehandeling. Bennett beschrijft hoe men in een politiekorps omgaat met agenten die voor de rechter moeten verschijnen:

"It is not unknown for policemen and women to land in the dock. But nost of whose who do are there for reasons of private corruption. There is a distinction in the police force between "bent for yourself" and "bent for the job". The first term speaks for itself; the second has to do with what Paul Condon, the new Metropolitan Commissioner, has called "noble cause corruption" - the breaking of rules by officers who are acting, not with the motive of gaining for themsel. ves, but out of an overdeveloped sense of loyalty to the job. "Noble cause corruption" occurs when the police have in custody a suspec: they are convinced is guilty but lack the evidence to prove it. In such circumstances officers may, in their aw words, "enhance", "firm up"," "embroider", "bolster" or "boost" the evidence, by inwenting verbal admissions... or planting incriminating evidence. Policemen who are "bent for themselves" are a disgrace to the force; those who are accused of being "bent for the job" deserve sympathy and understanding. ${ }^{994}$

De Vier van Guildford zijn in deze zaak niet als getuige gehoord. Tijdens de zitting probeerden de advocaten van de drie agenten de jury ervan te overtuigen dat de Vier van Guildford wel degelijk de ware schuldigen waren geweest van de bomaanslagen. ${ }^{585}$ Op de rol van de agenten bij het vervalsen of wijzigen van het bewijsmateriaal werd door de verdediging nauwe-

581. Te weten Patrick Armstrong. In deze rechtszaak ging het slechts om een enkele bekentenis. Zie o. a. The Independent, 19 May 1993, p. 3.

582. Hillyard, 1994, p. 75.

583. Dit heb ik geconcludeerd naar aanleiding van interviews met $M r$. A. Logan, solicitor, Mr. M. Mansfield, barrister, en Mr. C. Mullin. parlementslid. Zie de bijlage.

584. Bennett, 1993, p. 7. "If there is a tendency in certain quarters to suspect that ary Irishman accused of an IRA bombing is guilty, there is equally a tendency usually found in the same quarters - to believe that policemen accused of being bent for the job are innocent.' Bennett, 1993, p. 14.

585. Zie bijvoorbeeld Logan, 1993, p. 9; Bennett, 1993, p. 8. Zie ook Rose, 1996. p. 312: 'Unacceptably often, defence counsel will secure an acquittal by attempting to put the victim on trial." 
lijks ingegaan. ${ }^{586}$ In feite voerde de verdediging een tweede zaak tegen de Vier van Guildford. Op 19 mei 1993 werden de drie agenten door de jury" wrijgesproken. Deze uitspraak kan het gevaar met zich brengen dat twijfel bij de bevollking kan rijzen over de onschuld van de Guildford Four. ${ }^{587}$

'As the Daily Telegraph leader writer put it after the end of the detectives' trial, "the acquittal of the three ex-policemen ... suggests there are reasonable grounds for suspecting that two of the Gulldford Four, Mr Patrick Armstrong and Mr Gerry Conlon, might hove been guilty after all. This raises the disturbing possibility that the real miscarriage of justice occurred when they walked free. "This was becoming a propaganda war, and there was no room for musing over niceties such as the difficulty in reaching the standard of criminal proof. If the police were innocent, the Cuildford Four must be guilty. ${ }^{58:}$

Op grond van de uitspraak uit 1989 stelde Home Secretary Hurd een onderzoek in naar het proces van de familie Maguire.

\subsection{Maguire Seven}

Na de bomaanslagen in Guildford en Woolwich onderzocht de politie de woning van de familie Maguire. Patrick Conlon, één van de zeven personen die toen gearresteerd werden, is de vader van Gerard Conlon die gearresteerd was voor het plegen van de bomaanslagen in Guildford en Woolwich. Volgens de politie hadden twee van de verdachten in de Guildford-zaak verklaard dat zij het materiaal voor de bomaanslagen van Mrs. Maguire

586. In de zeventiger jaren heerste er een andere cultur in het politieapparaat, in de trant van "... there is nothing wrong with perjury committed by an honest police officer with good intentions." (citaat afkomstig van Mullin in Home Affarrs Committee, Policing, 24 March 1993, p. 26.) Paul Condon zegt hierover in Home Affairs Committee, Policing, 24 March 1993, p. 26: "I think that police officers talk of something which we call "noble cause corruption", the essence of which is that the end justifies the means and, of course, it does not and never can. ...If I go back 20 years there was very much a confessions culture where there was an extension of, if you like, "It"s a fair cop, guv". "In die tijd kwam dit fenomeen in meerdere gevallen voor, vandaar de door Condon gebnuikte term culture. Natuurlijk was dit alleen onder agenten bekend, waardoor over dit fenomeen weinig jurisprudentie bestaat. $\mathrm{Vgl}$. Niemantsverdriet, 1991, p. 17, 19 en Mullin, 1990, p. 220 e.v.

587. Hetzelfde kan gelden voor de Tonenham Three. Ook in deze zaak zijn agenten vervolgd on vrijgesproken. The Independent, 20 May 1993, p. 25; The Times, 20 May 1993, p. 1, 3; Zie ook Bennett, 1993, p. 15; Logan, 1993, p. 10; Bermett, 1993, p. 3, 15.

588. Rose, 1996, p. 297. 
hadden gekregen ${ }^{589}$ Explosief materiaal of materiaal waarmee explosieven gemaakt kunnen worden, werd tijdens de huiszoeking niet aangetroffen. Wel reageerden de handen van zes gezinsleden positief op een scheikundige test, precies alsof zij in aanraking waren geweest met nitroglycerine. Mrs. Anne Maguire reageerde als enige negatief op de nitroglycerine-testen. Wel werd pas na ruim een week nitroglycerine op plastic handschoenen gevonden die Mrs. Maguire gewoonlijk gebruikte. ${ }^{590}$ Deze handschoenen waren al vanaf het begin in handen van de politie geweest. Ondanks dit zeer magere en enige forensische bewijsmateriaal werd de familie toch vervolgd: de familie had zich zeer waarschijnlijk ontdaan wan de explosieven na de arrestatie van Gerard Conlon. ${ }^{591}$ Daarentegen bestaat het vermoeden dat de nitroglycerine-sporen naderhand op de handschoenen zijn aangebracht. De aanwezigheid van nitroglycerine-sporen op de handen van de overige zes zou te verklaren zijn door "contamination in the laboratory. ${ }^{.592}$

Op 4 maart 1976 werden Anne Rita Maguire (40 jaar), Patrick Joseph Maguire (43 jaar), William John (Sean) Smyth (38 jaar), Vincent John Patrick Maguire (17 jaar), Patrick Joseph Paul Maguire (14 jaar), Patrick Joseph O'Neill ( 35 jaar) en Patrick Joseph (Guiseppe) Conlon (52 jaar) veroordeeld op grond van art. 4 lid 1 van de Explosive Substances Act 1883. In dit artikel wordt o.a. strafbaar gesteld het in bezit of onder controle hebben van explosief materiaal (in dit specifiek geval dus nitroglycerine), zonder dat men aan kan tonen dat men het materiaal onder zich heeft voor een wettelijk toegestaan doel. De straffen varieerden tussen de 4 en 14 jaar gevangenisstraf. ${ }^{593}$

Op basis van een onderzoek, uitgevoerd door Sir John May in 1989, naar de omstandigheden die geleid hebben tot het proces van de Guildford Four en de Maguire Seven ${ }^{594}$, werd de zaak door de Home Secretary op 12 juli

589. R. v. Maguire and others, (1992), 2 All. E.R., p. 439.

590. Later onderzoek zou aantonen dat deze test niet geheel waterdicht was. Ook andere stoffen reageerden positief op de test. Daarnaast bestond nog het gevaar van contamination (besmetting). Zie bijvoorbeeld R. $\%$. Maguire and others, (1992) 2 All E.R., p. 447-450.

591. R. v. Maguire and others, (1992) 2 All. E.R. p. 439-440.

592. Interview met solicitor Alistair Logan op 14 mei 1993.

593. R. w. Maguire and others, (1992). 2 All. E. R., p. 434-435.

594. Dit is hetzelfde onderzoek dat door Mr. Hurd ingesteld was op 19 aktober 1989. (158, H.C. Deb., 6th Ser., kolom 279) In de loop van dit onderzoek had de vermaarde scheikundige Professor Th. Burns experimenten uitgevoerd om na te gaan of de aanwezigheid wan nitroglycerine op de handen en handschoenen wan de zeven niet een onschuldige oorcak hadden. Zic R. v. Maguire (1992) 2 All. 
1990 verwezen naar de Court of Appeal. ${ }^{595}$ Op 26 juni 1991 deed de Court of Appeal uitspraak in de zaak. ${ }^{596}$ Op dat moment was Patrick 'Guiseppe' Conlon echter al overleden ${ }^{5 \% 7}$ en waren de overige zes allemaal weer op vrije voeten omdat ze hun straf inmiddels al hadden uitgezeten.

De Maguire Seven hadden zes beroepsgronden. Eén daarvan omvatte de mogelijkheid dat de zeven onbewust en onschuldig de nitroglycerine op hun handen hadden gekregen. In het May-onderzoek had Professor Burns aangetoond dat handen sporen van nitroglycerine kunnen bevatten zonder ook maar ooit werkelijk in aanraking met nitroglycerine te zijn geweest. Vanwege het feit dat het hof de mogelijkheid van innocent contamination niet kon uitsluiten en dat dus de veroordelingen unsafe and unsatisfactory waren, werden de uitspraken vernietigd. ${ }^{598}$

\subsection{Birmingham Six}

Hugh Callaghan, Patrick Hill, Robert Gerard Hunter, Richard Mcllkenny, William Power en John Walker (in leeftijd variërend tussen de 28 en 44 jaar) werden op 15 augustus 1975 veroordeeld tot levenslange gevangenisstraffen voor het plegen van een tweetal bomaanslagen in Birmingham op 21 november 1974 waarbij 21 mensen om het leven kwamen. Deze bomaanslagen vonden precies 54 jaar na de Bloody Sunday in Dublin op 21 november 1920 plaats. ${ }^{399}$ Op 30 maart 1976 vroegen de zes verlof om in hoger

E.R. 439 en Sir John May, Interim Report on the Maguire Case: Return to an Address of the Honourable the House of Commons dated 12 July 1990 for the Inquiry into the Circumstances Surrounding the Convictions arising out of the Bomb Attacks in Guildford and Wbotwich in 1974, H.C. 556, H.M.S.O., July 1990. Het eindrapport verscheen op 3 december 1992. 215, H.C. Deb., 6th Ser. written answers, kolom 335.

595. 176, H.C. Deb., 6th Ser, kolom 436.

596. 193. H.C. Deb., 6ih Ser, writen answers, kolom 490.

597. Hij overleed in de gevangenis op 23 januari 1980. De Court of Appeal is eerst nog nagegaan of het beroep wel namens Conlon kon plaatsvinden, aangezien hij ten tijde van het beroep nief meer leefde. Dit is bevestigend beantwoord. Zie R. v. Maguire and others, (1992) 2 All. E.R. 433, 435-436.

598. R. v. Maguire and others (1992) 2 All. E.R. 449-450; Editorial, Criminal Law Review, 1990, p. 613-614.

599. Op 21 november 1920 doodde de IRA (de Collins' squad) 14 Britse agenten. Later die dag werd door het protestante RIC (Royal Irish Constabulary - een semi militaire organisatie) en door de Black and Tans, die zo genoemd werden vanwege hun kleding en een slecht getrainde organisatie was die de RIC moest bijstaan. geschoten op publiek en spelers tijdens een voetbalwedstrijd in Dublin. Kelley, 1982, p. 41, 226-227. O'Beirne Ranelagh, 1983, p. 196. 
beroep te gaan. Dit verlof werd niet gegeven. ${ }^{600} \mathrm{Al}$ sinds juni 1979 werden er door o.a. familie, actiegroepen en kerkelijke instanties brieven gestuurd naar het Home Office met het verzoek naar de zaak van deze zes mannen te kijken. ${ }^{61}$ Op 28 oktober 1985 verscheen er een documentaire over de zes van Birmingham op de televisie. Vanaf die tijd vroegen parlementsleden herhaaldelijk aan de regering of de zaak van de zes vatbaar zou kunnen zijn voor herziening. Op 24 juli 1986 volgde er een debat in het parlement. Tijdens deze bespreking zei Mr. David Mellor, Under-Secretary of State, dat de minister pas zou beslissen over een verwijzing naar de Court of Appeal nadat hij, op grond van het boek van Chris Mullin van mening was dat er sprake was van nieuw bewijsmateriaal ${ }^{602}$ Op 20 januari 1987 volgde een verklaring van minister Hurd over een mogelijke verwijzing naar de Court of Appeal van verschillende IRA-zaken: Birmingham, Guildford en Woolwich, en Maguire ${ }^{603}$.

In het geval van de zes van Birmingham boden het boek van Chris Mullin en de uitzending van Granada Television voldoende grond voor het vermoeden van het bestaan van nieuw forensisch bewijs. Daarnaast was er een verklaring van een ex-politieagent die vertelde te hebben gezien dat de zes tijdens hun verblijf in het politiebureau mishandeld werden ${ }^{604}$ De zaak werd door de minister derhalve op grond van art. 17 van de Criminal Appeal Act 1968 verwezen naar de Court of Appeal. ${ }^{605}$ De Court of Appeal zag echter in januari 1988 geen reden toestemming te verlenen voor hoger beroep. ${ }^{606}$ Twee jaar later verwees de minister op 29 augustus 1990 de

600. R. V. Mcllkenny and others, (1992), 2 All E.R., 418.

601. 101 H.C.Deb., 6th Ser., written answers, kolom 57.

602. Mr. Mellor, 102, H.C. Deb., Gth Ser., kolom 814; Het boek waarnaar Mellor verwees is: Mullin, 1990 (eerste druk in 1986).

603. Bij de Guildford (en Woolwich) zaak waren vier mensen betrokken, te weten: Patrick Armstrong, Gerard Conlon, Paul Hill en Carole Richardson. De Maguire Seven, die op dat moment hun straf uitgezeten hadden, bestonden uit: Mrs. Maguire, haar man Patrick Maguire, hun zonen Vincent en Patrick, schoonbroer Patrick Conlon, Patrick O'Neill en Sean Smyth. De Maguire-zaak en de Guildford en Woolwich-zaak werden niet verwezen door de minister. 108 , H. C. Deb., 6th Ser., kolom 736.

604. Deze verklaring was afgelegd tijdens een onderzoek van de Devon and Corrwall Constabulary in 1987. Zie R. v. Mcllkenny, (1992) 2 All. E.R. 418.

605. Voor verwijzing naar de Court of Appeal door de minister gelden geen wettelijke criteria. Verwijzing kan ten allen tijde en onder alle omstandigheden geschieden. De minister houdt echter rekening met de eisen die door de Court of Appeal gesteld worden voor het toestan van hoger beroep. 108, H.C. Deb., 6th Ser., kolom 736-737.

606. R. W. Mcllkenny, (1992) 2 All. E.R. 418. 
zaak opnieuw naar de Court of Appeal, alweer op basis van nieuw bewijs. ${ }^{607}$ Deze keer, 25 februari 1991, besloot de Court of Appeal wel de zaak nog eens te bekijken. ${ }^{608}$ Het hof kwam tot de conclusie dat door het nieuwe forensische bewijgmateriaal de verklaringen van de deskundige $\mathrm{Dr}$. Skuse, waarin de forensische testen als betrouwbaar omschreven waren, in hoge mate in twijfel getrokken moesten worden en dat de verklaringen van enkele agenten betreffende de behandeling van de Birmingham $S i x$ onbetrouwbaar waren. Op de verklaringen wan Dr. Skuse en van de agenten waren de veroordelingen tot levenslang in 1975 voornamelijk gebaseerd. ${ }^{609}$ Het uiteindelijke resultaat was dat de uitspraken waarin de zes van Birmingham veroordeeld waren tot levenslange gevangenisstraffen, vernietigd werden. ${ }^{610}$ De zes van Birmingham kwamen na 16 jaar vrij.

\subsection{Judith Ward}

Judith Ward (25 jaar) werd in het najaar van 1974 verweten een bomaanslag. in het Euston station in Londen, een bomaanslag op een bus vol met soldaten en familieleden, waarbij twaalf doden vielen, en een bomaanslag bij het National Defence College in Buckinghamshire te hebben gepleegd. Het bewijs berustte voornamelijk op verklaringen van de verdachte en op forensisch materiaal: sporen van nitroglycerine op haar persoon en bezittingen. ${ }^{611}$ Op 4 november 1974 kreeg Ward, op de zitting alle feiten ontkennende, levenslang. $\mathrm{Zij}$ ging niet in hoger beroep. ${ }^{612}$

Op 17 september 1991 verwees de Home Secretary de zaak naar de Court of Appeal, omdat bezorgdheid was gerezen over de betrouwbaarheid van het forensisch bewijsmateriaal op basis van de vrijlatingen van de Zes van Birmingham en van het onderzoek van Sir John May in de Maguire-zaak. De barrister van Judith Ward voerde voor het hof nog een tweetal andere gronden aan. Ten eerste werd de vervolging verweten bepaald bewijsmateriaal ten tijde van de zitting in 1974 niet openbaar te hebben gemaakt en daarnaast was er bewijsmateriaal dat Judith Ward ten tijde van de verhoren psychisch niet stabiel genoeg was waardoor haar verklaringen niet betrouwbaar zouden zijn. ${ }^{63}$

607. 178, H.C. Deb. "6th Ser, wrinen answers, kolom 19.

608. 183, H.C. Deb. 6th Ser., kolom 608.

609. R. v. Mcllkenny and others (1992) 2 All. E.R. 417.

610. Op 14 maart 1991; 187. H.C. Deb. 6th Ser., kolom 1109.

611. Judith Theresa Ward, 96 Cr.App.R. (1993) C.A., p. 15-16.

612. Foot, 1993, p. 11

613. Judith Theresa Ward, 96 Cr.App.R. (1993) C.A., p. 18. 
Judith Ward bleek een persoon te zijn die tamelijk gauw bekende en op den duur ook geloofde bepaalde feiten te hebben gepleegd. ${ }^{614}$ Verklaringen van haar waarin zij aangaf onschuldig te zijn werden niet - in het openbaar belang - aan de verdediging of het hof openbaar gemaakt. Over het openbaar maken van gegevens die van belang kunnen zijn in een rechtszaak zei het hof al in de Maguire-zaak: 'The Court has now consistently taken the view that a failure to disclose what is known or possessed and which ought to have been disclosed is an "irregularity in the course of the trial". Why there was no disclosure is an irrelevant question, and if it be asked how the irregularity was "in the course of the trial" it can be answered that the duty of disclosure is a continuing one. ${ }^{1615}$ In de Judith Ward-zaak zei het hof: 'It is not difficult to imagine the arxieties which must have beset the police and the prosecution lawyers lest the lives of investigating officers, of members of the public, and even perhaps of Judith Ward herself might be put at risk by the disclosure of "sensitive" information. But the rule that the court and not the litigant must be the ultimate judge of where the balance of public interest lies must always have applied to the prosecution in criminal cases ..."6i6. 'In Miss Ward's case the disclosure of scientific evidence was woefully deficient. ${ }^{.617}$

Judith Ward, die op de zitting in 1974 had verklaard onschuldig te zijn, had de pech niet geloofd te worden vanwege het op dat moment overtuigende forensisch bewijsmateriaal: sporen van nitroglycerine. Uit psychiatrisch onderzoek van 1992 bleek dat Ward bepaalde niet door haar gepleegde feiten in 1974 bekende vanwege romantische denkbeelden die zij koesterde over haar leven en over haar land Ierland. ${ }^{618}$ Door deze bekentenissen wilde zij haar gevoel van eigenwaarde vergroten. 'Thus Miss Ward's claims to have associated with important personalities, serves to deceive not only others but Miss Ward herself. In this context I suspect that at times she has lost awareness of her own reality and fantasy has become a reality for her. ${ }^{, 619}$ Judith Ward bleek dus achteraf een gemakkelijk beïnvloedbare verdachte voor de politie te zijn geweest. De Engelsen zouden haar ' $\ldots a$ bit simple ...' genoemd hebben. Het is de vraag in hoeverre de politie er

614. Zie ook Mills in The Independent, 20 May 1993, p. 2; Interview met Michael Mansfield op 13 mei 1993.

615. Maguire and others (1992) 94 Cr. App.R., p. 146.

616. Judith Theresa Ward, (1993) 96, Cr.App.R., C.A., p. 27.

617. Judith Theresa Ward, (1993) 96, Cr.App.R., C.A., p. 51.

618. Zie de deskundigenverklaringen van dr. James MacKeith, dr. Bowden en dr. Gudjonsson. Judith Theresa Ward (1993) 96, Cr.App.R., P. 60-63.

619. Dr. Bowden in: Judith Theresa Ward, (1993) 96, Cr.App.R., C.A. p. 62. 
zelf van overtuigd was dat Ward de echte schuldige was. Voor enkele feiten had zij zelfs een waterdicht alibi. 620

\subsection{Miscarriages of justice}

Al lijken de vier zaken hierboven op elkaar, toch zijn er wel degelijk verschillen. De Guildford-zaak berustte alleen op verklaringen van de verdachten. De Maguire-famillie werd alleen veroordeeld op basis van forensisch bewijsmateriaal. Het bewijsmateriaal in de zaken van de Zes van Birmingham en Judith Ward tenslotte was een combinatie van forensisch bewijs en van verklaringen.

In a] deze zaken stond de politie onder grote druk van de publieke opinie om de zaken zo spoedig mogelijk rond te krijgen. In de opsporingsfase zijn dan ook de eerste fouten gemaakt. We kunnen hier niet geheel voorbijgaan aan de tol die de media hebben bij het ontstaan van miscarriages of justice. Zoais Sedley schrijf: "At its worst the press can be a source of prejudice that ... actually promotes miscarriages of justice. ${ }^{621}$ Verder is er de politie die door middel van geweld valse verklaringen afdwong. Ook wetenschappers die forensische testen moesten uitvoeren, hebben zich niet conform de regels gedragen. ${ }^{622}$ De wetenschappers hebben eerder hun gelijk willen bewijzen dan na te gaan in hoeverre de testen betrouwbaar waren. ${ }^{623}$ In alle zaken bleek eveneens dat de prosecution, de rechterlijke macht en de politiek aarzelden fouten van politie en deskundigen toe te geven. Hierna ga ik wat uitgebreider in op deze materie.

De bovenvermelde IRA-zaken hebben Groot-Brittannië veel negatieve publiciteit bezorgd: Het is ook geen kleinigheid als blijkt dat een aantal mensen meer dan tien jaar ten onrechte in de gevangenis zit. Naast deze gevallen zijn er nog talloze andere uitspraken die op het punt staan vernietigd te worden vanwege het feit dat de politie bewijsmateriaal vervalst of afgedwongen heeft. De Serious Crime Squad van de West Mialands - de streek

620. De politie hield bovendien informatie achter dat Ward enigszins labiel was. Interview op 14 mei 1993 met Alistair Logan, die zes jaar haar solicitor is geweest. Zie ook Foot, 1993, p. 11-12,

621. Sedley, 1993, p. 3; zie ook Bemnett, 1993, p. 3.

622. Zie bijvoorbeeld de strafzak tegen Judith Theresa Ward, (1993) 96, Cr. App.R., C.A. p. 45-53. In R. v. Maguire werd uitgemaakt dat de instantie die verwolgt verantwoordelijk is voor al degenen die haar advies geven. Dit omvat derhalve agenten als mensen die in opdracht van de prosecution forensisch onderzoek verrichten. Zie ook R. v. Maguire, The Journal of Criminal Law, November 1992 , p. 345 .

623. Sedley, 1993, p. 6. 
waar zich veel van deze zaken hebben voorgedaan - heeft jarenlang van deze technieken gebruik gemaakt. ${ }^{624}$ De politie heeft zich in de loop der jaren herhaaldelijk schuldig gemaakt aan het afdwingen van bekentenissen of het vervalsen van getuigenissen. ${ }^{625}$

Het meest schokkende van dit alles is dat in de Bimingham Six-zaak de politie al eind 1975 wist dat de zes de bomaanslagen niet gepleegd hadden en dat zij geen enkele poging ondernam om de zes op vrije voeten te stellen: ${ }^{626}$ Ook in de Guildford Four-zalak pakte de politie na korte tijd drie mensen op die verklaarden verantwoordelijk te zijn voor de bomaanslagen. Hill, Conlon, Armstrong en Richardson werden echter niet vrijgelaten omdat de bomaanslagen in Guildford en Woolwich door in totaal zeven of acht mensen gepleegd zouden zijn. ${ }^{627}$

\subsection{Remedie tegen miscarriages of justice}

Wanneer een veroordeelde van mening is dat hij onschuldig in de gevangenis zit, richt hij een verzoekschrift tot de minister van het Home Office, die de zaak vervolgens bekijkt. ${ }^{628}$ Op grond van de Crimimal Appeal Act 1968 kan de minister de zaak verwijzen naar de Court of Appeal, die de zaak in beroep zal afdoen ${ }^{629}$. Ook kan hij de Court of Appeal naar zijn mening vragen omtrent een bepaald punt in de $z^{2 a a k}{ }^{630}$. Een moeilijkheid die hier

624. De afdeling is inmiddels opgedoekt, omdat de corruptie routine was geworden. Tegen enkele agenten van de West-Midlands-politie zijn (disciplinaire) acties ondernomen, maar in geen enkel geval zijn er veroordelingen geweest. De Serious Crime Squad werd in 1989 ontbonden. Zie bijvoorbeeld 156, H.C. Deb., 6th Ser., written answers, kolommen 192-194, 425-427; 157 H.C. Deb., 6th Ser, written answers, kolom 706. Zie eveneens Lensing. 1991, p. 1051; Tregilgas-Davey, 1991, p. 668; Walker, 1993, p. 10-11.

625. Zie ook Niemantsverdriet, 1991, p. 17, 19. In dit artikel wordt ook nog melding gemaakt van de ontbinding van deze afdeling in 1989, wanwege het feit dat veel bekentenissen afgedwongen waren. Zie 158 , H.C. Deb., 6th Ser, kolommen 1036-1039, written answers, kolommen 605-606; 167, H.C. Deb., 6th Ser. kolom 1061; Mullin, 1990, p. 220 e.v. beschrijft hoe het verkrijgen van een bekentenis bij deze afdeling geschiedt.

626. De politie beschikte over een verklaring van een informant die lid was van de Birmingham IRA, waarin deze de naam noemde van degene die feitelijk één van de bommen geplaatst had. Mullin, 1990, p. 321-322; zie ook 171, H.C. Deb., 6th Ser, kolommen 1198-1199. Hilliard wijst op lacunes in de bewijswoering inzake de Birmingham Six-zaak. Hilliard, 1991, p. 393.

627. De Bruyne, 1991, p. 13; zie ook The Independent, 20 May 1993, p. 25.

628. Zander, 1988, p. 563.

629. Ant. 17 lid 1 onder a Criminal Appeal Act 1968.

630. Art. 17 lid 1 onder b Criminal Appeal ACt 1968. 
meespeelt, is dat de minister zal moeten proberen te voorkomen dat hij inbreuk makt op de onafhankelijkheid van de rechterlijke macht. Hurd verwoordde dat aldus op 20 januari 1987: “... a Home Secretary must never allow himself to forget that he is an elected politician and that, under out system, the process of justice must be kept separate from the political process.... it is not open to a Home Secretary simply to substitute his own view of a case for that of the courts. ... A different situation arises, of course, if new evidence or some new consideration of substance is produced which was not available at the trial or before the Court of Appeal." van het Home Office maakt maar zelden gebruik van de mogelijkheid van het verwijzen van zaken. Het verwijzen van zaken naar de Court of Appeal brengt niet met zich mee dat het hof automatisch toestemming zal geven voor hoger beroep. In de gevallen dat uitspraken vernietigd worden en er sprake is van een miscarriage of justice, wordt door de Home Secretary op grond van art. 133 Criminal Justice Act 1988 compensatie betaald voor het aangedane onrecht aan de persoon of, indien overleden, aan -ijn nabestaanden. ${ }^{632}$

\subsection{Problemen in de zaken}

\subsubsection{Rechterlijke macht}

Het strafproces moet het vertrouwen van de burgers hebben wil het geloofwaardig en geaccepteerd kunnen worden. Dit is het geval als vervolgingsinstanties en de rechterlijke macht volgens de wetten handelen. De commotie rond de verschillende 'IRA'-zaken laat zien dat de Britse maatschappij het vertrouwen in de strafrechtelijke procedure voor een deel $\mathrm{kwijt}$ is. Het werd immers bekend dat door de jaren heen veel fouten gemaakt en verzwegen zijn. ${ }^{633}$ Hadden de fouten werzwegen moeten worden? Zou het beter geweest zijn voor de geloofwaardigheid in het strafrechtsysteem als de zaken niet in de openbaarheid waren gebracht? Lord Denning zou hierop een bevestigend antwoord hebben gegeven: 'My opinion is that it is more important to uphold public confidence in our system of justice than to allow convicted people - whom the media on their own investigations allege to be innocent - go free. ${ }^{634}$

631. 108, H.C. Deb., 6th Ser., kolom 735.

632. Haisbury's Statutes of England, vol 12, Criminal Law, Criminal Appeal Act 1968 , art. 17, p. 403; 158, H.C. Deb., 6th Ser., kolom 279.

633. Zuckerman, 1991, p. 492; Malleson. 1991, p. 323.

634. Lord Denning geciteerd in Zander, 1988 , p. 573 ; zie ook Nienantsverdriet, 1991, p. 21 . Het nythe systeem, dat wil zeggen een systeen waarin men ervan uitgaat dat alles volgens een bepaald patroon (regels en normen) verloopt en 
Fen krasse stelling. Dezelfde rechter had ook liever gezien dat de verdachten van de bomaanslagen ter dood waren veroordeeld en opgehangen omdat dan de hele zaak vergeten zou zijn geweest. ${ }^{635}$ De politie heeft fouten gemaakt - ik kom daar dadelijk op terug -, maar de officieren van justitie en de rechters hebben voorkomen dat de fouten op tijd hersteld konden worden. De rechters keerden zich tegen het vernietigen van uitspraken want anders zouden ze moeten toegeven dat kopstukken binnen de rechterlijke macht verkeerde beslissingen hadden genomen. Het imago van de rechters werd daarmee immers aangetast. Eén rechter, Lord Bridge, die in eerste instantie rechter in de Birmingham Six-zaak was, is later rechter in de Count of Appeal geworden, en was dus zeker niet genegen om zijn eigen uitspraak te vernietigen. ${ }^{636}$ Het feit dat de rechters geselecteerd worden uit een klein gezelschap van barristers dat over het algemeen uit de hoogste sociale klasse komt, vormt een hindernis voor het contradictoire Engelse strafproces. In dit proces waar verdachte en vervolgende instantie tegenover elkaar staan, is er geen plaats voor de veronderstelling dat de politie kan liegen of mishandelen. Dat idee komt niet bij de rechters op. Lord Denning beaamde dat na de vrijlating van de Birmingham $\operatorname{Six}{ }^{637}$

\subsubsection{De beroepsprocedure}

Op de Britse eilanden geldt voor indictable offences (te vergelijken met de Nederlandse misdrijven) een beperkte mogelijkheid tot hoger beroep. $\mathrm{Na}$ een uitspraak van de Crown Court (met een jury-rechtspraak) is er hoger beroep mogelijk bij de strafkamer van de Court of Appeal. Daarvoor moet dan wel eerst toestemming verkregen worden, tenzij het een rechtsvraag betreft. ${ }^{638}$ De Court of Appeal kijkt niet opnieuw naar de zaak, maar behandelt alleen wat door partijen is aangevoerd. De Court of Appeal heeft de mogelijkheid de zaak terug te wijzen naar de Crown Count waar cen nieuwe

634. $\rightarrow$

afwijkingen niet voorkomen, staat mogelijke veranderingen derhalve in de weg. Zie verder.

635. Niemantsverdriet, 1991, p. 17-19; Hillyard, 1994, p. 74-75; The Times, 17 augustus 1990 , p. 4, "Denning suggests chatty asides were used out of context".

636. Niemantsverdriet, 1991 , p. 21.

637. Sterker nog: na de uitspraak (vrijlating) in de zaak tegen de drie agenten die een verklaring yan één van de Guildford Four vervalst zouden hebben, zei Lord Denning: 'I think it was very wrong that the police officers were ever accused. I have always had complete confidence in the police testimony in de Guildford case." The Times, 20 May 1993, p. 1; De Bruyne, 1991, p. 13; Niemantsverdriet, 1991 , p. 21.

638. Malleson, 1991 , p. 324. 
jury zich kan buigen over de gehele zaak. ${ }^{639}$ Maar het hof maakt maar zeer zelden van deze mogelijkheid gebruik. ${ }^{60}$ Hoger beroep is slechts één keer mogelijk. Indien er nieuw bewijsmateriaal is en de verdachte al eens in hoger beroep is gegaan, dan moet hij een verzoek aan de Home Secretary richten om de zaak te verwijzen naar de Court of Appeal. ${ }^{641}$ Dit geschiedt op basis van art. 17 Criminal Appeal Act 1968. Als men in gedachten houdt dat er gemiddeld vijf zaken per jaar door de minister verwezen worden, kunnen we stellen dat deze beroepsprocedure niet veel voorstelt. ${ }^{642}$ Deze manier van procesvoering in Engeland en Wales vormt voornamelijk een belemmering in die gevallen dat er sprake is van een miscarriage of justice. De mogelijkheden voor de verdachte om de zaak geheel opnieuw beoordeeld te zien zijn dan practisch nihil. ${ }^{643}$

\subsubsection{Een gematigd inquisitoir strafproces ?t4 $^{64}$}

Zoals bekend heeft Groot-Brittannië een contradictoir strafproces. Partijen staan op de zitting tegenover elkaar en proberen ieder de jury voor zich te winnen. Ten tijde van de veroordelingen in de verschillende IRA-zaken was de politie verantwoordelijk zowel voor de opsporing als voor de vervolging. Het probleem dat kon ontstaan was dat de agenten zich te veel zouden vereenzelvigen met hun zaak en dat het voor hen belangrijker was de zaak te winnen dan de waarheid te achterhalen. Het contradictoire proces zou tot corruptie kunnen leiden en agenten stimuleren bekentenissen af te dwingen. ${ }^{645}$ Met de komst van de Crown Prosecution Service kan dit probleem

639. Zie art. 7 Criminal Appeal Act 1968.

640. O'Connor, 1990 , p. 622-623 noemt wat cijfers. Tussen 1981 en 1986 zijn er 14 zaken verwezen naar de Crown Court. Zie ook Hans Niemantswerdriet, 1991. p. 21; o.a. de organisatie JUSTICE pleit ervoor dat de Court of Appeal vaker een retrial beveelt. Zander, 1988 , p. 556-557.

641. Tregilgas-Davey, 1991, p. 668-669.

642. Hoe machtiger het 'mythe'-systeem is hoe moeilijker het wordt om fouten toe te geven wanneer men geconfronteerd wordt met de 'operationele code'. Het systeem verdedigt zichzelf door fouten toe te schrijven aan menselijke fouten of aan de 'rotte appels'. Zie witvoeriger hoofdstuk 10.

643. Het is misschien interessant om hier te vermelden dat de Court of Appeal in 1907 na de Adolf Back-zaak juist in het leven is geroepen om miscarriages of justice te woorkomen. Veel lijkt het dus niet geholpen te hebben. Dit is trowwens ook een 'scandal en reform' voorbeeld. Zie Malleson, 1991, p. 331.

644. Het vooronderzoek kan gematigd inquisitoir gezien worden en het onderzoek ter terechtzinting als gematigd accusatoir. Over het algemeen noemt men ons systeem gematigd inquisitoir.

645. Deze corruptie zou geen persoonlijk belang ten doel hebben, maar eerder tot 
gedeeltelijk opgelost zijn. ${ }^{646}$ Desalniettemin vraagt Tregilgas-Davey zich af of het continentale systeem niet een beter alternatief voor het Engelse systeem zou kunnen zijn. In dit continentale systeem wordt het proces niet beheerst door een conflict tussen partijen, maar wordt getracht de waarheid analytisch te achterhalen. ${ }^{6 / 7}$ Daamaast verschilt de aard van het hoger beroep in landen op het continent

De Royal Commission on Criminal Justice, waarover hieronder zo direct meer, heeft in haar rapport ook aandacht besteed aan de verhouding inquisitoir-accusatoir. Daartoe heeft de commissie informatie verzameld over strafrechtssystemen in andere landen. Uiteindelijk is de commissie tot de conclusie gekomen dat een overgang naar een meer inquisitoir systeem, waarin de functies van opsporing en vervolging gefuseerd zijn en de rol van de rechter actief is, niet noodzakelijk betekent dat de belangen van de rechtspraak beter gediend zijn dan in een systeem waar de rollen van politie, vervolging en rechterlijke macht gescheiden zijn en de rol van de rechter bovendien "the arbiter of law (is) but not of fact."

\subsubsection{Politie}

Ik ben hierboven nogal uitvoerig op de verschillende casus en de problematiek van miscarriages of justice ingegaan. De rol die de politie in dit alles gespeeld heeft is m.i. heel belangrijk. Waar het mij om gaat is het feit dat politie-agenten crimineel gedrag kunnen vertonen zonder dat dit door hun bazen opgemerkt wordt of, in sommige gevallen zelfs door hun bazen geduld wordt. ${ }^{650}$ Al kan er veel kritiek geleverd worden op het Engelse strafproces, op de jury-rechtspraak en op de rol van de rechters gezien het feit

645. $\rightarrow$

doel on een zaak rond te krijgen in het belang van de organisatie en systeem. Tregilgas-Davey, 1991, p. 716-717; zie ook Niemantswerdriet, 1991, p. 19.

646. De CPS is ook tegen een meer inquisitoir strafproces. Dit in tegenstelling tot de politie, die in haar advies aan de Royal Commission on Criminal Justice wel opteerde voor een inquisitoire procesvorm. '... there need to be corresponding changes in the system of trial to move it away from an adversarial style to one that seeks the truth.' Citaat in Sprack, 1992, p. 67.

647. Tregilgas-Davey, 1991, p. 716.

648. Royal Commission on Criminal Justice, 1993 , p. 3.

649. Royal Commission on Criminal Justice, 1993, p. 4.

650. Net als in de Guildford-zaak hebben enkele agenten op het eind van 1993 zich voor hun gedrag in de Birningham Six-zaak moeten verantwoorden. Zij werden ervan verdacht bepaalde aantekeningen 'aangepast' te hebben. Interview met Michael Mansfield op 13 mei 1993. In de Guildford-zaak zijn de agenten in mei 1993, zoals bekend, vrijgesproken van bet telastegelegde. Zie The Independent van 20 May 1993. 
dat gemaakte fouten in stand kunnen blijven, toch ligt de bron van alle fouten meestal tijdens het onderzoek bij de politie. ${ }^{651}$ De problemen ontstaan in het algemeen in het vooronderzoek. Daar kunnen al dan niet met opzet fouten gemaakt worden. De onderzoeker Rattner waarschuwt voor het gevaar van een te ijverige politie. Door de wijze van vragen stellen aan verdachien en getuigen kan de politie tot verkeerde of voorbarige conclusies komen. Ook getuigenbewijs is niet geheel betrouwbaar. Getuigen kunnen oprecht denken iets gezien of iemand herkend te hebben maar het toch bij het verkeerde eind hebben. Fouten die gemaakt worden hoeven derhalve niet altijd aan de politie toegerekend te worden. ${ }^{652}$ Maar de politie zou oog moeten hebben voor de (on-) betrouwbaarheid van getuigenbewijs en dit bewijs kritisch moeten benaderen. ${ }^{653}$

Het feit dat de politie in staat was om bekentenissen af te dwingen, bewijsmateriaal te vervalsen en dossiers achter te houden, zonder dat prosecutors en rechters hier weet van kregen, - gevallen waarvan hier sprake is - roept wel de vraag op wie en waar de beschermers van orde en recht zijn. ${ }^{654}$ Waarom vertoont de politie dergelijk gedrag? En, zou hetzelfde gebeurd zijn indien de politie onderworpen was geweest aan andere vormen van interne of externe controle? Met de eerste vraag komen we voor een deel op het terrein van de psychologie. In het boek van Crombag, Van Koppen en Wagenaar wordt op deze vraag ingegaan. De schrijwers stellen dat de politie in sommige gevallen overtuigd is van de schuld van de verdachte(n), terwijl het bewijs in die zaak moeilijk rond te krijgen is. De politie besluit dan het bewijsmateriaal een handje te helpen of gemaakte fouten te verdoezelen. ${ }^{6.55}$ Aangezien de rechters over het algemeen ervan uitgaan dat agenten een op waarheid gebaseerd proces-verbaal opmaken, kunnen rechterlijke dwalingen op een dergelijke manier eenvoudig ontstaan.

Effectieve controle over de politie, d.w.z. het feitelijk op de vingers kijken van de politie door hun superieuren zou een oplossing kunnen zijn. ${ }^{656}$ Dit zou bijwoorbeeld kunnen door dat de lagere politierangen vaker verantwoording afleggen aan hun bazen, waarbij eveneens hun werk gecontroleerd wordt. Maar of dat een werkelijke oplossing is, blijft de wraag. Meer controle van buitenaf zou wellicht ook een remedie kunnen zijn. Daarbij denk ik niet aan het parlement omdat dit weer te ver afstaat van de politie. Eerder

651. Zie Rattner, 1988 , p. $283-293$.

652. Zuckerman, 1992, p. 336-337.

653. Zie ook Crombag, Van Koppen en Wagenaar, 1992, p. 123-153.

654. Zie bijvoorbeeld Forder/Steyger, 1991, p. 1053.

655. Crombag, Van Koppen en Wagenaar, 1992 " p. 149-152, 262-266; zie ook Barker en Carter, 1990, p. 61-73.

656. Zie Crombag. Van Koppen en Wagenaar, 1992, p. 266. 
heb ik een onafhankelijke instantie in gedachten, die het werk van de politie kan controleren. Nu zou men kumnen zeggen dat dat idee in Engeland is werwezenlijkt met de komst van de Crown Prosecution Service. Dat blijkt in de praktijk echter niet het geval te zijn. De CPS is een tamelijk zwakke organisatie die voor haar zaken geheel afhankelijk is van de politie. Aangezien de politie nog altijd zelfstandig onderzoek verricht, kan de CPS moeilijk nagaan waar de politie niet correct opgetreden is. Het ontbreekt de CPS aan de nodige middelen. De prosecutor kan slechts nagaan of vervolging voor de rechtbank haalbaar en reëel is. Met dit doel is de dienst immers in het leven geroepen. Het gehele Engelse strafrechtsysteem is gebaseend op zaken voorgelegd door de prosecutor, maar volledig voorbereid en onderzocht door agenten. Agenten sporen strafbare feiten op, zij zoeken bewijsmateriaall en leggen een kant en klaar dossier voor aan de prosecutor die vanzelfsprekend uitgaat van de juistheid van de verkregen informatie. ${ }^{65}$ Op deze wijze kunnen al dan niet opzettelijk gemaakte fouten bijna niet achterhaald worden. ${ }^{658}$ Nijboer is van mening dat het weinig zin heeft om door de politie begane fouten aan het systeem toe te schrijven. ${ }^{659}$ Het gaat volgens hem met name om het menselijk gedrag en om de werkdruk waarmee de justitiële instanties te maken hebben. Het is de vraag of in deze visie, waar de gemaakte fouten aan persoonlijke factoren toegeschreven worden, niet het falen van de controle over de politie ontkend wordt en het probleem verder als niet bestaand afgedaan wordt.

Zou een oplossing te vinden zijn in de wijze waarop op het continent het voorbereidend onderzoek geschiedt, d.w.z. met een officier van justitie die betrokken wordt bij het vooronderzoek en die van het begin af an de leiding daarover heeft? Maar zelfs binnen het continentale systeem is toezicht op de politie niet constant aanwezig. Ook daar is de officier van justitic niet altijd aanwezig bij de politieverhoren, en verschijnt hij maar zelden op het politiebureau. ${ }^{60}$ Wat gebeurt op straat en bij het staandle houden en aanhouden van verdachten valt nooit geheel te controleren, tenzij al het handelen op videoband opgenomen zou worden. Veel pollitie-optreden geschiedt (nu nog) in het duister ${ }^{6.61}$

657. In Nederland gaat men er eveneens wanuit dat hetgeen een agent verklaart juist is. Zie art $344 \mathrm{~Sv}$.

658. Zie over dit alles Zuckerman, 1992 , p. 323-326.

659. Nijboer, 1992, p. 11.

660. Het onderzoek van Crombag, Van Koppen en Wagenaar laat zien dat ook in Nederland de Officier van Justitie tekort kan schieten in de controlerendie taak, al dan niet opzettelijk. 1992, p. 266.

661. Voor de Nederlandse situatie stellen Crombag, Van Koppen en Wagenaar voor om veroordelingen op grond van alleen processen-verbaal van de politie niet meer mogelijk te maken. 1992, p. 268. 


\subsection{Het parlement}

"Will the Home Secretary tell the House what the hell is going on in the British judictal system? We have had Wholmich. Guildford, the case we cannot refer today because it is sub judice (Maguire Seven. CR), and we shall have the Birmingham Six before long. Many people in this country are beginning to believe that a combination of perjured police officers, judges who are clearly biased and compliant Ministers is reducing the British judicial system to low farce. In view of the times that the Home Serretary has had to eat his own words, would not it be better if he printed them on rice paper to make his task more palatable?"6r2

Is it right that we should try so hard to discredit our own system of justice? ?.653

Hierboven is er al melding van gemaakt dat minister Hurd op 20 januari 1987 heeft geweigerd de Guildford en Woolwich en de Maguire-zaken te verwijzen, maar dat wel deed in de Birmingham-zaak. Tijdens het debat dat. op deze beslissing volgde, was er van enkele kanten onvrede te horen over het feit dat niet alle zaken verwezen werden naar de Court of Appeal. Eén parlementslid bracht een zaak in herinnering die door de Home Secretary Whitelaw tot vier maal toe verwezen was naar de Court of Appeal, maar door dit hof steeds afgewezen was. Uiteindelijk had de toenmalige minister zelf maar de mensen in die zaak het pardon gegeven. ${ }^{664}$ Andere leden vroegen de minister om het hof te verzoeken de zaak voor te leggen aan een nieuwe jury. Dit alles illustreerde dat het vertrouwen van het Lagerhuis in de Court of Appeal aan het verminderen was. De minister bleef ondertussen brieven en handtekeningen ontwangen van mensen met het verzoek de veroordelingen te herzien. ${ }^{65}$ De Court of Appeal wees in 1988 het hoger beroep in de Birmingham-zaak af. ${ }^{666}$

662. Mr. Tony Banks, 176, H.C. Deb., 6th Ser, kolom 446.

663. Mr. Stanbrook over de Birmingham Six bombings, 180, H.C. Deb., 6th Ser. kolom 324.

664. De minister heeft de mogelijkheid dit te doen, maar is zuinig met die bevoegdheid. Eerst wordt altijd afgewacht wellke beslissingen de rechterlijke macht zal geven. Clare Short, 108, H.C. Deb., 6th Ser., kollom 741.

665. Zie bijwoorbeeld 116, H.C. Deb., 6th Ser., mritten answers, kolom 469. Deze hele kwestie heeft er trouwens ook toe geleid dat onderhandelingen met de Republiek lerland over het uitleveren van personen mislukt zijn. Zie 119, H.C. Deb., Gth Ser, kolom 1262.

666. In deze uitspraak verklaarde de Count of Appeal: "Whe have no doubt that these convictions were both safe and satisfactory." 137, H.C. Deb., 6th Ser, kolom 14; 126. H.C. Deb., 6th Ser., written answers, kolom 705-706. 
De minister besloot na de vrijlating van de Guldford Four een onderzoek in te stellen onder leiding van Sir John May. Toen in 1990 nieuw bewijsmateriaal beschikbaar kwam over de Zes van Birmingham, werden weer tal van vragen afgevuurd op de minister ${ }^{667}$ Veel van deze vragen betroffen het gedrag van agenten die ten tijde van de bomaanslagen werkzaam waren bij de West Midlands Police. ${ }^{668}$ Daarnaast werden er vragen gesteld of het niet wenselijk zou zijn een geheel onafhankelijk Supreme Court of Appeal in het leven te roepen. ${ }^{659}$

\subsection{De situatie na PACE 1984}

\subsubsection{Inleiding}

De gebeurtenissen die ik in dit hoofdstuk ${ }^{670}$ schetste, hebben allemaal plaatsgevonden voor 1984. Op 1 januari 1986 werden de Police and Criminal Evidence Act 1984 (PACE 1984) en de bijbehorende Codes of Practi$c e^{671}$ van kracht. De wet gaat uitvoerig in op de bevoegdheden van de politie. De Codes of Practice behandelen veel facetten van het wooronderzoek. De Code of Practice for the Detention, Treatment and Questioning of Persons by Police Officers, behorende bij de PACE 1984, geeft aan hoe de politie moet optreden tegen verdachten.

Heeft de PACE 1984 nu al veel verbeteringen aangebracht? Is het ook tegenwoordig nog mogelijk dat zoiets als een miscarriage of justice of een grote rel kan vóorkomen? De commissie zou moeten onderzoeken in hoeverre de PACE 1984 voor een deel de geconstateerde problemen heeft opgelost of kan voorkomen. In 1987 en 1988 is door de universiteit van Hull hierover onderzoek verricht. ${ }^{672}$ Volgens de onderzoekers is de in-

667. 165, H.C. Deb., 6h Ser., kolom 1034-1037, written answers, kolommen 862 , 864; 167, H.C. Deb., 6th Ser., kolom 1058.

668. Zie bijwoarbeeld 167, H.C. Deb., 6th Ser., kolom 1061; 174, H.C. Deb., 6th Ser, kolom 263.

669. 176, H.C. Deb., 6h Ser., kolom 16.

670. 9.3 tot en met 9.6 .

671. Deze richtijinen geven aan hoe de politie in bepaalde situaties zou behoren te reagenen. Er zijn vier Codes of Practice: 1) for the Detention, Treatment and Questioning of Persons by Police Officers, 2) for the Identification of Persons by Police Officers, 3) for the Searching of Premises by Police Officers and the Seizure of Property found by Police Officers an Persons or Premises, 4) for the Exercise by Police Officers of Statutory Powers of Stop and Search.

672. Bottomley, K, C. Coleman, D. Dixon, M. Gill en D. Wall, The Impact of PACE: Policing in a Worthern Force, 1991, Centre for Criminology and Criminal Justice, University of Hull. 
vloed van de PACE 1984 positief op het optreden van de pollitie in het politiebureau, maar niet daarbuiten. ${ }^{673}$ De PACE 1984 heeft onder meer tot gevolg gehad dat verhoren op band worden opgenomen. Dit verkort de detentie- en verhoortijd van verdachten aanzienlijk. Ook de agenten zijn over het algemeen tewreden met het opnemen van verhoren, omdat dat misverstanden over de ware inhoud van een verhoor uitsluit. Desalniettemin voorkomt een opgenomen verhoor niet altijd onjuist optreden van de politie. Het onderzoek van de universiteit van Hull liet zien dat in sommige gevallen bekentenissen van te voren waren afgedwongen of dat soms de bandopname tijdens een verhoor stopgezet werd. ${ }^{674}$ Ander onderzoek van Sanders en Bridges laat zien dat na de PACE 1984 meer verdachten juridische hulp van advocaten kregen maar dat de verdachtem vaak niet op de hoogte waren van het feit dat die hulp gratis kon zijn. ${ }^{675}$ Dat 'verzuimden' agenten te vermelden.

Helaas laat de huidige situatie in Engeland en Wales dus zien dat nog veel voor verbetering vatbaar is op de Britse eilanden. Zo is er de zaak van de Cardiff Three over de moord op een prostituee, waarin bekentenissen werden afgedwongen. ${ }^{676}$ Verder zijn er de $R$. $v$. Canal $e^{677}$-zakak over het schenden van één van de Codes of Practice, de Tottenham Three-Broadwater Farm-zaak ${ }^{678}$, Stefan Kiszko, de Darvall Brothers, de Taylor Sisters en Ivan Fergus. ${ }^{679}$ Uit de Cardiff Three-zaak bleek dat de politie zelfs in aanwezigheid van een bandrecorder niet schroomt om bepaald onjuist gedrag te vertonen. In deze specifieke zaak oordeelde de Court of Appeal eind 1992, na het beluisteren van een bandopname van een politieverhoor, dat de drie verdachten vrijuit moesten gaan. ${ }^{680}$ Rechterlijke controle is hier

673. Coleman, Dixon en Bottomley, 1993, p. 31; In dit onderzoek gaf de meerderheid van de agenten aan dat haar stop and search-optreden na de irwoering van PACE 1984 niet veranderd was. 1993, p. 21.

674. Mensen passen zich aan nieuwe regels en zoeken creatieve oplossingen bijvoorbeeld bekentenissen worden nu in de auto of buiten op straat gedaan. Coleman, Dixon en Bottomley, 1993, p. 29.

675. Section 58 lid 1 PACE 1984: "A person arrested and held in custody ... shall be entitled, if he so requires, to consult a solicitor privately at any time." De Code of Practice verplicht de agenten de verdachten te informeren over hun rechten. Zie ook Sanders en Bridges, 1993, p. 38-39.

676. Royal Commission on Criminal Justice, 1993, p. 6.

677. (1990) 2 All E.R., CA, p. 187-192.

678. Ook well de Silcott-zaak genoend. Zie o. a. Mansfield, Wardle, 1993, p. 93.
679. Bridges en McConville, 1994, p. 3-4.

680. Interview met Michael Mansfield, die in deze zaak barrister was, op 13 mei 1993. Zie ook Royal Commission on Criminal Justice, 1993, p. 12. 
effectief geweest maar het is de vraag in hoeverre het mogelijk is om in alle zaken bandopnamen van verhoren te beluisteren. ${ }^{681}$

\subsubsection{De Miller-zaak}

Stephen Miller, éen van de Cardiff Three, werd verdacht van het vermoorden van een prostituee. Het enige bewijs tegen hem was een leugenachtige verklaring van een collega-prostituee die verklaarde hem op de plek van de moord gezien te hebben. Op grond van deze getuigenis zetten politieagenten Miller onder grote druk om een bekentemis af te leggen. Deze Miller was geestelijk minder begaafd. Tijdens de vele verhoren was in de meeste gevallen zijn raadsman aanwezig. De verhoren werden op band opgenomen. "Until then (December 1992) everyone had imagined that the presence of a lawyer and a tape-recorder would provide the necessary protection against unreliable confessions and therefore could form part of the preconditions for admissibility of any confession. ${ }^{682}$ Ondanks de herhalde ontkenningen van Miller praatten agenten hem een bekentenis aan. De Court of Appeal die in beroep op de zalk besliste kwam na het beluisteren van de banden to de concilusie dat Miller vrijgesproken moest worden. Het gedrag van de agenten tijdens de verhoren viel niet goed te praten. Het opmerkelijke in deze zaak was dat de agenten zelfs in aanwezigheid wan een raadsman ${ }^{683}$ niet schroomden agressie te gebruiken en te veel druk uit te oefenen tijdems de verhoren. ${ }^{684}$

\subsubsection{Police Constable Tony Salt}

De zaak 'police constable Tony Salt' betreft de onverwachte dood van agent Tony Salt op 17 april 1989 tijdens het uitoefenen van zijn dienst. Samen met zijn collega PC Mark Berry had hij de taak in plain clothes een illegale nachtclub in de gaten te houden vanuit een nabijgelegen pand. Tegen middernacht hadden de agenten twee keer hun post verlaten om in een café een pilsje te drinken. $P C$ Salt ging de tweede keer niet meer naar zijn post terug maar verdween in de richting van de nachtclub. $P C$ Berry daarentegen ging wel weer terug en zag vanuit het raam Salt even later plotseling vallen. Korte tijd later overleed $P C$. Sallt. Zijn collega legde na zijn overlijden tenminste vier verschillende verklaringen af. In enkele daarvan komen twee of drie West-Indiërs naar voren die PC Salt beroofd zouden hebben. Als gevolg van deze verklaring werden drie personen gearresteerd die naar later

681. Dat zou in ieder geval indirect ten goede komen aan het onmiddellijkheidsbeginsel.

682. Mansfield, Wardle, 1993, p. 93.

683. Solicitor.

684. Interview met Michael Mansfield, op 13 mei 1993. 
bleek onder dwang een bekentenis aflegden. Hun bekentenissen waren op video opgenomen en van te voren uitwoerig "geoefend" 685 Hun werd uiteindelijk moord ten laste gelegd. Struikelblok voor hun veroordeling waren getuigen die verklaarden dat de verdachten die awond al veel vroeger dan het gebeurde nalar huis waren gegaan. Toen uiteindelijk de weduwe van $P C$ Salt verklaarde dat haar echtgenoot helemaal niet beroofd kon zijn omdat de vermeende geroofde dingen gewoon thuis waren, bleek dat er het een en ander mis was gegaan. Toch heeft de politie deze informatie in eerste instantie achtergehouden woor de verdediging. ${ }^{60}$ Omdat in het dossier de paginanummers niet gewoon doorliepen (een domme fout van de agenten), kwamen de achtergehouden pagina's - waaronder de verklaring van de echtgenote wan $P C$ Salt - boven water. ${ }^{687}$

\subsubsection{De PACE 1984}

De PACE 1984 wormt gezien de PC Tony Salt-zaak nog steeds geen echte bescherming. De bedoeling van deze wet was immers enerzijds de rechten van de verdachten die in voorarrest zitten, vast te leggen en anderzijds de bevoegdheden van de politie nader te omschrijven. Een equally and fair balance tussen prosecution en verdediging zou de basis van het strafrechtsysteem moeten zijn. ${ }^{689}$ De politie gaat nog te veel uit van de presumption of guilt en probeert derhalve de verdachten te laten bekennen. Wat de PACE 1984 ook niet heeft kunnen voorkomen, zijn de verklaringen van agenten die beweren, weliswaar ook valak terecht, dat een verdachte buiten de aarwezigheid van bandapparatuur tegen de agent verklaart: 'All right, Guv, $I$ did it." Deze verklaring kan dan toch meewerken woor het bewijs. Echter het is moeilijk woor de verdachte om aan te tonen dat hij dat niet gezegd heeft. De politie legt nog veel te veel nadruk op bekentenissen. $\mathrm{Zij}$

685. Ook deze zaak bracht parlementslid Chris Mullin in het House of Commons nax woren. 200, H.C. Deb., Gth Ser., kolommen 1222-1224.

686. Dat was al volgens de rechtspraak onjuist. In R. v. Hennessey (1979) 68 Cr.App. Rep. 419, zei de Cowrt of Appeas" (p. 426): '... those who prepare and conduct prosecutions owe a duty to the courts to ensure that all relevant evidence of help to an accused is either led by them or made avallable to the defence. He have no reason to think that this dury is neglected; and if it ever should be, the appropriate disciplinary bodies can be expected to rake action. The judges for their part will ensure that the Crown gets no advantage from neglect of duty on the part of the prosecution."

687. 200, H.C. Deb., 6th Ser., kolom 1224

688. Zie bijvoorbeeld Bevan en Lidstone, 1985, p. 1-2; Zander, 1988. p. 129.

689. Vaak in de auto op weg naar het politiebureau. Interview met Michael Mansfield op 13 mei 1993. 
zien bekentenissen als het beste bewijsmateriaal. Met bekentenissen kunnen de zaken ook snel afgerond worden. ${ }^{600}$

In een voorgaand hoofdstuk is de PACE 1984 al aan de orde gekomen. Daarbij is al gesteld dat de PACE 1984 al bij de inwoering van vele kanten werd bekritiseerd. De commissie heeft de kans gehad de werking van deze wet aan een onderzoek te onderwerpen. Hetzelfde kan gezegd worden van de Prosecution of Offences Act 1985, die in 1986 in werking is getreden. ${ }^{691}$

De PACE 1984 heeft er niet echt voor kunnen zorgen dat miscarriages of justice niet meer zullen vóórkomen. Het bestaan van een wet op zich geeft geen voldoende waarborgen dat de wet niet overtreden zal worden. Wetten die de strafrechtsprocedure regelen kunnen er wel voor zorgen dat bepaalde trucs van agenten eerder ontdekt worden. De Miller-zaak is hiervan een voorbeeld.

\subsection{Een Royal Commission?}

Na de vernietiging van de aitspraken in de zaken van de Vier van Guildford, de Zes van Birmingham en de Zeven van de familie Maguire ${ }^{692}$, werd besloten op grond van al deze zaken een commissie te benoemen, ${ }^{693}$ de Royal Commission on Criminal Justice. Zij had tot taak gekregen na te gaan in hoeverre het strafrechtsysteem veranderd moest worden. ${ }^{64}$ De opdracht die de commissie meekreeg is heel ruim en omvat verscheidene aspecten van het vooronderzoek, het onderzoek ter terechtzitting en de beroepsmogelijkheden. ${ }^{655}$ Het is niet zo dat de opdracht die de commissie gekregen heeft zich beperkte tot het voorkómen van miscarriages of justice. De commissie zou ook moeten kijken naar de right of silence, met name in

690. Interview met Michael Mansfield op 13 mei 1993. Zie ook Mr. Paul Condon en Mr. John Greenway in: Home Affairs Committee, Policing, Minutes of Evidence, 24 March 1993, p. 26-27.

691. Zie ook Lensing, 1991, p. 1052.

692. Hillyard, 1994, p. 70.

693. Dit gebeurde op 14 maart 1991. 187, H.C. Deb. 6th Ser., kolom $1109-1110$.

694. Al is het goed dat een commissie het gehele strafrechtsysteem onder de loep neemi, het nadeel van cen commissie is wel dat de zaak daardoor eindeloos vertraagd wordt. Zie ook Mr. Roy Hattersley " 187, H.C. Deb., 6th ser., kolom 1111-1112.

695. The Royal Commission on Criminal Justice, Press release: Royal Commission on Criminal Justice imvites written evidence, 14 juni 1991; zie ook Editorial. Criminal Law Review, 1991, p. 489. 
hoeverre dit recht tot $z$ wijgen moest blijven bestaan. ${ }^{6 \%}$ De commissie moest dus zowel bestuderen hoe de verdachte beter beschermd kon worden als nagaan of bepaalde rechten wan verdachten nog wel nodig waren. ${ }^{697}$

In concreto moest de commissie de effectiviteit van het strafrechtsysteem betreffendle het beschermen van onschuldigen en het veroordelen van schuldigen nagaan en met name moest de commissie bekijken of veranderingen wenselijk waren op het gebied van:

1. politieonderzoek en de controle daarop;

2. de rol van de prosecutor bij de controle op de bewijsvergaring;

3. de rol van deskundigen in de gehele procedure en de verhouding politie-deskundigen;

4. de regelingen betreffende legal advice en het recht op een advocaat;

5. de mogelijkheden van de verdachte om zich te verdedigen en de mate waarin de rechtbank conclusies mag trekken uit actief of passief gedrag van de verdachte;

6. de bevoegdheden van de rechters gedurende de gehele procedure en de bewijsregeling;

7. de rol van de Court of Appeal inzake beroepszaken;

8. de regelingen voor het onderzoeken van zogenaamde miscarriages of justice als verdere beroepsmogelijkheden uitgeput zijn.

De commissie stond onder voorzitterschap van Viscount Runciman, en bestond verder uit Sir Robert Bunyard, Sir John Cadogan, Professor John Gunn, Sir John May, Yve Newbold, Usha Prashar, Anne Rafferty, Sir John Wickerson, Sir Philip Woodfield en Professor Michael Zander. ${ }^{698}$ De

696. Woral de politie dringt aan op het af $z$ wakken van deze regel. Mr. Greenway onderwond jaren geleden al dat :"... In those days we were frustrated, I thought, by the judges" mules; by the right to silence. Since then it has got worse because. you now have the Police and Evidence Act." Nu is het juist ironisch dat de agenten die in mei 1993 voor de Old Bailey in Londen terechtstonden woor het vervalsen van een verklaring van eén van de vier wan Guildford, allemaal gebruik van dit recht gemaakt hebben. Interview met Chris Mullin, MP Labour, op 13 mei 1993. Mr. Greenway, Policing, Minutes of Evidence: Mr. Paul Condon, QPM, Home Affairs Committee, Wednesday 24 March 1993, London, HMSO, p. 27.

697. Een voorbeeld van verrechtsing van het politieke denken in Engeland en Walles ten tijde van de regering van Thatcher, hetgeen gekenmerkt wordt door een dilemma. Aan de ene kant miscarriages en het toekennen vari rechten aan verdachten en aan de andere kant de handhaving van law and order en het verminderen wan rechten.

698. Viscount Runciman, Voorzitter van de Andrew Weir and Co. Ltd. en Senior 
commissie kreeg twee jaar de tijd. om haar rapport uit te brengen. Gezien de opdracht die de commissie kreeg, is een termijn van twee jaar niet te lang. Maar volgens de redactie van de New Law Journal, een juridisch tijdschrift in Groot-Brittannië, was deze termijn wel te lang. Het leek er volgens de redactie op dat de commissie was ingesteld om tijd te winnen. $\mathrm{Na}$ twee jaar zou tiedereen wel vergeten zijn om welke reden de commissie eigenlijk ingesteld was. De regering zou dan uiteindelijk niets aan deze miscarriages of justice doen en dat zou een slechte zaak zijn. ${ }^{699}$ Mar ook de samenstelling van de commissie kon een reden zijn voor de verwachting dat er weinig zou gebeuren. Een conservatief georiënteerde commissie zou slechts weinig doeltreffende aanbevelingen doen.

Op 29 november 1991 kondigde de commissie aan dat een onderzoekprogramma opgezet zou worden waarbij in 22 deelprojecten voorbereidend werk verricht zou worden voor het uiteindelijke rapport. ${ }^{700}$ Op basis van

698. $\rightarrow$

Research Fellow of Trinity College; Sir Robert Bunyard, HM Inspector of Constabulary; Sir John Cadogan, Professor of Chemistry; John Gunn. Professor of Forensic Psychiatry; Sir John May heeft in 1989-1990 onderzoek verricht maar de omstandigheden van de Guildford en de Woolwich-zaken. H.C. 556, H.M.S.O., July 1990. Yve Newbold, Solicitor; Usha Prasha, Civil Service Commissioner en member of Lord Chancellor's Advisory Committee on Legal Education and Conduct; Anne Rafferty, Barrister; Sir John Wickerson, Solicitor; Sir Philip Woodfield. Staff Counsellor for the Security and Intelligence Services; Michael Zander, professor of Law, Solicitor.

The Royal Commission on Criminal Justice, 1993, p. 238-239.

699. Editorial, "Unappealing". New Law Journal, March 22 1991, p. 373.

700. De titels van de projecten zijn: Interviews with suspects outside the police station, The efficacy of different methods for preparing the recond of interviews with suspects, The exercise of the right of silence, Legal advice to suspects in custody and the right to silence, The supervision of police investigations, The superwision of investigations. The inwestigations of serious fraud cases, the work of forensic medical examiners in relation to the operation of the criminal justice system. The identification of vulnerabilities in suspects being interviewed by the police, Devising and piloting a revised version of the "notice to detained persons", Expert forensic evidence in the criminal process, The ability to challenge DNA ewidence, Directed and ordered acquittals in the Crown Court, Information and" advice for prisoners about grounds for appeal and the appeal process, Review of the provision of legal advice on appeal and the powers of the Court of Appeal, en The Crown Court study. The Royal Commission on Criminal Justice, Press Release: Royal Commission on Criminal Justice sets up Research Programme, 29 november 1991 . Op grond van deze 16 projecten zijn 22 rapporten geschreven. Royal Commission on Criminal Justice, 1993, p. 254-255. 
rapporten van deze deelprojecten zou medio 1993 het eindrapport van de commissie verschijnen hetgeen ook daadwerkelijk is gebeurd.

Drie van deze deelonderzoeken betreffen het toezicht op de politie bij het opsporingsonderzoek. Eén onderzoek gaat in op de beroepsprocedure en de werwijzingen van de minister naar de Court of Appeal. De overige deelonderzoeken hadden in het algemeen meer het verhoor van de verdachte, de rechten van de verdachte, deskundigen in de procedure, bewijsvraagstukken en vrijspraken bij de Crown Coun tot onderwerp.

Tregilgas-Davey hoopte in zekere mate dat de commissie tot de aanbeveling kwam dat de regering zou opteren voor het continentale model wan het strafrechtsysteem: het gematigd inquisitoir systeem. ${ }^{701}$ Het ging er volgens hem niet alleen om dat het recht zegeviert, maar dat ook het publiek onvoorwaardelijk het gevoel krijgt dat recht geschiedt. Volgens Steyger en Forder werd de kern van het probleem door de vorm waarin de opdracht van de commissie werd gegoten, niet aangepakt. Het functioneren van de politie en de CPS zou onvoldoende worden onderzocht. ${ }^{702}$ Men pleitte zelfs voor een nieuwe (permanente) Royal Commission on the Police. ${ }^{\text {jos }}$ De politie lijken steeds interventie nodig te hebben.

\subsection{The Royall Commission on Criminal Justice}

'I had assumed in my naive way that the recammendations put forward by the Royal Commission set up to prevent miscarriages of justice might contain the odd recommendation that might prevent a miscarriage of justice. I could nor find one. ${ }^{\text {mos }}$

\subsubsection{Doelstelling}

De Royal Commission on Criminal Justice had de opdracht voorstellen te doen tot het wijzigen van het strafreclntsysteem. Op 6 juli $1993 \mathrm{kwam}$ het rapport van de commissie uit. Dit rapport bevat 352 aanbevelingen. Het is de vraag in hoeverre de voorgestelde wijzigingen het politieapparaat zullen beïnloeden en in hoeverre de commissie oplossingen heeft voor de hierboven beschreven problemen.

701. Tregilgas-Davey, 1991, p. 716-717; Ook de redactie van The Criminal Law Review verwachtte dat het onderzoek voor een groot deel zal gaan over de discussie tussen een inquisitoir en een accusatoir strafproces; Editorial, 1991, p. 490. Zie eveneens Cooper, 1994, p. 381-382.

702. Steyger en Forder, 1991, p. 1055.

703. De Royal Commission werd niet voldoende geacht om alle problemen op te lossen. Editorial, 'Unappealing", 1991, p. 373.

704. Mackenzie, 1993, p. 1035. 
In de pers is er veel aandacht besteed aan het rapport van de commissie. $^{705}$ Het rapport is van verschillende kanten teleurstellend ontvangen. ${ }^{70}$ Er was wan verschillende kanten kritiek te horen op de doelstelling. van de staatscommissie. ${ }^{70 \%}$ De regering zou de kans gegrepen hebben om de staatscommissie dingen te laten uitzoeken die volstrekt voorbijgaan aan de oorzaak van het instellen van de staatscommissie. Een voorbeeld hiervan is het onderzoeken of het zwijgrecht van verdachten niet better opgeheven kan worden. Een dergelijke bepaling zou de rechtspositie van de verdachten nog meer verzwakken. In ieder geval is de opdracht van de commissie zo ruim geweest dat men gemakkelijk uit het oog verliest waarom de staatscommissie in het leven is geroepen en warom de commotie in de eerste plaats ontstaan is. ${ }^{70 i 8}$

Dit laatste is ook het grootste kritiekpunt van Wells in Criminal Justice in Crisis. ${ }^{709}$ Volgens haar had de commissie meer aandacht moeten besteden aan de verschillende miscarriages of justice omdat deze juist de reden waren voor het instellen van de commissie. ${ }^{710} \mathrm{De}$ commissie had niet voorbij mogen gaan aan de sociale en politieke contexten, waarin de gebeurtenissen plaats hadden gevonden. Met andere woorden de commissie had een totaalbeeld moeten maken van de gebeurtenissen en ervan wit moeten gaan dat tengevolge van het bestaande systeem fouten zijn gemaakt die dringend verbeterd moesten worden. ${ }^{71}$ Een soortgelijke mening is ook Rose toegedaan: 'Yet in the old regime's defeat lay an unprecedented opportunity for renewal and reform. Criminal justice wasn't working, but the time had come to ask why, and to put it right. This chance has not been raken, and the failure to do so is turning crisis into collapse. At the heart of this process is a failure of analysis. ... It follows that the crisis cannot be resolved by legislative tinkering: by lurches in the direction of either due process or crime control. It requires a radical reappraisal of both the system's institutional structures, and its underlying philosophy. 712

705. Zie The Guardian, The Times, The Independent en NRC Handelsblad van 7 juli 1993.

706. Bridges en McConville, 1994; Lacey 1994; Wells, 1994; Hillyard "1994, p. 6970.

707. Zie 0.a. Bridges en McConville, 1994, p. 5-6.

708. Vgl. Mackenzie, 1993, p. 1035, voor een kritisch geluid over de Royal Commission; Enright, 1993, p. 1023; zie ook Brants, 1994, p. $39-40$ en Bridges en McConville, 1994, p. 5-9.

709. McConville en Bridges, 1994.

710. Zie ook Hillyard, 1994, p. 71.

711. Wells, 1994, p. 51-52. Deze mening wordt gedeeld door enkele andere auteurs in Criminal Justice in Crisis.

712. Rose, 1996 , p. $310-311$. 


\subsection{3 .2 "We will be back here in ten years" time. ${ }^{.713}$}

Het voorkómen van miscarriages of justice lag aan de basis van de commissie. ${ }^{7 / 4}$ De minister van het Home Office, Michael Howard, stelde echter wast dat er niet alleen een miscarriage of justice is als een persoon (jarenlang) onschuldig gestraft wordt maar ook als een schuldig persoon vrijgesproken wordt. ${ }^{715}$ In dit geval wordt natuurlijk voor een belangrijk deel de reikwijdte van het onderzoek veranderd. De woorstellen die de commissie doet zijn dan ook zeer uitgebreid en hebben op een zeer groot gebied betrekking. Er wordt niet alleen geadviseerd met het oog op het voorkómen wan miscarriages of justice, maar ook met het oog op bezuinigingen. In plaats van de rechten en de positie van de verdachte veilig te stellen wordt door de commissie juist voorgesteld bepaalde rechten niet meer automatisch toe te kennen aan de verdachten zoals het recht om voor een jury gebracht te worden. ${ }^{16}$ Daarnaast zou volgens de voorstellen de verdediging verplicht moeten worden haar zaak volledig op tafel te leggen woor de terechtzitting begint. Wanneer dit niet gebeurt, zou dit door de rechter aan de jury negatief uitgelegd worden. Door deze aanbeveling kan het zwijgrecht aangetast worden. Bovendien heeft de commissie voorgesteld om bekennende verdachten te belonen met een lagere straf. Hoe eerder een verdachte in een procedure bekent, hoe lager de strafmaat. ${ }^{717}$

\subsubsection{De politie}

In the years since the Guildford appeal, the concern of public discourse has shifted away from miscarriages of justice. Today the principal focus of concern is the discharge or acquittal of factwally guilty defendants. Cheered on by the tabloid press, Police Commissioner Condon warns that when guilty men go free, police officers may be tempred to close the legal loopholes by indulging in their own criminal acts, by practising "noble cause corruption". Meamwhile, ebbing

713. Michael Mansfield, $Q C$ in The Times, 7 July 1993, p. 5.

714. Zie hierover ook Zander, lid van de Royal Commission, 1993, p. 1338.

715. The Independent, 7 July 1993. p. 1; zie ook Royal Commission on Criminal Justice, 1993 , p. $2-3$.

716. In aambeveling 114 van de Times, p. 35, van 7 juli ' 93 staat dat in either way offences de verdachte niet meer zomaar kan kiezen voor een jury. Hier is veel ophef over. Tot nu toe kan een verdachte aangeven of hij voor een magistraat of voor een jury bij de Crown Court wil verschijnen. Het voorstel van de commissie stelt paal en perk aan dit recht, door criteria te formuleren.

717. The Times, 7 July 1993, p. 4. De organisatie JUSTICE vreest dat :'... the invocent would ... come under pressupe to plead guily ... The proposal would "subly undermine the presumption of innocence in the criminal justice system"." Zie The Independent, 7 July 1993, p. 7. 
respect for the rule of law and the rise of wigilantism indicate a dangerous weakness in the State and civil society. "718

Al voor het uitbrengen van het rapport werd gespeculeerd wat de commissie over bepaalde zaken zou kunnen adviseren. Sir Peter Imbert, tot begin 1993 commissioner van de Metropolitan Police, heeft een duidelijke mening over het bekendmaken van all het bewijsmateriaal in een vroeg stadium. Hij is van mening dat er niet teveel naar de rechten van de verdachte moet worden gekeken. Andere belangen kunnen minstens zo groot of zelfs groter zijn. Volgens hem is de weegschaal teveel overgeheld naar de kant van de verdachte. 'I think the pendulum has swing so far the other way now there is a danger where a number of cases we are pressing could be put before the court but are not put before the court because one is unable to disclose $e^{719}$ the source of that information for fear that person might indeed then be executed or dealt with. I think also it impacts in some of these cases on other police enquiries going on. If that disclosure is too soon there will be other suspects who will not be arrested. Also the integrity of technical resources must also be protected. I think also the confidentiality of complainants must be protected, although I believe it is absolutely right to disclose all relevant material. I think the pendulum has swung so far the other way if we are not careful it will impact on our ability to bring people before the courts who should be brought before the courts. ${ }^{720}$

Zijn opvolger Paul Condon is voor een belangrijk deel dezelfde mening toegedaan, al geeft hij toe dat de politie als organisatie geen eisen aan de commissie of aan de regering kan stellen voor de manier waarop het systeem geregeld zou moeten worden. 'My personal opinion is that the balance is too heavily in favour of the accused and not sufficiently in favour of society protecting itself and so I would like to see the Committee looking at issues such as what has been described in shorthand as the right to silence. We now have some ludicrous rules on disclosure and I think we are actually reaching a point where it is going to be almost impossible in some cases to deal with professional criminals because of the rules on disclosure. We will. have to abandon prosecutions rather than expose informants and surveillants. ${ }^{" 72 !}$ Op de opmerking dat deze regels er juist zijn om miscarriages of justice tegen te gaan, reageert Condon als volgt: 'Yes, but it is for the Royal Commission to look at the balance we are given, but if you are asking

718. Rose, 1996, p. 310.

719. Alle documenten moeten boven tafel komen.

720. De tegenaanval van Sir Peter Imbert, in: Home Affairs Committee, Policing, 16 December 1992, p. 9.

721. Mr. Paul Condon, in: Home Affairs Committee, Policing , 24 March 1993, p. 27. 
me at this point how I feel about the balance. I feel it is heavily weighted in favour of the accused at the expense of society protecting itself against professional criminals." 722

Wat wordt nu expliciet door de commissie voorgesteld op het gebied van de politie? Er zijn voorstellen die betrekking hebben op foulllering en identificatie, op de aanwezigheid van een advocaat tijdens het verhoor van de verdachte, op de behandeling van slachtoffers en op klachten.

Volgens de voorstellen zou de verdediging in een vroeg stadium inzage moeten hebben in getuigenverklaringen, waarbij een beschrijving van de verdachte gegeven wordt. Van identification parades zou een foto-sessie of een video-opname gemaakt moeten worden. De bevoegdheden van de politie om lichaamseigen, maar niet intimate, materiaal van de verdachte zonder toestemming van de verdachte (af) te nemen worden uitgebreid. Hierbij moet gedacht worden aan o.a. het haar en het speeksel (voor DNA-onderzoek). Het nemen van een tandafdruk is wel intimate. Het weigeren van medewerking aan een dergelijke afname bij een niet ernstig feit kan gebruikt worden als bewijs. De politie moet de verdlachte in staat stellen na het bekend worden van de aanklacht een (gratis) advocaat te consulteren. Na het bekendmaken van de aanklacht mag de verdachte verhoord worden, mits de cautie gegeven is en na consultatie met zijn advocaat. Computer-systemen zouden aangelegd moeten worden woor vingerafdrukken. Er zou een aparte dienst moeten komen, een help-line, war klachten rechtstreeks aan de inspecteurs van het Home Inspectorate gemeld kunnen worden. De behandeling wan slachtoffers dient verbeterd te worden. Daartoe kunnen agenten interview-training krijgen. Agenten zouden ook geoefend moeten worden in het vermijden van de meest voorkomende fouten. Bij het beoordelen van het werk moet de kwaliteit voorop staan en niet het aantal aanhoudingen of veroordlelingen ${ }^{723}$

Over het algemeen kumnen agenten tevreden zijn met de aanbevelingen die door de commissie gedaan ziju. ${ }^{724}$ Enkele aanbevelingen die het werk van de agenten kunnen bemoeilijken, zoals solicitors in de gelegenheid stellen videobanden van de verhoren te laten bekijken, zullen in de praktijk niet altijd haalbaar zijn en derhalve geen wezenlijke bedreiging voor de politie vormen. Immers, niet alle solicitors zullen voldoende tijd en moeite hebben

722. Mr. Paul Condon, in: Home Affairs Committee, Policing, 24 March 1993, p. 27.

723. Times, 7 July 1993, p. 35.

724. Zie ook Lensing, 1994 , p. 568 . 
om bij aankomst op het bureau éen of twee uur durende video's te bekijken? ${ }^{725}$

\subsubsection{Afsluitende opmerkingen}

De aambevelingen van de commissie zijn geen echt opzienbarende voorstellen. Zander verklaarde dat de opdracht die de Royal Commission van de regering kreeg niet gericht was op het voorkomen van miscarriages of justice. De taak was om naar het gehele strafrechtsbestel te kijken. ${ }^{726}$ In feite kreeg de commissie drie opdrachten. De specifieke taakomschrijving luidde: "to examine the effectiveness of the criminal justice system in England and Whales in securing the comviction of those guilty of criminal affences and the acquittal of those who are innocent, having regard to the efficient use of resources..' Binnen deze taakomschrijving was het onderzoek naar het woorkómen van miscarriages of justice een klein onderdeel. Er moest door de commissie niet alleen gekeken worden naar manieren om te voorkomen dat onschuldigen veroordeeld worden, maar ook dat schuldigen wel veroordeeld worden. Ook dat laatste werd namelijk door de regering opgevat als een miscarriage of justice: als een schuldige ten onrechte niet veroordeeld werd. ${ }^{727}$ Zander vond het dan ook niet juist dat de commissie zoveel kritiek kreeg. De kritiek zou veeleer moeten uitgaan naar de regering die de commissie de opdracht had gegeven. ${ }^{728}$ Bestuderen we echter de Engelse kamerstukken dan valt er zonder twijfel uit af te leiden dat men ervan mag uitgaan dat het voorkómen van miscarriages of justice de voornaamste opdracht van de commissie was. ${ }^{729}$ Zander was van mening dat de miscarriages of justice voortgekomen zijn door 1) menselijke fouten en 2) door wetenschappers achtergehouden bewijs. Geen enkel systeem kan menselijke fouten voorkomen. Daarom zijn volgens Zander de aanbevelingen ook niet

725. Vgl. Hilliard, 1993, p. 1036.

726. Zander, 1993, p. 1338.

727. Dit is een politiek gebruik van terminologie: er zijn twee soorten miscarriages: onschuldigen die gestraft worden en schuldigen die vrij zijn.

728. Ibidem; zie ook Zander, 1993, p. 1365, waarin hij stelt dat voor zover men dacht dat de commissie zou trachten het systeem zodanig te wijzigen dat er geen miscarriages of justice meer zouden voorkomen, dat deze "expectations were unrealistic".

729. Mr. Kenneth Baker (Secretary of State for the Home Department) bij de aankondiging van de instelling van een Royal Commission on Criminal Justice in het House of Commons: 'We believe, however, that it is now necessary to undertake a review of the criminal justice process as it at present stands, taking full account of recent reforms. The aim of such a review will be to minimise so far as possible the likelihoad of such ewents happening again." 187. H.C. Deb., 6th Ser., kolom 1109; zie ook Nobles en Schiff, 1994, p. 42. 
radicaler geworden in de zin dat er ingrijpende voorstellen zijn gedaan op het gebied van het strafproces. ${ }^{730}$

Op dit punt ben ik het geheel oneens met Zander. Ik wil me hier dan ook aansluiten bij McConville en Mirsky die stellen dat de commissie tot bovenstaande conclusie is gekomen zonder enig onderzoek naar de (individuele) gevallen te doen. ${ }^{731} \mathrm{Had}$ de commissie dat wel gedaan, dan waren bepaalde aanbevelingen zeer zeker anders geformuleerd of niet zo oppervlakkig geweest als het verschaffen van pen en papier aan juryleden (hetgeen op zich natuurlijk ook een bepaalde waarde heeft). Dan was de commissie zaken tegengekomen als politiemisbruik tijdens verhoor, de afbreuk van het onschuldbeginsel etc. Wat dit betreft is het derhalve een tekortkoming van de commissie dat de praktijk niet daadwerkelijk getoetst is of an de orde gekomen is.

Als positieve aanbeveling kunnen we de oprichting van een onafhankelijk tribunaal - Criminal Case Review Authority - beschouwen, dat voortaan vermeende miscarriages of justice zal gaan onderzoeken. ${ }^{732}$ Dit voorstel is afkomstig van de Police Complaints Authority. ${ }^{733}$ Wadham van de organisatie Liberty is van mening dat een dergelijk tribunaal zo snel mogelijk opgericht moet worden. Liberty bijwoorbeeld heeft zo'n 200 gevallen onderzocht waarin sprake is van een unsafe veroordeling. ${ }^{734}$ Wadham geeft nog aan dat het rapport in zekere zin inconsistent is. In de IRA-zaken zijn er gevallen geweest waarin niet alle documenten ter inzage zijn gelegd aan de verdediging. $\mathrm{Nu}$ geeft de commissie in haar rapport aan dat in het geval dat de politie op verzoek van de CCRA onderzoek verricht, de berichtgeving hierover niet aan de verdediging overgelegd hoeft te worden! ${ }^{735}$ Een struikelblok blijft helaas nog bestaan: the Court of Appeal. De laatste jaren heeft dit hof aangetoond zeer terughoudend te zijn in het toegeven dat er een fout is gemaakt. ${ }^{736}$ Het is de vraag of het voldoende is om een CCRA in het

730. Zander, 1993, p. 1341

731. McConville en Mirsky, 1993, p. 1446-1447.

732. Aanbeveling 331, Royal Commission on Criminal Justice, 1993, p. 217; Times, 7 Jully 1993. p. 4: Bridges en McConville, 1994, p. 22-23.

733. Police Complaints Authority, 1992, p. 28.

734. Wadham, 1993, p. 1650.

735. Wadham, 1993. p. 1651: Royal Conmission on Criminal Justice, 1993, p. 186187.

736. De Court of Appeal is een slachtoffer van zijn eigen ideologie: "best justice system in the world". Een dergelijk systeem kan natuurlijk geen fouten maken. Voor elk systeem zal het overigens moeilijk zijn eigen fouten toe te geven. $\mathrm{Vgl}$. Enright, 1993. p. 1024 . 
leven te roepen zonder op wetgevend gebied iets te wijzigen bij dit Court of Appeal. ${ }^{737}$

De commissie heeft even overwogen of de overgang van het adversarial naar het inquisitoir stelsel een haalbare kaart zou zijn. Al vrij snel heeft men dit idee laten varen. De reden hiervoor was dat men in de commissie tot het besef kwam dat veel (sic!) continentale landen aan het denken waren de overstap te maken naar het Engelse adversarial systeem. Als voorbeeld noemt Zander Italie. ${ }^{738}$ Daarnaast werd de op zich goede opmerking gemaakt, dat het niet altijd mogelijk is kenmerken van het ene systeem zonder problemen over te brengen naar een ander systeem.

De commissie heeft getracht een evenwicht te vinden tussen '... the need to convict the guilty, the need not to convict the innocent and due econo$n y y .{ }^{739}$ Van bepaalde kanten is het commentaar gekomen dat de commissie iets te veel aandacht heeft geschonken aan kostenbesparende maatregelen. ${ }^{740}$ Minder juryzittingen en het inzetten van meer magistrates zijn daar voorbeelden van. Dat laatste heeft ook nog het voordeel dat er meer veroordelingen zullen komen hetgeen goed is voor de statistieken en geld in het laatje kan brengen. ${ }^{741}$

Wat zal de regering nu met de voorstellen gaan doen? Welke voorstellen zullen overgenomen worden in een wetsontwerp? Deze vragen houden op dit moment de juristen en de praktijkmensen bezig in Engeland en Wales. Kopstukken in het politieapparaat onthouden zich niet van commentaar op de voorstellen. Veel van de voorstellen kunnen immers van invloed zijn op het functioneren van de politie.

\subsubsection{Conclusie}

De publiciteit rond de IRA-zaken maakt duidelijk dat deze zaken veel ophef veroorzaakt hebben en de politie - maar ook de rechterlijke macht - een slechte naam bezorgd hebben, in binnen- en buitenland. ${ }^{742}$ Bij deze zaken is het echter niet gebleven. Ook bij niet-IRA-zaken is de politie niet altijd

737. Zou het niet te overwegen zijn om voor alle zaken automatisch de toegang tot de Court of Appeal toe te staan, zoals in Nederland gebeurd bij de Hoge Raad? Zou de overgang naar een verlofstelsel in Nederland, zoals al voorgesteld is, een positieve bijdrage leveren aan cen fair trial?

738. Zander, 1993, p. 1341.

739. Zander, 1993, p. 1338.

740. Padfield, 1993, p. 1023; Enright, 1993, p. 1023.

741. Enright, 1993, p. 1024.

742. Van het Bobby-imago dat de politie bezat, is weinig over. 
even nawwkeurig en wetsgetrouw bezig geweest. Wat dat betreft hebben de 'IRA'-zaken een sneeuwbaleffect teweeg gebracht. Met name de politie in West-Midlands is op dit moment nog onderwerp van veel politie-onderzoek. We kunnen derhalve, om in de termen van Sherman te blijven, van een schandaal spreken. Het was derhalve voor de regering duidelijk dat 'iets" gedaan moest worden. Vandaar dat er in 1991 een Royal Commission werd ingesteld die moest onderzoeken of het strafproces hervormd diende te worden. De commissie had bepaald geen makkelijke taak.

Veel hing af van de vraag hoe commissie haar taak zou opvatten. Drie van de zestien deelprojecten van de Royal Commission gingen in op de problematiek van de politie, terwijl andere projecten nagingen in welke mate fouten vroegtijdig door het strafproces opgespoord konden worden. De commissie had informatie opgevraagd over strafrechtssystemen in het buitenland en commentaar of advies gevraagd van een ieder. ${ }^{143}$ De aanbevelingen die in het rapport van de Royal Commission gedaan werden, zouden de problemen deels kunnen doen verdwijnen. De commissie is echter de regering nog niet, en we moeten maar afwachten hoever de regering wil gaan met het veranderen van het systeem.

Toch zien we ook hier duidelijk de dynamiek van 'schandaal' en (de wil tot) 'hervorming'. In het volgende hoofdstuk wil ik op deze theorie terugkomen in het licht van de vijf voorbeelden die ik hier behandeld heb.

743. Royal Commission on Criminal Justice, 29 November 1991. 


\section{Analyse}

\subsection{Inleiding}

In deze studie zijn in de voorgaande hoofdstukken een vijftal casus aan de orde gekomen die verband houden met het controle- en onafhankelijkheidsvraagstuk van de politie in Engeland en Wales. Voornamelijk zien we bij die casus de problemen en/of de gevolgen die voort kunnen vloeien uit het ontbreken van een verantwoordingsplicht. Daar draait het in deze studie ook om. In dit gedeelte wil ik de gebeurtenissen tegen de achtergrond van de theorie van schandaal en hervorming plaatsen die $i k$ in het eerste deel beschreven heb. Daarmee wil ik aantonen dat er een dynamiek op te merken valt bij het vóórkomen van specifieke gebeurtenissen.

In het eerste hoofdstuk heb ik kort verwezen naar het boek Folded Lies van Reisman over twee mogelijke strategieën van de overheid bij een publieke reactie op de aanwezigheid van bribery: reform en crusade. ${ }^{744}$ Deze twee strategieën komen volgens mij niet slechts bij omkoping en afpersing voor (hetgeen de kern van het boek van Reisman vormt), maar bij elk schandaal, of dat nu bestaat uit corruptie of een ander strafbaar of laakbaar feit. Aangezien in deze studie de hervormingsmaatregelen die de overheid genomen heeft na het bekend worden van een schandaal, aan de orde gekomen zijn, is het van belang na te gaan of deze hervormingen wel effectief genoemd kunnen worden in het licht van de theorie van Reisman. Vandaar dat ik hier deze laatste theorie nog eens aanhaal.

In dit hoofdstuk wil ik het derhalve hebben over de rol en de betekenis die een hervorming kan hebben op het veranderen van de status quo. Een hervorming in de vorm van een nieuwe wet kan namelijk zowel nauwelijks als zeer grote gevolgen hebben.

Daarna wil ik ingaan op het door mij geformuleerde uitgangspunt, namelijk de problemen die ontstaan tengevolge van het ontbreken van verantwoordingslijnen van de politieorganisatie naar maatschappij en politiek. Bij de behandeling van deze probleemstelling komen enkele subvragen naar boven. Wat betekent de onafhankelijkheid van de politie? Is de politieorganisatie wel onafhankelijk volgens haarzelf en de politiek? Zou er een meer uitgesproken vorm van politieke verantwoordelijkheid moeten komen? Geniet de Britse politie nog wel het vertrouwen van de burgers? Kunnen op dit gebied nieuwe ontwikkelingen verwacht worden?

744. Reisman, 1979. 
Allereerst volgt een nadere toelichting op de theorie van Reisman. Vervolgens worden in het kort de vijf besproken casus geanalyseerd. Daarna komen bovengenoemde vragen aan bod. Het hoofdstuk wordt afgesloten met een conclusie en enkele vragen.

\subsection{Reisman}

In hoeverre kan een wijziging in wet of beleid daadwerkelijk verandering brengen in een bestaande situatie? In welke mate is een wijziging oftewel een hervorming effectief en vergaand genoeg? Is het wel altijd de bedoeling van de overheid om aan de bestaande situatie een einde te maken? Op deze vragen tracht het boek van Reisman, Folded Lies, een antwoord te geven.

\subsection{1 'Myth system' en 'operational code'}

Reisman maakt in zijn boek een onderscheid tussen een 'mythe systeem' en een 'operationele code' in een samenleving en een organisatie. In elke maatschappij is er een geheel van regels en normen te vinden waar de bevolking zich aan houdt of dient te houden. Vaak is dat gecodeerd in strafwetten of andere formele wetgeving. Dit wordt het 'mythe systeem' genoemd ${ }^{745}$ Het handhaven van de openbare orde en de opsporing van strafbare feiten in een maatschappij kunnen echter problemen geven en uiterst kostbaar zijn, vooral als er veel regels en normen zijn. De (vervolgende instantie van de) overheid kan er derhalve toe overgaan bepaalde strafbare feiten niet meer zo stringent op te sporen, omdat de opvatting heerst dat dit de hele maatschappij ten goede komt. Dit wordt een selectief opsporingsbeleid genoemd. Logischerwijs wordt een (groot) deel van de bevolking zich ervan bewust dat veel normen en regels niet altijd even effectief door de overheid gehandhaafd worden. Bepaald gedrag bijwoorbeeld in strijd met de regels wordt geduld indien het doot een bepaalde bevolkingsgroep vemoond wordt. Hetzelfde gedrag door een andere groep wordt echter wel aangepakt. Een inwoner die zich daarvan bewust is en hiervan gebruik (misbruik) maakt, handelt alcus naar de operationele code. ${ }^{746}$ Tussen beide 'systemen' bestaat een spanning. Meestal is de overheid niet (erg) genegen het bestaan van $z 0^{\prime \prime} \mathrm{n}$ operationele code toe te geven ${ }^{747}$ Men zal dit ontkennen door onder andere te verwijzen naar de discretionaire bevoegdheden van de vervolgende

745. Myih System. Reisman, 1979, p. 1, 16.

746. Operational Code. Reisman, 1979, p. 1, 16

747. Ook op andere terreinen kan er een verschil zijn tussen "mythe systeem" en "operationele code". Om een voorbeeld te geven. In Engeland en Wales werd vroeger ontkend dat er sprake was van plea bargaining, zoals in de Verenigde Staten van Amerika, toidat enkele onderzoekers aantoonden dat het wel degelijk bestond. 
instanties die immers de vrijheid hebben uit te maken of een strafbare handeling vervolgd wordt of niet. Het niet vervolgen van strafbaar gedrag maakt dat gedrag in het algemeen niet ineens wettelijk toelaatbaar. ${ }^{748}$ Valt er echter een tendens te bespeuren die wijst op de duidelijke aanwezigheid van een operationele code, dan bestaat de mogelijkheid dat de spanning tussen beide systemen naar buiten komt. ${ }^{79}$ Dit kan zich uiten in een schandaal. ${ }^{750}$

\subsubsection{Kruistochten en hervormingen}

Enkele personen ${ }^{751}$ en media zullen als gevolg van de aanwezigheid van de (afwijkende en illegale) operationele code veel ruchtbaarheid aan de zaak geven teneinde een reactie van de vervolgende instantie ${ }^{752}$ of van de overheid te bewerkstelligen. Het doel van deze actie is - bewust of onbewust het willen terugkeren naar het mythe systeem en het tegengaan van de operationele code. ${ }^{753}$ 'People who have identified' with, and put their faith in. government and have come to assume that government is indispensable to many of the values they demand will be ripe for a crusade when they think, realistically or not, that things are going very badly. I believe that the critical factor that accounts for the increased support necessary for popular crusades is a shared perception of societal crisis. "7s4 Een dergelijke "crusade' wordt door Reisman als volgt omschreven: 'It is a highly open and often ostentatious elite-initiated or elite-coopted campaign that may publicly humiliate or penalize some elite members but does not change the basic power structure, the composition of the elite, or their fundamental practices. ${ }^{753}$ Mensen of media die zo'n kruistocht starten zullen in de meeste gevallen natuurlijk wel een verandering van het systeem voorstaan, anders zou het nut van de verontwaardiging over een schandaal ver te zoeken zijn. Vaak wordt de actie overgenomen door de overheid. De overheid stelt zich dan tot doel ervoor te zorgen dat de waarden van en het geloof in het mythe

748. Reisman, 1979, p. 21.

749. Reisman, 1979, p. 7.

750. Vgl. het schandaal rond Oliver North in Amerika.

751. Als moral entrepeneurs of zedenprekers.

752. De politie in Engeland en Wales staat los wan de overheid. In Nederland zou men wel kunnen spreken van een instantie wan de overheid als men het ower de politie of het Openbaar Ministerie heeft.

753. Een voorbeeld van iemand die dergelijke acties initieerde is de heer Blackburn in de zaken R. w. Met. Police Comr, ex parte Blackburn (1968) $2 \mathrm{QB} 118 \mathrm{en}$ (1973) $Q B 241$, betreffende het naar zijn zeggen onvoldoende vervolgen van het gokken in gokhuizen en pornografie.

754. Reisman, 1979, p. 109.

755. Reisman, 1979, p. 96. 
systeem bevestigd wordt. Dit heeft vooral politieke betekenis in die zin dat het vertrouwen van de burgers in de overheid herwonnen wordt. De overheid is het in dit geval eigenlijk niet eens met de doelstelling van de kruistocht doch probeent door het memen van enige maatregelen de burgers het idee te geven dat er wel iets gedaan wordt aan het bestaan van de operationele code. ${ }^{756}$

Daarnasst kan de overheid van mening zijn dat er wel degelijk iets fundamenteel veranderd moet worden. In dat geval zien we dat de overheid met echte hervormingen voor de dag komt. ${ }^{757}$ Een hervorming heeft ten doel het veranderen van de bestaande situatie teneinde het mythe systeem te herstellen. De hervormingen richten zich dan voornamelijk naar degenen (operators) die de operationele code toepassen.

Deze laatsten zullen er alles aan doen om te redden wat er te redden valt. "Their first defense is an attempt to quash the campaign. If the effort fails' and popular dissatisfaction mounts, operators seek to transform it into a crusade by deflecting public dissatisfaction into symbolic activity; if legislation must issue, it is simulated or imperfect. Under cover of this noisome but essentially inconclusive activity, elite positions may be maintained and the old practices continued. ${ }^{758}$ In dat geval zal een hervorming weinig uithalen en zelfs falen. Over het algemeen heeft een hervorming een dergelijk gevolg niet en zal er wel degelijk iets veranderen.

\subsubsection{Resultaat}

De politiek moet in de meeste gevallen de maatregelen nemen die noodzakelijk zijn geworden door de ophef rondom het bekend worden van een operationele code. Algemeen bekend is dat de politiek niet snel werkt. Nieuwe wetgeving vraagt vaak jaren voorbereidingstijd. In de tijd dat een maatregel in de politieke molen zit kunnen doelstellingen en beleid ondertussen gewijzigd worden. Ook aan de maatregel kan tijdens het politieke proces zoveel veranderd worden dat het na invoering niet meer effectief de operationele code te lijf kan gaan. 'Because campaigns such as these are a series of skirmishes rather than a single decisive confrontation, only over time is it possible to conclude whether they were merely brief interruptions or real changes in the operational code. Even if passed, "reform" legislation, that is, legislation actually intended to change the operational code, is not equivalent to reform, for it may be blunted by operators at lower lovels of the bureaucracy who may prevent or indefinitely posipone the drafting of rules

756. Reisman, 1979, p. 96, 104-105.

757. Reforms. Reisman, 1979, p. 110-114.

758. Reisman, 1979 , p. 114 
or secondary, implementing legislation. If implementing machinery is actwalby created, it may be starved to death by an inadequate budget allocation or emasculated by the assignment of incompetents to positions of responsibility. ${ }^{n 79}$ Hieruit volgt dat het niet altijd gemakkelijk is vast te stellen of op langere termijn een maatregel louter een symbolische kruistocht was of een echte hervorming. 'The final judgment can be made only years later, when it is possible to assess whether legislation has led to aggregate changes in targeted behavior. ${ }^{1760}$ Dan kan ook blijken dat de genomen maatregel die door de overheid als herworming bedoeld was achteraf slechts als een kruistochtfunctie heeft gediend. Deze constatering heeft tot gevolg dat het niet zonder meer mogelijk is te spreken van een hervorming als de gevolgen van de oude (vervangen) situatie nog altijd naar boven komen. Wanneer dat laatste het geval is kan er beter van een kruistocht gesproken worden. ${ }^{76 !}$

Het belang van een kruistocht moet niet over het hoofd gezien worden. Een kruistocht zou beschouwd kunnen worden als een afleidingsmanoeuvre. Er verandert in feite niets aan de situatie. Desalniettemin vervult het toch een functie. "While it may be deemed a failed reform from the perspective of the erstwhile reformer, it is a successful social operation from the standpoint of the threatened operator and all those who identified positively with those aspects of the operational code under attack. A crusade is successful when it reasserts the values of the myth system. Paradoxically, a failed reform may have few disrupting consequences. In contrast, a failed crusade is quite likely to mean the termination of certain norms within the myth system. ${ }^{7762}$

\subsection{De zes P's}

In het licht van bovenstaande theorie van Reisman kunnen we de gebeurtenissen en de wetswijzigingen nagaan die daarvan het gevolg zijn en die in dit boek beschreven staan. In alle gevallen zien we dat het bestaan en ontdekken van een operationele code geleid hebben tot verontwaardiging van het publiek. Lopen we de vijf casus na dan kunnen we constateren dat de oorzaak van de verontwaardiging een ruzie tussen politiekorpsen onderling of conflicten tussen burgers en politie waren. Voor de verdere bespreking maakt het niet uit hoe het schandaal ontstaan is. Alteen belangrijk is de vraag of en hoe de politie en de politiek gereageerd hebben op het schandaal.

759. Reisman, 1979, p. 11.4.

760. Reisman, 1979, p. 115.

761. 'Where the outcome of the new practice is substamially the same as before, the campaign is a crusade. A crusade is not a reform.' Reisman, 1979. p. 116.

762. Reisman, 1979, p. 116. 
Dat ex gereageerd is op de schandalen hebben we gelezen in de vorige hoofdstukken. Elk schandaal dat ik hier naar voren heb gebracht, heeft geresulteerd in een wetswijziging. Of de wetswijzigingen daadwerkelijk effect sorteerden is een verhaal apart. Elk schandaal doorloopt - zo zagen we -een bepaald schema. We kunnen bij elk van de vijf gebeurtenissen spreken van de zes $\mathrm{P}^{\prime} \mathrm{s}^{763}$ : problem, publicity, people, politics, policies en practices. $^{764}$ Deze zes $\mathrm{P}$ 's geven in het kort het traject aan waar het allemaal om draait: Er is een probleem - in onze gevallen een schandaal - dat door de media naar buiten wordt gebracht (publicity). Woordvoerders (moral entrepeneurs) en critici (people) reageren daar met verontwaardiging op. De overheid (politics) en de betrokken instantie komen door middel van (ideologische) debatten met een gewijzigd beleid (policies) en dit leidt dan tot een bepaalde manier van werken: de nieuwe praktijk (practices). Kern vraag is of deze praktijk wezenlijk verschilt met de manier van werken waar in eerste instantie kritiek op was. Met andere woorden is het 'gedrag' daadwerkelijk ten goede veranderd.

Wanneer we nu teruggaan naar de vijf casus die ik in dit boek besproken heb, dan is het meest opvallende dat veel van de voorgestelde wetswijzigingen geen echte hervormingen waren in de zin van de theorie van Reisman doch slechts kruistochten - gewild of ongewild. De problemen, die de aanleiding vormden voor de hervormingen, vloeiden m.i. voort uit een te grote onafhankelijkheid - dus geen verantwoondingsplicht - van de politie. Aan deze onafhankelijkheid is echter nooit getornd. ${ }^{765}$ Steeds werd het probleem niet tot op de bodem aangepakt waardoor een nieuw voorval weer gemakkelijk kon ontaarden in een schandaal. In de vijf gevallen kan ik geen echte hervorming herkennen, maar ik kan evenmin in alle gevallen spreken van een gelukte kruistocht. Met name het doel om het vertrouwen in het systeem terug te winnen van de bevolking werd slechts ten dele en vaak tijdelijk gehaald.

\subsubsection{Causes célèbres}

In de politiekorpsen van Cardiganshire en enkele andere streken in Engeland en Wales kwamen in de jaren ' 50 interne problemen naar buiten die de politie bij de bevolking geen goede naam bezorgden. De media benadrukten in hun verslaggeving het verslechteren van het vertrouwen van de burgers in de politie. Het bleek dat de problemen ook niet via overleg tussen hoofdcommissarissen en politiecommissies opgelost konden worden. De politiek

763. $\mathrm{Vgl}$. de zeven ijzeren D's van Blaaw w, 1991, p. 36 (dames, drank, dubbeltjes, drugs, dalven, dobbelen en dirty tricks).

764. Naar een idee van Maurice Punch.

765. Het systeem verdedigt zichzelf. 
in Londen greep in vanwege onvrede over het lokale onvermogen om deze situatie op te lossen. Een nieuwe, duidelijke structuur was nodig waarin de bevoegdiheden van de verschillende organen die met de politie te maken kregen helder en onomstreden omschreven zouden worden. Het resultaat was de nieuwe politiewet van 1964 die zes jaar na het laatste incident in werking getreden was. Achteraf bleek dat die wet de verhouding tussen burgers en politie niet verbeterd had. Die verhouding kwam uiteindelijk niet meer ter sprake. De wet gaf alleen duidelijkheid in de interne structuur van de politieorganisatie.

\subsubsection{De dood van Blair Peach}

Ook in deze casus zagen we dat de invoering van een nieuwe klachtenprocedure in 1976 niet geleid heeft tot het verkrijgen van vertrouwen van de burgers in de politieorganisatie. Naar aanleiding van de dood van de heer Peach in 1979 waren er kamervragen gesteld over de onafhankelijke afhandeling van klachten door de Police Complaints Board. Het was zonneklaar dat men niet tevreden was met de bestaande procedure. Het heeft toen tot de inwerkingtreding (1986) van de PACE 1984 geduurd, voordat de procedure gewijzigd werd. Maar ook deze wet heeft niet de rust en het vertrouwen gebracht. Men stond en staat nog steeds zeer wantrouwend tegenover een organisatie die zichzelf controleert. Immers, al is de Police Complaints Authority onafhankelijk van de politie, het feitelijk onderzoek naar de gegrondheid van een klacht geschiedt nog altijd door de politie zelf. Het kleine aantal gegrondverklaringen van een klacht heeft er mede toe bijgedragen dat mensen met een klacht er tegenwoordig eerder toe overgaan om een civiele procedure te beginnen dan dat ze gebruik maken van de klachtenprocedure van de PACE 1984.

\subsubsection{Brixton}

In Brixton ging het eveneens over de verhouding tussen politie en burgers, in dit geval kleurlingen. De rellen die in dit gedeelte van Londen uitbraken toonden aan dat het vertrouwen van jonge kleurlingen in de politie ver te zoeken was. De aanbevelingen die Scarman naar aanleiding van zijn onderzoek naar deze rellen deed, waren gericht op het verbeteren van die verhouding. De wet PACE 1984 had deels ook deze doelstelling overgenomen. Een speciaal wetsartikel (artikel 106 PACE 1984) zou er voor moeten zorgen dat burgers en politie in overleg met elkaar kwamen. Wat dat betreft stond de regering een echte hervorming voor agen. ${ }^{766}$ Dit is ook wel lo-

766. Ook hier geldt natuurlijk dat een wettelijke regeling miet altijd het gewenste resultaat tot gevolg heeft. Wat dat betreft geloof ik miet in de kracht van de wetgeving. 
gisch want het is voor een instantie, die orde en rust moet handhaven, niet prettig om zelf steeds geconfronteerd te worden met massale uitbarstingen van geweld en onvrede. ${ }^{767}$ Toch is door andere factoren van de verwezenlijking van de doelstelling weinig terecht gekomen, $m$.a.w. het viteindelijk terugwinnen van het vertrouwen is niet bereikt. Dit ideaal bleef een dode letter omdat door het veelvuldig vóórkomen van rellen in grote steden de politie overging op riot training, hetgeen een niet-vriendelijke manier van omgang met de bevolking op de voorgrond plaatste. ${ }^{768}$ Daarnaast is de militaristische manier van optreden tijdens de mijnstakingen in 1984-1985 oorzaak geweest van een slechtere verhouding van de politie met de onderste laag wan de bevolking.

\subsubsection{De Confait-case}

In deze zaak stond de politie als vervolgende instantie ter discussie. Kritiek was ontstaan over de onderyraging van enkele minderjarigen door de politie. Een Royal Commission kreeg de opdracht te kijken naar de opsporing en de vervolging van strafbare feiten. De commissie concludeerde dat deze twee taken gesplitst moesten worden. ${ }^{769}$ Als hervorming van het systeem werd voorgesteld een onafhankelijke Crown Prosecution Service in het leven te roepen. Dit blijkt achteraf ook geen succesvolle maatregel te zijn geweest. ${ }^{770} \mathrm{De} C P S$ heeft te weinig personeel en te weinig bevoegdheden om zelfstandig onderzoek te doen. Wat dat betreft is de dienst zeer afhankelijk van de politie. Wanneer we de CPS vergelijken met het Nederlandse Openbaar Ministerie (OM) dan zien we dat het OM sterker is en meer kan. De CPS beschikt niet eens over de mogelijkheden om het werk van de politie na te gaan. Nu is well door de wet de vreemde situatie geschapen dat aan de ene kant de Director of Public Prosecutions als hoofd van het CPS door het parlement ter verantwoording over het vervolgingsbeleid kan worden geroe-

767. Maar aan de andere kan is deze handelwijze van de regering, gezien mijn opmerkingen in de vorige noot, wel naïef.

768. Het beginnen met een tiot-traiming van politie-agenten valt samen met het premierschap van Margareth Thatcher.

769. Hierbij had men duidelijk niet het continentale voorbeeld woor ogen. Men wilde de functies van opsporing en vervolging niet vermengen. Ook de laatste Royal Commission is die mening nog toegedaan. Zie bijw. Royal Commission on Criminal Justice, 1993, p. 22, 69-72; Brants, 1994, p. 35.

770. Rose zegt over de huidige CPS: 'We need a transformed prosecution service. It must openate within the framework of formal constinutional rights, and be consritwionally accounuble:" 1996, p. 319. 
pen, maar dat anderzijds de politieagenten voor individuele gevallen aan niemand dan hun hoofdcommissaris verantwoording werschuldigd zijn. ${ }^{771}$

\subsubsection{Miscarriages of Justice}

In deze casus zijn enkele zaken aan de orde gekomen waarbij na soms vele jaren door de Court of Appeal uitspraken vernietigd werden, vanwege tekortkomingen van de politie bij haar opsporingsonderzoek die als zodanig in eerste instantie en de jaren daarna niet (h)erkend werden. Maar niet alleen de politie heeft fouten gemaakt. De miscarriages of justice lieten op verscheidene momenten in de strafrechrsprocedure door het politiële en justitiële apparaat gemaakte onjuistheden en fouten zien. In een schema ziet het proces waarlangs de Engelse verdachte het systeem moet doorlopen en waar fouten voor kunnen komen, er als volgt uit. In de rechterkolom zijn de onvolkomenheden weergegeven.

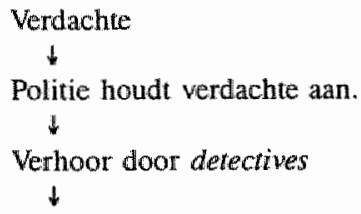

771. Afgezien yan het feit dat ze zich wanneer dat nodig is voor de rechter moeten verantwoonden.
Door speciale eenheden, bijv. Serious Crime Squad. In de West-Midlands is zo'n eenheid bij gebleken misstanden in de jaren " 80 geheel opgedoekt.

Legal aid lawyers: veelal jong en onervaren.

Controle door de eigen werkbaas hetgeen onvoldoende gebeurde.

Controle door local communities. Politiecommissies "kunnen het beleid wan het korps in de gaten houden, maar laebben over individuele gevallen niets te zeggen.

Ook op dit niveau zijn fouten gemaakt. zaken steunde enkel en alleen op hef forensische bewijs. Later bleek dat de testen waarmee het bewijs geleverd werd niet deugden. Het bewijsmateriaal in cen wan de IRA 
Rechterlijke macht

I

Hoger beroep

$\downarrow$

Home Secretary

$\downarrow$

Buitenparlementaire actiegroepen
De rol van de prosecution en de defence. De prosecution die feiten en dossiers achterhoudt. En de verdediging die onmachtig is om iets aan de wantoestanden te doen. Daarnaast het juridisch spel in de rechtbank, waarbij een jury overtuigd moet worden. Bovendien is er nog de rechterlijke macht die onwillig is misstanden toe te geven.

De onwilligheid van de rechters in hoger beroep om uitspraken in eerste instantie te vernietigen.

De terughoudendheid van de minister gebruik te maken wan zijn bevoegdheid ex art. 17 Criminal Appeal Act.

Watch-dog groups bijw. JUSTICE of Liberty. Deze groepen proberen de andacht te vestigen op facetten die in het proces fout zijn gegaan, maar hebben doorgaans pas na jaren succes. De actiegroepen hebben vaak de media of een woordwoerder nodig om een zaak met succes onder de aandacht van de politiek te brengen. ( $\mathrm{Vgl}$. de inzet. van parlementslid Chris Mullin voor de Zes van Birmingham, maar ook hij had pas na jaren succes)

Het resultat van deze schandalen was het instellen van een Royal Commission on Criminal Justice die tot taak had het bekijken van het gehele strafproces. Dus niet alleen de politie, maar ook de verdere strafrechtelijke procedure werd aan een onderzoek onderworpen. We hebben gezien dat er kritiek bestond op de opdracht van de commissie omdat daarin te weinig aandacht gevraagd werd voor de fase bij het politieapparaat. Men vroeg zich daarom ook af of de voorstellen van de commissie tot een echte hervorming zouden kunnen leiden?

\subsection{Politie en openheid}

In Engeland en Wales is men eind tachtiger jaren tot thet besef gekomen dat de problemen die hier behandeld zijn niet alleen toe te schrijven zijn aan de politie. Men is zich ervan bewust geraakt dat in het helle systeem fouten zijn 
gemaakt. Fouten kunnen optreden bij het politieverhoor, bij het onvoldoende controleren door de superieuren, bij het verkeerd gebruik van forensische testen, bij het achterhouden van bewijs op de zitting en door het niet toelaten van een hoger beroep vanwege een te rotsvast vertrouwen in de politie. Men ziet in Engeland in dat de geloofwaardigheid van het politieapparaat aangetast is. Er worden nu standard's gesteld waaraan het gedrag van agenten moet voldoen. Het doel van deze richtlijnen is om de werkwijze van de politie zichtbaarder en dus begrijpelijker te maken. Dit kan bereikt worden door openlijker op te treden en derhalve tegenover de burgers meer besef van verantwoordelijkheid te tonen. In de niewwe richtlijnen is onder meer bepaald dat alle stukken in een rechtszaak naar voren worden gebracht (disclosure), dat videotaping van verhoren plaatsvindt en dat agenten binnen vijf minuten na een melding van misdrijf of ongeval ter plaatse zijn. Deze maatregelem kunnen ervoor zorgen dat de burgers weer een groter vertrouwen in de politie krijgen. Immers, door deze open opstelling van de politie wordt het werk van de politie doorzichtiger en meer accountable "Het moet moeilijker worden voor de agenten misbruik te maken van regels en richtijnen. ${ }^{772}$ Wel denk ik dat de agenten onder grotere spanning komen te staan nu er zo duidelijk op het gedrag van hen gelet gaat worden.

\subsection{Pollitiek}

Snel handelen van de regering om via wetswijzigingen het rechissysteem (en daarmee de politie) te verbeteren is feitelijk onmogelijk. Actiegroepen en de eigen achterban in het parlement oefenen daarnaast druk uit op de regering. Ook het parlement waarvan de regering onderdeel is, heeft veelvuldig te maken met lobbying. Deze politiek heeft uiteindelijk toch een invloed op het politiebeleid ook al staat de politie formeel los van de politiek in Londen. Hieronder will ik dat verduidelijken.

772. Regels worden vaak bent and broken om bepaalde resultaten te bereiken of om bepaalde handelingen te verbergen. Om met Punch te spreken, men verwerfi "creativity in getting around rules." 


\section{PARLEMENT}

houdt zich bezig op drie terreinen:

control

legislation/policy

daarnaast heeft her parlemeni te maken met de:

\section{Party Politics}

die onder te verdelen is in:

\section{LEFT}

spreekt namens de arbeiders en strijdt voor de rechten van de werdachte, maar is ook van mening dat er harder tegen de criminaliteit opgetreden moet worden. Dit is een breuk met het verleden waarin criminaliteitsbestrijding geen aandachtspunt was.

\section{RIGHT}

stelt een tougher criminal justice voor, maar wil eveneens bezuinigen. Rechts in Engeland en Wales staat symbool woor law and order. $^{713}$

terwijl de doelstellingen van de REGERING in de jaren " 80 waren:

\section{Law and Order en}

Economize in public servi:ces die eigenlijk elkaars. tegenpolen zijn. 
De doelstellingen van parlement en regering zijn dus de handhaving van recht en orde en het bezuinigingen op de landelijke uitgaven. Zowel in een links als een rechts parlement zien we ambivalente doelstellingen. Ook de regering wordt aldus geconfronteerd met tegengestelde verwachtingen. Door deze doelstellingen krijgt de politie te maken met tegenstrijdige beleidsdoeleinden. ${ }^{774}$ Van de ene kant moet er effectiever en efficiënter gewerkt worden, van de andere kant moet er bezuinigd worden bij de openbare diensten waar ook de politie onder valt. Dat betekent korten op het aantal manschappen en op de (technische) middelen. Efficiënter werken met minder mensen en hulpmiddelen zal voor de politieorganisatie een niet haalbaar doel blijken. Bovendien wordt een open en eerlijk beleid van de politie verwacht dat in conflict kan komen met effectief politieoptreden. Met andere woorden, de politie is in een moeilijke positie terechtgekomen. Van allerlei kanten wordt aan de politie getrokken. Ze moet beter functioneren met minder geld. Maar de politie staat ook veelvuldig onder druk van de media om zo effectief mogelijk op te treden.

\subsection{Hervorming van het strafrechtsysteem}

Zal het rapport van de Royal Commission on Criminal Justice een hervorming of een kruistocht tot gevolg hebben? Het zal enige jaren duren voordat we iets zinnigs kunnen zeggen over het effect van de Royal Commission op de politie en de strafprocedure. Wanneer het rapport eenmaal besproken is in het Britse parlement, zal een commissie benoemd worden die de aanbevegen. ${ }^{775}$ Een wetswijziging vraagt veel tijd en ook daar zal enige tijd overheen gaan. In het rapport en in de aanbevelingen is mijns inziens onvoldoende aandacht geschonken aan het gebrek van het afleggen van verantwoording door de politie. Wat men wel wil wijzigen is de rest van het strafproces.

Packer is van mening dat een herworming van het strafrechtsysteem onlosmakelijk werbonden is met een herworming wan het politieapparaat. Packer haalt in zijn boek, The Limits of the Criminal Sanction. Sir Robert Peel aan, die in de 19 de eeuw al inzag dat wijziging van het strafrechtsysteem slechts

774. Vgl. Hutton, 1995, p. 5: "The police, which in the past had been moving from a "force' to a community "service" (liaising with victims, the elderly and the mentally ill) has been told to concentrate wholly on "catching criminals' and maintaining public order'.

775. In 1993 zijn in de maanden na het uitkomen van het rapport zo nu en dan aspecten van het rapport in het parlement besproken. Bijwoorbeeld over de Criminal Cases Review Authority in 234, H.C. Deb., 6th Ser., written answers, kolom 651; 233, H.C. Deb., 6Th Ser., kolom 568 . 
effectief kon worden doorgevoerd als de politie in staat was het systeem goed te laten functioneren. Theorie en praktijk van hervorming van het strafrechtsysteem moeten in elkaars verlengde liggen. In veel gevallen zall dit betekenen dat bij wijziging van het systeem ook de bevoegdheden en rechten van het politieapparaat gewijzigd zullen moeten worden. ${ }^{776}$ Tevens begreep Peel dat de politie pas goed zou kunnen functioneren, als de wet de goedkeuring had van de burgers. Parlementslid Chris Mullin is tegenwoordig ook die mening toegedaan: "There is not the slightest hope of successfully overhauling our criminal justice system without a dramatic change in the culture of our police, particularly in the elite detective squads. If public confidence is to be restored there will have to be a thorough review of police recruitment, training and disciplinary procedure and the introduction of a genuinely independent complaints procedure." ${ }^{777}$ Mullin had daarom ook graag gezien dat de commissie in haar onderzoek de gevolgen van de miscarriages of justice-zaken voor het politieapparaat had betrokken. ${ }^{778}$

De commissie heeft in haar rapport veel hervormingen voorgesteld. In het licht van de theorie van Reisman is een hervorming, uitgedrukt in wetgeving, iets dat een verandering voorstaat in gedrag. In dit kader kan men zich afvragen in hoeverre de voorgestelde hervormingen daadwerkelijke hervormingen zullen worden. In dit verband kunnen de voorstellen van de commissie wellicht eerder opgevat worden als een crusade. Al worden er immers wetswijzigingen voorgesteld, voor het eigenlijke probleem, i.e. het woorkómen van miscarriages of justice, bieden zij geen echte oplossing. Men wekt slechts de indruk dat er iets gedaan wordt. Inderdaad zijn er bepaalde voorstellen gedaan die wat meer dan andere de aandacht in de media krijgen. Evenwel, veel van deze voorstellen gaan voort op het pad dat juist onderworpen was aan het kritisch oordeel van de commissie. Met andere woorden de voorstellen trachten niet zozeer misstanden tegen te gaan dan wel rechten van verdachten te beperken. ${ }^{779}$

\subsection{Afsluiting}

De wetswijzigingen die de laatste decennia in Engeland en Wales zijn doorgevoerd zijn, om in de termen van Reisman te spreken, geen echte hervormingen maar 'slechts' kruistochten geweest. Zoals al eerder gezegd, hoeft een kruistocht op zich zelf nog geen probleem te zijn. Het wordt echter wel problematisch als aan de basis van de doorgevoerde wetswijzigingen steeds

776. Vgl, Packer, 1968, p. 365-366.

777. Mullin, Evidence to the Royal Commission on Criminal Justice, November 1991, (ongepubliceerd), $\$ 25$.

778. Ibidem.

779. Zie cok Lensing. 1994, p. 591. 
een zelfde soort oorzaak ten grondslag ligt, in casu het feit dat de politie geen verantwoording hoeft af te leggen. ${ }^{780}$

Zouden de problemen opgellost kunnen worden als er een verantwoordingsplicht geschapen zou worden? Is een oplossing te vinden in een politie die meer, duidelijker en zichtbaarder gecontroleerd wordt? De ontwikkelingen van de laatste tijd bij de politie in Engeland en Wales wijzen wel in die richting. Er wordt gesteld dat de politie meer open en eerlijk naar de burgers toe moet optreden waardoor de burgers inzicht krijgen in de werkwijze van de politie. Dit komt de vertrouwensrelatie tussen politie en burgers ten goede waardoor het beginsel policing by consent werkelijkheid kan worden.

Aan de hand van de organisatie van de Nederlandse politie tracht ik in de volgende twee hoofdstukken een antwoord te vinden op de in de voorgaande alinea gestelde vragen. Met de behandeling van Nederlandse Politiewet wil ik nagaan of een politie met een wettelijke verantwoordingsplicht te prefereren valt boven een politie, die formeel gezien onafhankelijk is. Zorgen de controlerende instanties ervoor dat misbruik van bevoegdheden niet of minder voor kan komen? Kan een politie, die verantwoording moet afleggen, beter gecontroleerd worden? Ook deze vragen zullen in de volgende hoofdstukken aan de orde komen. Allereerst behandel ik de recente politiereorganisatie die enkele wijzigingen gebracht heeft in de gezagsverhoudingen.

Zoals in Hoofdstuk 2 aangegeven, is het niet mijn bedoeling om de Nederlandse politie en schandalen te vergelijken met de politie en schandalen in Engeland en Wales. De Nederlandse situatie wordt slechts als illustratie behandeld om aan te tonen dat bij een niet of minder onafhankelijke politieorganisatie ook fouten worden gemaakt. ${ }^{781}$ Niettemin wordt zo nu en dan wel kort verwezen naar de situatie in Engeland en Wales, met als doel om de situatie in Engeland en Wales te verduidelijken aan de hand van de $\mathrm{Ne}$ derlandse situatie of andersom.

780. Met uitzondering van verantwoording alan de wet.

781. In Hoofdsuk 2 noemde ik het een kort uitstapje. Veeleer kan er sprake zijn van een thuiswedstrijd. 


\title{
11 De reorganisatie van de politie in Nederland
}

\begin{abstract}
'Het beheer van de politie is te belangrijk om aan de politie zelf te worden overgelaten. Het wordt daw ook hoog tijd dal politiechefs die hun plaats niet kennen met de wet in de hand die plaats wordl gewezen. Hoe hoog een ambtenaar wan politie mag stijgen, hij is en blijft de dienaar en diender van het benoegde gezag. "782:
\end{abstract}

\subsection{Inleiding}

In 1994 is de Nederllandse Politiewet 1993 in werking getreden. De Politiewet 1993 herstructureerde het politieapparaat. In plaats van 148 gemeentekorpsen en de Rijkspolitie werden er 25 regiokorpsen en één landelijke politiedienst (het Korps landelijke politiediensten (KLPD)) gecreëerd. Deze schaalvergroting en de - volgens de regering - daarmee gepaard gaande verbetering van de bedrijfswoering werden door de regering noodzakelijk geacht om de kosten van het politiebestel beheersbaar te houden. ${ }^{783}$

Reeds in de jaren zeventig bestonden er ideeën om het bestuur te reorganiseren waarbij de provincie in een sterkere positie zou worden geplaatst. ${ }^{784}$ Het aantal provimcies zou bij deze voorstellen uitgebreid worden van 11 naar 24 omdat men de bestaande $\$ 1$ provincies te groot van omvang achtte voor de nieuwe taken. ${ }^{785}$ Ook de politie zou daarbij gereorganiseerd worden tot een provinciale politie. ${ }^{785}$ Deze voorstellen voor een nieuw type provincie zijn weliswaar in de jaren daarna ingetrokken maar het voornemen on het bestuur en de politie te reorganiseren is nooit geheel verdwenen. ${ }^{787}$ Dit heeft uiteindelijk in 1993 geleid tot een nieuwe Politiewet, waarin sporen van de oorspronkelijke ideeën zijn terug te vinden. ${ }^{788}$ In de Politiewet 1993 wordt een regio geïntroduceerd. De regio is een relatief nieuw begrip in het Nederlands staatsrechtbestel. ${ }^{789}$ Volgens de memorie van toelichting gaat het om een rechtsfiguur 'met uitputtend in de wet omschreven be-

782. Fasseur, 1994, p. 397

783. TK, 1991-1992, 22562, MvT, p. 4.

784. Ontwerp van Wet reorganisatie binnenlands bestuur en ontwerp van Wet tot wijziging van de provinciale indeling. Bijl Hand. TK, 1976-1977, 14322, 14323.

785. TK, 1991-1992, 22562, MvT, p. 3. Zie ook Versteden/Renes, 1994, p. 16; Ellzinga, Van Rest en De Valk, 1995, p. 222.

786. Ontwerp van Wet tot vaststelling van een nieuwe Politiewet. Bijl. Hand. $T K$. $1980-1981,16812$.

787. Versteden/Renes, 1994, p. 15-16.

788. De reorganisatie vormde een onderdeel van het regeerakkoord van het kabinet Lubbers IIII.

789. Vgl bijwoorbeeld Rijnmond. 
stuursbevoegdheden., 790 In het algemeen wordt er vanuit gegaan dat de reorganisatie van de politie een bestuurskundig experiment is. Mocht blijken dat de reorganisatie over een aantal jaar een succes zal zijn, dan zal een reorganisatie van het bestuur volgen. ${ }^{791}$ Een eerste aanzel tot een nieuw regionaal bestuur lijkt vervat te zijn in de Kaderwet Bestuur in verandering ${ }^{792}$. Deze wet wil de totstandkoming van een regionaal bestuur bevorderen in de daartoe aangewezen gebieden.

In 1987 werd door Rosenthal opgemerkt dat de politie-organisatie in Nederland pas een grondige verandering zou ondergaan na het aan het licht komen van een crisis. ${ }^{793}$ Deze constatering van Rosenthal past in de theorie van Sherman. Een crisis kan voldoende ruimte scheppen voor hervorming. Rosenthal heeft achteraf gezien geen gelijk gekregen. Er is in de laatste twee decennia veel gediscussieerd over het politiebestel en het politiebestel is inmiddels gereorganiseerd, maar niet naar aanleiding van een crisis.

Terwijl in Engeland en Wales na 1964 de Police Act op sommige punten en op verschillende momenten behoorlijk gewijzigd is na het bekend worden van schandalen, zien we in Nederland in de periode tussen 1957 en $1993^{794}$ geen enkele opvallende wijziging. ${ }^{795} \mathrm{Nu}$ onze politieorganisatie in 1994 een drastische wijziging ondergaan heeft zonder een schandaal of een crisis - zoals in Engeland en Wales -, resteert alleen de vraag of de redenen om het politieapparaat te reorganiseren een voldoende basis geven en toereikend zijn om de gewenste doelen te bereiken. Heeft de reorganisatie geleid tot een duidelijke en doeltreffende controlestructurur met betrekking tot de politie in ons land? Deze punten worden in dit hoofdstuk besproken.

790. $T K, 1991-1992,22562, \mathrm{MvT}, \mathrm{p} .40-41$.

791. Vgl. ook TK, 1991-1992, 22562. MvT, p. 3; Van Reenen, 1993, p. 18-19; Doctors van Leeuwen, 1992, p. 388.

792. Wet van 21 april 1994, Stb. 396.

793. Rosentual, in Koppenjan, Ringeling en Te Velde, 1987, p. 241.

794. Politiewet 1957, Wet wan 4 juli 1957, Stb. 244.

795. Wel zien we al vanaf 1969 pogingen om de Politiewet te wijzigen. "Het blatwwe boekje' (1969), Nota Herziening Politiewet (1972) Kamerstuk 10124, Worontwerp Politiewet (1980), Kamerstuk 14322, Wetsontwerp (1981) Kamerstuk 16812, Nora De Toekomst Van Het Politiebestel (1985) Kamerstuk 18874, Wetswoorstel (1986) Kamerstulk 19535. Kritiek bestond over het grote aantal politiekorpsen en over tekortkomingen op het terrein van organisatie en efficiëntie. In de Tweede Kamer wilde men het dualisme gemeente- en Rijkspolitie opheffen. Perrick, 1982, p. $48-49$. 
Allereerst ga ik kort in op de Politiewet 1993. Daarna behandel ik de redemen van de reorganisatie en de doelen achter de Politiewet 1993. Vervolgens wordt nagegaan wat de gevolgen kunnen zijn van de reorganisatie voor effectiviteit ${ }^{796}$ en efficiëntie ${ }^{797}$ van het politieoptreden. In het volgende hoofdstuk bekijk ik onder andere of door de Politiewet 1993 de mogelijkheid is geschapen, dat de Nederlandse politie onafhankelijker wordt.

\subsection{De Politiewet 1993}

\subsection{De reikwijdte van de wet}

De Politiewet 1993 is op 1 april 1994 in werking getreden. ${ }^{798}$ Door deze wet zijn de 148 gemeentekorpsen en het korps Rijkspolitie opgegaan in 25 regionale politiekorpsen. ${ }^{799}$ Daarnaast is een korps gevormd dat belast is met landelijke politietaken (KLPD). Hierbij moet gedacht worden aan de Algemene Verkeersdienst, de Rijkspolitie te water, de Veiligheidsdienst van het Koninklijk Huis en de Centrale Recherche Informatiedienst. ${ }^{800}$ De Rijksrecherche, die o.a. onderzoek verricht naar gedragingen van politieambtenaren van strafrechtelijke of disciplinaire aard, is eveneens opgenomen in de Politiewet 1993. ${ }^{\circ 0}$ De leden van de Rijksrecherche worden bijzondere ambtenaren van politie genoemd. In artikel 6 Politiewet 1993 zijn de politietaken van de Koninklijke marechaussee opgenomen. ${ }^{802}$ De Koninklijke marechaussee is, aldus Elzinga, Van Rest en De Valk, echter nooit als onderdeel van de politie aangemerkt. Zij vormt daarentegen een onderdeel van de krijgsmacht. Vanwege de rechtszekerheid en de rechtsbescherming van de burger werd het door de regering wenselijk geacht de politietaken van de Koninklijke marechaussee in de politiewet te omschrijven en de

796. De mate waarin de beoggde doelen bereikt worden. Bruinsma, 1994, p. 372; Van Reenen, 1994, p. 364-365.

797. De mate waarin met de gegeven middelen zoveel mogelijk zaken afgewerkt worden. Bruinsma, 1994, p. 372.

798. Wet van 9 december 1993, Stb. 724. Een deel van de wet is op 18 januari 1994 in werking getreden. De rest trad op 1 april 1994 in werking. Staatsblad 1994 , nir. 27.

799. Portegies-Damave, 1994, p. 512.

800. Portegies-Damave, 1994, p. 512.

801. In artikel 3 lid 2 jo art. 43.

802. De taken van de marechaussee zijn: het bewaken van de veiligheid van de leden wan het Koninklijk Huis, de politietaak voor de strijdkrachten en op de luchthavens, de grensbewaking, de uitwoering van de Vreemdelingen wet de bijstandsverlening aan de politie en de beveiliging van De Nederlandsche Bank N.V. Deze taakomschrijving stond trouwens al sinds 1988 in de vorige Politiewet. Zie verder over de Koninklijke marechaussee: Fijnaut, 1994, p. 998-1009. 
Koninklijke marechaussee voor die taken gelijk te stellen aan de civiele politie. ${ }^{803}$

\subsubsection{Taak, samenstelling en bevoegdheden}

Politie-ambtenaren zijn volgens de Politiewet 1993 onder te verdelen in a) ambtenaren, aangesteld voor de uitwoering van de politietaak, b) ambtenaren, aangesteld voor de uitwoering van technische, administratieve en andere taken ten dienste van de politie, c) vrijwillige ambtenaren, aangesteld voor de uitvoering van een politietaak (art. 3 en 5 Politiewet 1993) en d) bijzondere ambtenaren (Rijksrecherche: art. 3 lid 2 en 43 Politiewet 1993).

De politie heeft tot taak in ondergeschiktheid aan het bevoegde gezag en in overeenstemming met de geldende rechtsregels te zorgen voor de daadwerkelijke handhaving van de rechtsorde en het verlenen van hulp aan hen die deze behoeven. De omschrijving van de taak heeft, in vergelijking met de oude wet, een opvallende plaats vooraan in de wet gekregen: art. 2 Politiewet 1993.

Vanwege de samenhang tussen taak en bevoegdheden heeft de regering het logisch geoordeeld de bevoegdheden in de wet direct na de taak van de politie te plaatsen. ${ }^{804}$ Elzinga, Van Rest en De Valk verdelen de politiebevoegdheden in drie soorten: bevoegdheden die samenhangen met de strafrechtelijke ordehandhaving, bevoegdheden die de openbare ordehandhavende taak betreffen en bevoegdheden die expliciet bij of krachtens de Politiewet 1993 zijn geregeld, zoals de aanwending van geweld en de veiligheidsfouillering. ${ }^{805}$

\subsubsection{Gezag en toezicht over de politie}

Het gezag over de politie in een gemeente ter zake van de handhaving van de openbare orde berust bij de burgemeester. Het gezag over de politie bij de strafrechtelijke handhaving van de rechtsorde en bij het verrichten van taken ten dienste van justitie berust bij de officier van justitie. In artikel 1 worden de laatstbedoelde taken als volgt omschreven:

- de uitvoering van de wettelijke voorschriften waarmee de minister van Justitie is belast;

- de handhaving van de lex Mulder en

803. TK, 1985-1986, 19535, MvT, p. 3, MvA, p. 17-18.

804. TK, $191991-1992,22562$, MvT, p. 34-35.

805. Elzinga, Van Rest en De Valk, 1995, p. 72-73. 
- de betekening van gerechtelijke mededelingen in strafzaken, het vervoer van gedetineerden en de ordedienst bij de gerechten. ${ }^{\$ 06}$

Burgemeester en officier van justitie kunnen de politieambtenaren aanwijzigingen geven voor de vervulling van hun taken. In het driehoeksoverleg geformaliseerd in art. 14 -, waarbij naast burgemeester, officier van justitie en de (territoriale) onderdeelschef ${ }^{807}$ ook in voorkomende gevallen de korpschef betrokken is, wordt de takuitwoering van de politie besproken.

\subsubsection{Regio}

Bij de totstandkoming van de Politiewet 1993 is gekozen voor een indeling in 25 regio's. De grenzen van de arrondissementen zijn niet consequent gevolgd. Nu bestaat een zestal arrondissementen uit twee regio's. Omdat het Openbaar Ministerie betrokken wordt bij het beheer van de regionale politie, lijkt de keuze voor de grenzen van de arrondissementen niet geheel onlogisch. 'Arrondissements- of provincie-overschrijdende politieregio's passen (...) niet in het nieuwe politiebestel, ..." ${ }^{809}$ Met het oog op een eventuele verdere reorganisatie naar een provinciale politie is dit van belang. Volgens Elzinga, Van Rest en De Valk is het echter de vraag of uiteindelijk de grenzen van de politieregio's wel zullen samenvallen met die van een nieuw regionaal bestuur. ${ }^{810}$

\subsubsection{Regionaal college}

Aan de politieregio is rechtspersoonlijkheid toegekend (art. 21 lid 4 Politiewet 1993). De politieregio wordt bestuurd door het regionaal college. Het regionaal college bestaat uit alle burgemeesters binnen de regio en de hoofdofficier van justitie. Voorzitter van het regionaal college is de korpsbeheerder. ${ }^{811} \mathrm{Hij}$ heeft de bevoegdheid om de regio in en buiten rechte te vertegenwoordigen. ${ }^{812}$ In de bijlage bij de Politiewet 1993 staat vermeld welke gemeente de korpsbeheerder levert. In de meeste gevallen zal de korpsbeheerider de burgemeester van de provinciehoofdplaats of van de grootste

806. Zie artikel 1 Politicwet 1993 . Fasseur, 1994, p. 392.

807. TK, 1991-1992, 22562, MvT, p. 38.

808. Te weten "s-Hertogenbosch, 's-Gravenhage, Arnhem, Amsterdam, Zwolle en Haarlem.

809. TK, 1991-1992, 22562, MvT, p. 5.

810. 1995, P. 222.

811. De korpsbeheender dient over het beheer verantwoording af te leggen tegenover het regionaal college. Artikel 30 lid 1 Politiewet 1993.

812. Art. 22 lid 3 Politiewet 1993. 
gemeente in de regio zijn. ${ }^{813}$ De korpschef neemt, aldus art. 22 lid 2 Politiewet 1993, deel aan de vergaderingen van het regionaal college. De korpschef mag echter niet stemmen in de vergadering.

Het regionaal college stelt jaarlijks de organisatie, formatie, begroting, jaarrekening en het beleidsplan voor het regionaal politiekorps vast. De besluitworming van deze onderwerpen wordt woorbereid door korpsbeheerder en hoofdofficier van justitie. De korpsbeheerder is voor de uitvoering van het beleidsplan eind verantwoordelijk.

\subsubsection{Geen eigen politie}

Bij de regionale korpsbeheerder berust voortaan het beheer van het regionale politiekorps. ${ }^{815}$ Door de Politiewet 1993 heeft, aldus Van Reenen, de gemeente 'geen eigen politie meer'. 816 De burgemeesters van de overige gemeenten in de regio worden, volgens de memorie van toelichting, nauw betrokken bij besluitvorming inzake het beheer. Zij vormen samen met de hoofdofficier van justitie immers het regionaal college. ${ }^{817}$ Desalniettemin zou hun invloed op de politie in hun eigen gemeente behoorlijk kunnen afnemen. Ingevolge artikel 36 kunnen bevoegdheden met betrekking tot een territoriaal onderdeel overgedragen worden aan de burgemeester(s) van de betrokken gemeente(n). ${ }^{818}$ In het beleidsplan moet worden bepaald welke bevoegdheden het betreft. In de memorie van toelichting wordt de reden hiervoor gegeven: '.. dit artikel komt aldus tegemoet aan de wens om de burgemeesters een duidelijke invloed te verschaffen op het beheer van het in de gemeente aanwezige onderdeel van het regionaal korps. Deze invloed op het beheer dient zodanig te zijn, dat de burgemeesters hun verantwoordelijkheid voor de handhaving van de openbare orde en de hulpverlening kunnen dragen." ${ }^{819}$ Aldus wordt door middel van delegatie tegemoet gekomen aan de wens dat burgemeesters van de lokale onderdelen betrokken blijven bij een aantal beheersmatige beslissingen. Door delegatie wordt het

813. TK, 1991-1992, 22562, MvT, p. 8-9, 40. Uitzonderingen zijn Middelburg in plaats van Vlissingen en Assen in plaats van Emmen. Elzinga, Van Rest en De Valk, 1995, p. 232.

814. Artikel 31 Politiewet 1993.

815. De burgemeester blijf wel in zijn gemeente het gezag behouden indien de politie optreedt ter handhaving van de openbare orde en ter uitwoering van de hulpverleningstaak. Art. 12. Politiewet 1993.

816. Van Reenen, 1993, p. 14

817. Art. 22 lid 2 Politiewet 1993. TK, 1991-1992, 22562, Mvrt, p. 9.

818. In lid 2 wordt aangegeven welke beheersbevoegdheden in ieder geval bij de lokale burgemeester berusten. Elzinga, Van Rest en De Valk, 1995, p. 263.

819. TK, 1991-1992, 22562, MvT, p. 11-12. 
mogelijk voor de gemeenteraden om hun burgemeester ter verantwoording te roepen.

\subsubsection{Korpsbeheerder}

Bij de korpsbeheerder berust dus het beheer van het regionale politiekorps. ${ }^{820}$ Het beheer omvat zaken als administratieve en interne organisatie, materieel, middelen, personeelsbeleid, financièn en informatie. ${ }^{821} \mathrm{Bij}$ deze taak wordt hij bijgestaan door de korpschef. Belangrijke beslissingen over het beheer worden genomen door de korpsbeheerder in overeenstemming met de hoofdofficier van justitie. ${ }^{822} \mathrm{Bij}$ die beslissingen moet gedacht worden aan het ontwerpen van het beleidsplan, van de formatie, van de begroting en van de jaarrekening. ${ }^{823}$

\subsubsection{Gemeenteraad}

De gemeenteraden van de verschillende gemeenten worden geïnformeerd over de besluitvorming van korpsbeheerder en Officier van Justitie. ${ }^{824}$ Volgens de memorie van toelichting garandeert deze informatieplicht de democratische controle over de besluitworming. ${ }^{825}$ Deze democratische controle is aldus Portegies-Damave, echter indirect, want de burgemeester kan in de gemeente alleen aangesproken worden op de manier waarop hij invulling geeft aan zijn lidmaatschap van het regionaal college en over de manier waarop hij witvoering geeft aan de hem in het beleidsplan toegekende beheersbevoegdheden. ${ }^{826}$ De gemeenteraad en de burgemeester hebben wel de mogelijkheid administratief beroep in te stellen bij de commissaris van de Koningin tegen de besluitworming van het regionaal college wanneer deze besluitvorming in strijd is met het belang van een goede vervulling van de politietaak in de gemeente. ${ }^{827}$ Het beroepsschrift wordt ingediend door tus-

820. Het verschill tussen bestuur en beheer wordt door de regering als volgt uitgelegd:

- Bestuur impliceert dat verantwoording kan worden gevrangd woor het gevoerde beheer en dat de belangrijkste stukken met betrekking tot het beheer van het regionale politiekorps worden vastgesteld door het regionaal college. Tot het beheer behoren alle beslissingen die genomen moeten worden om het regionale politiekorps richtig te doen functioneren.' $T K, 1992-1993,22562$, nr. 10, p. 11 .

821. Elzinga, Van Rest en De Valk, 1995, p. 239-240.

822. Art. 28 lid 1 Politiewet 1993.

823. TK, 1991-1992, 22562, MvT, p. 9.

824. Artikel 28 Politiewet 1993.

825. TK, 1991-1992, 22562, MvT, p. 9.

826. Portegies-Damave, 1994, p. 518; TK, 1991-1992, 22562, MvT, p. 12.

827. Art. 34 lid 3 politiewet 1993. 
senkomst van de korpsbeheerder. De commissaris van de Koningin beslist op het beroepsschrift in overeenstemming met de procureur-generaal. Wanneer er geen overeenstemming bereikt wordt, treden de minister van Binnenlandse Zaken en de minister van Justitie in de plaats van de commissaris van de Koningin en de procureur-generaal. Elzinga, Van Rest en De Valk $^{228}$ zijn wan mening dat een gemeenteraad dit instrument slechts in uitzonderingsgevallen zal kunnen gebruiken en dat de kans dat het bezwaar gehonoreerd wordt door commissaris der Koningin, procureur-generaal en ministers zeer klein zal zijn.

\subsubsection{Korpschef}

De 148 hoofdcommissarissen zijin vervangen door 26 korpschefs. De korpschefs hebben in de Politiewet 1993 geen zelfstandige taak toebedeeld gekregen. Zij hebben geen eindverantwoordelijkheid over begroting of beleidsplan en kunnen in tegenstelling tot hun collega's in Engeland en Wales dus niet een eigen beleid uitstippelen. De korpschefs zijn hiermee niet tevreden. ${ }^{829}$ In de wet is echter op deze manier een zekerheid ingebouwd dat de politie niet zelf beleidsbesluiten kan ontwikkelen en uitwoeren. Dit kan het ontstaan van een onafhankelijke politie voorkomen. ${ }^{810}$

Al zijn door de Politiewet 1993 de korpschefs in een positie gebracht dat ze meer gebonden lijken, toch is er in de wet ruimte gelaten voor het overdragen van beheersbevoegdheden aan de korpschef. Volgens art. 24 Politiewet 1993 staat de korpschef de korpsbeheerder bij. Door middel van mandaat kan de korpsbeheerder beheersbevoegdheden overdragen aan de korpschefs. ${ }^{831}$ De korpschef kan deze bevoegdheden submandateren aan de plaatselijke politiechefs. Bij deze constructie blijft de politieke verantwoordelijkheid berusten bij de korpsbeheerder. De korpschef is formeel ondergeschikt aan de korpsbeheerder.

828. 1995, p. 252.

829. Zie bijwoorbeeld Fasseur, 1994, p. 394, waar hij verwijst naar de voorzitter van de Raad van Hoofdcommissarissen die "nimmer zal accepteren, dat de korpschefs waruit een ondergeschikte positie met korpsbeheerders en hoofdofficieren zouden moeten samenwerken...".

830. Zie ook Fasseur, 1994, p. 394.

831. Elzinga, Van Rest en De Valk, 1995, p. 242, 259; zie ook Naeyé, 1995, p. 46. 


\subsubsection{Hoofdofficier van Justitie}

Vergeleken met de regeling in de oude Politiewet heeft de hoofdofficier van justitie in de Politiewet 1993 meer te zeggen gekregen over het beheer van de politie ${ }^{832}$ Aan de hoofdofficier van justitie is een instemmingsrecht gegeven. ${ }^{833}$ Dit instemmingsrecht geldt woor het ontwerp en de definitieve vaststelling van de begroting, de formatie, de jaarrekening, de organisatie en het beleidsplan. Door dit recht heeft hij een middel in handen gekregen om er voor te zorgen dat de justitiële taken van de politie in het beleidsplan niet onderbelicht raken. Bovendien kan hij zo bevorderen dat het beleidsplan op dit punt in overeenstemming is met het beleidsplan van andere regio's, hetgeen noodzakelijk is voor een effectieve misdaadbestrijding op grotere schaal. Wanneer de hoofdofficier van justitie bezwaar heeft tegen de ontwerp-stukken, kan hij dit voorleggen aan de procureur-generaal. Deze laatste beslist in overeenstemming met de commissaris van de Koningin (vgl. art. 29 Politiewet 1993). Tegen de vaststelling van de definitieve stukken kan hij op dezelfde wijze als de korpsbeheerder administratief beroep instellen bij de commissaris van de Koningin. De commissaris van de Koningin beslist over het beroep in overeenstemming met de procureur-generaal (vgl. art. 32 Politiewet 1993).

\subsubsection{De driehoek}

De wet kent twee soorten driehoeksoverleg. In art. 14 is het lokale driehoeksoverleg tussen burgemeester, officier van justitie en politiechef beschreven. In art. 27 is bepaald dat korpsbeheerder, hoofdofficier van justitie en korpschef regelmatig overleggen over het beheer van het regionale politiekorps. Elzinga, Van Rest en De Valk stellen dat binnen het lokale driehoeksoverleg er formeel geen gelijkwaardigheid is tussen partijen. Burgemeester en officier van justitie hebben immers het gezag over de politie. De politiechef is derhalve ondergeschikt aan de andere twee partijen. Bij het regionale driehoeksoverleg is er weliswaar een hiërarchische verhouding tussen korpsbeheerder en kurpschef, maar niet tussen hoofdofficier van justitie en korpschef, aldus Elzinga, Van Rest en De Valk. In beide overlegstructuren wordt er echter naar gestreefd het overleg zoveel mogelijk in gelijkwaardigheid te laten plaatsvinden. ${ }^{834}$

832. Elzinga, Wan Rest en De Valk, 1995, p. 243.

833. Artikel 28 en 29 Politiewet 1993.

834. Elzinga, Van Rest en De Valk, 1995, p. 203, 247. 


\subsubsection{Het Korps landelijke politiediensten}

Naast de 25 regionale korpsen is er een Korps landelijke politiediensten (KLPD) ${ }^{835}$ Dit KLPD bevat diensten die taken verrichten die niet of moeilijk op thet regionale niveau kunnen worden uitgeoefend. ${ }^{836}$ De taken van dit korps zijn (a) de uitvoering van landelijke en specialistische politietaken, (b) het verzorgen van de landelijke inlichtingenfunctie en andere ondersteunende faciliteiten, (c) het bewaken van de veiligheid van de leden van het Koninklijk Huis en (d) het verzorgen van de facilitaire diensten inzake bewapening, kleding en uitrusting van de politie. ${ }^{837}$ Het beheer over het KLPD berust bij de minister van Justitie die daarbij wordt bijgestaan door de korpschef (art. 38 lid 3 Politiewet 1993). In het oorspronkelijke wetsvoorstel was opgenomen dat de minister eveneens de jaarstukken zou vaststellen van het korps. Bij de behandeling van de Politiewet 1993 in de Tweede Kamer werd er opgemerkt dat de minister van Justitie dan te veel zeggenschap over het KLPD zou verkrijgen. Om die reden is het voorstel gewijzigd en bepaalt art. 39 lid 2 jo art. 41 lid 1 Politiewet 1993 dat de Raad voor het KLPD de jaarstukken vaststelt die vervolgens goedgekeurd worden door de minister. De Raad voor het KLPD is samengesteld uit een voorzitter en ten hoogste acht leden, waarvan enkele leden uit kringen van binnenlands bestuur en enkele leden van het Openbaar Ministerie (art. 40 lid 1 Politiewet 1993).

\subsubsection{Beheersbevoegdheden en aanwijzingsbevoegdheden op rijksniveau}

Op rijksniveau fungeert de minister van Binnenlandse zaken als beheerder op afstand. De minister van Binnenlandse Zaken verstrekt jaarlijks bijdragen voor de financiering van de regionale korpsen. Bij algemene maatregel van bestuur worden door de minister van Binnenlandse Zaken, in overeenstemming met de ministers van Justitie en Financiën nadere regels gesteld inzake de uitwoering van de bijdragen, die vervat zijn in een "brede doeluitkering'. ${ }^{838}$ Er zijn geen bestedingsvoorwaarden verbonden aan de doeluitkering en de politieregio's kunnen binnen hun budget vrijelijk invulling geven aan de componenten middelen, personeel en investeringen. ${ }^{839}$ De minister van Binnenlandse Zaken, in overeenstemming met de minister van Justitie houdt echter toezicht op het financiële beheer van de regionale politiekorpsen (art. 45 lid 4 Politiewet 1993).

835. Zie hierover Portegies-Damave, 1994, p. 517-518; Boek, 1995, p. 356-359; Elzunga, Van Rest en De Valk, 1995, p. 270-295.

836. Boek, 1995 , p. 357 .

837. Zie art. 38 Politiewet 1993; vgl. Boek, 1995, p. 358.

838. TK, 1991-1992, 22562, MvT, p. 16.

839. TK, 1992-1993, 22562, MvA, nr. 10, p. 29. 
'Beheer op afstand' laat zien dat de regering de politieregio's een zo groot mogelijke zelfstandigheid heeft gegeven. Echter, '(d)e aan de politieregio toe te kennen vrijheid mag een effectieve controle, zowel preventief als zo nodig repressief, op een goed financieel beheer van de ter beschikking gestelde overheidsmiddelen niet uitsluiten. ${ }^{840}$ Interventies in het beheer van de regionale politiekorpsen zijn beperkt tot die gevallen 'waarin een ontbreken van een bepaalde mate van sturing op centraal niveau in het beheer van de regionale politiekorpsen zou leiden tot verspilling of verkeerde besteding van schaarse overheidsmiddelen. ${ }^{841}$

Aan de minister van Justitie is in art. 53 lid 1 ten aanzien van personeel en middelen een bevoegdheid toegekend aanwijzingen te geven aan de korpsbeheerder teneinde 'de verantwoordelijkheid voor de rechtshandhaving beter tot haar recht te laten komen". ${ }^{842}$ Uit de memorie van toelichting wordt duidelijk dat deze bevoegdheid slechts in uitzonderingsgevallen gebruikt zai worden: 'Men kan denken aan buitengewone ernstige inbreuken op de rechtsorde die een onmiddellijke voorziening vereisen, zoals een grootschalige gijzelingsactie, het optreden in ernstige gevallen van georganiseerde misdaad, waarwoor onverwijld politiepersoneel moet worden vrijgemaakt, ... Het is uitdrukkelijk niet de bedoeling dat de Minister van Justitie op deze wijze structureel zal kunnen ingrijpen in het beheer en de organisatie van de regionale politiekorpsen. ${ }^{843}$

Een vergelijkbare aanwijzingsbevoegdheid heeft de minister van Binnenlandse Zaken gekregen ten aanzien van het beheer (art. 53 lid 2). Deze bevoegdheid kan gebruikt worden in het geval dat 'enige beslissing met betrekking tot het beheer in de regio effectief dreigt te worden die de eenheid van de Nederlandse politie in gevaar brengt, waardoor de onderlinge uitwisselbaarheid van het Nederlandse politiepersoneel wordt geschaad dan wel een beslissing van kracht dreigt te worden die onvoldoende uitvoering geeft aan het ten opzichte van speciale groepen uit de bevolking voorgestane overheidsbeleid. ${ }^{844}$

Art. 16 Politiewet 1993 geeft de commissaris der Koningin en de minister van Binnenlandse Zaken de bevoegdheid aan de burgemeesters aanwijzingen te geven met betrekking tot het te voeren beleid bij (dreigende) bovenlokale ordeverstoringen of bij ordeverstoringen waarbij bijvoorbeeld de veiligheid van de Staat in het geding is.

840. TK, 1992-1993, 22562, MvA, nr. 10, p. 30.

841. TK, 1992-1993, 22565, MvA, nr 10, p. 28.

842. TK, 1991-1992, 22562, MvT, p. 18.

843. TK, 1991-1992, 22562, MwT, p. 18.

844. TK, 1992-1993, 22562, MvA, nr 10, p. 32. 


\subsubsection{De klachtenregeling}

In de Politiewet 1993 wordt aan het regionaal college opgedragen om op voorstel van de korpsbeheerder regels vast te stellen over de behandeling, het onderzoek en de afdoening van klachten over het optreden van politieambtenaren. ${ }^{845}$ Een klacht over het politieoptreden wordt ingediend bij de burgemeester, die van elke klacht een afschrift zendt aan de officier van justitie. ${ }^{246}$ De burgemeester is ook degene die een onderzoek instelt naar de klacht, of indien de betreffende ambtenaar waarover geklaagd wordt bij een ander regiokorps in dienst is, ervoor zorgt dat de klacht bij het juiste regiokorps ingediend wordt.

De klachtenregeling in de Politiewet 1993 is slechts een raamregeling. De nadere uitwerking van de klachtenprocedure is overgelaten aan de regionale colleges. Deze mogen grotendeels zelf beslissen hoe de procedure eruit gaat zien. Overleg tussen de regionale colleges over vorm en verloop van de procedure is geen wettelijk vereiste. Dit heeft ertoe geleid dat de klachtenprocedure per regio verschilt ${ }^{847}$ Het feitelijk onderzoek naar de klacht zal in de meeste gevallen door de politie zelf uitgevoerd worden. Dit zou ertoe kunnen leiden dat er burgers zijn die zullen afzien van het indienen van een klacht omdat zij geen vertrouwen zullen hebben in de objectiviteit en onpartijdigheid van het onderzoek. ${ }^{848}$

Ook zonder de Politiewet 1993 kan er echter geklaagd worden over politieoptreden. De Nationale Ombudsman is bevoegd van klachten over de politie kennis te nemen. Een redelijk aantal klachten dat ingediend wordt bij de Ombudsman betreft het optreden van de politie. 'Op grond daarvan kan worden gesteld dat de nationale ombudsman een belangrijke functie vervult waar het gaat om het normeren van het politieoptreden in ons land. Gezien dit feit hoeft het geen verwondering te wekken dat de ombudsman weinig heil ziet in het in het leven roepen van klachtencommissies die zich op een vergelijkbare wijze bezig gaan houden met de beoordeling van klachten over politieoptreden. ${ }^{849}$ Inderdaad is er dan sprake van het samenlopen van

845. Voor het KLPD worden die regels vastgesteld door de Raad voor het KLPD op voorstel van de minister van Justitie. Art. 62 lid 1 Politiewet 1993. Voor de marechaussee en andere onderdelen van de krijgsmacht tenslotte worden regels vastgesteld door de minister van Defensie. Art. 63 lid 1 Politiewret 1993.

846. Kllachten over optreden van politieambtenaren van thet KLPD en van militairen van de marechaussee kunnen ook worden ingediend bij de minister van Justitie resp. de minister van Defensie.

847. Zie Elringa, Van Rest en De Valk, 1994, p. 357-373.

848. Vgl. Elzinga, Van Rest en De Valk, 1994, p. 339.

849. Elzinga. Van Rest en De Valk, 1994, p. 327. 
regelingen en kumnen de vragen worden gesteld of een aparte procedure nog wel nodig is en of twee verschillende regelingen de zaak er duidelijker op maken. ${ }^{850}$ Elzinga, Van Rest en De Valk merken in hun boek op dat de rol van de nationale ombudsman beperkt had kunnen worden tot het toetsen (een soort hoger beroep) van de afhandeling wan de klacht volgens de klachtenregeling in de Politiewet $1993{ }^{851}$

\subsubsection{Afronding: controle in de Nederlandse Politiewet}

In de Politiewet 1993 komen gezag en beheer uitgebreid aan de orde. De wet biedt aldus waarborgen tegen verzelfstandiging van de politie.

Voor de handhaving van de openbare orde berust het gezag over de politie bij de burgemeester en voor de strafrechtelijke handhaving van de nechtsorde en woor het verrichten van de justitiële taken berust het gezag bij de officier van justitie. Officier van justitie en burgemeester kunnen de politie aanwijzingen geven en in het driehoeksoverleg wordt de takuitwoering door burgemeester, officier van justitie, onderdeelschef en soms de korpschef besproken. De minister van Binnenlandse Zaken of de commissaris van de Koningin kan aanwijzingen geven ten aanzien van het beleid bij (dreigende) bovenlokale ordeverstoringen of bij ordeverstoringen waarbij de veiligheid van de Staat in het geding is.

Het beheer over de politie berust bij de korpsbeheerder. Bij deze taak wordt hij bijgestaan door de korpschef. De korpsbeheerder is voorzitter van het regionaal college. Het regionaal college stelt de organisatie, formatie, begroting, jaarrekening en het beleidsplan voor het regionaal korps vast. De besluitvorming hiervan wordt voorbereid door de korpsbeheerder en hoofdofficier van justitie.

Uit de regeling blijkt dat de korpschef (de vroegere hoofdcommissaris) ondergeschikt is aan de korpsbeheerder en formeel geen zelfstandige bewoegdheid heeft om (beleids-) beslissingen te nemen. Dit overigens in tegenstelling tot hetgeen chief constables in Engeland en Wales kunnen. De wetgever heeft echter de korpsbeheerder de mogelijkheid gegeven beheersbevoegdheden te mandateren aan de korpschefs die op hun beurt die bevoegdheden weer kunnen submandateren aan de lokale politiechefs. Hierdoor kunnen korpschefs en lokale politiechefs toch vrij zelfstandig optreden. De korpsbeheerder blijft tegenover het regionaal college verantwoordelijk voor

850. "Problemen in de competentic- of concurrentiesfeer zullen zich gaan voordoen." Elzinga, Van Rest en De Valk, 1994, p. 374.

851. 1994, p. 376. 
het optreden van de korpschefs en de lokale politiechefs zodat controle over deze politiefunctionarissen via de korpsbeheerder mogelijk blijft.

Aan de burgemeesters kan op grond van art. 36 Policiewet 1993 een aantal beheersbevoegdheden gedelegeerd worden. Hierdoor verkrijgen gemeenteraden de mogelijkheid hun burgemeester aan te spreken op zijn beheerstaken. Ook het regionall college kan gecontroleerd worden door de gemeenteraad. De controle betreft de mogelijkheid van de gemeenteraden administratief beroep in te stellen bij de commissaris van de Koningin.

De ministers van Justitie en Binnenlandse Zaken hebben de mogelijkheid gebruik te maken van hun bevoegdheid om aanwijzingen te geven aan de korpsbeheerders. Ook budgettaire controle is mogelijk door de minister van Binnenlandse Zaken, in overeenstemming met de minister van Justitie.

De klachtenregeling in de Politiewet tenslotte is een controlemiddel, waarmee klachten tegen agenten onderzocht kunnen worden.

Concluderend kunnen we over de Nederlandse Politiewet stellen dat in de wet voldoende mogelijkheden zijn opgenomen om controle over de politie uit te oefenen. Zowel op het gebied van gezag als beheer is regionaal en op rijksniveau controle mogelijk.

De controle is echter niet geheel doorzichtig. Dit wordt enerzijds veroorzaakt door de grote verscheidenheid aan controleinstrumenten en anderzijds door een relatief groot aantal organen dat controle kan uitoefenen. Daarnaast verplicht de Politiewet 1993 tot samenwerking in het driehoeksoverleg en het regional college. Het is de vraag of lokaal bestuur en openbaar ministerie steeds eensgezind tot besluitvorming zullen komen, hetgeen, wanneer de overeenstemming niet bereikt wordt, ten koste kan komen van een goed beheer en/of gezag. Toch moeten de controlemogelijkheden die genoemd worden in de Politiewet m.i. niet gezien worden als dé garantie tegen verzelfstandiging van de Nederlandse politie. Boek ${ }^{852}$ merkt terecht op in zijn boek dat de toekenning van cumulerende en verstrekkende bevoegdheden en de acceptatie dat de politie in het geheim opereert meer ruimte aan de politie biedt om te verzelfstandigen dan de afwezigheid van rechtstreekse democratische controle.

\subsection{Waarom een nieuwe organisatie?}

De toename van de (veelvoorkomende kleine en bovenlokale) criminaliteit, de toename van de internationale criminaliteit, de groeiende mobiliteit in de 
samenleving, de stijgende kosten van personeel en materiaal en een verhoogd gevoel van onveiligheid onder burgers zijn de hoofdredenen geweest om het politieapparaat een andere structuur te geven. ${ }^{853}$ Realisering van de genoemde argumenten zou moeten leiden tot een doeltreffender organisaw tie van de politie.

Het wordt niet meer als voldoende ervaren dat samenwerking tussen de politiekorpsen als de oplossing problemen voorkomt en oplost. Samenwerking tussen politiekorpsen tot nu toe vond wel in grote mate plaats maar vroeg toch ook wel veel overleg tussen de korpsen onderling. Daar was tijd en dus geld mee gemoeid en leek bovendien weinig efficiënt. Bovendien had ieder klein korps specialisaties in huis die well nodig doch niet vaak gebruikt werden. Een andere structuur zou kunnen leiden tot een effectiever politieoptreden. ${ }^{854}$ In de Memorie van. Toelichting wordt het aldus geformuleerd: "... dat de kwaliteit en doelmatigheid van de politiezorg onontkoombarar een samenvoeging van de thans nog zo verbrokkelde organisatie van de Nederlandse politie in grotere verbanden vergen. ${ }^{355}$ Dit laatste is met name het geval indien door de nieuwe structuur samenwerking met andere politiekorpsen en overheidsinstellingen en met het publiek beter gaat verlopen. In de Memorie van Toelichting wordt dan ook gesproken over één politie. ${ }^{856} \mathrm{De}$ vorm van de doeltreffender organisatie bestaat wooral uit een schaalvergroting en een centralisatie. ${ }^{857}$

De Memorie van Toelichting op de Politiewet 1993 verwijst naar de situatie elders in Europa met als voor Nederland het belangrijkste voorbeeld Enge-

853. Volgens de nota Een nieuw politiebestel in de jaren ' 90 zou ook het carrièreperspectief van de agenten verbeterd worden. 1989-1990, 21461, nr. 2, p. 3 en 17-18. "Door de grootte van die korpsen is het bijvoorbeeld meer dan thans in de kleinere korpsen het geval is, mogelijk een loopbaanbeleid te ontwikkelen. Ook zal in beginsel een grotere verticale doorstroming mogelijk zijn.. "De eerste paar jaar zal tijdelijk van doorstroming maar een volgende baan niet veel sprake zijin.

$T K, 1989-1990,21461$, nr. 2, p. 4; $T K 1991-1992,22562$, nur. 3, p. 3; Portegies-Damave, 1994, p. 512.

854. "... dat de politie beter zal functioneren als zij op andere wijze wordt georganjseerd dan tot nu toe het geval is.' Een nieuw politiebestel in de jaren '90. TK, 1989-1990, 21461, n. 2, p. 1, 3. De ervaringen met samenwerking werden door de korpsen positief ervaren. Zie ook Cachet, Van Sluis, Van der Torre, 1993, p. 12.

855. TK. 1991-1992, 22562, nr. 3, p. 4.

856. TK, 1991-1992, 22562, nr. 3, p. 5; zie ook Redactioneel, Eén politie: 27 korpsen, 1993 , P. 249.

857. Er zijn 25 regiokorpsen, een landelijk politiekorps en een militair politiekorps. Artikel 4 Politiewet 1993. 
land en Wales waar slechts 43 politiekorpsen zijn op een inwonertal van ruim 57 miljoen. 'Gelet ook op de schaal van de organisatie van de politie in de ons omringende landen - wij wijzen bijvoorbeeld op Engeland en Wales waar de politie in 43 grote korpsen is gereorganiseerd - is het uitgesloten dat Nederland een dermate versplinterde politieorganisatie zou kunnen handhaven als thans (dit is dus voor 1993, $\mathrm{Cr}$ ) bestaat. ${ }^{{ }^{858}}$ Men suggereert daarmee dat het in Engeland en Wales met de politiesamenwerking en de bestrijding van (internationale en) bovenlokale criminaliteit goed gaat. Verwijzing naar onderzoek of studies over deze punten is in de Memorie van Toelichting achterwege gebleven. Dat is jammer, want onderzoek waaruit zou blijken dat de misdaadbestrijding en andere facetten van politiewerk in Engeland en Wales efficiënter en effectiever verloopt, zou een extra argument zijn geweest voor de reorganisatie. Op grond van het feit dat in Engeland en Wales 43 grote korpsen bestaan en op grond van de gegevens in de vorige alinea werd het aldus uitgesloten geacht dat wij in Nederland Rijkspolitie en Gemeentepolitie zouden kunnen handhaven. Is het eerste argument echter wel houdbaar als wij het plaatsen tegenover de situatie in andere Europese landen?

\subsection{De politieorganisatie in andere Europese landen}

Als we kijken naar de organisatie van de politie in enkele landen in Europa, dan krijgen we het overzicht van het volgende schema te zien. Gaan we het overzicht na, dan constateren we dat Nederland lang niet alleen stond met een verdeling in de politiediensten. Zo'n verdeling lijkt zelfs de normaalste zaak van de wereld te zijn. Alleen Ierland en Denemarken kennen een pollitiebestel dat slechts bestaat uit één soort politie. Wanneer we de geschiedenis van Europa bestuderen dan hoeft dat geen verbazing te wekken. De verschillende soorten politiekorpsen in Europa zijn opgericht een tiental jaren na de Franse revolutie van 1789. De invloed van Napoleon Bonaparte is vooral te bespeuren in de landen rond Frankrijk. ${ }^{859}$ In Denemarken, Ierland en Engeland is Napoleon nooit geweest vandaar de aanwezigheid van een enkel politiekorps daar.

Napoleon wilde dat de politiekorpsen in de landen die hij bezet had, hetzelfde gestructureerd werden. Naast de gewone ("gemeente-" of landelijke) politie ontstond derhalve in veel landen tevens een militaire politie ${ }^{860}$. In

858. TK, 1991-1992, 22562, nr. 3, p. 4.

859. Dit kwam met mame door het feit dat Napoleon deze landen wilde inlijven bij het Franse Rijk. Fijnaut, 1979, p. 1126-1127.

860. Die bovendien van spionnen gebnik maakte. Het gebruik van spionnen vond al ruim voor Napoleon plaats bij de Parijse politie. Bij de spionage werden de 
Nederland betekende dat de vorming van een gendarmerie, de latere 'Rijkspolitie: ${ }^{861}$ We mogen hierbij niet uit het oog verliezen dat de oprichting wan de politie in de $18 \mathrm{de}$ en de $19 \mathrm{de}$ eeuw voornamelijk een middel was voor de overheid om de burgers onder controle te houden ${ }^{862}$ en de orde te handhaven. Dat gold ook woor een land als Engeland. ${ }^{863}$

\begin{tabular}{|c|c|c|}
\hline LAND & POLITIE & SOORT POLITIE \\
\hline België & $\begin{array}{l}\text { Rijkswacht } \\
\text { Gemeentepolitie } \\
\text { (Parketpolitie) }\end{array}$ & $\begin{array}{l}\text { National-regionaal/ } \\
\text { stedelijk }\end{array}$ \\
\hline Duissland & $\begin{array}{l}\text { Landespolize } \\
\text { Bundpolizei }\end{array}$ & $\begin{array}{l}\text { Nationaal-regionaal/ } \\
\text { stedelijk }\end{array}$ \\
\hline Frankrijk & $\begin{array}{l}\text { Police Nationale } \\
\text { Gendarmerie Nationale } \\
\text { Police Municipal }\end{array}$ & $\begin{array}{l}\text { Nationaal-regionaal/ } \\
\text { stedelijk-militair }\end{array}$ \\
\hline Denemarken & Rigspolitiet & Nationaal \\
\hline Italiè & $\begin{array}{l}\text { Arma dei Carabinien } \\
\text { Polizia di Stato } \\
\text { Guardia di Finanza } \\
\text { Vigili Urbani }\end{array}$ & $\begin{array}{l}\text { Nationaal-regionaal- } \\
\text { militair }\end{array}$ \\
\hline Spanje & $\begin{array}{l}\text { Cuerpo Nacional de Policia } \\
\text { Guarda Civil } \\
\text { Policia Aunonomica } \\
\text { Municipal Police Corps }\end{array}$ & $\begin{array}{l}\text { Nationaal-regionaal- } \\
\text { militair }\end{array}$ \\
\hline Ierland & Garda Siochana (Gardaf) & Nationaal \\
\hline
\end{tabular}

Bron: Benyon, Turnbull, Willis, Woodward, Beck, 1993, p. 67.

$860 . \rightarrow$

dienstmeisjes en de lakeien ingeschakeld. Ten tijde van Napoleon en Joseph Fouché, de minister van de algemene politie (ca. 1800), werden de tipgevers uit alle lagen van de bewolking gerecruteerd. Corruptie onder de politie was trouwens een zeer normal verschijnsel, maar juist deswege een zeer gewilde positie. Fijnaut, 1979, p. 536-537, 554-556, 749, 756, 762, 778 .

861. In 1805 werd er een eerste korps gens d'armes van 80 man sterk opgericht, ter bestrijding van de smokkel. De gendarmerie werd ondergebracht bij het ministerie van Oorlog. Fijnaut, 1979, p. 806-813. In 1810 werd officieel een tweedeling gemaakt in de politiekorpsen: een landelijke politieorgarisatie naast een plaatselijke politie bij het Keizerlijk Decreet van 18 oktober 1810 . Perrick, 1982 , p. 13 .

862. Het beheersen van de mob of bepaalde categorieën van de bevolking. De twee verschillende politiekorpsen was ook handig in de "verdeel en heers" strategie en de openbare orde-handhaving. Fijnaut, 1979, p. 537, 552-554.

863. Fijnaut, 1979 , p. 1132. Natuurlijk kunnen we dit tegenwoordig niet meer zo nadrukkelijk stellen. 
Terwijl dus vroeger in veel landen een onderscheid in de structuur van het politieapparaat bestond ten dienste van de machthebbers ter controle van de bevolking, zien we tegenwoordig een zelfde verscheidenheid met als doel het politieapparaat zelf onder controle te houden. '... (E)en politie-apparaat onder het gezag van één bewindsman strookt in ons land niet met de historische ontwikkeling, noch met de volksaard die over het algemeen afkerig is van concentratie van macht; ... een duidelijke afbakening van het gezag over de politie is om die reden een eerste vereiste;'. ${ }^{664}$

Had Nederland om de reden dat 'gelet ook op de schaal van de organisatie van de politie in de ons omringende landen ... is het uitgesloten dat Nederland een dermate versplinterde politieorganisatie zou kunnen handhaven als thans bestaat' wel een ander politiekorps nodig? Wanneer als argument gebruikt wordt dat het politieapparaat in thet buitenland ook anders geregeld is, komt de zwakte van het argument uit het hierboven getoonde schema naar voren. Uit het schema blijkt dat het spreken over een nationale politie juist helemaal niet zo vanzelfsprekend is. Dit zou anders zijn als de andere landen net als Nederland zouden overwegen het onderscheid tussen nationale en regionale korpsen op te heffen. Het voorbeeld van Engeland en Wales, zoals in de Memorie van Toelichting aangehaald wordt, is bovendien misleidend. Immers, deze korpsen zijn onafhankelijk, iets dat wij bepaald niet willen hebben.

\subsection{Een efficiënte organisatie?}

Het doel van de reorganisatie was, zoals hierboven al aangegeven, het creëren van een doeltreffender politie, die adequaat zou kunnen reageren op de naar verluidt sterk toegenomen (internationale en georganiseerde) criminaliteit. Het probleem dat ontstaat wanneer men zich een dergelijk doel voor ogen stelt is dat doeltreffendheid op dit gebied niet te meten valt. Zeker niet als niet van te voren uitgewerkt is in welke mate en op welke terreinen de politie doeltreffender zal gaan functioneren. Het zal zeer moeilijk aan te tonen zijn dat tengevolge van de reorganisatie de criminaliteitsbestrijding met een bepalald percentage verbeterd is. Andere factoren kunnen ook van invloed zijn geweest.

\subsubsection{Korpsgrootte-efficiëntie}

Winst op het terrein van de efficiëntie zal vooral te vinden zijn wanneer het betreft daling van algemene overheadkosten, de verminderde aanschaf van dure apparatuur en efficiëntere inzet van specialisten vanwege een kleiner 
aantal korpsen. ${ }^{85}$ Grotere politiekorpsen betekenen echter niet automatisch. dat er efficiënter gewerkt gaat worden. ${ }^{860}$ Een grotere organisatie houdt vaak meer bureaucratie aan de top in ${ }^{867}$ Het zal waarschijnlijk moeilijker worden om snel iets te bereiken vanwege het bureaucratisch proces. Het werkterrein wordt groter, d.w.z. de politieregio's krijgen een grotere omvang waardoor de aanrijtijden ${ }^{868}$ ook zullen toenemen. ${ }^{869}$ Onderzoek van het Sociaal en Cultureel Planbureau heeft aangetoond dat de optimale organisatie-grootte rond de 200 arbeidsjaren ${ }^{870}$ ligt. ${ }^{871}$ Zelfs het kleinste nieuwe politiekorps zal al gauw het dubbele aantal mensen in dienst hebben.

865. Redactioneel, Verzelfstandiging van de politie?, 1993, p. 289; Reenen, van, 1993 , p. $27-28$; Bruinsma, 1994 , p. 374.

866. Cachet, Rosenthal, 1992, p. 21; Bruinsma, 1994, p. 373: 'Efficiënt werken betekent niet altijd dat ook effectief wordt gewerkt, ...

867. Bruinsma, 1994, p. 378-379; Van Oudheusden, 1993, p. 94.

868. Dat wil zeggen de tijd die een politieauto nodig heeft om bij een ongeval of geconstateerd strafbaar feit te komen. In de provincie Friesland is men in april 1996 to de conclusie gekomen dat de reorganisatie voor deze provincie niet goed uitgepakt heeft. De aanrijtijden zijn te lang, er zijn te weinig agenten en de afstand tussen burger en politie is vergroot. De ministerrad zou zich gaan beraden op welke wijze de nadelige gevolgen wan de reorganisatie verholpen kunnen worden.

869. Zo blijkt uil onderzoek dat de gemeentepolitie productiever werkt dan de rijkspolitie die vaak een grotere werkregio hebben. Goudriaan, Van Tulder, Blank, Van der Torre, Kuhry, 1989, p. 161-162, 176-177. Bovendien ging de reorganisatie samen met de PKP-operatie (Project Kwantificering Politiesterkte). Hierdoor werd de politiesterkte opnieuw verdeeld over het land. Vaak is dit ten koste gegaan van de landelijke gemeenten. Door de PKP-operatie kregen de grote steden meer agenten toegewezen, hetgeen ten koste ging van de kleinere gemeenten. Daardoor zijn de kleinere gemeenten in problemen geraakt, waul al is het aantal agenten in hun gemeenten afgenomen, de criminaliteit is dat niet. De kleinere gemeenten zijn mu genoodzakikt om ò agenten te "huren" valu de nabijgelegen grotere sieden of om een eigen bewakingsdienst op te zetten, betaald uit hun eigen middelen. Het ligt woor de hand dat dit laatste idee de politic niet zal aanstaan, omdat de gemeentelijke bewakingsdienst wel eens goedkoper zou kumen zijn en bovendien een concurrent vormt voor de politie. Bos, 1994, p. 29, 33, Van Reener, 1993, p. 22-23.

870. Onder een arbeidsjaar word verstaan: "De inzet van eén personeelshid op voltijdsbasis gedurende één jaar of een daarmee vergelijkbare inzet van personeelsleden in deeltijd. Zo tellen twee werknemers voor halve werktijd in principe voor éen arbeidsjaar." Goudriaan, Van Tulder, Blank, Van der Torre, Kuhry, 1989 , p. 273.

871. Goudriaan, Van Tulder, Blank, Van der Torre, Kuhry, 1989, p. 161-162; zie ook Tulder, 1992, p. 74-75; Van Reenen, 1993, p. 26-28. 
Samenwerking tussen de korpsen zall ondanks de samenvoeging van diverse korpsen, onverminderd nodig zijn. Immers, regionale criminaliteit blifft niet altijd binnen de grenzen van ến regiokorps. Dit is met name het geval indien criminelen werkzaam zijn op de grens van twee of meer politieregio's.

Of mel de nieuwe korpsgrootte de efficientie toe zal nemen is nog maar de wraag. Eerder lijkt hier sprake wan een grootschalig bureaucratisch experiment. Voor de mensen binnen de organisatie betekent de reorganisatie onrust en onzekerheid. Op dit moment wordt alweer gesproken over het samenvoegen van regiokorpsen tot provinciekorpsen, alweer met Engeland en Wales als voorbeeld, waar de gemiddelde korpsgrootte veel groter is dan in Nederland. ${ }^{872}$ Voor een conservatieve instelling als de politie houdt dit wooruitzicht nog meer onrust en onzekerheid in. ${ }^{873}$

\subsection{2 'Reform without a scandal is no reform'}

We kunnen stellen dat een hervorming meestal een tweetal beoogde doelen met zich meedraagt: een verhoogde effectiviteit en een verhoogde efficientie. In het kader van die doelen worden er maatregelen genomen om die doelstellingen te bereiken. Die maatregelen kunnen zijn: een beter toezicht. door hogere of onafhankelijke instanties, andere procedures, aangescherpte wetgeving en ander beleid. Blijwen de maatregelen achterwege of brengen ze nauwelijks verandering, dan stelt de hervorming niet veel voor. Dan heeft er slechts een hervorming op papier plaatsgevonden, maar in de praktijk geen effect gesorteerd zoals we ook diverse keren in Engeland en Wales zagen. Wanneer we de Memorie van Toelichting en de wet erop nalezen dan vinden we geen eisen of maatregelen die tot de nieuwe gestelde doelstellingen kunneri leiden. Zelfs een analyse van de problemen ontbreekt. Nergens vraagt men zich af wat de oorzaken van de gesignaleerde problemen zijn en op welke wijze de gekozen oplossing het probleem zall doen verdwijnen. ${ }^{8 \% 4}$ Het lijkt erop dat de regering van mening was dat de reorganisatie op zich al tot het gewenste resultaat zou leiden. Die laatste conclusie kan men betwijfelen.

Een systeem kan op twee manieren veranderen: via de politiek/bestuurlijke weg (systeem benadering) zoals dat nu in Nederland gebeurt, of na het

872. In Engeland on Wales waren in 1992127.600 agenten verdeeld over 43 politiekorpsen. Voor Nederland zijn de aantallen: 26 korpsen en 49.500 agenten. Benyon, Turnbull, Willis, Woodward en Beck, 1993, p. 67.

873. Vg!. Wilders, 1994, p. 12-15.

874. Van Reenen, 1993, p. 8-10. 
uitkomen wan een schandaal (symptoom benadering) zoals in Engeland en Wales. ${ }^{875}$ Zijn beide manieren even effectief of is er een verschil?

Leidt het veranderen van een systeem zonder dat daarwoor een valide reden is aan te wijzen wel daadwerkelijk tot een verandering? Laten we weer naar de Politiewet 1993 kijken. Op pagina 1 van de Memorie van Toelichting lezen we: "De bestaande regeling van het gezag en het toezicht over de politie, haar taken en bevoegdheden, het driehoeks- overleg enz. blijft ongewijzigd. ${ }^{876}$ Verder wordt gesteld: "De discussie over de vraag door wie het gezag over de politie moet worden uitgeoefend en hoe de bevoegdheden van burgemeester en officier van justitie dienaangaande zich onderling verhouden lijkt thans definitief tot het verleden te behoren en wordt door het hier besproken wetsontwerp ook niet opnieuw opgerakeld. Openbaar Ministerie en lokaal bestuur hebben elkaar in het belang van de politie weten te vinden en in de praktijk het vroeger zo omstreden gezagsdualisme weten om te buigen tot een gemeenschappelijke beleidsvorming en daarop afgestemde besluitvorming. Hetzelfde geldt voor de regeling van het toezicht op de politie door de commissaris der Koningin en de procureur-generaal bij het gerechtshof. Ook over de inhoud van de politietaak, al zo pakkend verwoord in artikel 28 van de Politiewet van 1957, en het onderscheid tussen wat nu genoemd wordt de handhaving van de openbare orde en de strafrechtelijke handhaving van de rechtsorde, bestaan thans geen wezenlijke verschillen van inzicht meer, ${ }^{877}$

875. Zie onderstaand schema.

876. TK, 1991-1992, 22562, nr. 3.

877. TK, 1991-1992, 22562, nr. 3, p. 3. 


\section{Schandaal}

Clean-up. Een systeem veranderen op deze manier gebeurt op een zichtbare manier en met een zeer duidelijk doel. Daarmee word bedoeld dat het schandaal in het openbaar bespreekbarar is en hef doel van de verandering voor een ieder duidelijk is. Daarna komt echter de bureaucratie aan de beurt, waardoor het probleem traag verholpen kan worden. Dit hoeft echter niet.

\section{Besuurlijk/politiek}

Deze manier is traag en van het begin af bureaucratisch vanwege de langzame werkwijze van commissies. Het leidt ook onherroepelijk tot compromissenvorming wardoor het eigenlijke doel bijna nooit volledig gehaald wordt. Vooral omdat ook niet altijd duidelijk is wat het eigenlijke doel is.

De grote steden klaagden al geruime tijd over de criminaliteitsoverlast en de onderbezetting. De problemen op het gebied van de interregionale en internationale misdaadbestrijding werden in de media en in het politiek debat als de belangrijkste reden opgegeven voor de reorganisatie. Het sleutelwoord werd samenvoeging. ${ }^{878}$ En als vanzelfsprekend zall de reorganisatie tot een verhoogde samenwerking leiden! (sic!) Immers dan is er een groter politiekorps.

878. TK, 1991-1992, 22562, nar. 3, p. 4. 


\subsubsection{Conclusie}

'Het risico bestaat dat er alleen op papier gereorganiseerd wordt. "\$27

' $\mathrm{k}$ heb hel gevol dat de echte reorganisatie nog maet beginnen terwijl anderen zeggen dat de reorganisatie bijna is afgerond. Ik denk dar er slechs mensen zijn verplaatst. Als binnenkort blijkt dat de zaken niet goed draaien zal men de juiste mensen op de juiste plaatsen moeten zetten (echte reorganisatie). "sos

Door de reorganisatie werd de politieorganisatie veranderd. Het werk en de mensen ondergingen echter geen wijziging. "Toch bepalen juist deze factoren of de politietaken effectiever en efficiënter uitgevoerd worden. Met de Politiewet 1993 veranderde als het ware alleen het omhulse1, maar de aard van het werk, de manier van aanpak, de mogelijke 'rotte appels' binnen het apparaat en de invloed van de politiecultuur werden geen direct onderwerp van aanpak. Al deze facetten kunnen een rol spelen in de bestrijding van de criminaliteit. Wat we straks zullen zien is dat deze vier factoren zich hebben aangepast aan de nieuwe organisatie. Agenten hebben even tijd nodig om te ontdekken wie hun nieuwe werkbaas is, wie nu over de apparatuur gaat, bij wie ze hun beklag moeten doen en hoe de werkregio nu ingedeeld is. Het eigenlijke werk, de collega's, de politiecultuur en in zekere zin de structuur blijven ongewijzigd. Is van een dergelijke reorganisatie wel vooruitgang te verwachten?

\subsubsection{Efficiëntie en effectiviteit}

Er kunnen veel vraagtekens gezet worden bij de haalbaarheid van de beoogde doelen efficiëntie en effectiviteit. ${ }^{882}$ De nieuwe organisatie is en zal ook reden zijn voor interne problemen. Er zijn nu minder bazen en onderbazen binnen het korps dan voor de reorganisatie. ${ }^{83}$ Alle agenten hebben op-

879. Van Oudheusden. 1993, p. 93.

880. H. Bijen in Stichting Maatschappij en Politie, 1995, p. 64.

881. "An adequate approach to police reform must be grounded in an understanding of police culture and practices, not a simplistic view that if only the right authorities were in charge all would be well.' Reiner, 1985, p. 198; Vgl. ook Bruinsma, 1994, p. 376, die schrijft: “... is schaalvergroting bij de politie uiterst eenzijdig uitgevoerd: Schalwergroting komt neer op het bij elkaar optellen van het bestaande. Ruimte voor innovatie en verandering bestaat er op korte termijn nauwelijks, waardoor mag worden aangenomen dat de politie op dezelfde oude, traditionele weg zal voortgaan, alleen dan in groter verband."

882. Afgezien wan het feit dat elke nieuwe structuur ook inwerktijd nodig theeft. Vgl. ook Bruinsma, 1994, p. 368-381.

883. Met name de korpschefs van de vier grote steden hebben goede zaken gedaan. 
nieuw naar een (hun) baan moeten solliciteren in de hoop dat zij hun/een begeerde baan respectievelijk zouden behouden of krijgen. Voor veel ervaren agenten zal het carrierevooruitzicht achteruit gegaan zijn wat zeer zeker tot spanmingen leidt. ${ }^{80 k e r}$ de eerste jaren zal er van toekomstige carrièreplanning binnen het politieapparaat niet veel te bespeuren $\mathrm{zijn}{ }^{385}$ Darnaast bestaat thet gevaar dat de sfeer binnen het korps onpersoonlijker zal worden ondat de korpsen groter en groter worden en mensen vaker en verder weg overgeplaatst worden. Wil men dan iets bereiken, dan is men meer afhankelijk van het informele circuit. Aangezien de reorganisatie van de politie wooral een interne kwestie was, kan men zich afvragen of de verwachtingen van effectiviteit en efficiëntie, die voornamelijk naar buiten gericht waren - te weten een verbetering van de bestrijding van de criminaliteit -, wel haalbaar waren. ${ }^{886}$

\subsubsection{Systeem- of symptoombenadering?}

Er zijn twee manieren om een verandering van een systeem te bereiken. Aan de ene kant is er de verandering zonder dwingende noodzaak - de bureaucratische wijze -, en aan de andere kant kan de verandering geschieden via een schandaal. De laatstgenoemde wijze van verandering heeft volgens Sherman de meeste kans van slagen orndat het herkenbare doelen creëert: zo'n schandaal mag nooit meer woorkomen. Een verandering, gebaseerd op een schandaal schept zijn eigen legitimiteit. De mensen willen en moeten dan meewerken.

Bij de bureaucratische reorganisatie is die legitimiteit veel minder. Het komt meer over als willekeurig en kan aldus de loyaliteit ten opzichte van de organisatie aantasten. Terwijl de politiereorganisatie van 1993 gezien kan worden als een bureaucratische verandering wil ik in het volgende hoofdstuk twee Nederlandse schandalen bespreken: de rellen in Amsterdam en de IRTzaak.

Zij zijin alle vier niet alleen op hun post gebleven, ze hebben ook veel meer mensen gekregen.

884. Zelfs als dat niet $z 0$ is, is er toch nog veel dissatisfactie. Dat agenten het moeilijk hebben met de reorganisatie valt te lezen in enkele redactionele stukjes van het Tijdschrift wan de Politie, bijy. in 1993, p. 249, 1993, p. 45 en 1992, p. 437; Höfte, 1993, p. 91, Grat van den Heuvel in Het Parool, 1 juni 1994, 'De jaren-Hirsch Ballin waren vooral chaotisch'.

885. Redactioneel, De pija van veranderen, Tijdschrift voor de Politie, 1992, p. 437; Bruinsma, 1.994 , p. 375.

886. Cachet, 1993, p. 22-27. Ook Bruinsma is niet erg optimistisch over een verbetering van de effectiviteit en de efficiëntie. Bruimsma, 1994, p. $379-380$; $\mathrm{Vgl}$. Bos, 1994, p. 28-33. 


\title{
12 De controle over de Nederlandse politie
}

\begin{abstract}
"Maar waarom hebben we eigenlijk nog een wetboek van strafvordering? Kennelijk niet meer om onder alle omstandigheden het handelen wan de overheid te normeren: die trekt zich wan de owerheid niet al te weel aan.
\end{abstract}

\subsection{Inleiding}

Voor de situatie in Engeland en Wales heb ik betoogd dat een politiedienst zonder verantwoordingsplicht een negatief effect kan hebben op de legitimiteit van het politieoptreden en het vertrouwen van de burgers in de politie. Toezicht en controle zouden dit kunnen verhelpen. Om te zien of deze 'stelling' enigszins opgaat - in tegenstelling tot Engeland en Wales heeft Nederland immers geen onafhankelijke politie $e^{888}$-, behandel ik in dit hoofdstuk twee Nederlandse schandalen die kunnen aantonen of controle de oplossing biedt ter voorkoming van problemen of schandalen.

We kunnen niet ontkennen dat er in Nederland ook problemen zijn met een politie die zo nu en dan op eigen houtje te werk gaat. In de afgelopen jaren is de politie weleens in opspraak gekomen vanwege de wijze van haar optreden. Engeland en Wales staan dus daarin niet alleen. In Engeland en Wales echter is de politie onafhankelijk, hetgeen een historische, politieke keuze is geweest. Voor Nederland geldt dit niet. In Nederland is de politie ondergeschikt aan het bevoegd gezag: de burgemeester/korpsbeheerder en de officier van justitie. Ondanks het bestaan van dit gezag zijn er 'schandalen' geweest. Twee schandalen wil ik hier met name noemen: de rellen in Amsterdam in 1966 en de IRT-zaak in 1994. Daarmee wil ik niet aangeven dat er slechis twee schandalen zijn geweest. Naast deze twee schandalen kent Nederland 0.a. de rellen in 1966 in Amsterdam rond het huwelijk van (toen nog) Prinses Beatrix, de activiteiten van Provo, de studentenprotesten, de ophef rond de methode Koppenjan en de acties van de ME (Mobiele Eenheid). Om dicht bij de Engelse casuïstiek te blijven heb ik gekozen woor ean schandaal in de jaren zestig - ongeveer ten tijde van het eerste voorbeeld van Engeland en Wales - en een schandaal dat qua periode ongeveer samenvalt met het laatste Engelse schandaal dat ik behandel. De keuze is willekeurig geweest, doch voor wat betreft het tweede Nederlandse schandaal, niet

887. De Doelder, 1994. p. 541.

888. Over een vergelijking tussen de politie in Engeland en Wales en Nederland maakt Boek, 1996, p. 32, noot 42, de opmerking: 'Met name het stelsel waarim de politie in Engeland en Wales is georganiseerd, wertoont verwantschap met het regionale Nederlandse politiebestel. De zelfstandigheid die de politie daarin heeft, lijkt onnederlands, maar maakt een vergelijkend onderzoek juist zo interessant." 
geheel. Bij beide gebeurtenissen stond een politie die zonder overleg beslissingen nam, centraal. En bij beide gebeurtenissen is de vraag hoe het zover had kunnen komen en hoe de organisatie (en/of de overheid) reageerde op dit schandaal.

In dit hoofdstuk gat het over de controle over de politie in de praktijk ${ }^{8.94}$ Eerst bekijk ik waarom controle nodig is. Daarna bespreek ik de bowengenoemde rellen in Amsterdam en het IRT-schandaal. Daamaast ga ik na of de politiereorganisatie van 1993 bijdraagt tot een betere controle over de politie.

\subsection{Bevoegdheden en de noodzaak tot controle}

'De politie heeft tot taak in ondergeschiktheid aan het bevoegd gezag en in overeenstemming met de geldende rechtsregelen te zorgen voor de daadwerkelijke handhaving van de rechtsorde en het verlenen van hulp aan hen, die deze behoeven', aldus artikel 2 van de Politiewet $1993^{890}$. Met de handhaving van de rechtsorde wordt zowel bedoeld de handhaving van de openbare orde als de strafrechtelijk handhaving van de rechtsorde. Uit dit artikel kan afgeleid worden dat de politie de oude dubbele taak heeft behouden, namelijk het beschermen wan de maatschappij en het verlenen van hulp. ${ }^{891}$ Voor het vervullen van haar taken heeft de politie de mogelijkheid gebruik te maken van diverse dwangmiddelen. Deze dwangmiddelen moeten adequaat gebruikt worden. De burgers in de maatschappij zouden niet willekeurig slachtoffer mogen worden van de toepassing van de dwangmiddelen. Het gebruik van deze middelen is daarom aan regels gebonden die ook wettelijk zijn vastgelegd. Gewaakt moet worden dat deze bevoegdheden niet overschreden worden, d.w.z. dat er geen misbruik van gemaakt wordt. ${ }^{892}$ Vandaar dat controle noodzakelijk is. Openbaar Ministerie en korpsleiding moeten daar in de eerste plaats voor zorgen. Als gezagsdragers behoren burgemeester en officier van justitie in afdoende mate toezicht te houden.

\subsection{Rellen in Amsterdam}

In de Politiewet 1993 wordt in verschillende artikelen de samenwerking centraal gesteld tussen politie, burgemeester en officier van justitie. Het driehoeksoverleg is naar aanleiding van de gebeurtenissen in 1966 in het

889. Zie voor een interessante bespreking van controle over de politie in de jaren 1957-1980 het artikel van Van Outrive, 1981.

890. Crr. artikel 28 Politiewet 1957.

891. De justitiële en de openbare orde taak.

892. Zie ook Cachet, Van Sluis, Van der Torre, Rosenthal en Muller, 1993, p. 3738: Bescherming 'tegen' de politie. 
leven geroepen om tegen te gaan dat de politie zelfstandig zou gaan optreden. Laten we voor een goed inzicht even terugblikken naar 1966.

\subsubsection{Juni 1966}

In mei 1966 werd door de Stichting Wcantiefonds voor de Bouwnijverheid aan bouwvak-werknemers aangekondigd dat er vanwege administratiekosten $2 \%$ gekort zou worden op de vakantie-uickering van werknemers. ${ }^{893}$ Werknemers die in een vakbond georganiseerd waren, konden dit geld terugkrijgen via hun wakbond. De werknemers gingen niet accoord met deze maatregel en probeerden via overleg met de directie de maatregel in te laten trekken. Aan dit verzoek van de werknemers werd geen gehoor gegeven. ${ }^{894}$ Op de avond van 13 juni zou het vakantiegeld aan een deel van de bouwvakkers uitgekeerd worden. Er kwamen echter meer mensen opdagen om de witbetaling te sabotteren. Dit had tot gevolg dat er hier en daar kleine verstoringen van de orde voorkwamen. Tijdens het verspreiden van de menigte door de politie overleed de heer Weggelaar. Later bleek dat hij een natuurlijke dood gestorven was. Op het moment dat het gebeurde werd echter door publiek en media aangenomen dat de man door politiegeweld overleden was. De volgende dag vond er een demonstratie plaats van bouwvakkers die uit de hand liep. Enkele gebouwen van het Sociaal Fonds Bouwnijverheid moesten het ontgelden. Het dagblad De Telegraaf had als enige de dag daarna in haar berichtgeving over de demonstratie opgenomen dat de heer Weggelaar overleden was aan een natuurlijke doodsoorzaak. Als gevolg van deze berichtgeving liep een menigte demonstranten naar het gebouw van De Telegraaf. Ter plaatse werden vrachtwagens van De Telegraaf vernield en in brand gestoken. Ook elders in de stad Amsterdam werd nog de rest van de dag gedemonstreerd en werden vernielingen aangericht. ${ }^{89.5}$

\subsubsection{Commissie van onderzoek Amsterdam}

Naat aanleiding van de rellen op 13 en 14 juni 1966 werd in juli 1966 een Commissie van onderzoek Amsterdam ${ }^{8 \%}$ ingesteld ${ }^{897}$ Deze onderzoekscommissie kreeg als taken "een onderzoek in te stellen - met name voor de periode sedert september 1965 - naar de gezagsverhoudingen ten aanzien

893. Commissie van onderzoek Amsterdam, Eerste interim-rappori, 1967, bijlage 1.

894. Commissie van onderzoek Amsterdam, Eerste interim-rapport, 1967, p. 15-19.

895. Commissie van onderzoek Amsterdam, Eerste interim-rapport, 1967, p. 19-28.

896. Ook wel de commissie Enschedé genoemd, naar haar woorzitter prolessor $\mathrm{Ch}$. J. Enschedé.

897. Dit sluit goed aan op de theorie van Shernan: Scandal and reform. Een actie van de regering na het bekend worden van een schandaal. 
van de handhaving van de openbare orde in Amsterdam en van de overige daarmede samenhangende politietaken en naar het mede ter uitvoering van de op dit punt gegeven bevelen gevoerde politiebeleid", "een onderzoek in te stellen naar de organisatie en structuur van het Amsterdamse politiekorps en naar het dienaangaande gevoerde beleid' en 'een onderzoek in te stellen naar de achtergronden wan een reeks van ordeverstoringen, welke sedert omstreeks september 1965 te Amsterdam heeft plaatsgehad'. ${ }^{898}$

Uit dit onderzoek kwam naar voren dat de onderlinge samenwerking tussen politie, justitie en burgemeester in Amsterdam slecht verliep. ${ }^{859}$ Het beleid van justitie, het beleid van de politie en dat van de burgemeester liepen niet parallel. ${ }^{900}$ Ook wijzigde het beleid vaak. ${ }^{901}$ Van afdelingschefs van de politie werd gezegd dat ze te autonoom waren. Van de kant van de politie werd opgemerkt dat ze te weinig algemene richtlijnen kregen. ${ }^{92}$ De communicatie binnen het korps kon beter. De rellen op 13 en 14 juni 1966 illustreerden dat deze situatie niet kon blijven bestaan. De commissie kwam tot de conclusie dat "... in de verhoudingen zoals die te Amsterdam gegroeid zijn, de communicatie tussen de voor het beleid verantwoordelijke autoriteiten onvoldoende tot ontwikkeling is gekomen, en dat heeft een nadelige invloed gehad op het verloop van zaken.' 903 Volgens de commissie zou een goede coördinatie tussen de politie, justitie en bestuur veel problemen hebben kunnen voorkomen. "Dat daarbij aan de burgemeester een centrale plaats toekomt, is duidelijk. In de eerste plaats is deze autoriteit in de vorming zowel van het bestuurlijk-politieke beleid als van het politiebeleid betrokken. In de tweede plaats herinnert de Commissie aan haar beschouwingen omtrent de mogelijkheden en beperkingen van repressief optreden als middel ter beteugeling van verstoringen van de openbare orde. De officier van justitie is dan ook wel voor de burgemeester de onmisbare gesprekspartmer bij het opbouwen van een gecoördineerd beleid, maar de centrale figuur is hij niet; dat is de burgemeester'. ${ }^{904}$

898. Commissie van onderzoek Amsterdam, Eerste interim-rapport, 1967, p. 12.

899. Zie het voorbeeld op p. 144 wan de Commissie van onderzoek Amsterdam, Slorrapport, 1967. Zie ook Cachet, Van Sluis, Van der Torre, Rosenthal en Muller, 1993, p. 52-53.

900. Zie ook Albert, 1994, p. 31.

901. Commissie van onderzoek Amsterdam, Slorrapport, 1967, p. 146.

902. Conmissie van onderzoek Amsterdam, Tweede interim-rappor, 1967, p. 64 en 66.

903. Commissie van onderzoek Amsterdam, Slotrapport, 1967, p. 137.

904. Commissie van onderzoek Amsterdam, Slotrapport, 1967, p. 146. 


\subsubsection{Het driehoeksoverleg}

De Commissie van onderzoek Amsterdam gaf het advies dat de autoriteiten vaker en beter met elkaar moesten overleggen inzake politie-aangelegenheden. De rellen in Amsterdam uit 1966 en het rapport dat daarop volgde van de Commissie van onderzoek Amsterdam hebben geleid tot het ontstaan van het driehoeksoverleg. ${ }^{905}$ Officier van justitie, burgemeester en korpsleiding zouden voortaan om de tafel gaan zitten en het beleid op elkaar afstemmen. In dit overleg hebben de burgemeester en officier van justitie formeel de touwtjes in handen, hoewel men gelijkwaardigheid nastreeft. ${ }^{906}$ De korpschef moet er zorg voor dragen dat het beleid dat in het owerleg op elkaar afgestemd is, ook uitgevoerd wordt. ${ }^{907}$ Het driehoeksoverleg kan beschouwd worden als een feitelijk controle-orgaan ${ }^{908}$, dat toezicht op de politie houdt. In het driehoeksoverleg wordt een afweging van de belangen van de verschillende partijen gemaakt. "Men heeft elkaar nodig voor de uitoefening van ieders afzonderlijke verantwoordelijkheid (burgemeester politiek; openbaar ministerie - rechtshandhaving; korpschef - het managen van een bedrijf) ${ }^{\prime 9}{ }^{919}$ Het driehoeksoverleg heeft in de loop der jaren steeds meer aan betekenis gewonnen. Met name sinds de totstandkoming van het beleidsplan 'Samenleving en criminaliteit' in 1985 is het belang van het driehoeksoverleg meer en meer erkend. ${ }^{90}$

\subsubsection{Effectiviteit van het driehoeksoverleg}

Uit recent onderzoek ${ }^{911}$ is gebleken dat in de praktijk het driehoeksoverleg als controle-orgaan niet meer optimal functioneert. De politie ontvangt weinig sturing van dit overleg. Ook word het beleid niet voldoende gecoordineerd. ${ }^{912}$ Dit heeft tot gevolg dat de politie meer onafhankelijk wordt dan gewenst is. Het wordt aan de politie overgelaten adequaat te reageren op situaties die rechtshandhaving behoeven. De korpschef is uiteraard een deskundige op dit gebied. Hij weet welke middelen voorhanden zijn en wat

905. Het werd nader beschreven in de "Nota met vraagpunten" van 1972 . Vgl. Albert, 1994, p. 31; TK, 1967-1968, 9322, p. 3, 4; Van Outrive, 1981, p. 85; Het driehoeksowerieg is geregeld in art. 14 Politiewet 1993.

906. In het begin was het driehoeksoverleg nog vrijblijvend. Vgl. TK 1991-1992, 22562, MvT, nr. 3, p. 31; Elzinga, Van Rest en De Valk, 1995, p. 203; zie ook Staal, 1987, p. 98.

907. Albert, 1994, p. 24; Staal, 1987, p. 98.

908. Albert, 1994, p. 165.

909. Staal, 1987, p. 99.

910. Elzinga, Van Rest en De Valk, 1995, p. 201-202.

911. Albert, 1994; vgl. ook Staal, 1987, p. 99-100.

912. Albert, 1994, p. 168. 
zijn korps in bepaalde situaties kan. Hij is immers vanwege zijn ervaring in staat in te schatten wat haalbaar is. 'De politie kan buiten de formeel-juridische kaders om, zonder directe sturing door de burgemeester en de hoofdofficier van Justitie, in ruime mate haar eigen koers bepalen.' En het onderzoek toont ook aan dat "... het ontbreken van krachtig tegenspel door het OM en in mindere mate door het lokaal bestuur, de politie in een positie plaatst waarin verzelfstandiging op zijn minst tot de mogelijkheden behoort. ${ }^{, 913}$ Het is echter de vraag of het wenselijk is dat de korpschef, tegen de achtergrond van de (politieke) verantwoordelijkheid van burgemeester en hoofdofficier van justitie, eigenhandig beslissingen mag nemen die gevolgen kunnen hebben voor burgemeester en hoofdofficier van justitie. Wellicht dat het wenselijk is het driehoeksoverleg aan te passen gezien de ontwikkelingen binnen de politieorganisatie van de laatste jaren.

\subsection{Het IRT-schandaal}

Het IRT-schandaal van 1994 is een voorbeeld van een schandaal waarin een zelfstandig opererende politie-eenheid gebruik maakte van opsporingsactiviteiten die onvoldoende bekend waren bij het bevoegde gezag. Het Openbaar Ministerie verkeerde niet in de positie op efficiënte wijze leiding te geven aan de betreffende politie-eenheid. De organisatiestructuur was ondoorzichtig en complex. Controle ontbrak volledig. Gezien de context van deze studie wordt het schandaal kort behandeld.

\subsubsection{Het Interregionaal Rechercheteam}

In de jaren ' 80 en begin jaren ' 90 werd de Nederlandse politie ervan doordrongen dat de georganiseerde misdaad in Nederland niet onderschat moest worden. Na enkele misdaadanalyses bleek dat veel groeperingen in Nederland voldeden aan het begrip 'georganiseerde criminaliteit'. ${ }^{914}$ Samenwerking tussen de verschillende korpsen werd noodzakelijk geacht.

In 1989 werd de samenwerking tussen de korpsen van Amsterdam en Utrecht verwezenlijkt in het Interregionaal Rechercheteam Noord-Holland/Utrecht (IRT). Het IRT hield zich in eerste instantie bezig met een misdaadsyndicaat dat handelde in soft drugs. Teneinde zo efficiënt mogelijk te werken en lekken naar de buiten- en onderwereld te woorkomen, werd de groorste geheimhouding in acht genomen intern èn extern (het need to knowprincipe). Alleen de leiding van het IRT was van alles op de hoogte. ${ }^{915}$

913. Albert, 1994, p. 168.

914. Misdaadanalyses van 1988, 1991, 1993 en 1994. Zie Middelburg en Van Es,
1994, p. 7-8.

915. Middlelburg en Van Es, 1994, p. 20. 
Resultaten bleven echter uit, zelfs nadat het IRT de beschikking kreeg over een informant die later tevens infiltrant bleek te zijn. In de jaren dat de infiltrant woor het IRT actief was, werd onder verantwoordelijkheid van het IRT (en dus de politie) duizenden kilo's soft drugs in Nederland ingevoerd en op de Nederlandse markt gebracht. Tijdens dit onderzoek maakte de politie gebruik van inkijkoperaties en werd de infiltrant niet, zoals vereist werd, begeleid.

Intussen werd de Nederlandse politie gereorganiseerd. Dit had gevolgen woor het IRT Noord-Holland/Utrecht. ${ }^{916}$ Het IRT zou onder het regiokorps van Amsterdam gaan wallen. De werkzaamheden van het IRT waren, behalve voor een of twee mensen aan de top van het IRT, voor iedereen onduidelijk en toen deze mensen ook uit het IRT stapten, wist niemand van de nieuwe leiding waar het eigenlijk allemaal om draaide. Na enige tijd kreeg het nieuwe hoofd van het IRT pas in de gaten dat de politie en justitie te ver waren gegaan. Hij keurde de gang van zaken af ${ }^{917}$ en er werd besloten dat het IRT met deze activiteiten moest stoppen. Voor de zekerheid werd nog overlegd met de ministers van Binnenlandse Zaken en van Justitie. Ook de minister van Binnenlandse Zaken Dales ${ }^{918}$ was duidelijk in haar oordeel: "afbreken'. 919

In de eerste paar maanden van 1994 begon de pers lucht te krijgen van de IRT-zaak maar veel werd er in eerste instantie niet gepubliceerd. Pas nadat (niet bewezen) geruchten over corruptie bij het Amsterdamse politiekorps verspreid werden, pakten de media de link tussen het IRT en de corruptie snel op. ${ }^{920}$ Het IRT werd een begrip in Nederland voor ondeugdelijk poli-

916. Middelburg en Van Es, 1994, p. 101.

917. Het hoofd van het IRT Van Kastel: "Politie en Justitic gaan met als doel de criminaliteit te bestrijden in dit traject zó ver, dat zij bereid zijn een bellangrijk aandeel van de criminaliteit te organiseren. Hier is mijns inziens absoluut geen sprake meer van proportionaliteit. Naar mijn mening, is daarentegen sprake van het plegen van strafbare feiten onder regie van Politie en justitie, die niet te veramtwoorden zijn op grond wan het achterliggende belang. Hoewell ik het doel van de operatie onderschrijf, vind ik het gekozen middel grenzen ver te buiten gaan.' Middelburg en Van $E s_{*} 1994$, p. 119 . De Commissie Wierenga zou later in haar rapport (1994, p. 145-147) zich negatief uitlaten over de rol wan Van Kastel in deze zaak. Naar mijn mening geheel ten onrechte. Zo lijkt het alsof de boodschapper de zondebok werd. Zie ook. De Roos, 1994, p. 439; Het Parool, 'Verslag over IRT unfair en eenzijdig', 29 maart 1994.

918. Begin 1994 opgevolgd door Van Thijn.

919. Middelburg en Van Es, 1994, p. 129-130. Vgl. ook Taru Spronken in Trouw, "Welk doel heiligt de middelen van het IRT?', 30 maart 1994.

920. Voor het bestaan van corruptie met betrekking tot het IRT waren echter geen 
tiewerk. De Commissie Wierenga stelde een onderzoek in naar de gang wan zaken in het IRT Noord-Holland/Utrecht. In haar rapport van maart 1994 noemde de commissie als oorzaak van de opheffing van het IRT een verslechterde verhouding tussen OM en politie in Amsterdam. Het Openbaar Ministerie, burgemeester en de korpsleiding in Amsterdam zouden zonder deugdelijk onderzoek het IRT opgeheven hebben alhoewel de opsporingsmethode die door het IRT gehanteerd werd niet ontoelaatbaar was aldus de commissie. ${ }^{921}$ Het kabinet was het niet eens met de conclusies in het rapport Wierenga en steunde politie en justitie in Amsterdam. ${ }^{922}$ Toch was er een voortdurende politieke onrust, tengevolge waarvan de ministers van Binnenlandse zaken en Justitie eind mei 1994 hun ontslag aanboden. ${ }^{923}$

\subsubsection{Parlementaire enquête}

Terwijl de Commissie Wierenga een onderzoek gedaan had naar het IR $\Gamma$ Noord-Holland/Utrecht, werd in juni 1994 een commissie in het leven geroepen die een onderzoek zou instellen naar de opsporingsmethoden van de politie. ${ }^{924}$ Het schandaal leek zich derhalve uit te breiden. Niet alleen het IRT werd onderzocht, maar de leiding van het politieapparaat, het Openbaar Ministerie en de ministeries van Binnenlandse zaken en van Justitie vielen binnen de reikwijdte van dit onderzoek. Deze commissie $\mathrm{kreeg}$ de naam "Vooronderzoek opsporingsmethoden' en wordt ook wel de werkgroep Van Traa genoemd. Op 21 oktober 1994 werd door de commissie het rapport 'Opsporing gezocht' uitgebracht. De commissie adviseerde een parlementaire enquête ${ }^{925}$ om de toelaatbaarheid te onderzoeken van bepaalde opsporingsmethoden. ${ }^{926}$ In december 1994 was de enquêtecommissie een feit.

920. $\rightarrow$

concrete bewijzen, aldus het Rapport van de Bijzondere Onderzoekscommissie, 1994, p. 174; "Opheffing IRT hield geen verband met corruptiex, 1994, p. 4-6.

921. Algemeen Dagblad, 'Nog geen gevolgen voor hoofdrolspelers in IRT-zaak' en 'IRT ten onrechte opgeheven', 25 maart 1994.

922. De Wiksknant, "Verontrustend rapport" 25 maart 1994.

923. De Wilkskrant, 'Hirsch Ballin en Van Thijn stappen uit kabinet', 28 mei 1994.

924. Het resultaat van het IRT-debat van 7 april 1994, Redactie 'De nasleep van het IRT dlebat", Algemeen Politieblad, 1994, p. 12-13.

925. Zie over de functies van parlementaire enquêtes De Vries en de Groot, 1991, p. 8-19.

926. TK, 1994-1995, 23945, nrs. I en 2, p. 4. Algemeen Dagblad, 21 oktober 1994. "Commissie adviseert enquête over IRT-affaire". Tweedle Kamer en kabinet wilde in eerste instantie echter niet zover gaan, omdat het werk van politie en justitie daardoor gefrustreerd zou kumnen raken. Dezelfde mening was ook de Raad van Hoofdcommissarissen toegedaan. Trouw, 22 oktober 1994, 'Kamer is huiverig voor enquâte naar opsporing' en 'Kamer gaat niet tot de bodem'. Redactie, "Opsporingsmethoden in discussie', Algemeen Politieblad, 1994, p 4. 
Maarten Van Traa werd voorzilter. ${ }^{927}$ Op 1 februari 1996 heeft de Commissie Van Traa haar rapport uitgebracht. Het rapport is vooral ingegaan op de diverse opsporingsmethoden en de rol van het $\mathrm{OM}$.

Uit het rapport kwam naar voren dat het onafhankelijkheidsstreven van de verschillende politiediensten in de opsporing te ver was gegaan. Daarnaast was het $\mathrm{OM}$ tekort geschoten in de controle over de politiediensten. ${ }^{928} \mathrm{Zo}$ was het OM niet op de hoogte van het feitelijk handelen van de politie. Daaruit bleek dat de politie al te ver verzelfstandigd was. Maar ook het openbaar ministerie stelde zich te onafhankelijk op. ${ }^{929}$

De aanbevelingen van de commissie waren erop gericht de controle over de politie en de opsporing duidelijk en wettelijk te regelen en het gezag van het openbaar ministerie ten opzichte van de politie in het kader van de opsporing te versterken. ${ }^{930}$ De eerste reacties naar aanleiding van het rapport werden gekenmerkt door waardering voor de aanbevelingen. ${ }^{931}$ De voorzitter van het korpsbeheerdersberaad d'Hondt noemde het rapport een gedegen onderzoek. 'De commissie heeft aanbevelingen geleverd waar je wat mee zou kunnen, of je het er mee eens bent of niet.. ${ }^{932}$ Van overheidswege werd in de dagen na het uitbrengen van het rapport aangekondigd dat er stappen ondernomen zouden worden, al wilde men niet alles direct wettelijk vastleggen zoals de Commissie Van Traa woorstelde. ${ }^{933}$ Ook Naeyé en Schalken vroegen zich af in hoeverre de politie, wanneer haar geen verantwoordelijkheid wordt gelaten, dan nog de ruimte heeft haar taken professioneel uit te voeren. ${ }^{934}$ Vanuit staatsrechtelijke hoek kwam kritiek over het feit dat de Commissie Van Traa weinig aandacht in haar rapport besteed had

927. Zie ook NRC-Handelsblad, 2 december 1994, "Van Traa leidt enquête door 7 Kamerleden:.

928. Inzake Opsporing, 1996, p. 5; vgl. Naeyé/Schalken, 1996, p. 202.

929. De Volkskrant, 9 april 1996, 'Hef het Openbaar Ministerie maar op', en 12 april 1996, "Vrijbuitend OM bedreigt de democratie'.

930. Inzake Opsporing, 1996, p. 5-6, 451-453.

931. Troww, 3 februari 1996, 'Hardste oordeel blijft mild', De Wblkskramt, 3 februari 1996. 'Hele kabinet pakt chaos in opsporing aarr' en 'Parlement wacht nog zware klus ma Van Traa", Algemeen Dagblad, 3 februari 1996, "Rapport Van Traa doet pijn', Hel Parool, 5 februari 1996, 'Personele gevolgen'. Zie ook Knigge, 1996 , p. 203-204.

932. Boerstra, 1996 , p. 4.

933. Algemeen Dagblad, 3 februari 1996, 'Rapport Van Traa doet pijn' en Algemeen Dagblad, 22 februari 1996, "Kabinet walt Van Traa af"; Inzake Opsporing, 1996. p. $453-464$.

934. Naeyé/Schallken, 1996, p. 200. 
aan de zogenaamde "verticale verhoudingen in de organisatie". ${ }^{935} \mathrm{Niet}$ volstaan had mogen worden met een aanscherping van het gezag van het $O M$ ten opzichte van de politie met betrekking tot de opsporing, ook de verdergaande lijn naar minister en politiek toe had de commissie moeten behandelen. ${ }^{936}$ De Commissie Van Traa heeft weliswar voorgesteld om het gezag van het openbaar ministerile ten opzichte van de politie te wersterken, maar dat werd niet volldoende geoordeeld. 'De vraag -Quis custodiet ipsos custodes?, wie (instrueert en) bewaakt de bewakers - roept een veel scherpere beantwoording op', aldus Elzinga. 937

De behandeling in de Tweede Kamer van het rapport liet zien dat een meerderheid zich achter Commissie Van Traa stelde. ${ }^{938}$ De meeste aanbevelingen werden door de Tweede Kamer overgenomen. ${ }^{939}$ Onvrede bestond over de trage aanpak van het kabinet om actie te ondernemen tegen de verantwoordelijken. ${ }^{940}$ In september 1996 reageerden de ministers van Justitie en Binnenlandse Zaken pas op het rapport van de Commissie Van Traa door middel van een Plan van Aanpak, met als doel om orde op zaken te stellen bij politie en justitie. Het Plan bevatte beleidsuitgangspunten voor de toekomst betreffende de opsporing, echter tot onvrede van de Tweede Kamer werd er niet gesproken over maatregelen tegen degenen die verantwoordelijk geacht konden worden voor de IRT-affaire. ${ }^{941}$

935. De Wolkskrant, 24 februari 1996, 'Gezagscrisis heeft nu zelfs Van Traa bereikt', NRC Handelsblad, 2 april 1996, "Voorstellen Van Traa gaan nog niet ver genoeg" van D.J.Elzinga. Zie ook Elzinga, 1996, p. 205, 212.

936. Vgl. Elzinga, 1996, p. 212.

937. D.J. Elzinga in 'Voorstellen Van Traa gaan nog niet wer genoeg', NRC Handelsblad, 2 april 1996.

938. NRC Handelsblad, 17 april 1996, "Kamermeerderheid achter Van Traa" en 19 april 1996, 'Kamer onderschrijft $\mathbb{L R T}$-rapport, nu de maatregelen nog'.

939. Allgemeen Dagblad, 14 juni 1996, "Van Traa is tevreden na laatste debat".

940. De Wikskrant, 8 mei 1996, "Trage anpak kabinet in IRT-zaak ergert Kamer", De Volkskrant, 9 mei 1996, "IRT-debat krijgt geen personele gevolgen", NRC Handelsblad, 9 mei 1996. 'Rechtsstaat staat op het spel', Algemeen Dagblad, 10 mei 1996, "IRT-zaak krijgt gevolgen'.

941. Redactie, "Nuanceverschillen tussen Kabinet en Kamer", Algemeen Politieblad, p. 12-13. Redlactie, 'Plan van Aanpak na Van Traa', Algemeen Politieblad, 1996, p. 8-9. Trouw, 27 september 1996, 'Van Traa: Vertrouwen in politie niet hersteld', De Wolkskrant, 27 september 1996, "Van Traa kritiseert ministers vanwege nasleep IRT-affaire', Algemeen Dagblad, 27 september 1996. "Van Traa ontevreden'. 


\subsubsection{Ministeriële verantwoordelijkheid}

Naar aanleiding van de IRT-zaak wenste men in de Tweede Kamer een volledige ministeriële verantwoordelijkheid ten aanzien van het optreden van politie en justitie. Tijdens het politieke spel dat na het uitkomen van de IRTzaak ontstond, schoof de minister van Justitie deze verantwoordelijkheid af terwijl het Openbaar Ministerie deze verantwoordelijkheid juist accentueerde. ${ }^{942}$ De minister kan pas verantwoordelijk worden gehouden indien hij ook beschikt over bevoegdheden. Dit geldt ook ten aanzien van het Openbaar Ministerie. Het Openbaar Ministerie is weliswaar een bijzondere dienst. ${ }^{943}$ Het bezit een grote, overigens een niet geheel onomstreden, zelfstandigheid bij de vervolging van strafbare feiten. ${ }^{944}$ Het is echter noodzakelijk dat het Openbaar Ministerie bij het controleren van het handelen van de politie zelf ook getoetst wordt. Dat kan door de minister of door de rechter. Er waren plannen om het Openbaar Ministerie onder verantwoording van de minister van Justitie te brengen zonder het Openbaar Ministerie expliciet als dienst onder het ministerie te plaatsen. ${ }^{945}$ De commissie Donner had dit geadviseerd op 8 juni 1994 en de minister van Justitie had een reorganisatie van het Openbaar Ministerie aangekondigd in mei $1995^{946}$ Daarbij zou het Openbaar Ministerie onder leiding komen van een drie tot vijfhoofdig college wiens voorzitter benoemd wordt door de minister van Justitie. Voorlopig wordt het college gevormd door de vijf procureurs-generaal. ${ }^{947}$ Volgens Mols, De Roos en Spronken bergt dat het risico in zich dat het Openbaar Ministerie dan niet meer kritisch tegen het beleid aan kan kijken. ${ }^{948}$ Ook het Openbaar Ministerie ${ }^{949}$ zelf vreest in die situatie een

942. Elzinga, 1994, p. 529.

943. Zie ook De Wolkskrant, 8 april 1994, 'Haagse sisser'.

944. Vgl. Asscher in NRC-Handelsblad', 5 aprill 1994, "IRT-kwestie aok een gevolg van onduidelijkheid ower $O M^{\prime}$ '.

945. De Holkskram, "Hirsch Ballin wil aparte directeur voor het $O M$ ', 26 maart 1994; De Volkskrant, 8 april 1994, "Justitie vergroot toexicht op infiltratieacties'; Zie ook procureur-generaal Sorgdrager in Het Paroot, 13 april 1994. 'Het OM moet heel dicht op de politie gaan zitten'.

946. De commissie werd in december 1994 geinstalleerd, omdat er een bezorgdheid bestond over het grote aantal heenzendingen en vormfouten. Zie ook De Telegracf, 9 juni 1994, 'Organisatie OM moet op de helling'; De Wlkskrant, 9 juni 1994, "Commissie wil OM ingrijpend reorganiseren'; Trouw, 9 juni 1994, 'Een grote schoonmaak'; NRC-Handelsblad, 8 juni 1994, 'Advies: drastische hervorming justitie*. Persbericht 3232, 23/05/1995, Ministerie van Justitie, Directie Voorlichting: 'Plan van aampak gepresenteerd": Openbaar Ministerie wordt gereorganiseerd.

947. Het Parool, 23 mei 1995, 'Sorgdrager pakt OM grondig aan'.

948. Mols, De Roos en Spronken, 1994, p. 803; Vgl. Tom Schalken en Gert Jan 
aantasting van haar onafhankelijkheid. In deze visie wordt de nadruk gelegd op de magistrateli.jke rol van het Openbaar Ministerie. ${ }^{950}$ Het is hoe dan ook van belang dat de politie onder deskundige leiding wordt geplaatst en dat er controle wordit witgeoefend. ${ }^{95}$

\subsection{Het tegenwerken wan controle}

"Het Openbaar Ministerie en de rechter moeten onvoorwaardelijk kunnen vervrouwen op de juistheid en de volledigheid van het politiele proces-verbaal. ${ }^{9} \% 2$

'Te hebt te maken met nieuwe ontwikkelingen, zoals verdragen over de mensenrechten en de jurisprudentie van de Hoge Raad. Nu heb je veel meer tijd nodig woor zaken. De adwocatuur heeft fair hearing en due process ontdekt, er verschijnen meer getuigen op de zitting maar daar hangt wel een prijskartje aan in tijd. Bij de rechtbank kon je vroeger de zaken snel afdoen. Nu eist de Hoge Racad reactie op alle verweren. Bijwoorbeedd, "er is een fout in het proces-verbaal", zegr de verdachte en hij beweert dat hij geslagen is. Vroeger was het dus "niet zeuren" maar nu moet de politieman op de zitting verschijnen.

De politie kan van verschillende kanten gecontroleerd worden. Via het driehoeksoverleg wordt toezicht op het beleid gehouden. De rijksrecherche $^{954}$ controleert stratbaar gedrag van (individuele) agenten. Het parle-

948. $\rightarrow$

Lind in De Wblkskrant, 24 mei 1995, "Het onvoltooide verhaal van het Openbaar Ministerie'.

949. Bij monde van hoofdofficier Jansen uit Den Bosch, als woordvoerder van het OM.

950. Trouw, 9 juni 1994, "Otficieren vrezen "buitendienst" van Justitie te worden"; De Vilkskrant, 9 juni 1994, "Paars" omarmt aanbevelingen over aanpak OM".

951. Tom Schalken in De Vlkskkrant, 21 juni 1994, "Rechtsstaat of politiestaat". Het toppunt van controle op dit punt is wel het spreekverbod dat hoofdcommissaris. Nordholt van Amsterdam opgelegd kreeg aangaande politieke en justitiële zaken. De autonome positie van Nordholt moest beëindigd worden. Het kan betwist worden of dit de juiste manier was. Zie NRC-Handelsblad, 1 september 1994. 'Spreekverbod voor Nordholt aangevraagd". Zie ook Schalken, 1994, p. 993.

952. Nacyé, 1995, p. 24.

953. Interview met B. E.P. Myjer in Stichting Maatschappij en Politie, 1995, p. 82.

954. De taak van de rijksrecherche is 0. a. het onderzoeken van strafbare handelingen van de politie binnen het gehele overheidsapparaat. De leden van de dienst zijn bujizondere ambtenaren van politie (art. 43 Politiewet), maar ze vormen formeel geen onderdeel van de politie. Voor de politie vormt de rijksrecherche naar mijn mening voor incidentele gevallen van corruptie en ander strafbaar handelen een degelijk controleapparaat. Vanwege het geringe aantal rijksrechercheurs ( \pm 47 ) en de verdeling in wijf ressorten lijkt een grootscheepse aanpak van corruptie 
ment en de gemeenteraad kunnen vragen stellen over handelingen van de politie. Als laatste controle-instantie echter moet de rechterlijke macht niet vergeten worden. De laatste tijd wordt juist aan de rechter ${ }^{955}$ vaker gevraagd om bepaalde handelingen van de politie op hun rechtmatigheid te beoordelen. Het betreft dan meestal handelingen die in eerste instantie niet bekend waren bij de verdachte(n).

In de context van deze studie is het vertrouwen van de officier van justitie in de politie van essentieel belang. De laatste tijd is dat vertrouwen van het Openbaar Ministerie in de politie verminderd en dat is voor een belangrijk deel aan de politie zelf te wijten geweest. Steeds vaker opereert de politie in het zogenaamde politieel pro-actief wooronderzoek oftewel de informatieve voorfase ${ }^{956}$. Doordat de informatieve voorfase buiten het Wetboek van Strafvordering staat, zijn de agenten niet gehouden zich aan bepaalde regels en voorschriften te houden zoals zij dat wel moeten doen bij het toepassen van dwangmiddelen in het vooronderzoek. ${ }^{957}$ In de praktijk nemen agenten bij onderzoek in de informatieve voorfase steeds meer geheimhouding in acht. ${ }^{958}$ De geheimhouding is er enerzijds op gericht eventuele lekken binnen de politieorganisatie naar buiten tegen te gaan. Klaarblijkelijk vertrouwt de politie haar eigen leden niet. Als de politie zich zelf al niet vertrouwt, is het dan verwonderlijk dat burgers en Openbaar Ministerie dat ook niet doen? Anderzijds zorgt geheimhouding ervoor dat de buitenwereld niets te horen krijgt over de informatieve voorfase. Zelfs na de aankondiging van een parlementaire enquête naar opsporingsmethoden kwam het voor dat de politie over de hantering van bepaalde opsporingsmethodes zweeg, niet alleen tegen verdachte en rechterlijke macht maar soms zelfs ook tegen het Openbaar Ministerie. ${ }^{959}$ In dat geval naderen we echter de grenzen van de

954. $\rightarrow$

(mocht dat al bestaan) binnen het politieapparaat op dit moment miet haalbaar. Guijt, 1989, p. 383-384; Bosch, 1991, p. 84, Marchand en Wennekendonk, 1990 en 1991, p. 80; Andersson, Elffers en Felix, 1993, p. 2-3; Parren, 1989, 159.

955. Hof Amsterdam 4 februari 1993, NJ 1994, 113; HR 31 mei 1994, NJ 1995, 29; HR 26 aprill 1994, NN 1994, 736.

956. Zie ook Mols, De Roos en Spronken, 1994, p. 800, die cen voorkcur voor deze term uitspreken.

957. Mols, De Roos en Spronken, 1994, p. 801; vgl. ook NRC-handelsblad, 8 oktober 1994. 'Officier van justitie is boevenvanger geworden'.

958. Mols, De Roos en Spronken, 1994, p. 801.

959. Vorig jaar nog een zaak bij het Amsterdamse hof tegen een Utrechtse hasjsmokkelaar, waarin de politie opsporingsmethoden verzweeg. Pas in hoger beroep kwamen dexe opsporingsmethoden naar boven. De Vilkskrant, 20 mei 1995, p. 3. 
rechtsstaat en krijgen te maken met organisaties die zich boven de wet willen stellen.

\subsection{Ontbreken wan controle}

Terwijl de IRT-affaire duidelijk heeft gemaakt dat het toezicht op de politie door het Openbaar Ministerie duidelijk verbetering behoeft, zien we bij de reorganisatie juist het gevaar ontstaan dat van bestuurlijke kant (burgemeesters en gemeenteraden) de controlefunctie zou kunnen gaan verminderen.

Cachet heeft op het gevaar gewezen dat de politie in de regio een eigen leven kan gaan leiden. Het heeft namelijk geen ... "normaal" politiek-bestuurlijk niveau'. ${ }^{960}$ Daarmee bedoelt hij aan te geven dat de politieregio geen eigen regional bestuur heeft. Het bestuur over de regio (het regionaal college) is samengesteld uit verschillende gemeentebesturen en burgemeesters die ieder voor hun eigen gemeente bepaalde belangen hebben. Als de samenwerking hiertussen niet vlekkeloos verloopt, kan de politie vrij zelfstandig haar eigen beleid ontwikkelen en uitwoeren. ${ }^{961}$ Dit is echter iets wat door de regering juist niet beoogd wordt. Ook de Raad van State wees er in zijn advies inzake de nieuwe Politiewet 1993 op dat een korps zelfstandig moet kurnen functioneren maar dat een degelijk beheer door een instantie buiten de politie een verzelfstandiging van de politie voorkomt ${ }^{962}$ Tot de invoering bestond het beheer uit één persoon, de burgemeester of de minister. Dat is nu anders. De individuele belangen van de burgemeesters in het regionaal college zouden de samenwerking kunnen belemmeren. ledere burgemeester moet immers tegenover zijn gemeenteraad verantwoording afleggen over hetgeen besloten is in het regional college. Het gemeenschappelijk belang (een politie die duidelijke sturing ontvangt) zou het dan afleggen tegenover de individuele wensen van de verschillende gemeenten. Of dit tot een effectief beheer over een regiokorps zal leiden is nog maar de vraag. Voorgesteld is om uit het regional college een dagelijks bestuur te formeren dat nauw kontakt kan onderhouden met korpsbeheerder en officier

960. Cachet, 1991, p. 12.

961. Volgens het onderzoek van het Crisis Onderzoek Team maken burgemeesters, afficieren van justitie en gemeenteraadsleden zich hierower geen zorgen. Men wertrouwt op de consensus-cultur in Nederland 1994, p. 213. Het is de vraag in hoeverte die wens de vader is van de gedachte. De Telegraaf, 1 juni 1994, 'Te weinig sturing en controle van politie'. Zie ook Cachet, Van Sluis, Van der Torre, Rosenthal en Muller, 1993, p. 45-46.

962. TK, 1991-1992, 22562, B, p. 2. In Duitsland bestaat een dergelijk model. De Polizei-president is een hoge burger-ambtenaar. Hier komen de twee aspecten van Wilson, bureaucratisering en professionalisering, naar voren. Vgl. Van Reenen, 1993, p. 15-16. 
van justitie. 93 De Memorie van Toelichting laat er geen misverstand over bestaan dat de schalvergroting niet mag leiden tot een grotere verzelfstandiging van de politie en een grotere afstand tussen politie en burgerij. ${ }^{964}$ Vanuit politiek-bestuurlijk oogpunt moet juist de politie gestuurd en gecontroleerd worden. ${ }^{95}$

\subsection{Afsluitende opmerkingen}

Het eerste grote Nederlandse schandaal na de Tweede Wereldoorlog heeft ervoor gezorgd dat er een structureel overleg tussen politiecommissaris, (hoofd-) officier van justitie en burgemeester ontstond. Het IRT-schandaal heeft tot nu toe ertoe geleid dat een parlementaire enquêtecommissie een onderzoek heeft gedaan naar de opsporingsmethoden van de politie en de controle erop. ${ }^{966}$ De aanbevelingen van de commissie die geformuleerd zijn in haar rapport zijn door Tweede Kamer en kabinet goed ontvangen, echter nog niet daadwerkelijk in voorstellen ongezet. ${ }^{967}$ Dit laatste schandaal heeft duidelijk gemaakt dat de politie nadrukkelijker onder controle moet komen, zowel van het Openbaar Ministerie als van de politiek.

De gebeurtenis in Amsterdam in 1966 heeft geleid tot een hervorming: het driehoeksoverleg. Aan het driehoeksoverleg is veel waarde gehecht en het belang van het overleg werd algemeen aanvaard. Het driehoeksoverleg is tegenwoordig zelfs op operationeel niveau werkzaam. Sommige IRT's hebben zelfs een eigen driehoeksoverleg. Recent onderzoek heeft echter aangetoond dat het overleg helaas niet meer zo optimaal functioneert als verwacht werd. De politie ontwangt lang niet altijd de verwachte sturing en het beleid wordt ook niet altijd voldoende gecoördineerd. Desalniettemin ben ik van oordeel dat de hervorming die voortvloeide uit de rellen van 1966 omschrewen kan worden als een redelijk succeswolle hervorming, zeker in de jaren 80.968

De IRT-zaak kan met recht een schandaal genoemd worden. Nooit eerdet" werd in Nederland een dergelijke ophef over politieoptreden gemaakt. Dit

963. Zie bijw. Redactioneel. "Verzelfstandiging van de politie", Tijdschrift woor de Politie, 1993, nr, 10, p. 289.

964. TK, 1991-1992, 22562, nr. 3, p. 4.

965. Crisis Onderzoek Team, 1994, p. 1.

966. Inzake Opsporing, 1996, p. 11.

967. Met uitzondering van het Plan van Aanpak van de ministers van Justitie en Binnenlandse Zaken varn september 1996.

968. Van Outrive, 1981, p. 88: Het bijkt er wel op dat de politie - of juister de politiechefs - krachtens dat driehoeksowerleg nog het meest aan macht inboeten en hun "verzel.fstandiging" goed wordt ingeblikt." 
schandaal zou een goede aanleiding zijn nader te onderzoeken wat er nu mis is in en rond het politieapparaat. Het instellen van een parlementaire enquêtecommissie is een cerste goede aanzet geweest om het politieoptreden nader te onderzoeken. Jammer is het dat de opdracht van de commissie beperkt is gebleven tot de opsporingsmethoden en de controle over de opsporingsmethoden. Op dit moment is het onmogelijk te zeggen of tengewolge van het IRT-schandaal nieuwe regel- of wetgeving (een hervorming) zal volgen die meer zal zijn dan een "kruistocht". Tot nu toe ${ }^{969}$ lijkt het die kant niet op te gaan.

969. Januari 1997. 


\section{Slotbeschouwing}

\subsection{Inleiding}

In deze studie ging mijn belangstelling vooral uit naar de vraag of de onafhankelijkheid van de politieorganisatie en de onmogelijkheid tot het uitoefenen van controle gevolgen had voor begrippen als vertrouwen in de politieorganisatie en legitimiteit van het optreden van de politie. Het feit dat in Engeland en Wales de politiekorpsen formeel onafhankelijk zijn en er geen externe onderzoeks- of controle-instanties zijn zou een extra reden moeten zijn voor een daadwerkelijk beheersing van het politieapparaat. De beschreven schandalen boden mij daarvoor een goed aanknopingspunt. Ze stelden mij in staat om te bekijken hoe van overheidswege gereageerd werd op een schandaal waarbij de politie in een kwaad daglicht werd gesteld. Het doel hiervan was om na te gaan of de reacties van de overheid dermate effectief waren dat de legitimiteit wan het politieoptreden en het vertrouwen van de burgers in de politie terugkeerden.

De vraag 'Wie bewaakt de bewakers?" 970 geeft aan dat men niet elke politieagent op zijn woord moet geloven. Controle is juist in dit geval essentieel omdat aan deze 'bewakers' grote macht is toegekend. De vraag "Wie bewaakt de bewakers?' is verder van belang omdat politieagenten, als ordehandhavers, zich niet alleen zoals andere burgers aan de wet moeten houden, maar zij bovendien geacht worden boven elke verdenking te staan. Dit laatste veronderstelt dat het politieoptreden een legitieme basis heeft en dat de politieorganisatie een open, doorzichtige ${ }^{971}$ organisatie is, die openstaat voor controle, intern of extern ${ }^{972}$. Voor de politieorganisatie zou er in feite derhalve geen (groot) verschil mogen bestaan tussen het 'mythe-systeem' (het geheel van regels en normen binnen een samenleving waaraan iedereen geacht wordt zich te houden) en de wijze waarop de politie zich in de praktijk gedraagt (de operationele code) ${ }^{973}$ Bestaat er wel een verschil dat door een schandaal bekend wordt, dan zal de overheid via een reform trachten het 'mythe-systeem' te herstellen of het gedrag van de politie bij te stellen.

970. Who controls the controllers? of Quis custodiet ipsos custodes?

971. Met dit begrip bedoel ik hier dat de organisatie niets te verbergen heeft. Voor rechtszaken betekent dit concreet dat er volledige openheid wordt gegeven wan en in dossiers.

972. Intern: het opmaken van dagstaten en processen-verbaal. Extern: een dienst die een onafhankelijk onderzoek uitvoert en waarvan dat door velen erkend wordt, zoals de Algemene Rekenkamer in Nederland.

973. In de praktijk bestaat er alijd een verschil tussen mythe en operationele code. 
In de praktijk komt een verschil tussen het 'mythe-systeem" en de operationele code voor wat betreft het optreden van de politie. Dit verschil is enigszins verklaarbaar doordat de politie moet werken onder druk om smel resultaten te behalen, omdat de toe te passen regels ruimte laten voor 'illegaal' optreden en omdat er een gebrek aan controle bestaat. Door de operationele code kan de politie autonomie voor zich verwerven. ${ }^{974}$ In mijn studie heb ik daar voorbeelden van genoemd. De politie kan bewust de regels omzeilen (zoals we gezien hebben in de IRA-zaken); het systeem accepteert of heeft niet de mogelijkheid om te verhinderen dat regels niet wolledig nageleefd worden (rellen van 1966); en een combinatie van die twee is ook mogelijk (IRT: een samenzwering om regels te omzeilen die mogelijk was door zwakheden in het systeem).

In het woorgaande heb ik voor alle schandalen de reactie beschreven op de aanval op het 'mythe-systeem', om te bekijken of we iets kunnen leren hoe organisaties omgaan met de gevolgen van schandalen. Daarbij stond in deze studie niet centraal de vraag hoe we ervoor kunnen zorgen dat afwijkend gedrag binnen het politieapparaat tot het verleden gaat behoren of hoe dit afwijkend gedrag ontstond. Dan zou ik onderzocht hebben hoe de operationele code ontstaan zou zijn. In dat geval zou ik op het terrein van de organisatie- of de industriële sociologie komen en zou ik tevens de micro-processen van de gecompliceerde organisatie als de politie bekeken hebben. Op dit terrein ben ik echter geen deskundige en ik heb het derhalve bewust buiten beschouwing gelaten.

Verder heb ik bekeken of de aanwezigheid wan controle-instanties een voldoende waarborg biedt ter voorkoming van problemen. Op al deze onderwerpen wil ik in dit slothoofdstuk nog even terugblikken.

\subsection{Engeland en Wales}

\subsubsection{De onafhankelijkheid}

De 43 politiekorpsen in Engeland en Wales zijn onafhankelijk. Deze onafhankelijkheid past bij de (politieke, juridische en culturele) achtergrond van de Britten. Eeuwenlang hebben de Britten een grote indiwiduele vrijheid gehad. ${ }^{975}$ Tot ver in de 20 ste eeuw was het contact met de overheid ge-

974. Zowel in Engeland en Wales en in Nederland.

975. Vgl. Pringle: "In die tijd was Brittannië het enige land in Europa zonder een officiële beroepspolitiemacht - en daar zeer trots op bovendien. Onze voorouders gingen er prat op tat dit een bewijs was voor hun liefde voor vrijheid. In feite was het slechts een bewijs van hun tegenzin in veranderingen.' 1957, p. 10. 
ring. Reizen zonder paspoort was voor de Engelsman een vanzelfsprekende aangelegenheid. ${ }^{976}$ Onder andere tengevolge van ernstige rellen aan het einde van de 18de, begin 19de eeuw, die slechts met behulp van het leger bedwongen konden worden, werd door de Britse regering besloten degelijke politiekorpsen op te zetten. De staat mocht echter niet teveel macht hebben, want daarmee zou de individuele vrijheid van de burgers aangetast worden. Wanneer de staat zeggenschap zou krijgen over de politie - zoals naar Frans model - dan zou de staat een te grote macht verwerven. Dat moest voorkomen worden. De politie diende los te staan van de overheid. Bij de oprichting van de Britse politie in 1829 is de onafhankelijkheid van de politie als argument gebruikt om te voorkomen dat de overheid de politie als middel zou gebruiken om bepaalde politieke doelen te bereiken. ${ }^{977}$

Ondanks de onafhankelijkheid staat de moderne politie in Engeland en Wales toch bloot aan invloeden van de centrale overheid, het Europese Hof voor de Rechten van de Mens en de media. Van alle kanten wordt er getrokken aan de politie. De politie in Engeland en Wales heeft daarbij te maken met een diversiteit van doelstellingen die vaak elkaars tegenpolen ${ }^{978}$ zijn zoals het krachtig bestrijden van de georganiseerde criminaliteit tegenover bezuinigingen en het materiaal leveren voor een fair tria $l^{79}$. De politie is niet in die positie dat ze geen rekening hoeft te houden met de wensen van politiek, media en rechtspraak. Zou de politie er namelijk geen rekening mee houden, dan zijn van deze drie kanten repercussies, te verwachten. De overheid kan dreigen met het dichtdraaien van de financiële kraan of met wetgeving. De media zouden negatief kunnen berichten over de politie waardoor de maatschappij het vertrouwen in de politie (nog meer) verliest. De rechterlijke macht zou zaken kunnen laten stuklopen op het niet voldoen aan een fair trial vanwege het politie-optreden.

De politie is dus niet zo onafhankelijk als gesuggereerd wordt. ${ }^{980}$ Indirecte beïnvloeding en indirecte macht van (voornamelijk) de overheid is steeds aanwezig. De politie zal deze inbreuk op haar onafhankelijkheid niet gauw

976. Taylor, 1970, p. 25-26.

977. Bijvoorbeeld als spion, zoals wel het geval was in Frankrijk.

978. Ik bedoel hier niet de ordehandhavende en dienstwerlenende taak versus de strafvorderlijke taak.

979. Bijvoorbeeld het wettelijk verplicht zijn on alle bewijsmateriaal atan de verdediging te onthullen.

980. Naast de bestuurlijke onafhankelijkheid, kennen we ook de operationele onafhankelijkheid. Bestuurlijke afhankelijkheid verwijst naar het op een formele wijze afleggen van verantwoording wanneer daar om gevraagd wordt. De operationele onafhankelijkheid leidt er echter toe dat problemen informeel opgelost worden. Alles wordt binnen de organisatie gehouden. 
aan de buiterwereld toegeven omdat dat zou kunnen leiden tot een nog grotere aantasting van de onafhankelijke positie van de politie.

\subsubsection{Scandal and reform}

\subsubsection{Schandalen}

Onafhankelijkheid (zonder controle) kan neigen naar misbruik van macht. Misbruik van macht behoort in dit verband niet te eng worden opgewat. Daaronder kan van alles begrepen worden: van individuelle misstappen van agenten tot gebrek aan leiding door hoofdcommissarissen. De vijf Engelse casus die ik besproken heb, zijn daar voorbeelden van. Het ging steeds om mistoestanden die waren uitgegroeid tot schandalen, die leidden tot gevolgen op nationaal niveau.

\subsubsection{Het traject van de zes P's}

De vijf voorbeelden uit Engeland en Wales hebben een reactie van media en overheid tot gevolg gehad. Het verloop van probleem tot uiteindelijke reactie heb ik "het traject van de zes $\mathrm{P}^{3}$ ' ${ }^{981}$ genoemd. Dit traject ligt in het verlengde van de theorie van Lawrence W. Sherman in zijn Scandal and reform. In zijn studie had Sherman aangetoond dat in veel gevallen van politiecorruptie een schandaal nodig was om daar verandering in teweeg te brengen en om die corruptie - meestal tijdelijk - uit te bannen.

Schema: de zes P's

\section{Problem$$
\downarrow
$$ \\ Publicity \\ $\downarrow$ \\ People \\ $\downarrow$ \\ Politics \\ $\downarrow$ \\ Policy \\ $\downarrow$ \\ Practices}

Een crisis of potentieel schandaal wordt gesignaleerd.

De media maken keuzes, besteden aandacht aan en brengen het schandaal naar buiten.

Woord voerders (moral entrepeneurs) reageren op het schandaal.

De overheid treedt op tegen het schandaal. Het schandaal kan niet langer genegeerd worden. Er wordt nieuw beleid of nieuwe wetgeving gemaakt.

In de praktijk moet blijken of beleid en/of wetgeving helpen.

981. Zie hoofdstuk 10. 
In dit schema is in trefwoorden de volgorde te zien van de gang van zaken bij crises en schandalen. Allereerst is er een incident dat door de media ${ }^{2} 2$ al dan niet naar buiten wordt gebracht. Er ontstaat bij de bevolking verontwaardiging hetgeen aanleiding is voor de politiek om een nieuw beleid uit te stippelen. Dit beleid wordt vervolgens in de praktijk getoetst. Het is geen natuurlijk proces, want de loop van het schandaal is afhankelijk van de keuzes die gemaakt worden en de middelen die voorhanden zijn. Niet elk potentieel schandaal heeft derhalve dit vergaande resultaat.

\subsubsection{Hervormingen}

De overheid zit in een moeilijke positie wanneer een politieschandaal uitgebreid in de media aan bod komt. Er zal iets moeten gebeuren. Tussen de schakeis politics en policy uit het woorgaande schema wordt er druk overlegd en advies ingewonnen bij allerlei instellingen om de juiste reactie te geven. Wordt het schandaal serieus behandeld en past de voorgenomen wijziging in het beleidsplaatje van de regering (reform) of wordt voor de schijn iets ondernomen omdat een echte wijziging van het beleid in strijd met het bezuinigingsplan zou zijn (crusade)? M.a.w. hoe belangrijk wordt het geacht om het vertrouwen in het systeem terug te winnen? Daarna is de vraag aan de orde hoe kritisch de media de ideeẻn van de regering zullen beoordelen. Wanneer het nieuwe beleid door de media negatief beoordeeld wordt, zal het probleem opnieuw uitgebreid in de publiciteit gebracht worden. Men is weer terug bij af (problem en publicity). In dat geval wordt de vicieuze cirkel pas doorbroken wanneer de media en belangengroepen 'tevreden' zijn met de voorgestelde oplossing van de regering.

Bij de casus die in deze studie besproken zijn was de belangrijkste vraag of de uiteindelijke beleidsverandering wel geleid heeft tot een structurele oplossing. Uit de afzonderlijke hoofdstukken kwam naar voren dat dat in geen van de gevallen echt bereikt is. Aan de ene kant wordt er wel naar het probleem gekeken en een oplossing gezocht. Aan de andere kant zorgen de factoren tijd, mensen en politiek ervoor dat uiteindelijk de problemen onvoldoende grondig worden opgelost, omdat de onafhankelijkheid butten schot blijft. Daardoor worden er vaak oppervlakkige veranderingen aangebracht die weliswaar enkele verbeteringen inhouden, maar geen radicale verandering tot gevolg hebben. Schandalen geven aan dat er diepliggende problemen zijn, maar het duurt jaren om de maatregelen die genomen zijn te evalueren. Tegen die tijd is de maatschappij of het systeem weer veranderd en verschijnen er weer nieuwe schandalen. Geen enkele hervorming lijkt

982. De rol van de pers moet niet onderschat worden. De pers kan zowel positief (het aan het daglicht brengen van een probleem) als negatief (de aandacht vestigen op andere zaken dan de hoofdzaak, zoals in de IRT-affaire) werken. 
echt de dieperliggende problemen van het verzwijgen van informatie, loyaliteit jegens collega's in plaats van jegens het gezag, afwijkend gedrag en onafhankelijkheid aangepakt te hebben.

\subsubsection{Controle}

'It's very important the police are kept in check by sociery. There are those who would otherwise abuse their power. ${ }^{983}$

Zonder formele gestructureerde controle-instanties kunnen agenten steeds weer vervallen tot het misbruik maken van hun bevoegdheden. Dit misbruik kan uitgroeien tot een probleem wanneer het onderdeel van de politiecultuur wordt. Interne controle blijkt onwoldoende te zijn. De controle door de lokale politiecommissie kan theoretisch een rol spelen maar is door jurisprudentie en de praktijk ${ }^{984}$ monddood gemaakt. De jurisprudentie stelt onomwonden dat de verhouding politie-politiecommissie niet zodanig opgevat mag worden dat de politie een dienaar is van de commissie. ${ }^{985}$ In de praktijk kiest het Home Office bij conflicten tussen hoofdcommissarissen en politiecommissies openlijk de kant van de hoofdcommissaris. ${ }^{986}$ Rechterlijke controle is wel mogelijk maar kan pas na tussenkomst van vaak dezelfde politile ingeschakeld worden. De centrale overheid heeft door het inzetten van inspecteurs van het Home Inspectorate een afzonderlijk middel in handen om de korpsen te controleren op hun doelmatigheid. Echter, alleen de organisatie en de procedurele wijze van wetshandhaving maken deel uit van het onderzoek van de inspecteurs. Bij geconstateerde tekortkomingen kan de centrale overheid besluiten de jaarlijkse financiële bijdrage te verminderen. In de praktijk is dit middel bij éën politiekorps in de jaren ' 80 ge-

983. Rose, 1996, p. 224-225.

984. Zie de verschillende interviews in de bijlagen. "They (i.e. de politie) have quite a lot of resources to entertain the authority (i.e politiecommissie), as a free lunch, flying in the police helicopter and then suddenly there is no serious questhoning of their activities.' Mullin.

985. Fisher v. Oldham Corporation (1930) 2 K.B. 364, Attorney-General for New South Wales v. Perpetual Trustee Co Ltd (1955) A.C. 457.

986. Zie hoofdstuk 5. Ook beschikt de politie over mogelijkheden om de politiecommissie aan haar kant te krijgen. Zie het interview met Chris Mullin (bijlage). 
bruikt. ${ }^{987}$ Een externe controledienst in Engeland en Wales die deviant gedrag binnen de politieorganisatie onderzoekt ontbreekt.

Mijn interviews die opgenomen zijn in de bijlage laten drie alternatieven zien, waar men zelf aan denkt. Men pleit voor betere lokale controle ${ }^{988}$, voor een permanente onafhankelijke herzieningscommissie ${ }^{989}$, die vermeende miscarriages of justice zou moeten gaan bekijken en voor het instellen van een soort rechter-commissaris ${ }^{90}$. Op deze wijze zou zowel de professionele/juridische controle als de politieke controle verbeterd kunnen worden.

\subsection{Nederland}

\subsubsection{Zelfstandigheid}

In Nederland heeft men van oudsher gekozen voor een politie, die bevelem moet opvolgen en die ter verantwoording geroepen kan worden. Net als elders op het vasteland was men bang voor een te machtig politieapparaat. ${ }^{991}$ Daarom kunnen zowel op lokaal als op centraal niveau politiehandelingen aan de kaak worden gesteld.

De 25 regiokorpsen in Nederland zijn verantwoording schuldig aan enerzijds de korpsbeheerder voor ordehandhavende taken en anderzijds de officier van justitie voor de strafrechtelijke handhaving van de rechtsorde. De politie is niet formeel onafhankelijk. In het driehoeksoverleg, waarin officier van justitie, burgemeester en korpschef deel hebben, wordt het politiebeleid op elkaar afgestemd. Op centraal niveau kunnen parlementsleden politieproblemen in de Tweede Kamer aan de orde stellen. Daarnaast bestaat in Nederland de rijksrecherche, een onafhankelijke instantie die bij strafbare hande-

987. Derbyshire Constabulary ontving $51 \%$ van haar jaarlijkse toelage van de centrale overheid. De lokale overheid wilde echter dat Londen meer zou betalen en weigerde derhalve uit protest de toellage met de resterende $49 \%$ aan te vullen. De toestanden waaronder de agenten in Derbyshire moesten werken werden zo slecht dat het korps, ondanks de inzet van de individuele agenten, niet goed meer kon functioneren. Als gevolg daarvan ontwing het korps geen certificale of efficiency waardoor als sanctie de overheid weer minder geld beschikbaar stelde. Berry, Izat, Mawby, Walley, 1995, p. 60.

988. Mullin en Mansfield zijn deze mening toegedaan

989. Logan.

990. Dit is een idee van Michael Mansfield, die daarbij de Franse juge d'instruction voor ogen heeft gelvad.

991. Een gedeelde verantwoordelijkheid van de ministers van Binnenlandse Zaken en Justitie is daar ook een voorbeeld van. 
lingen van ambtenaren een onderzoek instelt. De rijksrecherche staat garant voor een objectief onderzoek.

Ondanks dat er twee structurele mechanismen in het systeem zijn die het streven naar onafhankelijkheid van de politie tegenhouden en eventueel strafbaar gedrag van agenten kunnen onderzoeken, kent Nederland ook enkele politieschandalen, die te maken hadden met onafhankelijk optreden van politieagenten. In mijn studie heb ik er twee besproken. Deze twee gebeurtenissen lieten zien dat ook de Nederlandse politie, ondanks het feit dat de politie verantwoording moet afleggen, toch die verantwoording kan omzeilen. De discretionaire bevoegdheid van agenten kan ook hier ontsporen. Zoals de politiekorpsen in Engeland en Wales eigenlijk niet geheel onafhankelijk zijn, is de Nederlandse politie juist in haar optreden wel eens onafhankelijk.

\subsubsection{Scandal and reform}

\subsubsection{Schandalen}

Bij de rellen in Amsterdam uit 1966 was een verslechterde verhouding tussen de politie en de burgemeester oorzaak woor het kunnen ontstaan van de problemen. Er was ook een slecht contact tussen politieambtenaren onderling. Het betrof mensen die niet met elkaar wilden of konden samenwerken. Bij de wellen in Amsterdam kreeg de politie te weinig algemene richtlijnen en veranderde het beleid snel. Hierdoor ontstond de situatie dat individuele politieambtenaren zelf oncontroleerbare beslissingen namen. In de IRT-zaak van 1994 waren het Interregionaal rechercheteam en de CID in staat voor zichzelf controle op een afstand te houden en derhalve een zekere mate van onafhankelijkheid te creëren. Het interne controlemechanisme, d.w.z. de directe leiding binnen het politiekorps, had gefaald om toezicht te houden op het IRT. Op beleidsniveau functioneerde het driehoeksoverleg niet optimaal.

\subsubsection{Hervormingen}

De rellen in Amsterdam hebben geleid tot het landelijk invoeren van driehoeksoverleg-structuren. In dit overleg zouden de burgemeester en de officier van justitie de leiding hebben en het politiebeleid op elkaar afstemmen. Hierdoor vergrootte de controle over de politie wezenlijk, zowel formeel als informeel. Mede als gevolg van de IRT-affaire is een parlementaire enquêtecommissie onder leiding van Van Traa benoemd. De commissie heeft op 1 februari 1996 gerapporteerd over de opsporingsmethoden van de politie. Daarbij heeft de commissie alleen aanbevelingen gedaan over het controle- 
ren van de politie tijdens de opsporing. ${ }^{922}$ Over politieke controle wordit weinig gezegd. Behalve de introductie van het Plan van Aanpak zijn er op het niveau van de politieorganisatie geen andere matregellen genomen.

Nederland kent dit decennium één grote politiehervorming waar geen dringende noodzaak aan werbonden was. De Politiewet 1993 lijkt, alhoewel er lange tijd over gesproken en gedebatteerd is, zonder een duidelijk aanwijsbare oorzaak- bijvoorbeeld een schandaal - tot stand te zijn gekomen. Er is geen fel ideologisch debat gevoerd over de zin of het nut wan de politie(reorganisatie). Nederland was volgens de politiek wel toe aan een reorganisatie. De drijfveren voor een nieuwe politie waren de administrative rationality $^{993}$ en de internationale consistentie. Daarnaast was er de wens voor een bestuurlijke vernieuwing. Is dat echter voldoende voor een reorganisatie? Is het bijvoorbeeld zo dat grotere korpsen beter opgewassen zijn tegen de stijgende lokale en internationale criminaliteit? Uit mijn studie valt af te leiden dat deze vragen niet direct bevestigend zijn te beantwoorden. In sommige gevallen zal de efficiëntie zeker verbeteren maar of daarmee ook de effectiviteit verbetert, is maar zeer de vraag. Van Reenen is daar zeer sceptisch over. ${ }^{9 / 4}$ Een verandering zonder een duidelijke reden of doelstelling zal niet veel oplossen of verhelpen, laat staan één-twee-drie de críminaliteit verminderen. A reform without a scandal is no reform. Een verandering is pas succeswol als daar een degelijke reden aan ten grondslag ligt, die aansluit op herkenbare problemen. Maar ook is een verandering pas een succes als het een echte hervorming is en geen crusade.

\subsubsection{Controle}

Nederland kent ondanks de aanwezigheid van controlerende instanties problemen met het optreden van de politie, waarbij de politie gehandeld heeft in strijd met regels of beleid en warvoor zij geen verantwoording heeft afgelegd. Uit de twee casus die ik besproken heb, bleek dat de controle die theoretisch aanwezig moet zijn, er feitelijk niet of onvoldoende was. De reden daarvoor was o.a. de verslechterde verhouding tussen politie, justitie en burgemeester. De aanwezigheid van controlerende instanties sec is der-

992. Het rapport van Van Traa, Inzake Opsporing, heb ik maar ten dele bestudeerd. Commissie Van Traa wilde al het pro-actieve optreden van de politie reguleren. Maar dat leek de regering iets te ver te gaan. De politie(k) wil meer speelruimte hebben. Hoe dit afloopt kan ik hier niet melden.

993. Grotere korpsen maken die sterker staan tegenower de misdaadsyndicaten. Men wilde af van dualisme, kleine korpsen, en 'kJeine' burgemeesters, die zich alleen interesseerden in hun politie en problemen in hun dorp/stad.

994. Van Reenen, 1993. 
halve niet steeds voldoende voor thet garanderen van correct en probleemloos optreden van de politie.

Ik ben deze studie begonnen met de stelling dat een onafhankelijke politie niet woor te stellen is zonder problemen. Aan het begin van de studie ging ik nog uit van het idee dat een politie die verantwoordelijk is jegens de lokale en/of de centrale overheid een voldoende garantie biedt tegen politiemisbruik. Concluderend moet ik nu stellen dat dat niet steeds het geval hoeft te zijn. Ook Nederland heeft problemen, terwijl hier de politie theoretisch nog steeds veel minder onafhankelijk is.

Externe controle alleen is gezien de twee Nederlandse casus niet de enige garantie tegen misbruik. De verhoudingen tussen de verschillende mensen bij politie en controle-instanties spelen een grote rol bij het voorkomen van misbruik. Het falen van de controle lijkt dus naast andere - hier niet behandelde - complexe organisatieprocessen, een oorzaak te hebben in menselijke verhoudingen, die immers van negatieve invloed kunnen zijn op het adequaat functioneren van controle-instanties. ${ }^{995}$

\subsection{Conclusie}

\subsubsection{Engeland en Wales}

De vijf voorbeelden in Engeland en Wales die ik hier behandeld heb, tonen mijns inziens atan dat het ontbreken van adequat controlerende instanties tot grote misstanden kan leiden. Had in al deze gevallen iemand of een instantie toezicht gehouden op de politie of had de politie geweten dat haar gedrag onderworpen zou worden aan controle, dan is het waarschijnlijk dat het lang niet zo ver gekomen zou zijn in deze besproken gevallen.

In Engeland en Wales zijn de schandalen steeds aangegrepen om - uiteindelijk en soms na jaren - wetswijzigingen in te voeren. Schandalen hebben daar geleid tot een verandering van het systeem. Dit is in overeenstemming met de theorie van Sherman: Scandal and reform. Het politieke systeem is echter niet altijd even gewillig om daadwerkelijk te veranderen. Met andere woorden, soms kan het lijken dat een bepaalde wetswijziging de oplossing is ter voorkoming van een soort schandalen, maar is er eigenlijk alleen het imago van overheid en politie opgevijzeld, ergo een crusade en geen echte herworming zoals Reisman zou zeggen.

Ondanks de vijf grote schandalen lijkt de politie tot nu toe in staat te zijn haar onafhankelijkheid te behouden. De schandalen hebben er nog niet toe

995. Dit geldt natuurlijk zowel voor Engeland en Wales als Nederland. 
geleid dat er een efficiënte externe controle is. De wetswijzigingen die woortgekomen zijn uit de schandalen hebben daarnaast het vertrouwen van de burgers in de politie niet doen toenemen. In zijn bijdrage aan de Royal Commission on Criminal Justice verwordde Mullin het verband tussen vertrowwen en controle aldus: 'There is not the slightest hope of successfully overhauling our criminal justice system without a dramatic change in the culture of our police, particularly in the elite detective squads. If public confidence is to be restored there will have to be a thorough review of police recruitment, training and disciplinary procedure and the introduction of a genuinely independent complaints procedure. ${ }^{996}$

In Engeland heeft men bij het laatste grote schandaal beseft dat het hele strafrechtsysteem gefaald heeft. Dat kan men zien aan het feit dat de Royal Commission on Criminal Justice een zeer uitgebreide taakomschrijving meekreeg. Men besefte dat de geloofwardigheid van het systeem aangetast was. Als gevolg daarvan werden er maatregeien genomen. Een van die maatregelen was de eis van disclosure die inhoudt dat de politie verplicht is openheid van zaken te geven. Zoals we gezien hebben worden er nu bij de politie zogenaamde "standards' gesteld waardoor het politiegedrag op sommige terreinen openlijker en het concept van 'policing by consent' weer dichter genaderd wordt. Met name is die tendens te zien bij de public servi$c e$-taak. We hebben echter gezien dat deze taak voor het publiek de minste problemen oplevert. Dit werk wordt juist grotendeels gewaardeerd. Toch zal deze maatregel het imago van de politie verbeteren en het publiek versterken in het idee dat de politie er voor de Britse bevolking is, terwijl feitelijk de wetshandhavende taak waar de meeste problemen gesignaleerd worden tussen politie en burger, niet verbeterd wordt.

Het meest opmerkelijke van het rapport van de Royal Commission on Criminal Justice is dat niet wordt stilgestaan bij de onafhankelijkheid van de politie. Mocht ook de regering dit niet doen, dan kan dit naar mijn meming ertoe leiden dat de oorzaak van het probleem niet weggenomen wordt en dan kan men voorspellen dat de onafhankelijkheid wederom oorzaak van nieuwe schandalen wordt.

We moeten niet uit het oog verliezen dat de Britse achtergrond en cultuur een controlesysteem naar continentaal model in de weg staan. ${ }^{997}$ De onafhankellijkheid van de politie lijkt niet te combineren te zijn met vergaande controlemogelijkheden. De controle die op dit moment bestaat is niet afdoende. De positie van het Police Complaints Authority in het bestel is zeer

996. Mullin, Evidence to the Royal Commission on Criminal Justice, November 1991, (ongepubliceerd), $\$ 25$.

997. Het conservatisme en het geloof in het eigen politieapparaat blijven overheersen. 
zwak. 'The PCA is a complete waste of time as any honest member of the PCA will tell you privately. It is one of the least effective institutions that exist. ${ }^{988}$ Bovendien zal zolang de politie in Engeland en Wales zichzelf onderzoekt, bij de burgers niet het vertrouwen aanwezig zijn dat die onderzoeken deugdelijk en diep uitgevoerd worden. De woorstellen die hierboven genoemd zijn, zoals de irwoering van meer lokale controle ${ }^{999}$, van een onafhankelijke herzieningscommissie en van een rechter-commissaris, zouden evenwel kunnen bijdragen tot een politie die door een brede maatschappelijke laag vertrouwd wordt. Daarnaast zou gedacht kunnen worden aan de invoering van een rijksrecherche naar Nederlands model.

\subsubsection{Nederland}

Achteraf gezien kunnen de rellen in Amsterdam in 1966 en het driehoeksoverleg dat daaruit woortgekomen is, beschouwd worden als een trendbreuk. De noodzaak voor bestuurlijke controle werd ingezien en verwezenlijkt. Voor het eerst kwam er ook een groot schandaal naar buiten. Tot die tijd werden problemen in de doofpot gestopt en het aftreden van ministers was nog niet aan de orde.

In de dertig jaar na de rellen van Amsterdam is er veel veranderd. De rol van de media is drastisch gewijzigd, vooral die van de televisie. De misdaadjournalistiek, maar ook de onderzoeksjournalistiek, is gegroeid. In de media wordt meer nadruk gelegd op 'affaires' en schandalen. De roep om het aftreden van verantwoordelijke personen wordt geëist. Het onderscheid met de Angelsaksische pers zal niet veel langer bestaan. Deze tijd wordt ook gekenmerkt door de verschillende enquêtecommissies ${ }^{1000}$. Veel meer wordt tegenwoordig grondig onderzocht, mede dankzij de grote aandacht van de media. In navolging van hetgeen in Engeland en Wales speelt zullen de media trachten meer invloed te krijgen op het politie- en ander overheidsoptreden. Dat kan zowel voor- als nadelig zijn. Het voordeel is dat verkeerd overheidsoptreden op grote schaal aan de kaak gesteld wordt waardoor herhaling deels woorkomen kan worden. De media fungeren dan als controle-instanties. Daarnaast kunnen media kleine incidenten ten onrechte tot schandaal maken en op die manier de onvrede over de politie en de onrustgevoelens bij de politie overbodig opkloppen. Dan controleren de media niet meer, naar maken misbruik wan de situatie.

De IRT-affaire liet zien dat men geleidelijk de aandacht van Amsterdam (door de Commissie Wierenga) verplaatst heeft naar het grotere gebied van

998. Zie interview met C. Mullin.

999. Of juist verkleining van de organisatie-eenheden.

1000. RSV, Bonwsubsidies, Paspoort. 
opsporingsmethoden waarin zowel politie, Openbaar Ministerie en ministers betrokken worden (Commissie Van Traa). We zouden kunnen stellen dat 1996 een potentiële trendbreuk vormt. Het strafproces verkeert in een crisis. ${ }^{1001}$ Tijdens het functioneren van het $I R T$ leek de politie alles te mogen. Het vertrouwen van goed geïnformeerde burgers in de politie is gering geworden. Het is de vraag in hoeverre de overheid bereid is om hierin verandering te brengen.

De ontwikkelingen tot nu toe na het bekendworden van het IRT-schandaal laten een afwachtende houding zien. Het IRT-schandaal is een uitstekende gelegenheid om het systeem te hervormen op die punten waar het mis is gegaan en die gelegenheid zou met beide handen gegrepen moeten worden. Maar toch lijkt dit niet te gebeuren en dat is jammer. Het lijkt alsof het systeem de burgers en zichzelf geruststelt. De minister van Justitie wil nog niet overgaan tot het ontslaan van mensen. De aanbevelingen van de Conmissie Van Traa werden waardevol geacht, maar zijn bij lange na nog niet door de regering overgenomen. De wettelijke veranderingen die voorgesteld zijn hebben slechts een beperkte reikwijdte. Op een of andere manier lijkt in Nederland een bewustzijn van het falen van het systeem niet echt aanwezig bij media, publiek, politiek en politieorganisatie. Terwijl het IRT-schandaal in eerste instantie ging over de vraag wie nu de verantwoordelijke minister in deze was, spitste de zaak zich pas na enkele maanden toe op de vraag hoe het zover had kunnen komen. Toen uiteindelijk een parlementaire enquêtecommissie in het leven werd geroepen, was de opdracht een onderzoek in te stellen naar de gebruikte opsporingsmethoden. Men kan zich afvragen waarom de regering de opdracht voor de parlementaire enquêtecommissie beperkt heeft tot opsporingsmethoden, terwijl het zo duidelijk voor de hand lag te concluderen dat ook de controlemechanismen niet goed gefunctioneerd hebben? Zou het niet beter zijn geweest wanneer een Nederlandse Royal Commission ${ }^{1002}$ eens een diepgaand onderzoek naar ons ge-

1001. Van Traa constateerde drie elementen in de crisis:

- normeringscrisis: d.w.z. dat er geen adequate normstelling is voor het optreden van de politie tegen de georganiseerde misdaad;

- organisatiecrisis: teveel organisaties en te weinig coördinatie;

- gezagscrisis: het gezag over de opsporing staat ter discussie.

Van Traa, Inzake Opsporing, 1996, p. 419-420.

1002. Ondanks de mogelijkheid om parlementaire enquêtecommissies te benoemen en staatscommissies te installeren kent Nederland geen equivalent woor een Royal Commission. Een commissie die adviseert aan de regering en waarvan de leden afkomstig zijn uit rechterijike macht, adwocatuur, Openbaar Ministerie, politie, politiek en wetenschap, geeft aan de ene kant wel een adwies dat voornamelijk uilt compromissen voortgekomen is, maar bestrijkt wel alle mogelijke facetten van het onderzoeksgebied 
hele strafprocesrecht had gedaan? Op dit moment lijkt het erop dat de voorgestelde herwormingen na de IRT-affaire het stempel 'kruistocht' zullen krijgen. Alleen de tijd zal ons dit echter leren.

In Nederland heeft middels de nieuwe Politiewe 1993 een politiereorganisatie plaatsgevonden zonder dat een schandaal eraan woorafging. De reorganisatie is daarentegen voorafgegaan door een politiek debat dat enkele decennia geduurd heeft. ${ }^{1003}$ De reorganisatie is derhalve een woorbeeld van een administratieve, politieke hervorming. Kan een dergelijke reorganisatie waarin hoofdzakelijk de structuur van de organisatie maar niet de personen of de aard van het werk veranderd zijn, daadwerkelijk gevolgen hebben voor efficièntie en effectiviteit? In het voorgalande zijn bij deze vraag vraagtekens gezet. Naar aanleiding van de reorganisatie verscheen er op 31 mei 1994 een rapport 'Politiebestell in verandering: Verhoudingen tussen politie, bestuur, justitie en gemeenteraad onder de oude en de nieuwe Politiewet" van het Crisis Onderzoek Team. Het Crisis Onderzoek Team twijfelde aan de deskundigheid wan officier van justitie, gemeenteraadsleden en burgemeesters om om te gaan met de nieuwe regionale politie. Eén van de conclusies uit het rapport was dat de politie vanwege te weinig sturing van officier van justitie en burgemeester mogelijk alleen kwam te staan. Daardoor zou de politie in een positie gebracht worden dat ze zonder begeleiding of overleg bepaalde beslissingen zou moeten nemen. De politie zou dus meer macht kunnen krijgen hetgeen in het rapport niet als een positieve ontwikkeling werd beschouwd. ${ }^{1004}$ Terwijl dus in de jaren '60 de noodzaak voor bestuurlijke controle ingezien werd, lijkt de recente reorganisatie uit 1993 - ongewild - juist te leiden tot afstand van bestuurlijke controle.

Het is belangrijk dat de controle-instanties zelf gecontroleerd worden. Daarmee bedoel ik dat wij moeten oppassen voor een onafhankelijke politie vanwege het mogelijke misbruik dat zou kunnen ontstaan. Het bestaan van een rijksrecherche, die Engeland en Wales ontberen, kan incidentele corruptiegevallen onderzoeken maar de rijkstecherche is niet zo" $n$ grote dienst dat ze de corruptie als fenomeen kan aanpakken en kan ook geen ingebedde democratische controle vervangen. Deze onafhankelijke instantie onderzoekt in verhouding te weinig zaken om structureel iets te kunnen bereiken. Een degelijke democratische controle is van belang, omdat het de organisatie doorzichtiger maakt. Door de komst van de regionale korpsen en een over

1003. Terwijl politie en justitie nog volop bezig waren met het verwerken van de gevolgen van de reorganisatie, ontstond de IRT-affaire. De vraag zou gesteld kunnen worden of de IRT-affaire er wel geweest zou zijn wanneer er geen reorganisatie had plaatsgevonden.

1004. Crisis Onderzoek Team, 1994, p. 211-228. 
het algemeen in verhouding zwak regionaal college lijkt deze controle het kind van de rekening te zijin geworden.

\subsection{Ten slotte}

'Teveel politiemensen zijn in het nauw gedreven - dat heeft geleid' tot onjuiste processen-verbaal, anonieme informatie, tipgevers, inkijkoperaties, enz. De solidariteit onderling is ook gevaarlijk. Het is dodelijk als bij wijze wan spreken, meer dan $I$ op de 1000 processen-verbanal wolstrekt wervalst is. "hous

In deze studie heb ik laten zien dat in navolging van de theorie van Sherman schandalen nodig zijn en gevolgd worden door hervormingen, i.c. mieuwe wetten en andere regelgeving. ${ }^{1006}$ Deze nieuwe wetten werden en worden in Engeland en Wales zeer belangrijk geacht maar hebben er niet direct toe geleid dat de politie een meer verantwoordelijke en transparante organisatie werd die onder effectief publiek toezicht is komen te staan. Want niet zozeer de onafhankelijkheid van de politie in Engeland en Wales is het probleem, maar het gebrek aan verantwoording. Het vertrouwen van de burgers in de organisatie nam niet toe en de legitimiteit van het politieoptreden is eveneens niet toegenomen. Het controleprobleem werd met andere woorden niet opgelost. Dit heeft een dieper liggende oorzaak.

De politieorganisatie wordt gekenmerkt door conservatisme, d.w.z. men wil niet gauw overgaan tot veranderingen en men wil het bestaande het liefst zo lang mogelijk in stand houden. De discretionaire bevoegdheid, het zonder toezicht van superieuren kunnen handelen, het binnen het korps voor elkaar opkomen en het bewijs een handje helpen, zijn allemaal elementen die bijdragen tot een - in meer of mindere mate - cultuur waarin politiegeweld, intimidatie en onrechtmatig verkregen bewijs goedgepraat wordt. '... (W) hem you believe in the guilt of the defendents you can justify to yourself making up a few things to fill in some gaps in the case against them. "Toot Tegen

1005. Uit interview met J.C.M. Leijten in Stichting Maatschappij en Politie, 1995, p. 25 .

1006. Kan nieuwe en gedetailleerde wetgeving een bijdrage leveren tot het voorkomen van verkeerd handelen van de politie? Het is naief te denken dat dat zo zou zijn. Het bestaan van een wetboek van strafrecht heeft er rot nu toe nog niet toe geleid dat strafrechters werkloos worden. Ook een politiereglement zal niet kunnen voorkomen dat er zo nu en dan buiten het boekje gehandeld wordt. De aampak van een dergelijk probleem zal op een andere wijze moeten geschieden. Naast preventieve manieren zou gedacht kunnen worden aan meer repressieve controle, dit is controle achteraf door rijksrecherche of democratische controle door lokale of nationale overheid. Gardiner voegde daar nog aan toe controle door belangengroeperingen en burgetorganisaties. Gardiner, 1970 .

1007. Zie interview met $C$. Mullin. 
deze achtergrond ligt het ook voor de hand dat een onafhankelijke politie niet gauw geneigd zal zijn haar onafhankelijkheid prijs te geven. De politie is niet afkerig van controle zolang de controle door de eigen organisatie geschiedt. Veel verder lijkt de politie niet te willen gaan.

Bij alle schandalen, zowel de Nederlandse als de Engelse, die ik in deze studie besproken heb, was zowel de onafhankelijkheid, openheid en verantwoordelijkheid een probleem als de verhouding tussen de burgers en de politie en tussen de top van de politie en de lagere rangen. Agenten in uniform, in speciale diensten en in burger waren in staat controle te omzeilen en zowel hun meerderen als de rechters te laten geloven dat hun handelen volgens de regels was. De conclusie van dit alles moet zijn dat nieuwe structurele en culturele veranderingen en controlemechanismen van essentieel belang zijn om een einde te maken aan deze ongewenste situatie. De maatschappij verlangt en verdient een verantwoordelijke maar ook een open politieapparaat dat optreedt in het algemeen belang met goedvinden van diezelfde maatschappij. Nieuwe regels en wetgeving kunnen maar deels voor een oplossing zorgen. Het belang van het naleven van regels en wetten moet opnieuw door de top van het politieapparaat geleidelijk door middel van beleid duidelijk gemaakt worden aan de agenten. Dit geldt ook voor integriteit en het openstaan voor externe controle. Justice not only needs to be done but it also has to be seen to be done. Dit betekent een culturele aampassing in de politieorganisatie. Ook de controleurs moeten gecontroleerd worden maar dan moeten ze daar wel voor openstaan, anders is die controle niet effectief. ${ }^{10018}$

1008. En dan zou met recht gesteld kunnen worden dat de uitspraak van Sir Robert Mark op pagina 1 van deze studie niet langer een mythe is, maar werkelijkheid is geworden: 'The fact that the British police are answerable to the law, that we act on behalf of the community and not under the manile of government, makes us the least powerful, the most accountable and therefore the most acceptable police in the world.' Maar of het ooit zover zal komen ...? Zie ook het interview met A. Logan: "Amybody who has power must be accountable." 


\section{Samenvatting}

In deze studie staat de onafhankelijkheid van de 43 politiekorpsen in Engeland en Wales centraal. De onafhankelijkheid dateert vanaf de introductie van de politie in Engeland en Wales in 1829. De onafhankelijkheid van de politie in Engeland en Wales heeft tot gevolg dat de politie niet ter verantwoording kan worden geroepen door de lokale en de centrale overheid. Ook zijn de hoofdcommissarissen van de politiekorpsen niet verplicht bevelen of richtlijnen van bijwoorbeeld de minister van het Home Office (Binnenlandse Zaken) op te volgen. Een officier van justitie met gezagsbevoegdheden over de politie zoals in Nederland, kennen Engeland en Wales niet. Vanuit Europees oogpunt is deze onafhankelijkheid uniek en de moeite waard nader te bekijken.

Een van de vragen die rijzen is of de politie, vanwege het feit dat controle nagenoeg ontbreekt, misbruik makkt of kan maken van de bevoegdheden die door de wet aan de politie zijn toegekend. In hoeverre wordt de onafhankelijkheid van de politie door de burgers in Engeland en Wales nog als legitiem ervaren? In deze studie wordt nagegaan of de onafhankelijkheid gevolgen heeft voor het vertrouwen van de burgers in de politie en voor de legitimiteit van het politieoptreden. Kan er ondanks de onafhankelijkheid nog sprake zijn van policing by consent?

Deze probleemstelling wordt uitgewerkt aan de hand van gebeurtenissen uit de laatste 40 jaar die bij de burgers in Engeland en Wales tot onvrede en verontwaardiging hebben geleid over het politieoptreden. Het zijn gebeurtenissen die uitgegroeid zijn tot schandalen en die telkens geleid hebben tot een verder politiek onderzoek. Een vijftal type schandalen wordt in deze studie besproken: causes célèbres (de jaren '50-'60), de dood van Blair Peach (de jaren "70), de rellen in Brixton, de Confait-zaak (beide de jaren '80) en de miscarriages of justice (de jaren " $80-' 90$ ), waaronder de IRAzaken begrepen worden.

De vijf beschreven schandalen hebben gemeen dat de regering in Londen zich in alle gevallen gedwongen voelde ofwel een onderzoekscommissie ofwel een Royal Commission in te stellen naar de oorzaak of achtergronden van het probleem. Deze commissies hebben in rapporten de achterliggende problemen geanalyseerd en aanbevelingen aan de regering gedaan. In alle gevallen heeft dit vervolgens geleid tot wetswijzigingen en beleidsveranderingen. Deze gang van zaken komt overeen met hetgeen beschreven is in de theorie van de Amerikaan L.W. Sherman warvan in 1978 een boek gepubliceerd werd met als titel Scandal and Reform. Sherman beweerde in zijn boek dat in veel gevallen van politiecorruptie een schandaal vereist was om een verandering in of een hervorming van de politieorganisatie te bewerk- 
stelligen. De politie blijkt mamelijk een organisatie te zijn die bijna afkerig is van veranderingen. De politie is zeer conservatief.

Het verloop wan de schandalen die in dit boek beschreven zijn, laat telkens een bepaald traject zien. In de studie wordt dit het traject van de zes P's genoemd: problem, publicity, people, politics, policy en practices. Volgens dit traject wordt eerst een crisis of een potentieel schandaal ontdekt. Dit wordt bekendgemaakt aan de media, die er al dan niet ruchtbaarheid aan geven. Moral entrepeneurs benadrukken de ernst wan de situatie en wakkeren de verontwaardiging bij het publiek aan. De poilitiek wordt gedwongen op het schandatal te reageren met beleid of wetgeving. In de jaren na de introductie van nieuw beleid of wetgeving kan pas blijken of er afdoende gereageerd is op het schandaal.

Aan het einde van de studie komt de Nederlandse situatie aan de orde. Vanwege twee redenen wordt dit gedaan. Allereerst laat ik daarmee zien dat in tegenstelling tot hetgeen in Engeland en Wales steeds het geval is, verandering van politiewetgeving ook zonder schandaal tot stand kan komen: de reorganisatie van de politie in Nederland in 1994. Daarbij vraag ik me af in hoeverre het zinvol is iets te wijzigen zonder dat aangetoond is dat het bestaande systeem gebreken of tekortkomingen vertoont: $A$ reform without a scandal is no reform. Volgens Reisman (Folded Lies) is het pas na verloop van enkele jaren mogelijk om te bekijken of een hervorming of verandering van het systeem daadwerkelijk tot de gewenste doelen geleid heeft. Sherman stelt in ieder geval dat een schandaal de meeste legitimitent biedt voor aanpassing of verandering.

Naast de bespreking van de reorganisatie van de Nederlandse politie, worden twee Nederlandse schandalen (de rellen in Amsterdam en de IRT-affaire) behandeld die laten zien dat ook bij een politie die niet onafhankelijk genoemd kan worden en die ter verantwoording geroepen kan worden controle een probleem blijft.

De conclusie van de studie luidt dat het ontbreken van adequaat controlerende instanties grote misstanden tot gevolg kan hebben en ook daadwerkelijk heeft gehad in de afgelopen 40 jaar. De misstanden hebben er echter niet toe geleid dat de politie in Engeland en Wales een meer verantwoordelijke en transparante organisatie werd die onder effectief publiek toezicht is komen te staan. De politie is niet genegen om haar onafhankelijkheid af te staan en de politiek is niet bereid om aan die onafhankelijkheid te tornen. De weg lijkt derhalve nog open voor een nieuw schandaal. Ondanks de schandalen van de afgelopen jaren is de algemene indruk die de burgers in Engeland en Walles van de politie hebben niet bijzonder negatief. De zin 'every country in the world envies us our police' wordt ook nu nog in Engeland en Wales gehoord. Het vertrouwen van de burgers in de politie en de 
legitimiteit van het politieoptreden wordt echter wel aangetast door telkens terugkerende of nieuwe schandalen.

De maatschappij verdient een verantwoorstelijke maar ook een open politieapparaat dat optreedt in het algemeen belang met goedvinden van diezelfde maatschappij: policing by consent. Nieuwe regels en wetten kunnen maar deels voor een oplossing zorgen. Het belang van het naleven van wetten en regels moet opnieuw door de top van het apparaat door middel van beleid of instructies duidelijk worden gemaakt aan de agenten. Dit betekent een culturele aanpassing in de politieorganisatie, die geleidelijk verwezenlijkt kan worden. Ook de controleurs moeten gecontroleerd worden maar dan moeten ze daar wel voor openstaan, anders is die controle niet effectief. 


\section{Summary}

In this study the independence of the 43 police forces in England and Wales is at issue. The independence dates from the establishment of the police in England and Wales in 1829. The consequence of this independence is that the police cannot be called to account by the local authorities or the government. In line with this the chief constables of the police forces are not obliged to take orders or directions from, for example, the Home Secretary. A public prosecutor with authoritative power over the police which is the case in the Netherlands, is unknown in England and Wales. From a European point of view this independence is unique and thus worth further inspection.

One of the questions that arises is whether the police, due to the fact that supervision is virtually absent, abuses or can abuse the power granted them by law. To what extent do the citizens of England and Wales regard the independence of the police as legitimate? This study examines whether this independence affects the trust civilians put in the police and the legitimacy of police action. In spite of the independence can we still speak of policing by consent?

These issues are examined with the help of a description of events over the past 40 years which, among the citizens of England and Wales, have led to dissatisfaction with and indignation at police action. They are events which have developed into scandals and each has led to further political investigation. Five types of scandals are dealt with in this study: causes célèbres (in the fifties and sixties), the death of Blair Peach (the seventies), the Brixton riots and the Confait case (both in the eighties) and the miscarriages of justice (the eighties and nineties) by which the IRA cases are meant.

These five scandals have in common that in each case the government in London felt compelled to institute either a committee of inquiry or a Royal Commission in order to investigate the cause or background of the problem. They analysed the underlying problems and advised Parliament. All cases resulted in amendments of law and changes in policy. This procedure corresponds to the theory by the American L.W. Sherman, whose book 'Scandal and Reform' was published in 1978. In his book Sherman claims that in many cases of police corruption a scandal has been necessary to bring about change in or reform of police organisation because the police are very conservative and averse to change.

In each case the development of the scandals described in my book follows a particular course which I call the course of the six P's: Problem, Publicity, People, Politics, Policy and Practices. Accordingly, first a crisis or potential scandal is discovered. Then the press are informed and the case 
may or may not be made public. Moral entrepeneurs emphasize the gravity of the situation and stir up the indignation of the public. Parliament is forced to respond to the scandal by policy making or legislation. In the course of the years following the introduction of a new policy or law it becomes apparent whether or not the scandal has been dealt with efficiently.

Finally I discussed the Dutch situation. I have two reasons for this. First and foremost the Dutch situation is in contrast with that in England and Wales and is proof of change in police legislation being possible without the incentive of a scandal: the reorganisation of the police in 1994. I have, however, questioned whether it is advisable to change something without having proven that the existing system is in any way deficient. According to Reisman (Folded Lies) it takes several years before one can judge if a reform or change has actually led to the desired results. At least a scandal offers the highest form of legitimacy for adjustment or change.

Besides the reorganisation of the Dutch police I have also discussed two Dutch scandals (the riots in Amsterdam and the IRT affair). These scandals show that even when the police is not independent and therefor can be called to account supervision remains a problem.

The conclusion of my study is that lack of adequate supervisory bodies can result in abuse and this has happened over the past 40 years. However, in England and Wales this abuse has not led to a more accountable and transparent police organisation with effective public supervision. The police is not prepared to surrender its independence and politicians are not willing to go back on this independence. So the channels are open to a new scandal. Despite the scandals of the past years the English and Welsh citizens, in generall, do not have a particularly negative impression of the police. "Every country in the world envies us our police'. This is a pronouncement still heard in England and Wales. However, the public's trust in the police and in the legitimacy of police action has been affected by recurring or new scandals.

Each society deserves a police force which is accountable and open and which operates in the public interest by consent of that same society: policing by consent. New rules and laws can only partly create a solution. The top of the police force must reassert the importance of laws and rules to the constables by means of policy and instruction. This entails a cultural adjustment within police organisation which can be realized gradually. Supervisors must be supervised as well but for this to be effective they should be open to supervision.

Anita Romano 


\section{Resumen}

Den e estudio aki e posishon independiente di e 43 cuerponan policial di Inglatera y Wales ta para central. E independencia aki ta existi desde e fundashon di polis na Inglatera y Wales na 1829. E posishon independiente di e polis di Inglatera y Wales tin como consequencia cu polis no por a ser yamá dor di autoridatnan local y central pa duna cuenta. Tampoko e alto comisarionan di e cuerponan policial tabata obligá di sigui ordennan of directivanan di por ehempel e ministro di e "Home Office' (Asuntonan Interno). Un fiscal cu autoridat riba polis manera na Hulanda, no ta existi na Inglatera y Wales. Di punto di bista Europeo e independencia aki ta unico y ta bale la pena analis'é di serca.

Un di e preguntanan cu ta surgi ta si polis, pa motibo cu casi no tin control, ta abusá of por abusá di e competencianan cu a ser otorgá pa ley na polis. Te den ki grado e cuidadanonan di Inglatera y Wales ainda ta sinti e posishon independiente di polis como legitimo? Den e estudio aki ta averigua si e independencia tin consequencianan pa e confiansa di e cuidadanonan den polis y pa e legitimidat p'e actuashon policial. No obstante e independencia ainda por papia di "policing by consent"?

E asuntonan aki ta wordo discuti a base di un describshon di e eventonan den a ultimo 40 añanan, cu a causa desgusto y indignashon serca e cuidadanonan di Inglatera y Wales relashoná cu actuashon policial. Ta trata di eventonan cu a desaroyá den escandalonan y cu cada biaha a resultá den un investigashon politico mas aleu. Un cinco tipo di escandalo ta wordo discuti den estudio aki: causes célèbres (añanan '50-'60), e fallecimento di Blair Peach (añanan '70), e disturbionan na Brixton, e caso Confait, (ambos na añanan ' 80 ) y e miscarriages of justice (añanan ' 80 -'90), entre cual e casonan di IRA.

E cinco escandalonan describí tín den comun cu e gobierno di London a hanja su mes obligä den tur e casonan pa instală sea un comishon di investigashon sea un 'Royal Commission' pa investigá e causa of e trastondo di e problema. E comishonnan aki a hasi un analysis den rapportnan di e problemanan cu a hiba na esaki y a hasi recomendashonnan na gobierno. Consequentemente tur e casonan esaki a resultá den cambionan di ley y di maneho. E procedura aki ta cuadra cu lokual ta ser describí den e teoria di e Americano L.W. Sherman di cual na 1978 un buki a ser publica cu e titulo Scandal and Reform. Sherman ta elaborá den su buki bisando cu den hopi caso unda tin corupshon policial, a tuma un escandalo pa realisá un cambio den of un reformashon di e organisashon policial. Polis ta mustra di ta un organisashon cu ta sinti avershon pa cu cambionan. Polis ta masha conservativo. 
E desaroyo di e escandalonan cu ta describí den mi buki, semper ta mustra un cierto trajecto. Mi ta yama esaki e trajecto di e seis P-nan: problem, publicity, people, politics, policy y practices. Segun e trajecto aki na prome lugá un crisis of un escandảlo potensial ta wordo descubrí. Esaki ta ser divulgá na e medionan di comunicacion, cu sea lo publicá esaki of no. Entrepeneurs di moral ta emfatisá e seriedad di e situashon i ta lanta indigashon serca e publico. Politica ta wordo obligá pa reacshoná ariba e escandalo formulando un maneho of introduciendo legalislashon. Den e añanan despues di e introducshon di maneho nobo of legislashon lo sali na kla si a reacshoná adequado riba e escandalo.

Na final cli mi estudio mi ta discuti e situashon Hulandes. P'esaki tin dos motibo. Na promé lugar mi ta demostrá cu esci, cu contrali na locual semper bai ta e caso na Ingletera y Wales, na Hulanda cambio di legislashon encuanto polis tambe ta posibel sin escandalo: Manera e reorganisashon di polis na 1994. Den esey mi ta puntra mi mes te na unda tin sentido pa cambia algo sin cu a keda demonstrá cu e sistema existente ta contene fayonan. Segun Reisman (Folded Lies) ta solamente despues di algun aña ta posibel pa ripará si un cambio di e sistema en berdad hiba na logra e matanan deseá. Sherman ta bisa en todo caso cu un escandalo ta duna un legitimidad mayor pa hasi adaptashonnan of cambionan.

Ademas di discuti e reorganisashon di polis Hulandes, dos escandalo Hulandes (e disturbionan na Amsterdam y e IRT-affaire) ta wordo tratá. E escandalonan aki ta demonstrá cu tambe cu un polis cu no por ser yamá independiente y cu por wordo yamá pa duna cuenta, e aspecto di control ta keda un problema.

E conclushon di e estudio ta cu e falta di instancianan cu ta controlá na un manera adequado por causa problemanan grandi y cu durante e ultimo 40 aña esaki tabata realmente e resultado. E problemanan aki sinembargo no a conducí na un situashon caminda polis na Inglatera y Wales a bira un organisashon mas responsabel y transparante cu a bin cai bou di un supervishon efectivo publico. Polis no ta mucho dispuesto pa laga su posishon independiente kai y politica pa mishi cu e posishon independiente ei. No obstante e escandalonan di e ultimo añanan, e impreshon general cu e cuidadanonan di Inglatera y Wales tin di polis no ta particularmente mucho negativo. E frase 'every country in the world envies us for our police' awendia ainda por ser scuchá na Inglatera y Wales. E confiansa di e cuidadanonan den polis y e legitimidad di actuashon policial sí ta wordo manchá pa e escandalonan cu sea cada biaha ta surgi di nobo of ta nobo.

E comunidad ta merece un aparato di polis responsabel, pero tambe transparante cu ta actua na interes general cu aprobashon di e mesun comunidad ey: policing by consent. Reglanan y leynan nobo solamente por percura 
parcialmente pa un solushon. E importancia di cumpli cu leynan y reglanan mester wordo splicá di nobo na e agentenan di polis dor di e alto mando di e cuerpo di polis, haciendo uso di maneho y istrucshon bon cla. Esaki ta inserấ un adaptashon cultural den e organisashon policial, cu por wordo realisá gradualmente. Tambe e controladornan mester wordo controlá, pero nan mester ta accessible pa esaki, sino e control no ta efectivo.

R.T.J.M. Oomen 


\section{Bijlagen}

1. Overzicht van de verschillende commissies in Engeland en Wales.

\begin{tabular}{|c|c|c|c|c|}
\hline Titel Commissie & Jaartal & Taak commissie & Aanleiding & Gevolg \\
\hline $\begin{array}{l}\text { Royal Com- } \\
\text { mission on the } \\
\text { Police }\end{array}$ & 1960 & $\begin{array}{l}\text { Kijken naar de con- } \\
\text { stimutionele positie } \\
\text { van de politie in het } \\
\text { licht van de afwezig- } \\
\text { heid van politieke } \\
\text { verantwoordelijk- } \\
\text { heid. }\end{array}$ & $\begin{array}{l}\text { Incidenten in de } \\
\text { jaren vijftig die } \\
\text { een slechte ver- } \\
\text { houding tussen } \\
\text { politie en burger } \\
\text { lieten zien }\end{array}$ & Police Act 1964 \\
\hline
\end{tabular}

1) Inofficiële onderzoekscommissie

2) Scarman

1) Scarman

2) Royall Commission on Criminal Procedure (Commissie Philips)
1) 1981 1) Onderzoek naar

2) 1981 de oorzaak wan het overlijden van dhr. Peach.

2) Onderzoek naar de oorzaak van de Brixton-rellen.
1) 1981 1) Onderzoek naar
2) 1981 de oorzaak van de Brixton-rellen.
2) Enerzijds: de politiebevoegdheden inzake opsporing, anderzijds: de rechten en plichten van verdachten.

1) Commissie

Fisher;

2) Royal Commission on

Criminal Procedure

Royal Commission on Criminal Justice (Commissie Runciman)

1) 1975 1) Onderzoek naar

2) 1981 het schenden van de rechten van drie jongeren door de politie.

2) Zie boven. miscarriages of
De dood van een De klachten. onderwijzer procedure in de tijdens een de- Police and Crimonstratie door minal Evidence mishandeling Act 1984 door de politie

Rellen in de wijk Police and CriBrixton in Lon- minal Exidence den Act 1984

De veroordeling Prosecutions of

Offences Act van drie jongeren de moord op dhr. Confait.

1993 Voorstellen te doen Vermietiging van tot wijziging wan het uitspraken in de strafrechtsysteem in zogenaamde IRAhet licht van de zaken. justice. 


\section{Regeringen in Engeland en Wales sinds 1940.}

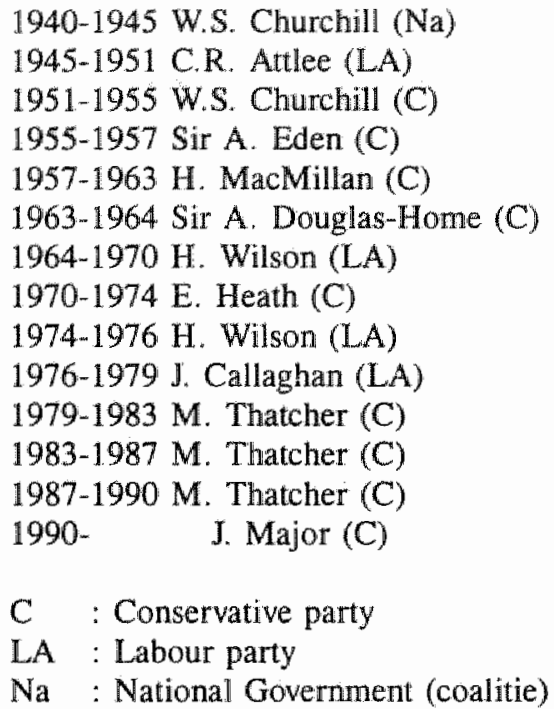

\section{Interviews}

De interviews die hieronder volgen zijn op band opgenomen en later op papier gesteld. Spreektaal is echter bij lange na geen schrijftaal. Intonatie en benadrukking in de spreektaal zijn, zonder toegevoegde tekens of woorden, op schrift niet zichtbaar. Wat tijdens het interview vaak duidelijk was door de manier van spreken, is later op schrift soms onduidelijk. Desalniettemin denk ik dat de interviews voor zich spreken.

Interview met Michaed Mansfield QC. in Londen op 13 mei 1993.

Michael Mansfield is een barrister (advocaat/procureur) en heeft o.a. in hoger beroep de verdachten verdedigd in de zaken Judith Ward, Tottenham Three, Birmingham Six, Cardiff Three ${ }^{1009}$ en de Orgreave Miners. Hij is tevens schrijver van het boek Presumed Guilty, 1993.

CR: ll know you are a barrister and you have been acting in the Bimingham Six case and the Carduff Three calse.

MM: On appeal.

CR: What especially was remarkable in these cases, concening the police?

MM: I suppose the main fearure in the Cardiff case, which is the most recent, and in my view the most significant and telling of the miscarriage-cases, - athough it has not had the same exposure as 
the other cases - is this, that everybody suld about the normal miscarriage-cases, that everybody knows about, "Oh that occured 20 years ago and it could never happen again. Certainly. we are in a better and a stronger position now. Therefore everybody can relax a bit, and not gee foo worried. All these cases, as the Birmingtham Six, Maguine Sewen, Guildoro Four, are all olld cases."

Carditif Three demonstrated that that is nonsense, because in happened und ar we curremey of the PACE ACt ${ }^{\text {sio }}$ which was supposed to protect individuals beng interrogated and to protect some civill rights, although not very many.

I personally never saw PACE as a protection. The Cardif Thee demonstrated that it isn't, because not only it was operating under the PACE there was also a tape-recorder runnug throwgh the buter wew and thene was also a solicitor present during all the interwiews save wo (there were 19).

The mosi striking about that case was, that the police knew that they were being witnessed by a tapereconder and a solicitor, but newertheless they practiced oppressive questioning of an extreme kind. So one can only imagine, that when they don"t have a tape-recorder and when there isn't a solicitor present, it is twice as bad as it was in the case. As it was, it was enough. The Lord Chief Justice, wnce he heard some of the lapemeconding stopped the appeal at that point and allowied the appeal on the point of the tape recording.

Basically what the police did in that case and what the police have bean doing for yeats and years is the presumption of guilt which is why l have called the book Presumed Guily. Becalsse, contrary to the principle that everyone is presumed to be innocent, they make grotesque sssumptions that they are above eweryone who is guilhy. Sometimes there is a bit of evidence to get behind it, sometimes there isn't.

In the Cardiff Three case, the only evidence they had after ten months of inwestigation aganst the person 1 represented, called Miller, was one statement from one witness who was a woman-pucostitute, a colleague of the dead woman-prostinte. She had told a multitude of lies, during the police investigation until she finally came ap with a version of events, whereby she claimed that she wemt in tor the premises where the dead woman was and saw Miller standing in the premises near the body. That was the only evidence they had. Just ther word. There was no scientific link between him and the premises: no palmprints, no fingerprints, no blood. And the evidence they did have, tended to suggest somebody else than Miller was responsible. So it was based on a very slender thread of what this woman was claining, a woman who was later discredited in terms of credibility in tral. There was no credibility. The police constructed the case around her word. Her massive allegation against Miller was suggested during an interview without really letting him know that was all they had.

But, they got to the truth. They knew the truth, there was no way out. 'You are going having to sit thene till you came up with the truth. Why would these people be saying all this about you?' They bad other techniques. The soft approach, the hard approach "undermining his confidence, suggesting his alibi was firlse suggesting people said things, which they hadn"t and so on. Misleading him.

The solicitor didn"t intervene early on this. The technique they finally used was to suggest that as he was somebody who lived on the streets he might occasionally take drugs. And if he took drags and drink ard if he would take thern on the night penthaps he wowd not have known where he was and if he did not know where he was maybe he was in the flat where it all look place. So they lod hilm showly bu surely, because hu denied any involwentent ower 300 lines. Finally when he reallased they wyere not going to except his denials, he obviodisly decided he would have go go along with what they were alling him and they were giving him a lot of detais what they wanted him to sidy. After a period of time he agreed with evefything they said and they thought that was it. And dhey closed the book. Overnight another woman-prostirute came along and gave another warsion of what happened. Which wasnit quite the sante as the one they had been working on. So they started all ower again. They went back to Miller. 'Well actually, what you lold as isn't the truth after all. The real tnuth is what we have now been told.' And they started the process all ower again. I haventh told you and the thing they possibly did not know but shoud have known. was that Miller, like the one in the Tohtenham Three-case, was a young man of a mental age of about eleven and a reading age of nine. And althougli his comversation was quite articulate and flowing, he was disadvantaged. Sol a highty suggestible, ill -ducated. low 10 -person finds himself confronted by police officers who bully him and make it feel as though he is never going to get out anyway and a for of people have prat thim in a dell so he might as well admit to it, has led to an horrific adinission: he admited o wo something that 
led whis conviction and if that hasnit beer rectifed he woudd still be inside now. Despite all of that, and the fact is that his own words are tape-recorded - and I have got the tapes - I go around to meetings and play the tapes. People are horrified. People do not want to hear, canti believe it.

It just epitomizes everything thit has gone wrong. police still believe that the short circut to rue pollice work is an admission. I saves them having to track arownd the streets. It closes books, in clostes files; hatisfies communithes. The public feel mabe they have got the right person and they can all go home to bed. The confession is the easiest way.

And that hat been compounded over the yeats by the Einglish court regarding a confession as the bes: kind of evidence. They tended to think that a confession reguired no kind of corraboration. So the Cardiff case in my wiew is really the epitomy where everything has gone wrong.

The Birmingham case also epitomizes things that have gone wrong. There it is more complicated. And in al sense more serious. Horrific: So people wanted people to be convicted and there was an owerwhelming belief that once the police had got these Six that was it. The door closed on them. They were undoubtedly beaten up in custody. Nobody has ever dispulled that although nobody thas ever been convicted for committing the assauit on them.

I suppose the tho aspects of that case that are significant, one of which didnt happen in the Cardiff case, was that the scientific tests that were used to swab the men in the first place were highly suspect, and were krown at the time not to be conclusive tests. But the evidence which tended to indicate that they weren't conclusive tests, was mot put before the court. And now is the question of disclosure. There wasn't disclosure of all of the material facts that related to the tests at the time and in fact during the first appeal and the second appeal that material was not disclosed. It wasn't disclosed until the final appeal that this test had been used on the same night on other people. That they had been positive but they were released, because the test wasn't conclusive of nitroglycerine or high explosives. And it was only later that the scientist conducting this test has been discredited in the final appeal and meanwhile he had been retired for "limited efficiency". That is the phrase that has been used. So the nature of the scientific test being used, and the belief that the courts have and the police have, that scientific tests were beyond reproach.

So, science has been put very much under the microscope and the disclosure for all the relewant material was something that went wrong in the Birmingham Six case. And had gome wrong in other cases like Judith Ward.

But additionally, there again what the police there did, was having cropped some positive test, then they set out on the lask of getting the evidence. Birmingham police officers are now on trial, not at this moment, but will be later this year, because there is a kery strong suggestion that they have fabricated part of the notes of the anterviews with sonte of the defendants. The defendants themselwes. indicated that they have been threatened and bullied into making admissions.

It is a complicated case in which some of them said: "Well I did say these things, but they weren't true for I was frightened and put in fear." Others were saying "Well $I$ said some of these things becalase I was afraid. But some of these things I didn't say" and others say 'I never said any of this'. So it was a thixture of erratic things in that case but again it was illustrative of the fact that if the police wanted to manipulate, il was very easy for them to do. And fundamentally the real evidence against the Six cante down to the scientific kest which are now discredited and the oral confessions again, which ate now discredited. Similarly in the Guildford case it was principally confessions and the Guildford officers are on trial now at the Old Balley. And the judge is desperate for the officers that they will be acquitted and is doing anything he can to ensure dhey are acquitted. The jury seems at the moment fo be biking on that and what will happen I have no idea but it only relates to one of the Guldford Frour that the Surrey officers are accused of. But certainly the Court of Appeal and the Crown dropped the case against all the defendants because they felt that the dishonety of some of them contanninated the whole squad. And they dropped it all. So there again is an illustration of bise police feeling that the confessions evidence was the best way forward.

In the Maguine Seven case, that again is a case of non-disclosure, it is a case of scientists being economic with the truth about the specificity of the test of the nitroglycerine at a similar point in the Birmingham calse.

And the tests used in the Maguire case have now been rewiewed, reappraised and are not considered to be reliable anymore. All this is in retrospect.

So I think the llessons of all of this period to me is very clear, that the police carnot be trusted, any more. Not as low ranking officer, nor as high-ranking officer. They cannot be trastred to condwct investigations unsuperwised and of course my proposition is this. I know quite a bit about the French 
system and $I$ am interested in having what they call a juge d'instruction "who supervises. I do not want the rest of the French system but a figure like that who is independent of the poice pendent of the judiciary, who is trained and paid independently to ensure that rules are not broken. proper imwestigation takes place and that only, when thete is sufficient evidience, people are charged. If is rather a different system from what we know. Because I don't believe that we are yet in a position to turn around and say "The police has got the point and they will never do it again." Because the Cardiff case shows that they are quile prepared to do it right up to now and after the Cardiff" case they said 'The officer in charge said they have got the righ people?

So they still believe they did the right thing.

So the police plamly still do not recognize they have done anything wrong in these cases. Until they do recognize, I am not prepared to let them go on conducting and supervising imvestigations.

Secondly I think there has to be a national scientific service which is available to all and not just to the prosecution. Opening up the government scientific service in the way they have, and privatising in this century hasn't really made any difference. And I think at the moment that the defence in these cases still hawe a grotesquely difficult task in trying to get scientists willing to and capable of doing the right investigation, examination. That links very closely to the legal aid. At the moment there is a cut back to the legal aid such that it is very difficult now to solicitors to be able to say "Well we have science tests." because the Legal Aid Board which deals with the distribution of legall aid questions every decision they take. "We can't have scientific test now. It costs too much we can only have iit up to this value. And we can't give the money now, you have to wait until after the case." So solicitors have to take considerable risks that their own firms have to pay at the end of the day for an investigation. A lot of firms will probably not bother to take the risk. Similanly, a lot of firms are mot being bothered to go out and represent clients in the middle of the night because they not going to be paid properly for it and so they just say: "We are not doing this."

So the thind thing is besides having an independent supervision of investigations, and besides having a proper cefence scientific serwice, the third thing is funding. And this government is not prepared to spend whatever the Royal Commission recommends.

CR: What about the Crown Prosecution Service. Has anything changed by this service?

MM: No 1 don't think they made really any difference. In isn't entirely their fault, because they have been underfunded themselwes from the beginning. They thave great difficulty in recruiting sufficiently qualified people, who want to do the job because they are being underpaid.

I think they are under severe pressure and are unablie to give each case the attention that it merits. I still don't think that they exercise the kind of control I am talking about over investigation, becaust they only get a case-file when it is too late, as somebody has been charged. They might get a phonecall early on: "Should we charge someone with this or that?" Or they might get a phone-call if they have to deall with an informer.

Basically they are a referral agency, they only get referred to. Police officers in charge feet they have to get some legal advice. But basically they are not in control. And they have got so many cases they go through, that they are not really in the business of saying that's a case that shoutdn't go any further.

They sometimes have papers sent to them about the possibillty of prosecuting somebody. Nomally, $f$. if the police officer has done something wong the director of the public prosecutors will decide and then usually decides not to prosecute f.e. in the West Midlands. ${ }^{\text {wan }}$ Normally they are against prosecuting police officers but in the awerage run of cases that come through io them after people have been charged they are not in the business of abetting them and deciding "I drop that case". That's what the CP5 stould be doing. Too many cases go through. The Crown Prosecution Service is just a huge atoministrative giant that actually doesn ${ }^{\circ}$ exercise sufficiently independent judgrnent at all. They ought to be scrutinging anything and every case very carefully, They only prosecute when there is a 50 \% chance of success. Some of these catses should have been stopped al a much earliti stage. The Magistrates Court doesn it stop cases either. In my 25 years there is one case stopped on

1011. Vgl. Rose, 1996, p. 318-319.

1012. Enkele jaren geleden kwan naar boven dat eer speciatle afdeling van de politio in de West Midlands zich op grote schaal schuldig makte an laet wervalsen van bekentenissen. In 1989 is die afdeling opgethenen. 
a commital of trial by a magistrate. They are not cowrageous. They feel they only have to rubbersump at. They are called examining matigutrates, but they don't examine.

CR. Should the police become more accolntable? And if so, in what way?

Miv: They could become nuwe accountable through the fuge, because the independent person who takes the dexisions. And they wowld be wccountable to ther (in Fince it is often a womany and they have to go back to her and say "what do we do from here, what do we do next". And if there are breaches of any code or rule and so on the jikge discovers, then she would want an explanation on the spot as to why they huent done this and they haven't done that. That is one formal accountability. There is another formal accountability which is extremely importan, which is hure (in Erigeland. $C R$ ) there is supposed to be, and the present Home Secretary has been trying to undernine it somehow form of local accountability to the community by having a sort of police committees if you like.

There you have some local counsellors and magustrates and so on who are sitting on these committees deciding how much money will be spent on police activities in the particular area. Except the Merropolitan Police that are directly referrable to the Home Secretary.

The Howe Secretary wanted to change all that although he was opposed by the police this year, because of course they want to mainkain their own autonomy and at the moment they are the third bit of this tri-partite committe, (magistrates, coungellors and police) and they are not accounable to the couneil in the normat way that other commitues are. They are autonomous and the Home Secretary's idea is to have a third party that was going to be representing the business community in a particular area, which I thought again would be made accountabile. I would want to change all that in any everut.

The police force says "We are serwing the community." They actually pretend they are serving the community. If they really mean that then the community should be in charge as well as the juge in the day to day matters. The community can not decide how an inwestigation should be carried out. But cllearly the community should be able to say when something has gore wrong, why it has gone wrong: "We want the chief officer here in front of us and we want an explanation". Secondly: "We are not going to allow lum to accumulate rubber bullets in the backyard of the police station. "Thirdly they can sel guidelines or parameters for the police within with they must operate along with the juge. If anything goes wrong, the police officer has to go to that committee to answer. The committee should make up I think, not of locall politicians, who are cameer politicians, and have one thing in mind, not of magistrates in from of whon the police appear everyday of the week. So they have a special relationship with the magistrates who back them up all the time. And certainly not of the business community. I would like to see it being a fairly broad-based committee which represents people who are not being represented, maybe communiry groups, they may be schools, they may be hospitals in that area. So it is that kind of conception I would like. That form of platform, we dont have that here at all. So there are two forms, professional accountability and the community accountability.

CR: The Royal Commission on Criminal Justice will peport this year.

MM: Yes, in July.

CR: What do you expect from this commission?

MM: Well I expect that we get two difterent things. I would like them to obviously recommend a lot of these things. But I think that, there are a large atumber of anembers of the Royal Commission (as many as 15) and I think in the nature of the kind of people they have got there, we will end up with a large neasure of compromise which will have suit nobody ath the end of the day and I think what we will actually do is necommend cosmetic changes which then cost a great deal of money so the pulvic will think that they are actually being taken, but won't as I say, involwe massive change. 1. think it will be a few things here and there.

I hope they don't abolish the right of silence but they might do. I think they are going to reguire a greater disclosure by all parties in cases; defence and prosecurion as opposed to disclosure certainty on the defence side, and not on prosecution. I think they have to do something about appeals, because the clamour, the public and the professional clamour that the court of appeal has been so bad and its record thas been so bad, in dealing with fresh evidence cases that I think they can't duck it "they lave to come up with a solntion. And think they are almost certainly going to reconmend a new 
body, a new review body. My fear is, that it will be another professional body dike the one we have got at the mornent. My proposal is very different as to how it should be done.

But I think that, even if they are radical, even if they do stugest reat chatages in the criminat system, the Hone Office or the Treastry will step in and just say: "We haven't got ine money."

So I am very sceptical about what is really going to happen. And it will be a tremendlots build-up of the Royal Commission's report and it will then be an opporamity missed for we wonit get one again for another 50 years, and probably with more miscarriages on the way. But I think the potice presence on the committee is very strong. And ll think there will be a lot of resistance to complete change. What it is going to be is givang with one hand and taking il away with the other to satisfy this or that group. There will be no real changes. And f.e another one which wouldn"t cost money. but I don't think that they hawe the conrage to do it, is that I dor't think there should be any prosereution based on confessionary-bnily cases. In fact a large number of whese cases are confession-onlly cases. They won't even cower up the ground. They wont do that, for they know, as everybody elsis know, that confessions form a crivical part of a lat of prosecutions.

CR: In Holland there is a tendency to comm nearer to the English system. When someone confesses the crime that will be the end of the case.

MM: That I gather is happening in ltaly ws well. And $\mathbb{I}$ am actually rather concerned there are so many wrongly conwicted people on the basis of confessions and only confessions, that I calat see that anytrody conceivably any whene in the world decides that a confession is a reliable sort of eydence even if the person says: "Look I assure you I did." Because we have had so many people say ing "I assure you I did". And they discover ten years later that they didn"l. For all sorts of reasons they confessed. They might help a friend or might be vulmerable. Judith Ward, my Cod, she confessed to loads of crimes, lots of times and to lots of different people. Then they discowered she is just susceptible going around and contessing crimes. But if you want to believe har, you do believe her. And they did believe her at the time. I don't know how mamy examples people really need but it seems to me that we got to the point in this country here with the thistory of unreliable confessions is so mountainous that you don't need anymore proof. We now have to be looking towards the situation in which we are looking for other ways of proving guit, other than a confession. And that is you know, ii might be circumstantial evidence, it might be scientific evidence, mith be eyo-witness evidence, it could atinost be any other kind of evidence than what the person himself says. And interestingly, in England, up to about $1898^{1013}$, the defendent was not allowed to give evidence on therr own belnalf. They had to stay silent. That was the whole point predicated on the idea that the state had to prove the case. The defendant had to do nothing and in fact was obliged to do nothing. There is a switch now. I think that it is wery distressing that they are in Holland thinking of coming ower to the English system.

CR: Did you giwe evidtence to the Royal Commission?

MM: Well, I was gong to write a submission. But, to be horest, I couldrit in the end get round to do it for I was writing the book. But what 1 did was done on film by the BBC on Presumed Guthy. So I seat them a copy of the film. Ban I atsis hawe given evitence to them becanse I represented

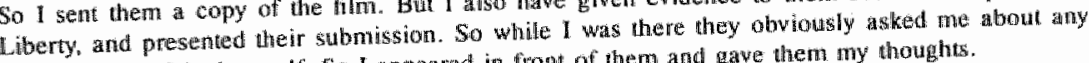
other jea that 1 had myself. So 1 appeared in from of them and gave them my thoughts.

1013. Zie ook McElre en Starmer, $1993,0.60$.

1014. In Engeland en Wales kan iedereen zign mening kenbaar maken atam do Royal Commission Van Mansfield verwachite ik da hij schriftelijk zou reageren op de opdrach wan de commissie, a angezien hij in enkele grote IRA-zaken als barrister opgetreden had en ieen kritische houding tegenower de polnite heef. 


\section{Interview met Chris Mullin, Member of Parliament Schrijver van Error of Judgement, 1990 \\ Londen, 13 mei 1993}

CR: What cas you tell mie about the Royal Cormmission on Criminal Justice?

CM: The Royal Commision was set up after a series of very large miscarriages of justice were exposed and its original purpose was to investigate what had gone wrong and to suggest some remedies. In fact, by the time it came to do its work the agenda had changed, slightly, and there were mary (the Home Office, the pollice, and the Lord Chancellor's Deparment) who saw it as an opporwurty for making it easier to secure convictions. They would prefer that the Royal Commission address the question as to how so many guily people go free, rather than how many innocent people are imprisoned. So part of the Royal Commission will be addressing that question, $f$.e. they will be interested in the right to silence. Ax the moment you don't have to say arathing. They will no doubt recommend the abolishung of that. They report in June. The funny thing is that the people who most usually demand the right to silence are police officers when charged with criminal offences. Three arte there on trial at the Old Balley at this moment $f$,e have just done so. In the Birminghan Six case the chicf constable of Dewon and Cornwall who conducted the investigation against the West Midlands police said that about 54 or 55 officers he sought information from declined to answer any detalled questions. They don't see the irony. The police keep demanding to do away with the right to silence but they don't see the irony.

CR: What do you think about the police? Should they become nore accountable or should it stay as itt is?

CM: Police are in theory accountable. The local forces are accountable to a police committee which consists of elected counsellors - whatever political parties are locally -, phus magistrates. The big weakness is magistrates, because the magistrates plus the conservative counsellors means there is a permanent conservative majorty basically. In any case these organisations are treated like a rubber stamp by many of their chief constables. On the rare occasions when there had been confrontations between the chief constables and the police authority such as there was in Liverpool where a liberal lady, called Lady Simey was in charge and some confrontations between mr. Anderton in Manchester, who was then chief constable and his police awhority, it is usually that the chief constable won. They have quite a lot of resources to entertain the authority, as a free hunch, flying in the police helicopter and then suddenly there is no serious questioning of their activities. That has been the trend. In the West Midlands where you might think that there was some scope for inquiries not just in relation to the Birminghan Six case but in relation to an enormous raft of corruption that has been uncovered there, even the officers from the Police Federation, which is the police trade union ${ }^{\text {ias }}$,

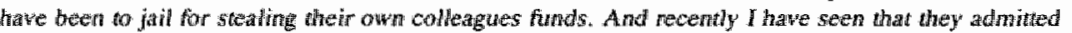
that property found on diead bodies has been stolen by the police. It is an endless saga, It is a large number of people who hawe been convicted on the basis of false confessions. There is only about one member on the police authority there who had asked serious questions and he or she gets no help from the chatrman. I would say police authorities up to now with certain exceptions either lack the powers or the will to hold their forces to account. The Metropolitan Police is still less accountable. In theory they are accountable only to the Home Secretany. And the Home Secretary has no time and no inclination to take at detalled interest, which is a pity.

ClR: But you can do as MP!

CM: Well we can do, but we don't get much in the way of answers. "It is a matter for the Metropolitan commissioner", is the usual answer. There is a very good Metropolitan commissioner at the moment, nor. Condon. He came before the Home Affairs Select Commintee a few weeks ago. He gaves sone very honest answers to questions about the big problems in the Metropolitan Police. In particularly, the is the first police officet I have ever heard of to identify publicly the concept of nobie causen corragtion. That is to say, when you believe in the guilt of the defendents you can justify to

10L5. Chris Mullin bedtoelt thier geen echte vakbond mee. Agenten mogen zich ummers niet aarnshunten bij een vakbond. 
yourself making up a few things to fill in some gaps in the case against them. He explained this concept which you will find in the interview. Then I think it ${ }^{\circ}$ low many police officers who justify things that been going on many years. An officer of the Polve Federation said to me prituately some time ago, I should say the Polsce Federation"s aim is to defend every single police officer who gets inte any difficulty. But in private he said to me: "There is nothing wrong with perjury, committed by a good honest police officer in the good cause." Now, I think that is the unofficial thinking that is a big problem.

CR: What do you think about the accountability towards a police committe? Should it be mone? CM: Yes, but the Howe Secretary has plans to make it all less accountable. "ot They want to get the councillors off, the elected people. Because if there is any trouble at all it will come from people who are elected, not from magistrates who are appointed. He has made some proposals. He is proposing also to have a London Police Authority, because he has acknowledged a few weeks ago that it is a problem not having a London Police Authority. And indeed the police themselwes want a London Police Authority. The problem is they don't want an elected one, because Labour sonetimes wins elections in Loudon. We won the Greater London Council, the Metropolitan Authority, the Headquarters of which you can see from the window over here, that building has now been empty for the past six years because they abolished it. They lost elections, so they abolished it. ${ }^{1013}$ Although we are one of the largest cities in the world, we probably are the only one that doesn't have a Metropolitan authority, responsible for transport etc. That how it is in this country, we atre an one party state: ${ }^{\text {"018 }}$

CR: Do you think that the police should be accountable to the Parliament or to the local councils? CM: I think the best method is to local authorities. To the representatives of the people who dhey serve. And therefore I would remowe the magistrates rather than the elected counsellors. It naty be wise to have the magistrates representer. It may be wise to have several different arganisations represented. The first step you can take would be to give votes on the aunhorities only to people who are elected. That would make a difference. But I think there needs to be, you see as I say in my evidence, an overthaul of police recruiting procedure, training procedures etc. For many of them thave no idea how to conduct even an interview. Disciplinary procedures, because at the moment very little happens to anyone who gets caught, for misbehaviour. I can say that f.e., to take an extreme case, there was a man ten years ago called Steplnen Waldorf. They were after an other criminal, sorry they were after a criminal and they ambushed this man by mistake. Armed detectives with guns, and they fired, I am not absolutely sure about the exact number of bullets, 14 shots alltogether into the car, 5 of which hit him. And when he was on the ground with all the bullets in him, there were witnesses saying they were kicking him. They all came up charged with atrempted murder and they were all acquitced. It is nearly impossible, if you can't convict in a case with absolutely clear evidence like that, what hope is there? It is nearly impossible to convict a policeman. You can convict them on disthonesty. They get caught fiddling the Police Federation's funds fe. That is a real crime, to take money from your colleagues! They all understand that, those guys were barmed. But beating up a prisoner or forgeing a confession is not treated with the same seriousness.

CR: Do you expect that the local authorities have the power bo change the policy or even the buthaviour of the police for the better?

CM: The police Authorities have not that much power at the moment. You don't have lo only rewew the composition of the local police authorities. You have also to review whether they have sufficicm. powers. Fen for the time being there is an wnderstanding at least that it is not their business th taks an interest in day-to-day matters. That is probably right, to deal with overall policy Bur that is certainly far too strictly used in the past, so maybe you have to revise their powers. You also need to inject some backbone, because even when elected, it is exuaordinary how well they seem to get on with the local chief constable and his men. There has been an improwement 1 think in the quality

1016. Zie ool 222. H.C. Deb. Gu Ser, kolom 933.

1017. De Greater London Council bestaat niet meer sinds 1986. Dil geschiedde op basis wan de Local Govermnient Act 1985. Zite Wade, 1988, 114\%115.

1018. Vgl. Huttom, 1995. 
of senior pollice officers in the last years. In Northumbria, the police authority that covers the area my consturency is in. wave a new clater constable, John Stevens, who is a very capable man in my view. He has introdtuced some wery useful chamges and in Sunderland, the town li represent in Parliamen, we have some very good police officers. The big problem ap to now has bean that it could actually occur at the lower level and both involved ${ }^{\text {notig }}$ get caughtu, but they get caught in the witness box in court telling enormous lies and the judge sometimes writes to the chief consable saying "This is ounrageous". Nothing ever happens to these people. As long as nothing newer happens to these people nothing is going to change. Because the word will be passed down, but at really does mot matter if you get caught. That is the climate. It may be changing. There will be an enormows number of retifementw, just very often by people facing disciplinary procedings at a very young age. 30. There is always some reason why il never actually gets sorted out. In the Birmingham-wase, so tar als I know nobody suffered more tham mild inconventence as result of their involwement in that case. In the Guildford case when the trial trok place in 1975, the following exchange took place between the judge. Lond Donaldsen and the prosecutor. Michael Havers. Lord Donaldsen said: How many police officers would have to be lieing ${ }^{x}$, no berween Lord Donaldsen and the chief consiable of Surrey, whose name is Mr. Rowe I think, "How many police officers would have to be lying in order for the defendants to be telling the truth?" And the reply was: "About a hundred: my lord." Well. two sergeants and one inspector lave come up at whe Old Bailey 14 years later and as I say. I think they will be acquited, but wait and see. In the Bumbingham case the trial judge outllined at considerable length the scale of forged purgery that would have had to occur for the defententan to be imnocent. And he did so. In lerms of increduliry, he was saying to the jury: Look, you lhawe to be mad to think that conspirary could exist on this scale. Ho would have to involve two police forces. officers ranging in rank from detective constable to assistant chief constable. Police officers who have never met each other before the night when they canne together to caich these men.' He spelled it out ower two or three phimses. Much more clearly than I could spell it out, one has to reread these words in the lines of what we know now. At the time it semed that he was making a very reasonable point, but now he was describung in scale of what did happen. And now noborly wants to know about it anymore. It is all in my book.

CR: What about the pollice working together or hawing close contact with the government and the conservative party in England. I ask this question in relation to the miners" strike of 1984-1985. Robert Reiner fi.. says there was close contact between the police and the NRC. But the government and police oficers demy that.

CM: When mrs. Thatcher was ellected in 1979 she knew that she was going to need a bot of police to help her gef through certain industrial changes that she wanted to get through. In particular to break various strong trade unions, of which the strongest was the miners', but not the only one. And instead of looking for criminals, they would be required to deal with various sections of the working class. And they waited wery carefully. They firstly gave two or maybe three enornous payrises to the police. The pay beween 1979 and 1984 went up massivelly. And hawing purchased the loyalty of the police in this way, they them used them extremely ruthlessly to break the miners. You have been told there is not a national police fotce in this country, but there was for that period. There was

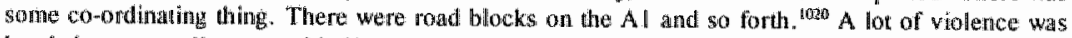
handed out as well some of it timed by television cameras, which caused a lot of embarrassment. Nobody was ever disciplined for the violence that occurred. In fact the press were also fairly friendly towards the government. If you read most of the manstream press, you would get the impression that any violence was simply the work of the miners. In fact there were one on wo very interesting trials

1019. Mullin bedoelt thier agenten.

1020. Tijdens de mijnstaking van $1984-1985$ probeerden stakers te verhinderen dat mijnwerkers in (andere) mijnen wel door gingen met hun werk. Ze reden daartoe wel eens met hun auto's nasi mijnen in andere delen wan Engeland. In sommige gevallen probeerde de politie te ve hhindteren dat de stakende mijjnwerkers naar andere minnen toereden, Om die reden wewden de autowegen in Engeland in die tijd zo nu; en dan geblokkeerd voor stakende majinwerkers. De mijnwerkers wend dan meegedeeld dat ze rechwomkeer moesten maken. Ower het algemeen gaat men ervan uit dat deze actie uitgegan is van de overheid. 
that recerved very litte publicity. In one case about 20 or 30 miners were placed on trial accused of attacking police officers in Sheffield, and another incident had supposed to take phace at Orgreave. They involved a total of around a 100 defentants, all of them miners accused of assabling police officers. And in both cases the police were caught out lying on very large scale and all the cases were throwin out.. In one of the cases, it's the Orgreave trial, the Hincident took place in Orgreave, what happened was: all of the police tripped into the witness box one after the other amol say ing that they had been the victim of this totally unprovoked violence and it had been necessary unfortunately 10 strike back. All the initiative had come from the miners. They had forgotten litiat some months previously they had been obliged to disclose the police video of the event. And so when all this purgery was on the record, the defence just asked the magistrate if they could haw a litule fitmshow." and they turned on the catnera and it showed this peaceful holday atmosphere. The sun shiming, roiners stripped to the watistline, sunbathing, and suddenly this wall of shields were dansing towards them which opens and people on horseback come out and that was the end of that trial. But you see: unforturately no publicity. The miness and for the printing workers as well - Mr. Murdock decided to sack 5.000 printing workers. He required lats of police to fortify his headquarters in East-London. 1000s of police and they behaved wery badty there too. Both were landmatk casts. Onte of the weaknesses in our system is that one police force investigates another, but sometimes particularly when a smaller police force is concerned they do do an honest job. And they did in this case and hey recommended the charges that were brought against various police officers and these charges were brought against them and they were all acquitted. They didn's even reach court. The magisirate chucked the case out. One of the interesting things that occurred in the last two years was that almost all the big cases involving policemen charged with criminal offences came on remand before the same magistrate and the same court. No matter where it took place in the counury, he always did the same thing. He said there was no case to answer. His name is mr. Rouald Barker. And I looked up, he has writien a book some years previously which was published by a very obscure relighous publishing house, and in the said in so many words "(he) had never come across any police officer in his career who lied or exaggerated to the slightest extent and it was inconceivable to thear that a police officer could. "I sent it to the Attorney-General and it got some publicity and Mr. Barker has stopped taking these cases now, but he did rescue all the Wapping officers. ${ }^{102 t}$ llt took the Guildford officers four years to reach trial. It is four years since the forged confessions were discovered and one of the reasons for the dellay is that they came before Mr. Barker who chucked it out. And this was at the time that 1 found this book that he had written and the Attorney General went to the High Court of Appeal against his decision and got it reinstated. And so that is why they are on trial . But we have a phenomenon, probably you have in Holland, but it is wery strong here, called freemasonry. It is very strong in the police and in the legal profession. And you cannot be sure that the judiges or the magistrates or the police officers are not freemasons. One of the aims of freemasonry is mutual self advancement. I think you can find that numbers of the chairmen of the police authorities are members of the same lodges or similar lodges as the police officers they are supposed to be oversee.

This does not make good justice, but freemasonry is a gecret society and it is very hard to get the truth of it. It is very strong in this country over half a million and all male and miainly middlechlass. You can work out that it is a fairly large section of the middte class male population. And in the police very intensiwe indeed, and in the legal profession. All these things conspire against opent government. It is an one party state. From time to time another party is perrivitted to the over the Lower House for a few years to take the blame for what happened in the previous 14 years, but the n: everything reverts to nomal. But even whet they loose control over the Lower House they still hatwe permanemt and absolute control over the Upper House of course, the City of London, most of the newspapers, (certainly the overwhelming majority of the taewspapers are controlled by friends of the conserwatiwe party) the military, intelligence services etc. It is only the Lower House that is changing thands and if you look in this country in the last 300 years the conservative party has been in power for most of the last 300 years. There has been half a dozen gaps in this century. The only time it has. changed a lot was in 1945. From 1945 till 1951. I can"t think of any odher period. Under the Lloyd George government - a liberal government - in the begimning of the century they changed the landsca. pe, but beyond that the conservative party has always been in control of this country. We never have beet inwaded for 1000 years; whe had no rewolution. So all the big landed founders are still in control 
and they are atliepresented in the House of Lords. Some families hwe sat there for 600 years And they live in casties. I remember when there was a march for jobs by unemployed people from Glasgow who walked to London sime years ago. They said they walked for two days without leaving the land of the same landowner. In Northunbria there lives a duke in a magnificent castle and the owns most of Wortumbland and the parts he doesn"t own, are owned by the Ridley family. The Ridley family has been represented in the Lower House, mever minul the Upper House, for 5 or 6 generations. Nicolas Ridley who died recently was a cabinet minister. Once or twice a year they open the garden to the public and they give the proceeds to the red cross. I went along since it was a chance to get in the place where you can't otherwise get in to. And another world exist belind walls: its own roa network, its ows communities, its own petrol station, its own fire-engines, in"s another planet and that is what are the liwes of the Conservative Party.

Joltn Major salik the other day: "The conservative party is the most powerful political machine in Western Europe.' And he is absolutely right. There is nothing like it. Nobody knows where the money comes from. Most conservatives couldn't tell you where most of the money comes from. Suddenly 20 million pounds appeared in their coffers just before the last elections and in the accounts there's only an account for about 7 million pounds. Nobody knows where the rest comes from.

You are not in a democracy here. Don"t get me wrong; we haven't been unaded, we haven't had. a rewolution. That are some adwarntages but we have a culture of limited politicall tolerance not unlike Yugoslavia. ${ }^{102}$

CR: Does the image of the London "bobby' still stand? Is England still very proud of its policeforce? Sir Robert Mark said in 1977: "We have the most accountable police."

CM: One of the things that rulers say from time to tine, and they dorn't say it so much nowadays. interestingly enough, is that we have judges who are the best in the world, police are the best in the world, etc. ${ }^{1023}$ It iis a phantasy and a delusion.

What we have is the most arrogant, selfimportant rulers in the world, but not the best. Certainly true about judges. But now you wontt hear them saying the judges are the best. They got caught too many times recently. Sir Robert Mark sacked 800 Metropolitan policemen. He did his best to try to clear up the corruption. Considered the situation in the Metropolitan Police at that time in the 1970's the pornography-squad went to jail up to a wery senior level for dealing in pornography. The drug-squad. went to jail up to a very senior level for dealing in drugs and the serious crime squad was investigated but nothing proved for involvement in armed robberies. That was the situation as it was then. It improved a bit since then I think, and we have got good Metropolitan commissioners, bat they are: up against a wave of difficulies.

CR: At that time the Police Complaints Board was established. Since then it was changed into the Police Complaints Authority. Is the Police Complaints Authority successful?

CM: No not in the slightest. The PCA is a complete waste of time as any honest member of the PCA will tell you priwately. It is one of the lleast effective institutions that exist. And indeed no solicitor these days who knows anything about police complaints would ever advise a client to take ai case to the PCA. What you do is sue, and that is the trend now. People ignore the PCA and there have been wery big damages settements against police officers, because the police usually fight till the last moment that it reaches court and then they drop their defence and they have to pay a lot of money. Some figures have emerged in the last few weeks for the amount of money the Metropolitan Police have been paying out. A several million a year up thi how and it is bound lo go up even more dramatically. 1 asked the Metropolitan commissioner on the Home Affairs committee if he could provide the committee with details what has happened to the police officers involve in cases where more than 10,000 pounds in damages have been paid out. There were about 50 of those cases over 5 years. Many more for lesser sums. But 1 went for the big ones. Three or four were 100.000 pounds in damages. And he did send me the detaits and the answer was: There were 59 cases altogether. In 46. cases nothing happened, in 13 cases there had been some sackings and early retirements. That was better than I thought, for I thought that nothing would have happened to anybody. Even in cases that

1022. Onder Tito? Het is onduidelijk wat Chris Mullin hier bedoelt.

1023. Het nythesystem. 
inwolve more than 10.000 pounds payment and admiting to all sorts of very serious things, in 46 cases nothing happened.

CR: Except perhaps some disciplinary measures?

CM: No, no, that is what 1 am saying. Of the 59 worst cases in 46 of them nothing happened. And in 13 of them something happened varying from minor disciplinary procedures to being required to resign.

CR: Can you still trust the police in England?

CM: I have met a lot of policemen, honest police officers, who deeply resent the state of affairs that we have here, and I have to say that many of the ordinary uniform police are not bad people. Many of them get coopted into the cutture where, f.e if you were to give evidence against a colleague that is the end of your career. There is only one case in the West Midlands that $I$ am aware of that at policeman gave evidence against colleages and that was in a case of a 17 year old cadet who had been in the force for two days and did not understand how things worked. His name was Adrian Dart and he made his first arrest. It was a man who was, accused of stealing some goods from work. He rook: the man to the police station and handed him over to two dielectives who were to conduct the interview. And he heard screams coming from the incerviewroom and then the door opened and the man was dragged out semi-conscious between two of these policeman and a third one was mopping up the blood. And this was just for a very minor offence, we are talking about. And this man ${ }^{\text {tond }}$ was acquinted. So he $e^{\text {toss }}$ reported this and instead of receiving help from his superiors, he was instantly moved to another force. That was probably the right thing to do. He found that his life becane hell. He found death threats in his locker, his ty nes were let down or slashed of his car in the carpark. In the canten, officers up to the rank of chief inspector would all get up and walk out. He got abused. he got threatened, and they went to the headmaster of his school and tried to get dirt on him but he stuck to his guns and these two police officers went to jail. And this is probably the only recorded incident of a pollice officer giving evidence against colleagues. No need to say, he was driwen out of the police force.

There was a case in London I saw last year, which I thought was quite encouraging. Seweral officers from Hammersmith gave evidence against a colleague, accused of assaulting suspects, and the people inwolved were conwicted. That is an encouraging sign, what one wants to know is what happened to those two police officers. How llave they found they get on? The culture would change providing honest police officers had support from above. The culture would gradually change.

If you the fremasonry for example, it is deeply resented by police officers who are not freemasons because they suspect that their promotion chances of those who are not freemasons are not so high. I have a lot of policemen contact me and say" "You have got the majority of policemen on your side", and I believe today at the Police Federation conference they are debating freemasonry. I introduced hinere a bill to try and require disclosure of membership of secret societies. It receives quite a bit of publicity and people have started asking their lacal oflicials, not just police officers. whether they are masens or not. Aatd now it is on the agenda of the Police Federation. So look in tomornow's paper and you may find it reported. There are a plenty of honest police officers but they don't get the support they deserve. Where the rot is at its worst is in the detectives squads, like the most serious example is of course the West Midlands Serious Crime Squad, where detectives becafne completely loyal to themselves. People stay there for 15 or 20 years with the same squad and the same people and they developed practices which became part of the cullure. Those are the big problems: drugs squads, pornography squads and the crime squads. They don't weat uniforms, nobody keeps a check on how much owertime they work and sitting in a pub drinking and collecting intelligence and there are plenty of opportunities for doing deals willo criminats. That is at very problematic area. But there are plenty of good policemen and in fact you must notice that the only reason the Guildord case was brought to a good end was because the Awon and Sumpretset Polioe carried out a proper investigation, although all enormous pressiure was put on the Home Secretary to order an inwestigation, and they found these forged confessions, the early drafts of the forged confessions. And that case came to an end. Now, they could have overfooked that if thaty choose to,

1024. De verdiachite.

1025. Adrian Dari. 
but they didnt. These are all snall provinchal forces and they are giving evidence against big Metropolitan forces. The Dewon and Cornwall Police finally brought the Birmingham case to an end. They carried out an honest investigation. But they carried out not a very honest investigation prior to that. More pressure had to be applied but in the end an horest policeforce and an thonest chief constable conducted a proper investigation. There are plenty examples of that. It is not uniwersal.

CR: At this moment the police officers in the Broadwater Farm case ${ }^{\text {ine }}$ are at tral? Do you have why expechatitonis?

CM: Yes, there ato some prosecutions in that case, I think. They always mysteriously delay. Years go by. It has talken in the Guildford case these guys four years to reach court and the trial is a fiasco. The judge told the jury: "You can abandon the case anytime you want. And the prosecution is doing its job so poorly, that - one person I spoke to the other day said to me: "When is the prosecution case going to begin", she thought that what we had seen reported for the last few wreeks was the defence casse, but it is not, it th the prosecurion case. The prosecution agreeing with the defence's position that really these people did. if. The prosecution is saying: "Well, no doubt members of the jury we all hawe formed a view about whether mr. Armstrong was guilty or not. But that is not the point." The jury so far refused to abandion the case, but you only need to get four jurors to stop it. It would be an historic occasion, the convictions and then the judges would be requitred to pronounce sentence. And I sllould think six. months probation, six months suspended prison sentences. I would be very surprised if those police wficers go to jail. Even though it has cost millions and millions of pounds, and ruithed the lives of about 11 people. I will be amazed. The same thimg will happen in the B Brmingham case. These pollice officers are coming up in December. And the same thing will happen again in my view. The Crown expect from the outsel: "The Birmingham Six were really guilty after all but we regret that these police officers mishehawed." And the same may apply in the Broadwater Farm. That is the common theme bethind all these aases: "We know they' did it. Sorry we cart actually produce evidence that will stand up in court but we know that they did it." And they will get support from a section of the media: the Sun newspapers f.e. I get lous of letters accusing me of being an IRA-supporter.

\section{Interview met Alastair Logan, solicitor in de Guildford-1027 en Maguire- zaak en de Judith Ward-zaak Sutton Green, Guild ford, 14 mei 1993}

CR: Would it be possible to talk about the common links between the several miscarriages of justice cases which took place in the the 1970 's.

AL: It is very difficult. You cant be precise about that in a short space of time. They are entirely diterent catses. The common links are the fact that they were all cases involving alleged terrorist acts. And they were all cases involving peopte who were believed to be or accused to be members of the Irish Republican Army. At the end of the day atthough they weren't charged with offences of belonging to the IRA, they were IRA-terrorist cases and they formed part of a series of cases which included the Birmingharr Six, a case in which I didn"t hawe a connection. There was itio, sorry a quartet of cases all which eminated from 1974 . In 1974 the police did not have an efficient organisation to counter terrorism in this country and there was a considerable amount of terrorism going on. Explosintus were happening almost dlaily. People were getting kulled, property being damaged and the public was becoming increasingly concerned about the inability of the police to capture preople who were responsible for this. And it appeared that certain police forces decided that it was necessary that they would put people on trial for offences related to this and I think they found a number af people. They frightened them and as a result of dong so these people were prepared to admit they had done things which they hadn' done. And I believe the police knew perfectly well that the people that they got those confessions from were not the genuine article. But from their point of view it was convenient that they hat people in custody charged with these offences. They were able to get convictions in the Guildford case and the Ward case based on confessions alore. In the Birmingham case it was

1026. Ook bekend onder de Silcott-zaak of The Tottenham Three (Silcott, Braithwaite en Raghip).

1027. Vor mirs Richardson en mr. Armstrong. Zie ook The Times, 17 augustus 1990 , p. 1. 
a combination of forensic evidence and confessions and in the Maguire case at was foremsic alone. So that is really a sort of thumbinail sketch of those particutar casers.

CR: What do you think about these convictions based on confessions alone?

Al." Yes, we hawe said that these cases have exposed the weakness in the criminal justice systen of relying upon confessions alone. In is that in Scotand which has in fact a seprrate legal system that they have an arrangement wheneby people who confess to crinuinal cases cartuot be tried on the basis of that confession, unless there is some other evidence which we call corroboration; which supports the confession. So what you are looking for is a confession on the one hand and some other evidence which supports that confession. Without that evidence in Scotland there is the theory that you cannot prosecute on the confession alone, but the Scotish experience shows that what the courns have done there, particularly the judges is not to look for a piece of evidence which is completely outside the confession but to look inside the confession, finding things what they say support the confession. It is a wery convoluted intellectual argument but it is the refuge of the judge who has no other why of ensuring that somebody is comvicted for an offence. So instead of looking outside and sayling well he said in his statement that he went to the bus at half past fwe and there is the busman who says: "Ves he got on my bus at half past fiwe", so now you hawe completely independent evidence. What they say is: "Well he said he was on the bus at: half past five, and we went to look at the thmetable and yes there was a bus at half past five." And that doesn"t prove anything. And that is the way in which it has gone in Scotland. So what we are saying here if if there is to be a rule which prevents. confessions from being used the wule must specify that the independen conoboration must be outside: the confession. It must be a separate piece of corroboration altogether. So that is the proposal that I support and it is supported by a number of other people and organisations and has been submitted to the Royal Commission, that has been appointed to consider changes in the crimuinal justice system, as a result of these cases.

CR: Were the mistakes in these cases all made by policie officers?

AL. Most of the evidence with the exception of the evidence in the Birmingham Six case, that was of forensic natre and the evidence in the Maguire case, was evidence which came from police officers. So let us deal with the Birmingham Six and the Maguire case. Where there was forensic ewidence the police had no role to play in the sense that they were not the people who carried out the examination of the evidence and produced the seientific repont that said that in the case of the Bitmingham Six some of them had been handling explosives and in the case of the Maguire Seven all of them bad been handing explosiwes. That was done by scientists. And the police had no influence on that. That said, I personally have always believed that Ann Maguire was convicted on the basis of evidence which was planted by the police. I believe that the police tainted her gloves, because when she was tested for explosives she was negative on her hands. And nine days later they then find a glowe of hers and they say that this glove has got nitroglycerine on it. Duriug that time the glove has been in the possession of the police dill that time. And I think they knew very well by that stage that there was no other evidence on which they could hold Ann Maguire. And il think that they woctored it. The rest of them I think were found to have nitroglycerine on them because of an error in the laboratory which resulted in contamination from explosives effecting the credibilly of the

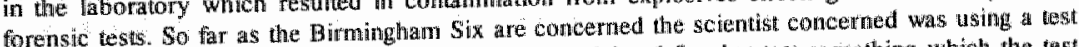
which was completely scientifically useless. And he clamed for that test something which the test could never have produced. He was bellieved in 1975 and they were tried. But subsequenty when the test was subjected to critical scientific analysis it was found that it contd simply not prowe what he had said it proved. Moreover there where other explanations why the test might have reacted in the way as it did. And those explanations were entrely consistent with innocence and wot with guilt. $S$ o putting those cases on the one side, the role of the police in relation to the Gafldford Four and the Ward case: in the Ward case they had a gtrl who was, well I am sure ever country has ins own description, in Ireland they would have said "she wasn't a full shilling", in England they would bave said "she was a bit simple". She was a girl who not really simple but she had quite sewere psychiatric problems. And the result was that she was more than usually susceptible w pressure placed upon her. She was isolated. She was an the company of male police officers throughout. They could sed that she was nol capable of looking after her ow interest properly. They wanted somebody for this bombing and she was prepared to wolunteer that she had done it. They dhen discovered by accident when they were checking up on her that wher she had confessed doing the bonbing she 
couldit have done it because she was a hundred miles away at the fime. And then they had get her to alter the statements. And instiead of doing the bornbing she gave the information to the people who did do the bombing. It was such a fairly disgusting reprehensable affair in respect of which officers behaved quite outrageously and wery nearly rumed the live of one poor indiwidual. It also has the consequentice of those people who have for many years drawn some comfort from the fact that people, whom they lowed, were killed or badly injured in the explosion. The persons responsible for that, have in fot now have to start thinking again about the whole affair and recognize that people who did do this bombing were not brought before court and were not put into prison. In the Guild ford case, the officers adopted the attitude that they would do a net sweep through London picking up as many people from the Irish connection as they could who were either thought to be connected or sympathetic with terrorism. Some 40 or 50 peoplle were arrested throughout that period of time. And they adopted the attitude that, if as a result of these arrests they actually picked up the geruine articles, somebody who was of the IRA, then they would have to prove very difficult in interrogate because the IRA have a farly summary way of tealing with people who talk to police officers. And therefore they might well be afraid that if they did talk to the police officers they might suffer in this way. So consequently they decided that they would persuade these people to talk to them. And there is only one way of doing that. If what you are afraid of is viollence then the only way you force someone to talk to you is to make them more afraid of the violence that you will do to them than the virolence they might otherwise get. Or, to give then a guarantee that they would not get violence from the people they were afraid of. Of course the police were in no position doing that. So what they did, was they behaved in a violent, threatening, wicious manner. And of the people that they had in the police station four people confessed to the Guildford bombing. And they were the four weakest people the police had in custody. They were people who were in the case of Armstrong and Richardson, misusing drugs and alcohol, living in squats, not taking proper food in time not sleeping well. having been abused, heawily drunk 48 hours before the arrest. In the case of Conlon and Hill they were people who could be frightened in other ways by threats made against their families. And at the end of the day they were prepared to admit what the police asked them to ardmit. One of the signiffcant factors of the Guildford case is that al they ever admitted was what the police already knew. They did not admit anything else. When it came to the Woolwich offence, which Armstrong and Hill were charged, the Surrey constabulary had not inwestigated the Woolwich offence, because the Woolwich offence pccurred in Woolwich in London, and had been inwestigated by the Metropolitan Police. So consequently the Surrey police knew nothing about it, except that a bomb had been thrown into a pub. Guess what, that was all the information they had got of them. So these confessions were merely reflecting what the police knew. And the police have a lot of, they have a great responsibility for these cases. "They stem from a period of time when they did not have the same degree of skill of countering terrorism as they now have and they made up for it by rallroadling people and then you seen the most curious thing happened. When the Balcombe Street Unit ${ }^{0 x}$ were arrested I was told that they could tell me something about the Guildford bombing. So I went to see one of then and he told me, yes he could tell me something about that. But he would meet someone else to give authority. Another man who had been arrested and was currently in custody. So I made arrangenents for that man to be seen by a MP. And yes he would talk about it. And as a consequence I ser up a series of interwiews. What those interwiews show was that the Batcombe Street unit had in fact done the Guildford bombing. and the Woolwich bombing and had done a lot of other bombings besides. What it also sllowed was that the police knew that, because the forensic links which linked all of those offences together were not only detalled but idiosyncratic. Consequently, what these people could say about these offences was so detailed that they had to hawe been present. And the idiosyncratic factors which linked the forensics were such that they lad to be done by one group. What the police were doing was concealing all those links. They did not say anything about it in the Guildford case. They didn"t mention any of the links. When it came to the Balcombe Street case they left out Guildford, they left out Woolwich, they left out some of the links. They falsified statements, and the consequence of that was that has waly until I saw the Balcombe Street papers that I was able to put the finks back in, because I knew what Guildford had done and knew what this one was and therefore I could see that there were common links bettween Guildford and these other offences and then we lhad a trial.

1028. The Balcombe Street Unit was een eenheid wan de IRA, die bomaanslagen in Engeland uitvoerde. 
We had a trial of the Balicombe Street Four. which was unique in the annals of history, in 1976. What happened in that trial was that instead of the police trytng the Balcombe Street Four for serious terrorist offences, the Ballicombe Street Four put the police "on trial" for teiling hies about Ouldoford: And the whole of the case that was num on behalf of the Balcombe Street frourwas not sayng: "We did not do it" but was saying: "You lied about Guildrond. And you said there were no links between Guiffford and any other offence. You know there were links between Guildford and other offences. Here are the links. You concealed them. Why did you do that?"

So the whote case was turned on its head. Instead of it being a rnassive public trial of terrorists, for awful terrorist acts, it became a rial of the police and why they had lied about Guidford. And then of course the Guildford people went up for their appeal and the appeal was knocked on the heart. So you get the inwolvement of the establishment. The judiciary ${ }^{\text {tow }}$ behaved quite outrageotsly in relation to those offences. The appeal should have been allowed. There was clearly a lurking doubt because not only had these people confessed to dong at, they had wrique information which could only have been known to those who took part. In the case of Guildford Dowd, who was one of the men I interviewed, was able to describe two elderly gentemen, who had sat next to him whilst he was planting the bomb in the pub. These elderly two gentlemen had newer featured in the case betore, but the police had statements from them. Statements which they had not serwed. So how could Downt know about that? O'Connell was in the Seven Stars public house in Guild ford. He said: 'I remember we were sitting at the table planting the bomb. We were just about to leave, when a soldier came up and said: "Do you know what time the last bus is back to Aldershot?" And he had to say: "No" " he didnt know. And there amongst the statements we had newer seen before was a statement from a soldier who had said that there was a group of three people sitting in a corner of the pub, and that he went up to them and asked them if they knew what time the lasil bus went to Aldershot. So that is unique, that is not just a possibility, that is an absolute certainty. How contd O Connell hawe known about tha? How could Dowd have known about the two old men? They described how the bonb was made. They found fabrics which mathed the fabric on the back. It described how it was planted, described all the other things. And of course at that rime we did not know what we know now, that there were forensic links which showed that the very way in which they made that bomb was the way that other bombs were made. And that they planted that bomb as the way other bombs were planted.

At the time they ${ }^{103.1}$ had a desperate need to calch somebody. And then when it bectame plain to them that they had got the wrong people it became desperately important that they should not be discredited. ${ }^{1032}$ So they set about altering all of the necords to try and eliminate any connection berween Guildford and the other offences. ${ }^{1943}$ But 1 mean, let's face it. It took 15 years to get them out. And that is not a credit to the record. And when a mistake is made, you want to correct it as soon as possible. You find very few people who would argue that 15 years of imprisonment is as soon als possible.

CR: In what way do you think the system should be changed?

Al. The system should be changed by ensuring that the police do not have the factlity of interviewing people without having adequate safeguands. A very safequard should extend to perople who are wulnerable, because of drinking because of drugs, because of psychiatric problems, because of age, even because of sex. It is intimidating. People were interwiewed in the Gubdford case by male police officers who were physically violent with them. They were girls who were under the age of 18 . Two

1029. Vgl. Huton, 1995 .

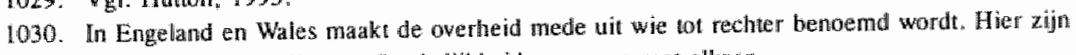
politiek en rechterlijke onafhankelijkheid werwewen mek elkar.

1031. De politie.

1032. Cover-up.

1033. Men zou dit de gewolgen van de hoble cause corruption kunnen noemen. Enerzijds wordt het eerkoudiger en meer voor de hand liggend om verkeard te handefen, aangexien dit gedrag door het korps meer en meer geaccepteerd geworden is (escallatie). Andlerzijds wordi het moeilijker om schuldigen taten veroordelen., wanneer blikk dat in sommige gevallen de politie het bewijs een handje heeft geholpen. 
of them. One of them had a percod while she was in he police stotion. They refused wo give her any santary equipment. Others they took away heir personal clothing and gave them soiled, unusable

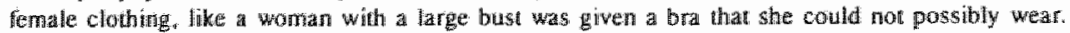
Or a girl will a small bugt was given a bra that wass too lage. There swere given sweaters that didn't fit. Clothes were taker away supposedly for fonensic examination. But it was taken away for degrading them. If was a way of humiliating them. How can you face a male accuser as a fomale; when you are noi properly dressed? You feel wunerable, you feell soiled, for you have not been able to Wake a bath or haven been able to clean yourself properly. And you are not giwen underpants that you can wear. In the case of men their clothes were taken away and they were made to walk thitough Hots of hostle police officers dressed by only a blanket. Thath intimdating. That must never haphen. Bur it did happen in this case. It happened "bectuse there was no control. The controll should hawe been by senior police officers. But these cases teach you that senior police officers get as unwlyed in the psychology of the case as juntor police offcers do. So we have to have an independent system. We need system whereby people who are in custody in the police station are in fact a responsibility of somebody who is not a police offecer. A trained civilian whose job it is to warehoust these people and to make sure that certain rulles and recognitions are obeyed. About who may wisit them, about what circumstances they may thave. We must make sure that all interviews are taperecorded. That all documentation in relation to them is done in such a way that it can not subsequently be altered. One of the wonderful things about the Guildford case is this: You could go down to the Guild ford police station and they will tell you that this was a perfectly honest and above board investigation and that the police officers did nothing wrong. 15 years later they find a duplicate set af custody reconds. Why do you need a duplicate set of custody records if this was a perfectly honest investigation? And those duplicate set of police records which they found tally with what the defendants had said when they where under crosis-examination at that tral about the visis that they had, the interviews that they had and what had happened to them. There are the records that are actually produced and there are the ones which tallied with what the police said had happened were different. ${ }^{10 * 4}$ And you see all these things come in and this is where the police have so much control.

CR: What can you tell me about the three officers who now have to appear in the Old Bailey?

AL. There are three police officers who interviewed Patrick Armstrong, who was one of the Guildford Four. They comprised a detective chief inspector, who is al senior man, somebody like a lieuteliant-colonel in the army, aldective sergeant and a detective constable. And they were changed with an offence of perverting the court of justice. Whet the Avon and Somerset police force took over all of the papers in relation to the Guildford case on the onders of the Home Secretary, in May 1989, at the commencement of the inquiry, they discovered in a file three documents. The original document, which was produced in Patrick Armstrong's trial was alleged to be a manuscript, in other words written by hath, record of exactly what he said when he confessed, in other words it was written down as the words came from his mouth. But in the file they found two other documents, and each of those documents had been amended so that the documents they produced at the trial was number three, and the other documents were numbers one and wow. "The first document was a typed document which that then been altered in manuscript. The second document started off being typed as what the first one was ifter it had been altered and the third document was exactly the same as the second document after that had been altered in manuscript. So what you had was a document that was altered, which produced a second document, which was altered, produced a third document which they told the court was ackually written at the time that he contessed. If those wo documents are what the Crown says they are: mainly that they are the precursors of this particular document, the police oflicers must hawe lied. When the police officers were interviewed, they did not give any satusfactory explanation of the docunents one or two. They were put on trial and what has happened is that instead of giving an explanation for those two documents they have tried to divert the attention of the jury by assassinating the character of Putrick Armstrong. They say: He is an IRA-man. He confessed to was. Does it matter whether we made up the documesuts or not made up the document, because this man is genuine. He is in the IRA. He is guilty. Patrick Armstrong is not in court. Patrick Armstrong can't defend himself. Because if he opens his mouth or intervenes in any way they will say he will try to prejudice the trial of these officers. But when if came to the question of giving

1034. Het blijif naturilijk de vragg warom de politie die gegevens bewald had. 
evidence, these afficers didn't do anything. They didn't go into the witness box. "They didn't give any explanation to the jury, they conducted the entirety of their case on trying to conwince the jury uat Patrick Hmstiong was a genume IRA man. That is what that trial all is about.

CR: What do you expect will happen in this case?

AL: I expect the result to be that the officers will be acquitted and I'd like the result to be that the officers are convicted.

CR: How is the relationship between barristers and solicitors in a case"?

AL: It is difficult. Yes we have like general practioner as a doctor. I am sure you have the same in your country as we have here; we have dochors who are giving medical advice and treatment and then you hawe specialists. Barristers are very nouch like specialists. There aren't wery many of them. And they tend to be used for specialsst tasks. Charges of the serious narure of the ones in the case of the Guildford Four can only be tried in a higher court. And before that court only barristers thave the right to appear. So consequently you lave to instruct the bartister. It is not always possible to make the barrister do precisely what it is you want him to do. There are a number of reasons for this. First it is that it is impossible to stop somebody when be is speaking, when they come out with something that has been said. Secondly, barristers are by the law of this country ertitted to run the case as they think it fit. But they are supposed to take the instructions of their clien. very often the instructions of their client will come through the solicitor.. So what you try to do lis you tryt to find barristors who are prepared wo work with you. Occasionally you will find barristers who are prepaned to sake up a particularly political. line or have a particular viewpoint and you have to be very careful. In the Guildford case we had batristers who were very good, but who were intimidatad by the nature of the offence. And therefore were not prepared to be nobust, strong. They said to the police officers: "Yon hit him, didn't you?" And the police officers would say: "No we didn't'. And that was the sort of way it went on. There it is. It is diflicult. Barristers and solicitors ate a separate proflession in this country. But how much longer that may last well Id don"t know. At the moment of course there is a vested interest in keeping the profession separate because judges by and large, certainly judges of the supreme court in this country can only come from barristers. They can not come from solicitors. That is now changing as a result of new laws bringing in. But it will take a long. long time for a great change in attitude for barristers to think of solicitors as being equal in the fich for appointments to judges. Thope that gives you some idea of the situallion.

CR: Can miscarriages of justice still happen atter PACE?

AL: They can always happen, because there is still mo control over the power of the police. Let me tell you an interesting story. When they were dry-runnimg PACE, when they were testing it, they tested it in Scolland and $46 \%$ of all confessions that were made in offences when they were dryruming PACE occurred in places where there was no tape-recorder. So you get people going into an interview who wouldn't make any admission alt all and then the police officer would say: 'When I was driving him here in the motorcar to the police station, he suddenly said to me: "Alright Guxions 1 did in", or "When I was walking him down to his cell after he has beren in the interview during "which he mide no admission at all, he sudid, "Yeath, I did it, guv", that sort of things. And these things wete happening. It was quite clearly a police reaction. Pollicemen will find an easy way out' if they can, and a confession is an easy way out, lf you have a confescion you don't have to do really ans much work as youl have 10 do if you don't have a confession. So getting a confession is an easy way out for a police officer. You put that man away, and get on with an other job. And policemen took a long time to be convinced that this was not the right way in which it ig going to be. Pecause we uset to have what we calli verballing. Verballing was an expression an this country meaning the police would say that you said something which you deny. The onlly people who were: in the roon all the time were one police officer, or wo policeofficers and you. You are sitting there, you don"t have pencil and paper and when you get to court you suddenly find these two police officers are saying that you said something which you didn't say. It was a constant complaint. H almost every case, however small, however lange that the police had verballed. Then they started

1035. Dit is een Engelse standaard uiturukking gebruikt door de "lagere" sociale klasse wanneer iemand in een hogere positie aangesproken wordt. Het is aen affikonting voor govermor. Silang. 
introducing tape-recorders interviews. occurred in the police atation, in the interwitew. They all occurred outside. And the whole basis of having verbals thas now collapsed completely. And police officers are now finding themselves in the arrwelcome position that they camot mowe the goalposis and stack the oxds. So they could say somebody did it. But there are still an awfully lot of changes to need to be brought about. You tave to make sure that the care of preople in police stations is in the hands of people other than police. officers. We have a niake sure that we bring in video recorders. We have bo make sure that confessions can not be accepted unless they lake place wllen they are recorded and where all of the circumstances which cover those confessions are adequately recorded as well. That confessions without corroboration can newer be on the basis of the conviction. Those are changes which we need to bring about. There are also a lot of oher changes that need to be brought about in the appeal system. What the Gindford Four, the Maguire case and the Birmingham Six case demonstrated that the appeal cout was not prepared to admit that there has been made a mistake.

CR: The role of the Home Office in the Appeal procedure has been criticised. What do you think of the task of the Home Secretary in these cases?

$A L$ : He exercises this power to send it back to the court. Yes, that is a different set of circurrstances. Yes, it is true that there have been difficulties with that. But the difficulties are rather largely concerned with the fact that you are talking about civil serwants exercising a çuasi judicial function and we are not trained in this country for that. It may well be the continental systent which does have civill servarts whth legal training who carry out this sort of work. We don"t have that we have just ordinary civil serwants. They may have some knowledge, but they are not trained hawyers. And what was happening was, that the role that the Home Office saw itself playing in relation to cases like this. was that they were wailing for somebody to give them some evidence, and then when somebody gave them some evidence they would ask the policeforce who was responsible for the conviction originally. to get and look imo it. Anth that was siupid. If you ask the same people who got a vested interest in not doing anything, you will get the same answer. And that was the same with the Maguire case. When they asked the scientists to look into it, they asked the very sciertists who originally had done: the test. And they lied. You need to get an independent viewpoint. So there is no doubt that that will change now. We will end up in a situation where the Home Secretary is no longer going to have any kind of role like that. The executive arm of goverminent will not be responstble for deabing what is. essentially judicial. The judicial matter will go, I hope, to a new body, which will be an independent review body, that will judge miscarriages of justice cases.

CR: Can't the Police Complaints Authority do anything?

AL: It is toothless. It is not capable of dealing with determined police officters. The police are actually detemined that there should be no independent complaints body. But I don't think you will ever have aury public confidence in a system on investigation complains unless it is independent. Most of the statutory bodies mow that theal with the professions, that includes the law's societics have all independent persons who look into complaints and the police just have to go down that road, there is no choice about that. They are a powerful lobby. But the present Home Secretary is not particularIy keen to accept those sorts of arguments from the police. Maybe there will get some change. At the moment there is no change on the horizon, but it is something which is necessary.

CR: Should the police be more accountable?

All: Yess, because you give thern a great deal of power. Anybody who has power must be accoun table. Parents have power over their child, in the same way as the judge who was given power must tha accountable. The police officer, the doctor, anybody who was given that kind of power must have a system of accountability. Because if there isn't a system of accountability it leads to abuse. And very often ewan if there ism"t abuse there is an apparent perception that abuse may have occurred or may occur. And you aeed to give confidence to people. It is essential for policing that the comnunity sthould have confidence in the police. All that we have been talking about, sounds very negative, so fat as the police is concerned. But there sore some exceptional good and dedicated oflicers in the police force. "The anti-terrorist squad is as good, as one can reasonably expect them to be. There are people who have a great deal of concerns about the way in which the police should serve the public who ate now in the positions of authority. And things are changing. But whey don"t change quickly ethough and we do have that unfortunate system whereby pollicemen beget police, in other words we 
have what we call a cantern mentatioy. Once you are a police officer, you have to think like a police officer. And I believe that the policeforee should be radically altered, but we should have a fast track system in getting people: whth good gualifications and good minds into the policeforce at a rank with gives them the abilly to control and the ability to influence. Whereas the police mentality is that nobody should ever become a chief constable unless he first of all has been a constable on the beat. That is nonsense. You have fast trackers going into the army, in the armed services, you have fast trackers in the industry, why the hell shouldn't you have them in the police? But that kind of mentallisy which says that you are not a good policeman unless you worked your way up from the beat, is nonsense. Pollicing has changed. Those people who think that way, are the dinosaurs of the present time. But they aren't enough of them, unfortunately and that hasi to be changed. Untess you can change that, you will never get a change in philosophy. You have to stop that canteen mentality. That you defend your colleague at all costs, etc. etc. And once we have a policetorce which has got the confidence of the community, then we can start getting more justice in our society. The reality of the situation is that the policeforce which is discredited is incapable of providing protection for ethic minorities, sexual discrimination, child abuse, because they are not seen in that role, because they are not trusted in that role. And these cases have done an incredable amount of damage to the way in which the public perceive the police. If those officers are convicted, that are on trial at the Old Bailey, the probable explanation will be that the jury no longer betieve what police officers have to say. And they have only themselves to blame for that, because they produced that simation. Butt those of us who have a concern about our communiry functions, how out conmunity must be regulated. those of us who have a concern about the rule of law have to be concermed about the way in which the police are viewed in the community. Because they are an essential part of the management structure of our society. We cannot manage without a policeforce. Whatever you call it, it still got to be there. Because there are criminals in our society who cause misery and danage to other people. They have to be controlled. We have to delegate our responsibility to police officers in order to make sure that the laws are abeyed.

CR: Would it be possible to ask questions to some of the Guildford people?

AL: You can do. I only act for two of the Guildford Four. And I do act for all of the Maguire Six who are alive. One of the Maguire Seven died, which was Guiseppe. The problem is that many of them atre trying to put these things behind them. Some of them have quite considetable difficulties caused by long periods of time in prison. Schizophrenia in one case, severe depressions. And I don't know what kinds of results 1 get, but $I^{2} \| 1$ do the best I can. I can't force them to do it, and you wouldn"t want me to do that. But I lawe to tell you that some of them may well say it is something they don't want to be troubled with. They are not people who are crusaders basically. I mean the Gerry Conlons of this world.

CR: He has written a book.

AL: Trial and Error was written by Robert Kee. Conton called wis book "Proved Innocent". I don't think you will find that he wrote that book. I think you will find that it was written by someone else, a joumalist. Yes. Unfortunately. there are a lot of things that mr. Conton does, but thete are some doubs as to the ability to retain the reality. There are certain things in that book that sterr from complete inagination. Yes, there are some crusaders, but all the other ones like Carole Richardson, who is married, has a baly, and all she wants to do is be an ordinary, boring suburban housewife, that is what she has been waiting for all those years. She has gou it now and she has not the remotest intention to giving it up.

They do want to help. As long as you understand that you will get some answers from one of two and perhaps not from the rest.

CR: Do you know other cases as well?

AL: There are a number of other ones that are miscarriages. But there are no note Irish terrorist cases. Everybody else who lias been caugh and put into prison and they werent put into prison for the right thing, certainly they were put into prison bectatse they were doing something that they were not supposed to be dong. There are a number of other bight profile cases, where there ane serous concerns. Perluaps the besi knowr one is the Carl Bridgewater case, where a young boy aged 
10 or 11 10w was klled with a shotgun while the was bringing newspapers to al deserted farmhouse which was in fact being used by criminals who just carried out a successfull burglary. They thought he was somebody else and they shot him. The people who were convicted of dhat offence protested their innocence. So that is one case that cerdainly has a very high profile. ${ }^{1037}$ There are a number of other cases: two sisters who are currenty in jail for having killed what was alleged to have been the girlfriend of one of the sister"s boyfriend. They hawe protested their innocence and there is quite a lot of suppont for them. There are four people in North Ireland - four protestants - who are convicted of an offence which there is widespread belief they lnadn't done it. But by and large we haven't got that many cases, whe don't have a huge great storm of cases which are gaing to go. A lot of cases of course don't inwolve people who are serwing sentences any longer. I still receive quite a lok of communications from people who were convieted of offences many yeass ago, have been to prison, served the sib sentences, left prison and now say car Ilook again in the case for I wasn"t guily in that offence. It is very, very dificult to get this sort of cases reopened. There is no urgency, there is no willingress 0 open those cases. I have a man who is serving a wery lengthy sentence in a fremch prison $_{\text {. }}$ ho was convicted of a firearms-offence in this country in 1963. He says: "I never did it. I always told everyone I never did it". But of coumse nobody is really interested.

1036. De jongen Carl Bridgewater was 13 jaar en werd in 1978 vermoord op een boerderij in Statfordshite. Rozenburg, 1992, p. 111 .

1037. Agenter van de Hest Mullands Seriows Crime Squad hadden de verdachten ondervragd. De Serions Crime Squad is later opgedoekt vanwege de werschillende mascarriages of justice. Zie ook Rozenburg, 1992, p. 111. 


\section{Literatuurlijst}

Albert, Hubert-Ian, De ongelijkzijdige driehoek, 1994, Gouda Quint BV, Arnhem.

Andersson, Elffers en Felix, Rijksrecherche, onderzoek naar huidige en toekomstige organisatie van de dienst, 1993, juli, Utrecht.

Annual Report of the Police Complaints Authority 1989, 1990,2 May, HMSO, London.

Ascoli, David, The Queen's Peace, 1979, Hamish Hamilton, London.

Ashworth, Andrew, 'From Policing to Prosecutions' (editorial), The Criminal Law Review, 1985, p. 1-3.

Baldwin, Robert, en Richard Kinsey, Police Powers and Politics, 1982 , Quartet Books, London.

Barker, T. en D. Carter, 'Fluffing up the evidence and covering your ass: some conceptual notes on police lying', Deviant Behawiour, II, 1990, p. $61-73$.

Becker, H.S., Outsiders: Studies in the Soctology of Deviance, 1963. Free Press, New York.

Bell, John, "Police and Accountability", Local Govermment Studies, 1989. January/February, p. 57-69.

Bemmelen, J.M. van, en Th. W. van Veen, Strafprocesrecht, 1989, Samsom H.D. Tjeenk Willink, Alphen aan den Rijn.

Bennion, Francis, "The Crown Prosecution Service", The Criminal Law Review, 1986, p. 3-15.

Bennett, Ronan, 'Criminal Justice', London Review of Books, 1993, 24 June, p. 3, 5-15.

Beryon, John and Colin Bourn, The Police: Powers, Procedures and Proprieties 1986, Pergamon Press, Oxford.

Beryon, John, "Policing in the limelight: citizens, constables and controversy", in: Benyon, John and Colin Bourn, The Police: Powers, Procedures and Proprieties, 1986, Pergamon Press, Oxford, p. 3-42. 
Benyon, John, 'The Policing Issues', im: Benyon, John, (ed), Scarman and After, 1984, Pergamon Press, Oxford, p. 100.

Benyon, John, Lynne Turnbull, Andrew Willis, Rachel Woodward, Adrian Beck, Police Co-operation in Europe: an investigation, 1993, November, University of Leicester.

Berry, Geoff, Jim Izat, Rob Mawby en Lynne Walley, Practical Police Management, 1995, Police Review Publishing Co Ltd, Oxford.

Bevan, Vaughan en Ken Lidstone, A Guide to the Police and Criminal Evidence Act 1984, 1985, Butterworths, London.

Bijzondere Onderzoekscommissie IRT (Commissie Wierenga), Rapport, 1994, Ministerie van Binnenlandse Zaken, Den Haag.

Blaauw, J.A., 'Een corrupte diender is de pest voor het hele korps', Justitiële Verkenningen, 1991, jrg. 17, nr. 4, p. 33-52.

Black, Donald, The Manners and Customs of the Police, 1980, Academic Press, New York.

Boek, J.L.M., Organisatie, functie en bevoegdheden vam politie in Nederland, 1995, Gouda Quint BV, Arnhem.

Boerstra, Evert, 'Een wat orthodox rapport met een hoog schuld en boete-gehalte", Algemeen Politieblad, 1996, 17 februari, nr. 4, p. 4-5.

Bond, Kevin, 'The Case for a National Force', Policing, 1988, 4, p. 293-308.

Bos, Ilse, "De gereorganiseerde politie: "Olympisch turnen in een harnas" "Binnenlands Bestuur, 1994, 3 juni $^{,} 21-22$, p. 28-33.

Bosch, M., 'Klachtafhandeling bij politie-optreden", in: Almelo, A.E. van en P.G. Wiewel, Politiezorg in de jaren '90, 1991, Gouda Quint BV, Arihem, p. 69-98.

Braithwaite, John, Corporate Crime in the Pharmaceutical Industry, 1984, Routledge \& Kegan Paul, London.

Brants, Chr., "The Royal Commission on Criminal Justice, Meer van hetzelfde in de Engelse strafprocedure', Delikt en Delinkwent, 24, 1994, p. $28-40$. 
Bridges, Lee en Mike McConville, 'Keeping faith with their own Convictions: The Royal Commission on Criminal Justice', in:

McConville, Mike en Lee Bridges, Criminal Justice in Crisis, 1994, Edward Elgar, Hants, p. 3-23.

Brogden, Michael, The Police: Autonomy and Consent, 1982, Academic Press, London.

Brown, David, The Police Complaints Procedure: A Survey of Complainants' Views, 1987, HORS no. 93, HMSO, London.

Brown, David, Investigating Burglary: The Effects of PACE, 1991, HORS no. 123, HMSO, London.

Bruinsma, Gerben J.N., 'De reorganisatie van de politie en de kwaliteit van politiezorg', Tijdschrift voor de Criminologie, 1994, 4, p. 368-381.

Bruyne, Marnix de, 'Britse politie is verrot', De Krant op Zondag, 1991, 10 maart, p. 13.

Bunyard, R.S., Police: Organisation and Command, 1978, Macdonald and Evans, Estover, Plymouth.

Cachet, A., 'Reorganisatie van het politiebestel: een onverwacht succes?', NAMENS, 1991, jrg. 6, afl. 4, p. 4-12.

Cachet, A. en U. Rosenthal, 'Reorganisatie van de politie: een tussenbalans', in: Cachet, A. en U. Rosenthal, Reorganisatie van de politie: een tussenbalans, 1992, Gouda Quint BV, Arnhem, p. 13-26.

Cachet, Lex, Arie van Sluis, Edward van der Torre, "Reorganisatie van de politie, onderzoek, beleid en verandering', Tijdschrift voor de Criminologie, 1993, nr. 1, p. 11-26.

Cachet, L., A. van Sluis, E.J. van der Torre, U. Rosenthal en E.M. Muller, 'Een nieuwe Politiewet, maar geen nieuw begin', Justitiële Verkenningen, 1993, jrg. 19, nr. 4, p. 37-68.

Cachet, A., 'Reorganisatie van de politie: verrassend, imponerend en verontrustend', Openbaar Bestuur, 1993, 11, p. 22-27.

Card, Richard, 'Police Accountability and Control over the Police', Bramshill Journal, 1979, p. 9-14. 
Claylon, Richard, Hugh Tomlinson, Civil Actions Against the Police, 1987. Sweet \& Maxwell, London.

'Code for Prosecutors', Law Society's Gazette, 1986, 23 July, p. 2308.

Coleman, Clive, David Dixon en Keith Bottomley, 'Police Investigative Procedures: Researching the Impact of PACE', in: Walker, Clive en Keir Starmer, Justice in Error, 1993, Blackstone Press Limited, London, p. $17-31$

Commissie Hoofdstructuur Rijksdienst, (Commissie Vonhoff), Eindadvies, 1981, 25 mei, Ministerie van Binnenlandse Zaken.

Commissie van Onderzoek Amsterdam, Eerste interim-rappont, 1967, Staatsuitgeverij, 's-Gravenhage.

Commissie van Onderzoek Amsterdam, Tweede interim-rapport, 1967. Staatsuitgeverij, 's-Gravenhage.

Commissie van Onderzoek Amsterdam, Slotrapport, 1967, Staatsuitgeverij, 's-Gravenhage.

Community/Police Consultative Group for Lambeth, The Brixton Disorders of 1985, 1986, July, London.

'Confait: a purpose built case for the Royal Commission?', Police: The Monthly Magazine of the Police Federation, 1978, January, p. 16.

Cooper, Jeremy, 'Criminal investigations in France', New Law Journal, 1991. March 22, p. 381-382.

Corstens, G.J.M., Het Nederlandse strafprocesrecht, 1993, Gouda Quint BV, Arnhem.

Cowell, David, Trevor Jones en Jock Young, Policing the Riots, 1982 , Junction Books, London.

CPS, Annwal Report 1990-1991, 1991, London.

Critchley, T.A., A History of Police in England and Wales, 1979, Constable, London.

Crisis Onderzoek Team, Politiebestel in verandering: Verhoudingen tussen politie, bestuu, justitie en gemeenteraad onder de oude en de nietrive Politiewet, 1994, Gouda Quint BV, Arnhem. 
Crombag, H.F.M., P.J. van Koppen en W.A. Wagenaar, Dubieuse Zaken: de psychologie van strafrechtelijk bewijs, 1992, Contact, Amsterdam.

Daalen, Jan van, Sars Rancune, Een Schokkend Relaas, 1991, De Boekerij, Amsterdam.

Damaška, Mirjan $\mathbb{R}$. "The Faces of Justice and Siate Authority, 1986, Yale university Press, New Haven.

Doelder, H. de, 'Opinie: Het OM afgedreven', NJB, 1994, 22 aprill, aff. 16.

Drenth, J.H., Bijdrage tot de kennis der historische ontwikkeling wan het accusatoire tot het inquisitoire strafproces, 1939, Noord-Hollandsche Uitg. Mij, Amsterdam.

Editorial, 'Miscarriages of Justice Again", Criminal Law Review, 1990 , p. 613-614.

Editorial, 'Royal Commission on Criminal Justice", Criminal Law Review, 1991, p. 489-490.

Editorial, 'Unappealing'. New Law Journal, 1991, March 22, p. 373.

Elzinga, D.J., 'Een volle ministeriële verantwoordelijkheid woor het Openbaar Ministerie', NJB, 1994, 22 april, afl. 16, p. 529-537.

Elzinga, D.J., P.H.S. van Rest en J. de Valk, Het Nederlandse Politierecht, 1995, W.E.J. Tjeenk Willink, Zwolle.

Elzinga, D.J., "Verantwoordelijkheid en aanspreekbaarheid in de verhouding tussen bestuur, Openbaar Ministerie en politie", RM Themis, 1996,6, p. $205-214$

Emsley, Clive, Crime and Society in England, 1750-1900, 1987 , Longman, London.

Emsley, Clive, The English Police, A Political and Social History, 1991, Harvester Wheatsheaf, Hemel Hempstead.

Emsley, Clive, "The History of Crime and Crime Control Institutions" in: Maguire, Mike, Rod Morgan and Robert Reiner, The Oxford Handbook of Criminology, 1994, Clarendon Press, Oxford, p. 149-182. 
Enright, Seằn, 'Cost effective criminal justice", New Law Joumal, 1993, July 16, p. 1023-1024.

Fasseur, C., 'Het nieuwe politiebestel, Enkele kanttekeningen bij de Politiewet 1993; $N$ NB, 1994, afl. 12, 25 maart, p. 391-397.

Fijnaut, Cyrille, Opdat de macht een toevlucht zij?, 1979, Kluwer, Antwerpen.

Fijnaut, C., 'De koninklijke marechaussee oftewel de onvoltooide reorganisatie van het politiebestel', Delikt en Delinkwent, 1994, 24, aft. 10 , p. $998-1006$.

Fine, Bob, Robert Millar, Introduction: The Law of the Market and the Rule of Law, in: Fine, Bob, Robert Millar, Policing the Miners' Strike 1985, Lawrence \& Wishart, London, p. 5.

Fine, Bob, Robert Millar, Policing the Miners' Strike 1985, Lawrence \& Wishart, London.

Fisher, Sir Henry, Report of an Inquiry by the Hon. Sir Henry Fisher into the circumstances leading to the trial of three persons on charges arising out of the death of Maxwell Confait and the fire at 27 Doggett Road, London SE6, 1977, HMSO, London.

'The Fisher report' (editorial), The Criminal Law Review', 1978, March, p. 117-121.

Foot, Paul, 'Still it goes on', London Review' of Books, 1993, 4 November, p. 11-12.

Forder, Catoline en Elies Steyger, 'De Birmingham Six: een juridische horrorstory', $N J B, 1991,27$ juni, aff. 26, p. 1050-1055.

Freeman, M.D.A., The Police and Criminal Evidence Act 1984, 1985, Sweet \& Maxwell, London.

Gandy, David, 'The Crown Prosecution Service: its organisation and philosophy", in: J.E. Hall Williams, The role of the prosecutor, 1988 , Avebury, Aldershot, p.7-18.

Gardiner, J., The Poltics of Corruption, 1970, Russell Sage Foundation, New York. 
Goldsmith, Andrew J., 'Introduction", in: Andrew J. Goldsmith (ed), Complaints against the Police, The Trend to Extemal Review, 1991, Clarendon Press, Oxford.

Goodhart, A.L., 'Memorandum of Dissent', Final Report, Royal Commission on the Police, 1962, HMSO, Cmnd 1728, London.

Goudriaan, René, Frank van Tulder, Jos Blank, Ab van der Torre, Bob Kuhry, Doelmatig Dienstverlenen, 1989, Sociaal en Cultureel Planbureau, Rijswijk.

Greater London Council Police Committee Discussion Paper no. 1, A New Police Authority for London, A consultation paper on democratic control of the police in London, 1983, s.1.

Guijt, J.D.C., 'Rijksrecherche in Nederland', in: Tijdschrift voor de Politie, 1989, (51), aug/sept, nr. 8/9, p. 383-386.

Hall, Stuart, Chas Critcher, Tony Jefferson, John Clarke, and Brian Roberts, Policing the Crisis, Mugging, the State, and Law and Order, 1978, Holmes \& Meier Publishers, New York.

Hall Williams, J.E., 'Overall conclusions and lessons learned", in: J.E. Hall Williams, The Role of the Prosecutor, 1988, Avebury, Aldershot, p. 104-107.

Harlow, Carol, Richard Rawlings, Law and Administration, 1984, Weidenfeld and Nicolson, London.

Harrison, John, Police Misconduct: Legal Remedies, 1987, Legal Action Group.

Hendriks, L.E.M., J.H. Klifman, G.P.M.F. Mols, Th.A. de Roos, J. Wöretshofer, Hoofdstukken Strafprocesrecht, 1992, Samsom H.D. Tjeenk Willink, Alphen aan den Rijn.

Heuvel, G.A.A.J. van den, Onderhandelen of straffen: over organisatiecriminaliteit en overheidscontrole, 1993, Gouda Quint, Arnhem.

Hibbert, Christopher, King Mob, The Story of Lord George Gordon and the Riots of 1780,1958 , Longmans, Green and Co Lid, London.

Hill, Michael, "The Criminal Bar and the prosecution service', in" John Benyon and Colin Bourn, The Police: Powers, Procedures and

Proprieties, 1986, Pergamon Press, Oxford, p. 237-242. 
Hilliard, Brian, 'Blessed with Hindsight', New Law Journal, 1991, March 22, p. 393.

Hilliard, Brian, 'Dona Ferentis', New Law Journal, 1993, July 16, p. 1036.

Hillyard, Paddy, "The Politics of Criminal Injustice: The Irish dimension', in: McConville, Mike en Lee Bridges, Criminal Justice in Crisis, 1994, Edward Elgar, Hants, p. 69-79.

Höfte, C.E.M.G., 'De reorganisatie van de politie: waar zijn we nu?', Justitielle Verkenningen, 1993, jrg. 19, nr. 4, p. 91-99.

Holdaway, Simon, (ed), The British Police, 1979, Arnold, London.

Hutton, Will, The State We're In, 1995, Jonathan Cape, London.

The Independent, 1993, 20 May, p. 1, 2, 25.

James, Leslie, 'Police accountability', Justice of the Peace, 1980, March 22 , vol. 144, p. $169-171$.

Jefferson, Tony, The Case against paramilitary policing, 1990, Open University Press, Milton Keynes.

Jefferson, Tony, en Roger Grimshaw, 'Law, Democracy and Justice', in: Cowell, David, Trevor Jones en Jock Young, Policing the Riots, 1982, Junction Books, London.

Jörg, N, en C. Kelk, Strafrecht met mate, 1994, Gouda Quint BV, Arnhem.

Judge, Tony, "The politics of the police', Policing, 1985, p. 302-309.

JUSTICE, Miscarriages of Justice, 1989, London.

Kee, Robert, Trial and Error, 1986, Hamish Hamilton, London.

Kelley, Kevin, The Longest War. Northern Ireland and the IRA, 1982, Brandon, Ireland.

Knigge, G., 'Van Traa en werder', RM Themis, 1996, 6, p. 203-204.

Koers, J., 'Fraudebestrijding in Engeland', Justitielle Verkenningen, 1988, jrg. 14, nt. 1, p. 79-112. 
Koppenjan, J.F.M., A.B. Ringeling en R.H.A. te Velde, Beleidsworming in Nederland: een vergelijkende studie naar de totstandkoming van wetten, 1987, VUGA, 's-Gravenhage.

Lacey, Nicola, Missing the Wood ... Pragmatism versus Theory in the Royal Commission', in: McConville, Mike en Lee Bridges, Criminal Justice in Crisis, 1994, Edward Elgar, Hants, p. 30-41.

Lambert, John L., Police Powers and Accountability, 1986, Croom Helm, London.

Lea, John, en Jock Young, "The Riots in Britain 1981: Urban Violence and Political Marginalisation', in. David Cowell, Trevor Jones en Jock Young, Policing the Riots, 1982, Junction Books, London.

Leijten, J., 'Onze les uit de Zes van Birmingham", NRC Handelsblad, 1991, 22 maart.

Lensing, J.A.W., "Van "miscarriages of justice" en de PACE', Delikt en Delinkwent, 1991, 21, p. 1048-1077.

Lensing, J.A.W., "Herijking van strafprocesrecht op zijn Engels', Delikt en Delinkwent, 1994, 24, afl. 6, p. 568-593.

Lloyd, Cathie, A National Riot Police." Britain's 'Third Force'?, in: Fine, Bob, en Robert Millar, Policing the Miners" Strike, 1985, Lawrence \& Wishart, London, p. 65-68.

Logan, Alastair, 'A sewer runs through it", London Review of Books, 1993, 4 November, p. 9-10.

Lustgarten, Laurence, The Governance of Police, 1986, Sweet \& Maxwell, London.

Maas, Peter, Serpico, 1973, The Viking Press, New York.

Mackenzie, John, 'The Royal commission on what?', New Law Joumal, 1993, July 16, p. 1035.

Maguire, M. and C. Corbett, A Study of the Police Complaints System, 1991, HMSO, London.

Malleson, Kate, Miscarriages of Justice and the Accessibility of the Court of Appeal', Criminal Law Review, 1991, p. 323-332. 
Marchand, M. en B. Wennekendonk, De relatie Politie-Rijksrecherche, 1990 , J.B. van den Brink \& $\mathrm{Co}$, Lochem.

Marchand, M.Th. M. en B.G. Wernekendonk, 'Alles wat je zegt...!" in: Justitiele Verkenningen, 1991 , jrg. 17, nr. 4, p. 75-98.

Mark, Robert, Policing a perplexed society, 1977, Allen and Unwin, London.

Marnoch, Alexander, Repont on the Brixton Disorders 28/29 September 1985, Metropolitan Police, Lambeth Community/Police Consultative Group, 1985, 8th October.

Marshall, Geoffrey, Police and government: The status and" accountability of the English constable, 1965, Butler and Tanner Ltd, London.

May, Erskine, Parliamentary practice; Treatise on the law, privileges, proceedings and usage of Parliament, (editor: Sir Charles Gordon), 16th edition, Butterworths, London.

May, Erskine, Parliamentary practice; Treatise on the law, privileges, proceedings and usage of Parliament, (editor: Sir Charles Gordon), 1983, 20th edition, Butterworths, London.

McCabe, Sarah, Peter Wallington, The Police, Public Order, and Civil Liberties: Legacies of the Miners' Strike, 1988, Routledge, London.

McConville, Mike and Chester Mirsky, The disordening of criminal justice, New Law Journal, 1993, October 15, p. 1446-1447.

McConville, Mike en Lee Bridges, Criminal Justice in Crisis, 1994, Edward Elgar, Hants.

McElree, Fiona en Keir Starmer, 'The Right to Silence', in: Walker, Clive en Keir Starmer, Justice in Error, 1993, Blackstone Press Limited, London, p. 58-74.

Melai, onder redactie van Groenhuijsen, M.S., Th. A. De Roos en A.H.J. Swart, Hetboek van Strafioordering, art. 29, aant. 2.

Melville Lee, W.L., A History of Folice in England, 1971, Patterson Smith, (oorspronkelijk gepubliceerd in 1901 door Methuen \& Co), London. 
Merricks, Walter, "An independent prosecution service: principles and practice", in: John Benyon and Colin Bourn. The Police: Powers,

Procedures and Proprieties, 1986, Pergamon Press, Oxford, p. 243-250.

Middelburg, Bart en Kurt van Es, Operatie Delta, Hoe de drugsmafia her IRT opblies, 1994, L.J.Veen.

'Moet Justitie blijven?', $N I B, 1996,27$ september, afl. 34, p. 1401-1410.

Mols, G.P.M.F., Th.A. de Roos en T. Spronken, "Het echte IRT-debat, Grenzen van opsporingsmethoden', NJB, 1994, 17 juni, afl. 24.

Morgan, Jane, Confict and Order, 1987, Clarendon Press, Oxford.

Morgan, Rod, 'Policing by consent:legitimating the doctrine', in:

Morgan, Rod, David J. Smith, Coming to Terms with Policing, 1989 , Routledge, London, p. 217-218.

Morgan, Rod, David J. Smith, Coming to Terms with Policing, 1989 , Routledge, London.

Mullin, Chris, Error of Judgement, The Truth about the Birmingham Bombings, 1990, Poolbeg, Dublin.

Naeyé, Jan, Het politieel vooronderzoek in strafzaken, Over sturing en toetsing wan de pro-actieve opsporing, 1995, Gouda Quint, Arnhem.

Naeyé, J. en T.M. Schalken, 'Commissie-Van Traa en de crisis in de opsporing', NJB, 1996, 9 februari, p. 197-205.

Niemantsverdriet, Hans, 'Hadden we ze maar opgehangen", Intermediair, 1991,26 april, p. 17, 19, 21 .

Nijboer, J.F., "The American adversarial system in criminal cases", in: Recht en kritiek, 1992, 18, 1, p. 8-26.

Nobles, Richard en David Schiff, "Optimism Writ Large: A Critique of the Runciman Commission on Criminal Justice", in: McCorville, Mike en Lee Bridges, Criminal Justice in Crisis, 1994. Edward Elgar, Hants, p. $42-50$.

O'Beirne Ranelagh, John, A Shont History of Ireland, 1983, Cambridge University Press, Cambridge. 
O'Connor, Patrick, "The Court of Appeal: Re-Trials and Tribulations", Criminal Law Review, 1990, p. 615-628.

Oliver, lan, Police, Govermment and Accountability, 1987, Macmillan, London.

'Opheffing IRT hield geen verband met corruptie', Algemeen Politieblad, 1994,5 februari, nr. 3 , p. $4-6$.

Oudheusden, H.K.A. van, 'Regionaliseren bij de politie: de kunst wan het doen', Tijdschrift roor de Politie, 1993, april, nr. 4, p. 91-95.

Outrive, L. van, 'Bestuurlijke en gerechtelijke controle over de politie in Nederland", in Bianchi, H., H.A. Diederiks, A. Mulder, R.W. Jongman, L. wan Outrive, D.W. Steenhuis, B. de Gaay Fortman, Tussen misdaad en straf, 1981, Intro, Nijkerk, p. 71-99.

Oxford, Kenneth, 'Policing by consent', in: John Benyon, (ed), Scarman and After, 1984, Pergamon Press, Oxford.

Packer, H.L., The Limits of the Criminal Sanction, 1968, Stanford University Press, Stanlord.

Padfield, Nicola, 'The Dissenting voice', New Law Journal, 1993, July 16 , p. $1022-1023$.

Parren, H.F.H., 'Politiecorruptie en bestrijding ervan', in: Tijdschrift voor de Politie, 1989, (51), april, nr. 4, p. 156-160.

Perrick, F, Politie in Nederland, een inleiding tot haar geschiedenis, organisatie en taak, 1982, W. E..J. Tjeenk Willink, Zwolle.

Pike, Michael S., Principles of Policing, 1985, Macmillan Press Ltd, London.

Police Complaints Authority, Triennial Review 1988-1991, 1991, HMSO, London.

Police Complaints Authority, Annual Report: I January to 31 December 1989, 1990, HMSO, London.

Police Complaints Authority, Annual Report: I January to 31 December 1991, 1992. HMSO, London.

'De Politie in Engeland', Tyjdschrift voor de Politie, 1989, p. 320-323. 
Portegies-Damave, M.E., "Een nieuwe politiewet", Ars Aequi, 1994, 43, $7 / 8$, p. 512-519.

Price, Christopher, 'Open Letter to Sir Henry Fisher', New Statesman, 1978,6 January, p. 10-11.

Pringle, Patrick, in Goddard, Henry, Criminele Recherche, meer dan honderd jaar geleden, 1957 "H.D. Tjeenk Willink \& Zoon N.V., Haarlem, p. 9-34.

'Prosecution and Offences Act 1985', The Law Society's Gazette, 1986, 9 April, p. 1029.

Punch, M., Policing the Inner City, 1979 (A), Macmillan, London.

Punch, Maurice, 'The Secret Social Service', in: Holdaway, Simon, The British Police, 1979 (B), Edward Arnold, London.

Punch, Maurice, "When the wheel comes off: reactions to police deviance in Amsterdam', in: Clarke, Michael, Corruption, Causes, Consequences and Control, 1983 (A), Frances Pinter (Publishers) Ltd, London, p. 111-118, 119 .

Punch, Maurice, 'Officers and Men: Occupational Culture, Inter-Rank Antagonism, and the Investigation of Corruption", in: Punch, Maurice, (ed), Control in the Police Organization, 1983 (B), MIT Press, Cambridge, Mass., p. 227-250.

Punch, Maurice (ed), Control in the Police Organization, 1983 (C), MIT Press, Cambridge, Mass.

Punch, Maurice, Conduct Unbecoming. The Social Construction of Police Deviance and Control, 1985, Tavistock Publications, London.

Rattner, Arye, "Convicted but Innocent: Wrongful Conviction and the Criminal Justice System', Law and Human Behavior, 1988, 12, p. 283293.

Redactie, 'De nasleep van het IRT-debat, Algemeen Politieblad, 1994, 30 april, nr. 9, p. 12-13.

Redactie, 'Opsporingsmethoden in discussie', Algemeen Dagblad, 1994, 12 november, nr. 22, p. 4, 19. 
Redactie, 'Plan van Aanpak na Van Traa', Algemeen Politieblad, 1996, 12 oktober, nr. 20 , p. $8-9$.

Redactie, 'Nuanceverschillen tussen Kabinet en Kamer', Algemeen Politieblad, 1996, 25 mei, nr. 22, p. 12-13.

Redactioneel, "De pijn van veranderen", Tijdschrift voor de Politie, 1992 , p. 437 .

Redactioneel, 'Eén politie: 27 korpsen', Tijdschrift voor de Politie. 1993. september, p. 249.

Redactioneel, "Verzelfstandiging van de politie?', Tijdschrift woor de Politie, 1993, oktober, p. 289.

Reenen, P. van, Overheidsgeweld, een sociologische studie van de dynamiek van het geweldsmonopolie, 1979, Samson, Alphen aan den Rijn.

Reenen, P. wan, 'Het zwevende politiebestel', Justitiële Verkenningen, jrg. 19, nr. 4, 1993, p. 7-36.

Reenen, Piet van, 'Geef de pollitie de ruimte? Bevoegdheden en effectieve criminaliteitsbestrijding', Tijdschrift voor de Criminologie, 1994, 4, p. $351-367$.

Reiner, Robert, "Police Unionism", in: Holdaway, Simon, (ed), The British Police, 1979, Arnold, London.

Reiner, Robert "The Politics of the Police, 1985, Wheatsheaf Books, Sussex.

Reiner, Robert, 'Policing and the Police' in: Maguire, Mike, Rod Morgan and Robert Reiner. The Oxford Handbook of Criminology, 1994, Clarendon Press, Oxford, p. 705-772.

Reiner, Robert, "The Perfidy of the Paramour', Times Literary Supplement, 1995, september 1, p. 9-10.

Reisman, W. Michael, Folded Lies, 1979, Free Press, New York.

Reiss, Albert $J$., 'Selecting strategies of social control over organizational life', in: Hawkins, $\mathbb{K}$. en J.M. Thomas, Enforcing Regulation, 1984, Kluwer Nijhoff, Boston, p. 23-35. 
Reiss, Albert, J., Jr, "The Policing of Organizational Life" in Punch, Maurice (ed), Control in the Police Organization, 1983, MIT Press, Cambridge, Mass., p. 78-97.

Roording, J., 'Magistraat in Engeland', Delikt en Delinkwent, 1996, 26, afl. 1, p. 23-39.

Roos, Theo de, 'Opinie: Rapportage commissie Wierenga: unfair, cenzijdig, onvolledig', $N J B, 1994,1$ april, afl. 13, p. 438-439.

Rose, David, In the Name of the Law, the Collapse of Criminal Justice, 1996, Jonathan Cape, London.

Rosenthal, U., 'Wachten op de Politiewet', in: Koppenjan, J.F.M., A.B. Ringeling en R.H.A. te Velde, Beleidsworming in Nederland: een vergelijkende studie naar de totstandkoming wan wetten, 1987, VUGA, 's-Gravenhage, p. 225-242.

Royal Commission on Criminal Procedure 1981, Report, 1981, HMSO, Cmnd 8092, London.

Royal Commission on Criminal Justice, Report, 1993, Cm. 2236 , HMSO, London.

'Royal Commission on Criminal Justice', The Criminal Law Review, 1991 , p. $489-491$.

Royal Commission on Criminal Justice, 'Royal Commission on Criminal Justice invites written evidence', Press Release, 1991, 14 June.

Royal Commission on Criminal Justice, "Royal Commission on Criminal Justice sets up research programme', Press Release, 1991, 29 November.

Royal Commission on the Police, Final Report, 1962, HMSO, Cmnd 1728, London.

Rozenburg, Joshua, 'Miscarriages of Justice', in: Stockdale, Eric and Silvia Casale, Criminal Justice under stress, 1992, Blackstone Press Limited, London.

Samuels, Alec, 'Non-Crown Prosecutions: Prosecutions by Non-Police Agencies and by Private Individuals', The Criminal Law Review, 1986, p. $33-44$. 
Sanders, Andrew, 'Prosecution Decisions and the Attorney-General's Guidelines', The Criminal Law Review, 1985, p. 4-19.

Sanders, Andrew, 'An Independent Crown Prosecution Service?', The Criminal Law Review, 1986, p. 16-27.

Sanders, Andrew, "Incorporating the "public interest" in the decision to prosecute", in: J.E. Hall Williams, The Role of the Prosecutor, 1988, Avebury, Aldershot, p. 30-42.

Sanders, Andrew en Lee Bridges, 'The Right to Legal Advice' in: Walker, Clive en Keir Starmer, Justice in Error, 1993, Blackstone Press Limited, London, p. 37-54.

Sanders, Andrew, 'From Suspect to Trial', in: Maguire, Mike, Rod Morgan and Robert Reiner, The Oxford Handbook of Criminology, 1994, Clarendon Press, Oxford, p. 773-818.

Scarman, Lord Justice, The Red Lion Square Disorders of 15 June 1974, 1975, HMSO, London.

Scarman, The Rt. Hon. Lord, The Brixton Disorders, 1981, HMSO, Cmnd 8427, London.

Scarman, Lord, The Scarman Report, The Brixton Disorders 10-12 April 1981, 1986, Penguin, Harmondsworth.

Schalken, T.M., 'Het taboe van art. 5 RO', Trema, 1991, p. 179-194.

Schalken, T.M., 'Controle op de politie', Delikt en Delinkwent, 1994 , 24, afl. 10, p. 993-997.

Schuyt, C.J.M., Tussen macht en moraal, 1983, Samsom, Alphen aan den Rijn.

Scraton, Phil, The State of the Police, 1985, Pluto Press, London.

Sedley, Stephen, 'Whose Justice?', London Review of Books, 1993, 23 September, p. 3, 6.

Selznick, Philip, Leadership in Administration, 1957, Harper \& Row, Berkeley, p. 53-55. 
Sherman, Lawrence W. 'The sociology and the social reform of the american police: 1950-1973', Joumal of Police Science and Administration, 1974, Volume 2, no. 3, p. $255-262$.

Sherman, Lawrence W., Scandal and Reform, Controlling Police Corruption, 1978, University of California Press, Berkeley,

Sherman, Lawrence W., "Causes of Police Behavior: The current state of quantitative research', Joumal of research in crime and delinquency, 1980 , January, p. 69-99.

Sherman, Lawrence W. 'Reducing Police Gun Use: Critical Events, Administrative Policy, and Organizational Change', in: Maurice Punch (ed), Control in the Police Organization, 1983, The MIT Press, Cambridge, Massachusetts, p. 98-125.

Sieghart, Paul, 'Reliable evidence, fairly obtained', in: John Benyon and Colin, Boum, The Police: Powers, Procedures and Proprieties, 1986 , Pergamon Press, Oxford, p. 268-278.

Sieghart, Paul, 'A view from JUSTICE', in: J.E. Hall Williams, The Role of the Prosecutor, 1988, Avebury, Aldershot, p. 95-103.

Skolnick, Jerome H., Justice without Trial: Law Enforcement in Democratic Society, 1975, second edition, John Wiley, New York.

Southgate, Peter, Peter Ekblom, Contacts between Police and Public, 1984, HORS na. 77, HMSO, London.

Sprack, John, 'The Trial Process", in: Stockdale, Eric and Silvia Casale, Criminal Justice under stress, 1992. Blackstone Press Limited, London.

Staal, B., "Politie en politiek in driehoeksoverleg. een polemische bijdrage", in: Rosenthal, U., P. "t Hart en A. Cachet, Politie-

management: een politiek-bestuarlijke visie, 1987, Gouda Quint, Arnhem.

Stead, Philip John, The Police of Britain, 1985, Macmillan, London.

Stichting Maatschappij en Politie, Project Maaschappelijk Functioneren Politie, achtergrondstudie 1, 1995, december, Dordrecht.

Tak, P.J.P., 'De vervolging van strafbare feiten in Engeland en Wales vơớr en ná 1986', Delikt en Delinkwent, 1988, afl. 1, p. 24-39. 
Tak, P.J.P., J.A.W. Lensing, Het wooronderzoek rechtsvergelijkend onderzocht, 1990, Gouda Quint BV, Arnhem.

Tarling, Roger, 'Interdependence and the Crown Prosecution Service', in: J.E. Hall Williams, The Role of the Prosecutor, 1988, Avebury, Aldershot, p. 43-50.

Taylor, A.J.P., English History 1914-1945, 1970, Penguin Books, Harmondsworth.

Taylor, Stan, 'The Scarman Report and explanations of riots', in: John Benyon, (ed), Scarman and After, 1984, Pergamon Press, Oxford.

The Times, 1993, 20 May, p. 1, 3.

Timmons, John, 'The Crown Prosecution Service in Practice', The Criminal Law Review, 1986, p. 28-32.

Traa, Van, Inzake Opsporing, 'Enquêtecommissie Opsporingsmethoden', 1996, SDU Uitgevers, 's-Gravenhage.

Tregilgas-Davey, Marcus, 'Miscarriages of Justice within the English legal system', New Law Journal, 1991, May 17, p. 668-670, 715-717.

Tulder, F.P. van, 'Naar een meer doelmatige politie?', in: Cachet, A. en U. Rosenthal, Reorganisatie van de palitie: een tussenbalans, 1992, Gouda Quint Bv, Arnhem, p. 70-80.

Unofficial Committee of Enquiry, The Death of Blair Peach, NCCL, 1980.

Versteden, C.J.N. en T. Renes, Provincierecht, 1994, W.E.J. Tjeenk Willink, Zwolle.

Vijver, C.D. van der, Geweldgebruik door de politie, 1980, Tjeenk Willink, Zwolle.

Vijver, C.D. van dier, De Burger en de Zin van Strafrecht, 1993, Koninklijke Vermande, Lelystad.

Vries, J. de en T.C. de Groot, 'Parlementaire enquêtes en quasi-enquêtes in de jaren tachtig', Beleid \& Maatschappij, 1991, 1, januari/februari, jirg. XVIII.

Vrugt, M. van de, Aengaende Criminele Saken, 1992, Kluwer, Deventer. 
Wade, Sir William, Administrative Law, 1988, Clarendon Press, Oxford.

Wadham, John, 'Unravelling miscarriages of Justice', New Law Journal, 1993, Nowember 19, p. 1650-1651.

Walker, Clive and Keir Starmer (ed.), Justice in Error, 1993, Blackstone Press Limited, London.

Walker, Clive, 'Introduction', in: Walker, Clive en Keir Starmer, Justice in Error, 1993, Blackstone Press Limited, London, p. 1-16.

Wells, Celia, 'The Royal Commission on Criminal Justice: A Room Without a View', in: McConville, Mike en Lee Bridges, Criminal Justice in Crisis, 1994, Edward Elgar, Hants, p. 51-58.

West, Ron, 'Police superintendents and the prosecution of offences', in: John Benyon and Colin Bourn, The Police: Powers, Procedures and Proprieties, 1986, Pergamon Press, Oxford, p. 224-229.

Whitaker, Ben, The Police in Saciety, 1979, Eyre Methuen, London.

White Paper 'Police Complaints and Discipline Procedures', 1983, HMSO, Cmnd. 9072, London.

White, Robin C.A., 'A public prosecution service for England and Wales', in: Benyon, John, and Colin Bourn, The Police: Powers, Procedures and Proprieties, 1986, Pergamon Press, Oxford, p. 196-210.

Wilders, O.L.A., 'Een huwelijk maakt nog geen relatie', Het Tijdschrift voor de Politie, 1994, maart, nr. 3, p. 12-15.

Williams, Glanville, 'Letting off the guilty and prosecuting the innocent', The Criminal Law Review, 1985, p. 115-122.

Wilson, J.Q., Varieties of Police Behawiour, 1968, Harvard University Press, Cambridge, Mass.

Wilson, James Q., Thinking about Crime, 1985, revised edition, Vintage Books, New York.

Wood, John, 'Relations with the police and the public, and with overseas police and judicial authorities", in: J.E. Hall Williams, The role of the prosecutor, 1988, Avebury, Aldershot, p.19-26. 
Working Group for England and Wales, Report: The handling of complaints against the police, 1974, HMSO, London.

Zander, Michael, "Police and Criminal Evidence Bill I-VIII, The Amendments I-II', in: New Law Review, 1983, March 4, 11, 18, 25, April 8, 15, 22, 29, July 22, 29.

Zander, Michael, The Police And Criminal Evidence Act 1984, 1985, Sweet \& Maxwell, London.

Zander, Michael, Cases and Materials on the English Legal System, 1988 (fifth edition), Weidenfeld and Nicolson, London.

Zander, Michael, 'What the Annual Statistics Tell Us About Pleas and Acquittals', The Criminal Law Review, 1991, p. 252-258.

Zander, Michael, 'Where the critics got it wrong', New Law Journal, 1993, September 24 , p. 1338, 1339, 1341, en New Law Journal, 1993, October 1, p. 1364-1366.

Zuckerman, A.A.S., 'Miscarriage of Justice and Judicial Responsibility', The Criminal Law Review, 1991, p. 492-500.

Zuckerman, A.A.S., "Miscarriage of Justice - A Root Treatment", Criminal Law Review, 1992, p. 323-345. 


\section{Curriculum Vitae}

Cornée Royakkers werd geboren in Tilburg op 5 oktober 1963. Na het behalen van het VWO-diploma aan het Bisschoppelijk College te Echt in 1982 ging zij rechten studeren aan de Rijksuniversiteit Limburg (recentelijk omgedoopt tot Universiteit Maastricht). Tijdens haar studie verbleef zij gedurende een jaar in Leuven als vrij student Criminologie aan de Katholieke Universiteit aldaar. Na het afsluiten van de studie rechten in 1987 volgde zij een éénjarige postdoctorale opleiding criminologie aan het Institute of Criminology van de University of Cambridge. In 1988 werd zij aio en enkele jaren later docente bij de vakgroep strafrecht en criminologie van de Faculteit der Rechtsgeleerdheid van de Rijksuriversiteit Limburg. Sinds september 1995 werkt zij als juridisch medewerkster op een advocatenkantoor in Den Haag. 